\title{
Phase II Historical Investigations at Justiceberg Reservoir, Garza and Kent Counties, Texas
}

Martha Doty Freeman

Prewitt and Associates, Inc.

Douglas K. Boyd

Prewitt and Associates, Inc.

Follow this and additional works at: https://scholarworks.sfasu.edu/ita

Part of the American Material Culture Commons, Archaeological Anthropology Commons, Environmental Studies Commons, Other American Studies Commons, Other Arts and Humanities Commons, Other History of Art, Architecture, and Archaeology Commons, and the United States History Commons

Tell us how this article helped you.

This Article is brought to you for free and open access by the Center for Regional Heritage Research at SFA ScholarWorks. It has been accepted for inclusion in Index of Texas Archaeology: Open Access Gray Literature from the Lone Star State by an authorized editor of SFA ScholarWorks. For more information, please contact cdsscholarworks@sfasu.edu. 


\section{Phase II Historical Investigations at Justiceberg Reservoir, Garza and Kent}

Counties, Texas

\section{Creative Commons License}

\section{(c) (i) $(9)$}

This work is licensed under a Creative Commons Attribution-NonCommercial-No Derivative Works 4.0 International License. 


\section{PHASE II HISTORICAL INVESTIGATIONS AT JUSTICEBURG RESERVOIR, \\ GARZA AND KENT COUNTIES, TEXAS}

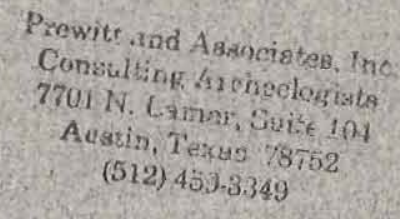

by

Martha Doty Freeman

and

Douglas K. Boyd

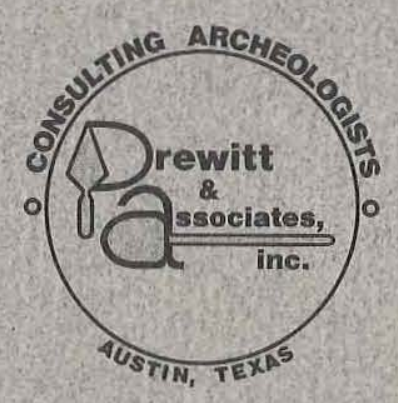


PHASE II HISTORICAL INVESTIGATIONS AT JUSTICEBURG RESERVOIR, GARZA AND KENT COUNTIES, TEXAS

by

\author{
Martha Doty Freeman \\ and
}

Douglas K. Boyd

CO-PRINCIPAL INVESTIGATORS: Elton R. Prewitt and J. Michael Quigg

REPORTS OF INVESTIGATIONS, NUMBER 72

\author{
Submitted to \\ City of Lubbock \\ Lubbock, Texas \\ by \\ Prewitt and Associates, Inc. \\ Consulting Archeologists \\ Austin, Texas
}

September 1990

TEXAS ANTIQUITIES COMMITTEE PERMIT NO. 712 
Series Technical Editor: Linda Nance Foster 
TABLE OF CONTENTS

ABSTRACT . . . . . . . . . . . . . . . . . . . . . . viii

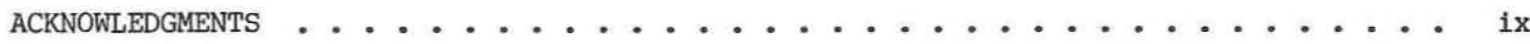

CHAPTER 1: INTRODUCTION

Martha Doty Freeman and Douglas K. Boyd .............. 1

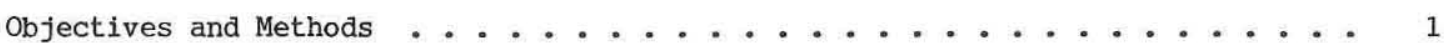

Development of Historic Contexts ....................... 2

CHAPTER 2: NATURAL RESOURCES EXPLOITATION AND DEVELOPMENT:

BUFFALO HUNTING ON THE ROLLING PLAINS, 1874-1879

Martha Doty Freeman ................ . . 7

Natural Resources in Texas: Perceptions of Superabundance . . . . . . . 7

Uses and Treatments of Natural Resources . . . . . . . . . . . . . 14

Effects of Uncontrolled Exploitation . . . . . . . . . . . . 16

Buffalo as a Superabundant Natural Resource . . . . . . . . . . . 17

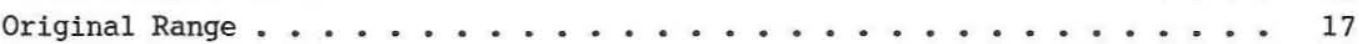

Impacts on the Original Range ....................... 18

Post-1860 Systematic Exploitation of the Southern Buffalo Herd . . . . . 21

Development of Markets for the Buffalo Product . . . . . . . . . . . 25

Construction of Railroads . . . . . . . . . . . . . . 25

Technological Developments and Inventions . . . . . . . . . 25

Demand for the Buffalo Product: Furs, Hide, and Meat . . . . . . . 27

Buffalo Hunting as a Business: Structure of the Trade . . . . . . . . 27

Central Markets .................. 30

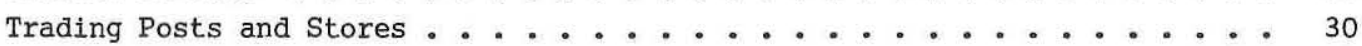

Hunting Outfits and Camps ................ 32

Acquisition of the Product ................... 42

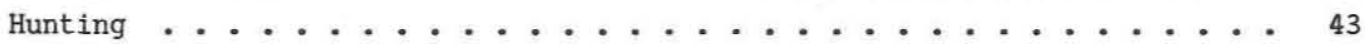

Skinning ......................... . . . 44 44

Folding and loading ................... . . . . 44

Pegging and Drying ..................... 44

Organizing and Classifying ................ 45

Folding and Stacking .................. . . 4 45

Butchering, Curing, Smoking ................. 45

Transportation to Markets/Freighting . . . . . . . . . . 4 46

Livestock Feeding and Bone Collecting . . . . . . . . . . . . 47

Buffalo Hunting on the Rolling Plains, 1874-1879 . . . . . . . . . . 47

CHAPTER 3: AGRICULTURE IN TEXAS:

RANCHING ON THE WESTERN ROLLING PLAINS, 1877-1945

Martha Doty Freeman ............... 51

Overview of Crop and Livestock Production . . . . . . . . . . . . 51 
Sheep and Cattle Ranching in Texas: A Summary of Scope and Trends . . . . . 60 Sheep Raising .. . . . . . . . . . . . . . . . 61

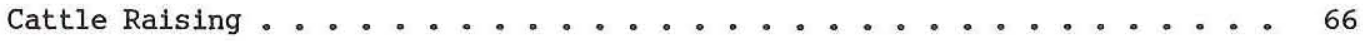
Sheep and Cattle Ranching: Some Common Issues . . . . . . . . . 80

Ranching on the Western Rolling Plains, 1877-1945 ............ 82 Open-range Ranching, 1877-ca. 1890 .............. 83 Closed-range Ranching on the Western Rolling Plains, ca. 1890-1945 . . . . 96

CHAPTER 4: SITE INVESTIGATIONS

Martha Doty Freeman and Douglas K. Boyd ............ 99

First-priority Sites .................... . 99

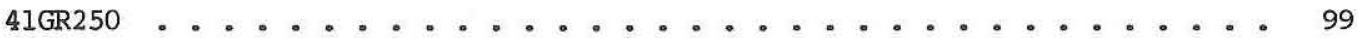

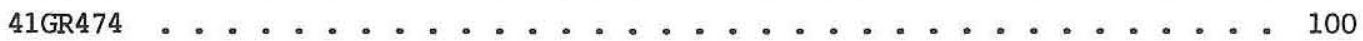

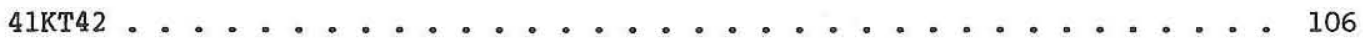

Second-priority Sites ...................... 111

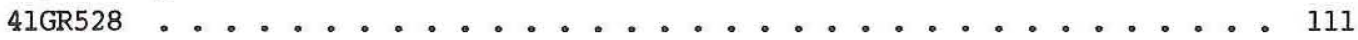

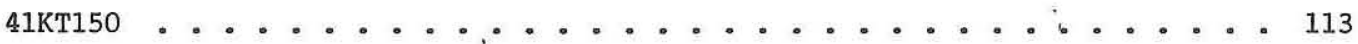

CHAPTER 5: OUTLINE OF PROPERTY TYPES AND NATIONAL REGISTER ASSESSMENTS

Martha Doty Freeman ................ 115

Buffalo Hunting Camps on the Rolling Plains .............. 115

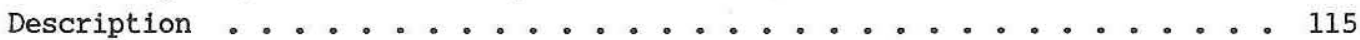

Significance ........................ 116

Registration Requirements ................ 117

National Register Assessment: 41GR528 . . . . . . . . . . . . 118

Ranching Sites on the Western Rolling Plains . . . . . . . . . . . 119

Description ...................... 119

Significance . . . . . . . . . . . . . . . . . . 120

Registration Requirements ................... 121

National Register Assessment: 41GR13 . . . . . . . . . . . 123

National Register Assessment: 41GR203 and 41GR470 ........... 124

National Register Assessment: 41GR250 . . . . . . . . . . . . 124

National Register Assessment: 41GR263 . . . . . . . . . . . 125

National Register Assessment: 41GR331 . . . . . . . . . . . 126

National Register Assessment: 41GR392 . . . . . . . . . . . 127

National Register Assessment: 41GR443 ............. 128

National Register Assessment: 41GR474 . . . . . . . . . . 129

National Register Assessment: 4lKT42 . . . . . . . . . . . . 130

National Register Assessment: 41KT84 ............... 131

REFERENCES CITED ............................ . . . . . . . . . . . .

APPENDIX: Artifact Analysis

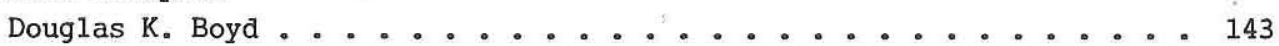

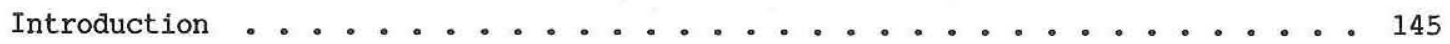

Historic Artifacts from Prehistoric Sites . . . . . . . . . . . . . 145 
Historic Site 41GR474 . . . . . . . . . . . . . . . . 145

Early Occupation Artifacts . . . . . . . . . . . . . 146

Mixed Occupation Artifacts . . . . . . . . . . . . . 146

Late Occupation Artifacts . . . . . . . . . . . . . 147

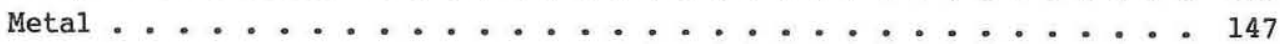

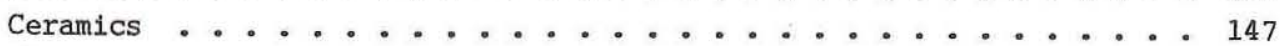

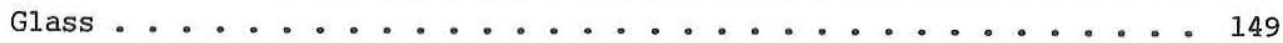

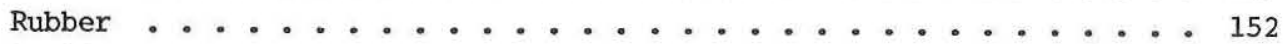

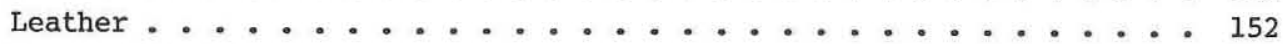

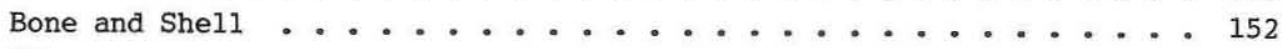

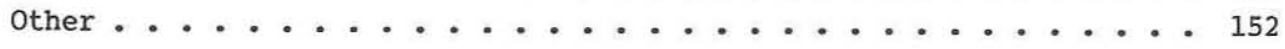

Historic Site $41 \mathrm{GR} 428$. . . . . . . . . . . . . . . 152

Historic Site $41 \mathrm{KT} 52$. . . . . . . . . . . . . . . 153

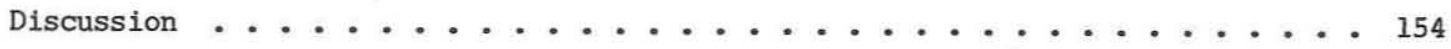

References Cited ...................... . . 156 
1. Historic ranges of the American bison . . . . . . . . . . . . 19

2. Historic features associated with the buffalo trade in the Southern Plains . . 22

3. Ranches on the western Rolling Plains, from $1877 \ldots \ldots 3$

4. Map of historic component of $41 \mathrm{GR} 474$. . . . . . . . . . . . . 102

5. Generalized profile of the dugout excavation, 41GR474 . . . . . . . . 103

6. Floor plan and roof plan of the Jeff Justice House at site 4lGR474 . . . . 105

7. Map of historic site area, 41KT42 . . . . . . . . . . . . . 107

8. Photograph of site $41 \mathrm{KT} 42$. . . . . . . . . . . . . . . . 108

9. Map of house structure, 41KT42 . . . . . . . . . . . . . . 109 
1. Natural resources exploitation, development, and conservation: selected resources and associated property types . . . . . . . . . . 8

2. Sites associated with natural resource exploitation and development . . . . 9

3. Buffalo hunting on the Rolling Plains,

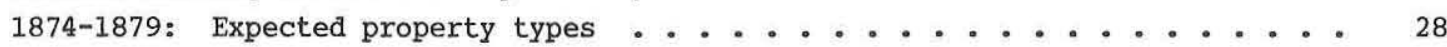

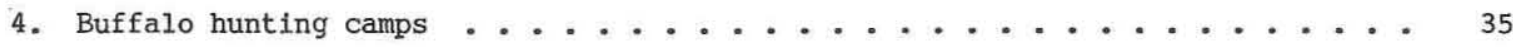

5. Sites associated with agriculture . . . . . . . . . . . . . 52

6. West Texas property types: dugouts . . . . . . . . . . . . 72

7. Selected ranches on the western Rolling Plains . . . . . . . . . . . 84

8. Provenience of historic artifacts ................... . . . . . . . . .

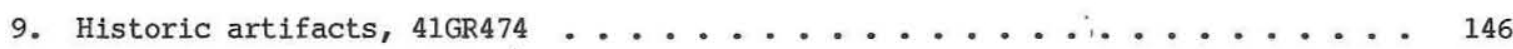

10. Metal artifacts recovered from trash fill in the dugout, 41GR474 . . . . . 148

11. Ceramics recovered from trash fill in the dugout, 4lGR474 . . . . . . . 149

12. Attributes of bottles collected from the surface, 41GR474 . . . . . . . 150

13. Glass artifacts recovered from trash fill in the dugout, 41GR474 . . . . . 151

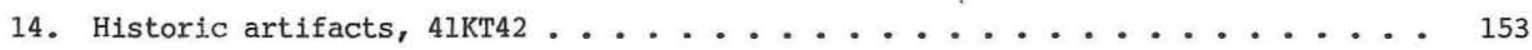

15. Functional classification of historic artifacts . . . . . . . . . 155 
Phase II cultural resources investigations at the proposed Justiceburg Reservoir in Garza and Kent counties, Texas, conducted in 1988-1989 included work at four historic sites, the recording of a previously unrecorded historic site, and development of two National Register contexts. This report documents the archeological work at the sites and presents data that resulted from in-depth research concerning the history of the use and development of these sites. In addition, the report presents two historic contexts which were developed in order to provide tools for the assessment of sites within the project area and, at the same time, to present information that could be used in future archeological and architectural surveys in the Southern Plains area. As a result of the development of the contexts and reexamination of 12 historic sites to which the registration requirements associated with the contexts could be applied, 7 of the sites were found to be eligible for listing on the National Register of Historic Places. 
The historical research necessary to complete Phase II of the Justiceburg Reservoir cultural resources study was greatly facilitated and enhanced by the support and encouragement of numerous private individuals and employees of public institutions. In the project area, Mike Gilliland, Engineer Assistant of the City of Lubbock's Water Utility Department, provided the names of local residents who were knowledgeable about local history such as Mr. and Mrs. Ernest Ford of the Polar community. In Justiceburg, Mr. and Mrs. Mason Justice, Mrs. Pearl Nance, and William Wayne Williams agreed to be interviewed, while Riley Miller spent the great part of a day driving the historian to ranch sites in the area and talking knowledgeably about local history. Nearby, Mr. Miller's aunt, Mrs. Edna Miller, generously shared information she had accumulated over many decades as one of the area's premier historians.

In Post, the historian was directed to Mrs. A. C. Surman, whose collection of oral history tapes provided valuable local history data. Mrs. Maudie Smith supplemented information provided by $\mathrm{Mr}$. and Mrs. Justice about the Justice Ranch, while Mrs. Mary Alice Headstream of Abilene assisted in pinpointing the location of a previously unrecorded historic dugout site.

My thanks go to all the individuals who generously shared information they had acquired during many years of research and interviewing. Institutions which also cooperated fully with the project effort include the Panhandle-Plains Historical Museum in Canyon, whose librarian, Claire R. Kuehn, copied and forwarded several important interviews; and the Southwest Collection at Texas Tech University in Lubbock. There, David Murrah, who enjoys a well-deserved reputation as one of the State's foremost authorities on ranching, not only directed the historian to appropriate primary and secondary materials but also added his personal and very pertinent observations about the ranching industry in the project area. In Snyder, the staff of the Scurry County Museum opened their files concerning buffalo hunting and hunters. Finally, Dwayne Jones at the Texas Historical Commission graciously guided the historian through the process of developing two National Register contexts, offering critiques, suggestions, and encouragement. His support made a potentially daunting experience into an opportunity to learn skills necessary to comply with National Park Service guidelines while completing National Register contexts and assessments.

My thanks also go to the personnel at Prewitt and Associates, Inc., whose usual careful reading, textual editing, and figure drafting added immeasurably to the accuracy and internal logic of the final report.

Martha Doty Freeman 



\section{INTRODUCTION}

by Martha Doty Freeman and Douglas K. Boyd

The Phase II cultural resources investigations at Justiceburg Reservoir consisted of three main avenues of research: geoarcheological, archeological, and historical. This report deals exclusively with the historic aspects of the Phase II study; it describes the objectives, methods, and results of the historic investigations. A separate report (Boyd et al. 1990) describes the Phase II geoarcheological and aboriginal site investigations and presents environmental and archeological background information.

This report consists of five chapters and one appendix. This chapter presents the objectives and methods of the historic investigations and discusses the development of two regional historic contexts. Chapter 2 presents the historic context relating to buffalo hunting, and Chapter 3 presents the context relating to ranching. Both contexts were established to aid in evaluating the significance of historic resources in the Rolling Plains. Chapter 4 describes the archival/informant research and archeological investigations of individual sites in the Justiceburg Reservoir project area. Chapter 5 provides outlines of property types and National Register assessments of specific sites based on the historic contexts discussed in Chapters 2 and 3 . The appendix to this volume describes the historic artifacts recovered during the site investigations.

\section{Objectives and Methods}

Documentation of the historical development of the region and the historic resources within the project area have been the primary goals during both phases of the cultural resources investigations. The Phase I work produced a preliminary synthesis detailing the historical background of the region and identified 30 historic sites in the project area (Freeman 1989a, 1989b). The Phase II work consisted of two main avenues of research, both oriented toward providing data for assessing the significance of the resources. The first task involved archival and informant research conducted to develop historic contexts (as defined by the National Park Service for the state planning programs). These contexts were to serve as the frameworks for evaluating site significance according to the criteria of the National Register of Historic Places. The second task involved site-specific research related to three sites in the project area--41GR250, 41GR474, and 41KT42--along with archeological testing at the latter two sites. These sites (designated first-priority sites) were selected through consultation and agreement among the managing entities (the U.S. Army Corps of Engineers, the Texas Historical Commission, and Freese and Nichols, Inc.), and the investigations were designed to obtain data to assess site significance and integrity.

Additional investigations at two sites (designated second-priority sites) are also reported in this volume. One historic ranch line camp located adjacent to the project area, 41KT150, was discovered through informant research. Initial documentation of this site was completed, and it is reported here for the first time. The second site, 41GR528, is a probable buffalo hunters camp/grave which was revisited and reevaluated during the Phase II investigations. 
Archival research conducted during Phase II was directed toward obtaining both sitespecific data and data of a regional scope that could be used to develop historic contexts. Site-specific research consisted of the collection of numerous oral history interviews with knowledgeable local informants, the use of oral history interviews previously collected by researchers and interested local residents, legal research that amplified and completed information presented in the Phase I report, and use of archival materials in several regional repositories. Particular attention was paid to documents available in the Panhandle-Plains Historical Museum in Canyon, the Southwest Collection at Texas Tech University in Lubbock, and the Barker Texas History Center at The University of Texas at Austin.

Acquisition of data used in developing two historic contexts also occurred on sitespecific and regional levels. Sufficient data were acquired on comparable sites outside the project area and the Rolling Plains region so that logical geographical boundaries for the contexts could be developed, while general information for the development of the historic contexts also was collected. Repositories used during both tasks included the Panhandle-Plains Historical Museum in Canyon, the Southwest Collection at Texas Tech University, the Barker Texas History Center at The University of Texas at Austin, and the National Register files at the Texas Historical Commission in Austin.

Archeological fieldwork at the historic sites consisted of mapping, surface collecting, and test excavations. These tasks were conducted following the standard archeological methods described for prehistoric sites in the companion report on geoarcheological and aboriginal site investigations (Boyd et al. 1990). Site mapping focused on historic structural remains and their associated occupational debris, but site-topography was also documented. Surface collections, when appropriate, were directed toward obtaining diagnostic artifacts which would provide useful data for interpreting site function and chronology. Subsurface hand excavations were conducted to determine the nature and integrity of the structural remains, i.e., a dugout at 41 GR474 and a rock house foundation at 41 KT 42 . The details of the archeological investigations are presented under the appropriate site discussions in Chapter 4. A descriptive/functional analysis of the artifacts recovered during these investigations is presented in the appendix to this report.

\section{Development of Historic Contexts}

Phase I investigations related to the Justiceburg Reservoir project in Kent and Garza counties, Texas, resulted in the identification of 84 historic period nonaboriginal properties, the development of a regional history, and preliminary assessments of the National Register eligibility of each site. Subsequently, in response to requirements generated by the National Park Service, the Texas Historical Commission requested that the contractor identify National Register contexts appropriate to the buffalo hunting- and ranchingrelated cultural resources present in the project area and develop texts and present data in the format presently required by the Secretary of the Interior.

The Secretary has determined that "decisions about the identification, evaluation, registration and treatment of historic properties are most reliably made when the relationship of individual properties to other similar properties is understood." In order to define such relationships, general information about specific topics must be collected and analyzed. The information is then organized according to three criteria: (1) a cultural 
theme; (2) a geographical area; and (3) a chronological period. "Contexts describe the significant broad patterns of development in an area that may be represented by historic properties. The development of historic contexts is the foundation for decisions about identification, registration and treatment of historic properties" (U.S. Department of the Interior $1983: 44,717)$.

Because the concept of National Register contexts was a new one to the contractor and to most personnel at Freese and Nichols, Inc., and to the Texas Historical Commission, the Project Historian initiated a series of discussions with Freese and Nichols and Commission staff members. During these discussions, several contexts were suggested and either modified or rejected. Simultaneously, the Texas Historical Commission formed two committees to address the issue of National Register contexts for the State. The first of these committees focused on context development for sites in Northeast Texas that were primarily archeological in nature; the second focused on the identification of National Register contexts for historic period properties which could be applied to all parts of the State and encompassed both standing structures and archeological sites.

The work of the second committee, which began in August 1988, eventually resulted in the identification of nine thematic contexts, each of which included as many as eight subcontexts. A decision then was made to select those contexts that seemed to be most appropriate to the sites and property types that had been inventoried during the Justiceburg Reservoir project and, with the approval of Freese and Nichols, Inc. and Texas Historical Commission staff members, to develop them as fully as time and budgets would allow.

An examination of the contexts suggested by the Texas Historical Commission revealed that the general themes of (1) Agriculture and (2) Natural Resources Exploitation and Development best explained the historic sites selected for examination during Phase II of the Justiceburg Reservoir project. Subsequently, sufficient historic research was completed not only to define the appropriate theme but also to determine the most logical geographical and chronological boundaries, two criteria necessary for the assessment of any cultural property.

One purpose of developing historic contexts is "to place historic properties within the context of the broad patterns of history that created them, and to place any one example within a larger group of similar properties" (Maryland Historical Trust 1987:1). Because of these requirements and expectations, and because the Phase II Justiceburg Reservoir project represented one of the first such efforts in the State, a relatively broad approach to context development was taken. One purpose of such an approach was to create contexts that could be applied to other similar properties in West Texas. Also, it was expected that with the presentation of relatively complete background information, other researchers would find it easier to modify, correct, and amplify the contexts based on their work with similar properties in other regions of the State.

The two historic contexts presented in this volume--Natural Resource Exploitation and Development: Buffalo Hunting on the Rolling Plains, 1874-1879, and Agriculture in Texas: Ranching on the Western Rolling Plains, 1877-1945--represent an initial effort to develop research tools that can be used to assess the significance of most of the historic sites within the project area. It is hoped that they are sufficiently broad in scope to allow their application to similar historic sites outside of the Justiceburg Reservoir project area and that future projects will result in their refinement. 


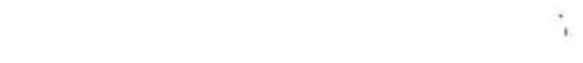


Come all you jolly fellows and listen to my song, There are not many verses, it will not detain you long; It's concerning some young fellows who did agree to go And spend one summer pleasantly on the range of the buffalo.

It happened in Jacksboro in the spring of seventy-three, A man by the name of Crego came stepping up to me, Saying, "How do you do, young fellow, and how would you like to go And spend one summer pleasantly on the range of the buffalo?"

"It's me being out of employment," this to Crego I did say, "This going out on the buffalo range depends upon the pay. But if you will pay good wages and transportation too, I think, sir, I will go with you to the range of the buffalo."

"Yes, I will pay good wages, give transportation too, Provided you will go with me and stay the summer through; But if you should grow homesick, come back to Jacksboro, I won't pay transportation from the range of the buffalo:" It's now our outfit was complete--seven able-bodied men, With navy six and needle gun--our troubles did begin; Our way it was a pleasant one, the route we had to go, Until we crossed Pease River, on the range of the buffalo.

It's now we've crossed Pease River, our troubles have begun. The first damned tail I went to rip, Christ! how I cut my thumb! While skinning the damned old stinkers our lives wasn't a show, For the Indians watched to pick us off while skinning the buffalo.

He fed us on such sorry chuck I wished myself most dead, It was old jerked beef, croton coffee, and sour bread. Pease River's as salty as hell fire, the water I could never go,-0 God! I wished I had never come to the range of the buffalo.

Our meat it was buffalo hump and iron wedge bread, And all we had to sleep on was a buffalo robe for a bed; The fleas and gray-backs worked on us, 0 boys, it was not slow, I'll tell you there's no worse hell on earth than the range of the buffalo.

Our hearts was cased with buffalo hocks, our souls were cased with steel, And the hardships of that summer would nearly make us reel. While skinning the damned old stinkers our lives they had no show. For the Indians waited to pick us off on the hills of Mexico.

The season being near over, old Crego he did say The crowd had been extravagant, was in debt to him that day,-We coaxed him and we begged him and still it was no go,-We left old Crego's bones to bleach on the range of the buffalo.

Oh, it's now we've crossed Pease River and homeward we are bound, No more in that hell-fired country shall ever we be found. Go home to our wives and sweethearts, tell others not to go, For God's forsaken the buffalo range and the damned old buffalo.

FROM: Cowboy Songs and Other Frontier Ballads (Lomax 1916:158-161). 


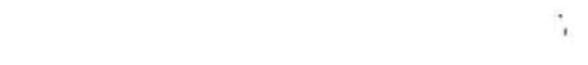


CHAPTER 2

NATURAL RESOURCES EXPLOITATION AND DEVELOPMENT:

BUFFALO HUNTING ON THE ROLLING PLAINS, 1874-1879

by Martha Doty Freeman

At the conclusion of the great buffalo hunt in 1887, William T. Hornaday (1971:487) wrote: "Perhaps the most gigantic task ever undertaken on [the North American] continent in the line of game-slaughter was the extermination of the bison in the great pasture region by the hide-hunters. Probably the brilliant rapidity and success with which that lofty undertaking was accomplished was a matter of surprise even to those who participated in it." Beginning in the second half of the nineteenth century throughout the High Plains and Southern Plains areas and continuing in Texas until the late 1870s, the systematic slaughter of buffalo herds was a highly structured, very profitable business, the success of which was dependent on the efficient acquisition of a product and its distribution through markets.

The success of the hunt was also dependent on the availability of the buffalo, at one time the most superabundant natural resource on the North American continent. Willingness to exploit this resource was tied in turn to beliefs in its inexhaustibility, to settlers' rights to exploit the resource, and to the development of transportation and economic systems and of specific inventions which made the eradication of the resource profitable.

Natural Resources in Texas: Perceptions of Superabundance

Exploitation of natural resources has been a fundamental underpinning of economic and social life in Texas during the historic period since the seventeenth century. The presence of seemingly inexhaustible resources, whether minerals, timber, clay, stone, wildlife (both aquatic and terrestrial), water, soils, or grasses, has in turn resulted in a plethora of historic sites and structures which facilitated the extraction of the resources on the one hand and whose construction was made possible by the marketing of those resources on the other hand (Tables 1 and 2). In West Texas, the towns of Shafter (N.R. 1976) in Presidio County and Terlingua in Brewster County resulted from the mining of silver and mercury. Construction of the Turner Home in Midland (N.R. 1988) was funded by wealth derived from the Yates Oil Field in Pecos County. In Central Texas, numerous archeological sites resulted from the harvesting of cedar trees and marketing of cedar products (e.g., 41WM575, 41WM653, and 41TV763); in East Texas, the harvesting of pine trees resulted in the construction of numerous tram lines (e.g., 41SB69) and company towns.

The richness of lignite deposits in much of East Texas found physical expression in the construction of a number of company towns in Leon and other counties during the first third of the twentieth century (41LN52, 41LN93-41LN96, 41LN108, 41LN111, 41LN114, 41LN118, and 41LN208), while exploitation of clay deposits resulted in the construction of towns such as Thurber in Erath County (N.R. 1979) and sites such as Kirbee Kiln in Montgomery County (N.R. 1973). The State's abundant surface and underground water resources contributed to the phenomenal growth of towns and cities such as Gonzales and San Antonio and resulted in the construction of power plants and dams in the late nineteenth century and in 
TABLE 1

NATURAL RESOURCES EXPLOITATION, DEVELOPMENT, AND CONSERVATION: SELECTED RESOURCES AND ASSOCIATED PROPERTY TYPES

\begin{tabular}{|c|c|c|c|c|c|}
\hline Water & Timber & Minerals & Clay & Stone & Wildlife \\
\hline $\begin{array}{l}\text { Dams } \\
\text { Acequias } \\
\text { Aqueducts } \\
\text { Generating } \\
\quad \text { plants } \\
\text { Spas } \\
\text { Hotels } \\
\text { Railroads } \\
\text { Parks }\end{array}$ & $\begin{array}{l}\text { Company towns } \\
\text { Worker housing } \\
\text { Owner housing } \\
\text { Tram lines } \\
\text { Lumberyards } \\
\text { Hotels and other } \\
\text { urban commercial } \\
\text { establishments } \\
\text { Temporary camps }\end{array}$ & $\begin{array}{l}\text { Company towns } \\
\text { Worker housing } \\
\text { Owner housing } \\
\text { Railroad spurs } \\
\text { Mine shafts } \\
\text { Mechanical equipment } \\
\text { Hotels and other } \\
\text { urban commercial } \\
\text { establishments } \\
\text { Temporary camps }\end{array}$ & $\begin{array}{l}\text { Manufacturing } \\
\quad \text { establishments } \\
\text { Railroad spurs } \\
\text { Kilns } \\
\text { Potteries } \\
\text { Housesites } \\
\text { Slave quarters }\end{array}$ & $\begin{array}{l}\text { Kilns } \\
\text { Manufacturing } \\
\quad \text { establishments } \\
\text { Worker housing } \\
\text { Owner housing }\end{array}$ & $\begin{array}{l}\text { Railroads } \\
\text { Towns } \\
\text { Commercial } \\
\quad \text { establishments/stores } \\
\text { Trader housing } \\
\text { Merchant housing } \\
\text { Hunter housing } \\
\text { Trading posts } \\
\text { Hunting camps } \\
\text { Stands } \\
\text { Smokehouses } \\
\text { Curing pits } \\
\text { Game warden cabins } \\
\text { Ranches }\end{array}$ \\
\hline
\end{tabular}


TABLE 2

SITES ASSOCIATED WITH NATURAL RESOURCE

EXPLOITATION AND DEVELOPMENT*

Natural Resource/

Site Name/Number

Location

State/National

Designation(s)

WATER

Espada Aqueduct (41BX269)

San Antonio Water Works

Pump Station No. 2

San Pedro Springs Park (41BX19)

Source of the River Archeological

District (41BX24, 41BX261, 41BX282

through 41BX292)

Hot Wells Hotel

Hot Spring (41BS24, 41BS350, 41BS440)

Krause Springs Archeological Site

(41BT78)

Hydroelectric Plant

Heinrich Ludwig Kreische House

and Brewery (41FY128)

Piedmont Springs Archeological Site

(Sulphur Springs) (41GM44)

Saffold Dam (Starcke Park Dam)
Bexar County

H.A.B.S. 1936, 1937;

R.T.H.L. 1962;

N.H.L. 1964

Bexar County ～～N.R. 1981

Bexar County

S.M. 1965; N.R. 1979

Bexar County

N.R. 1978

Bexar County

Brewster County

N.R. 1974

Burnet County

N.R. 1978

DeWitt County

N.R. 1977

Fayette County

N.R. 1975

Grimes County

N.R. 1982

Guadalupe County

N.R. 1979

*Sites and structures listed are drawn from Steely (1984) for the most part. Historic properties not listed in Steely are included because they are known by the historian and are considered to be unusually good examples of the exploitation of a specific resource.

Abbreviations used include H.A.B.S. (Historic American Buildings Survey), R.T.H.L. (Recorded Texas Historic Landmark), N.H.L. (National Historic Landmark), N.R. (National Register), C.M. (Centennial Marker), T.H.E.S.I. (Texas Historical Engineering Site Inventory), and S.M. (Texas Subject Marker). 
Table 2, continued

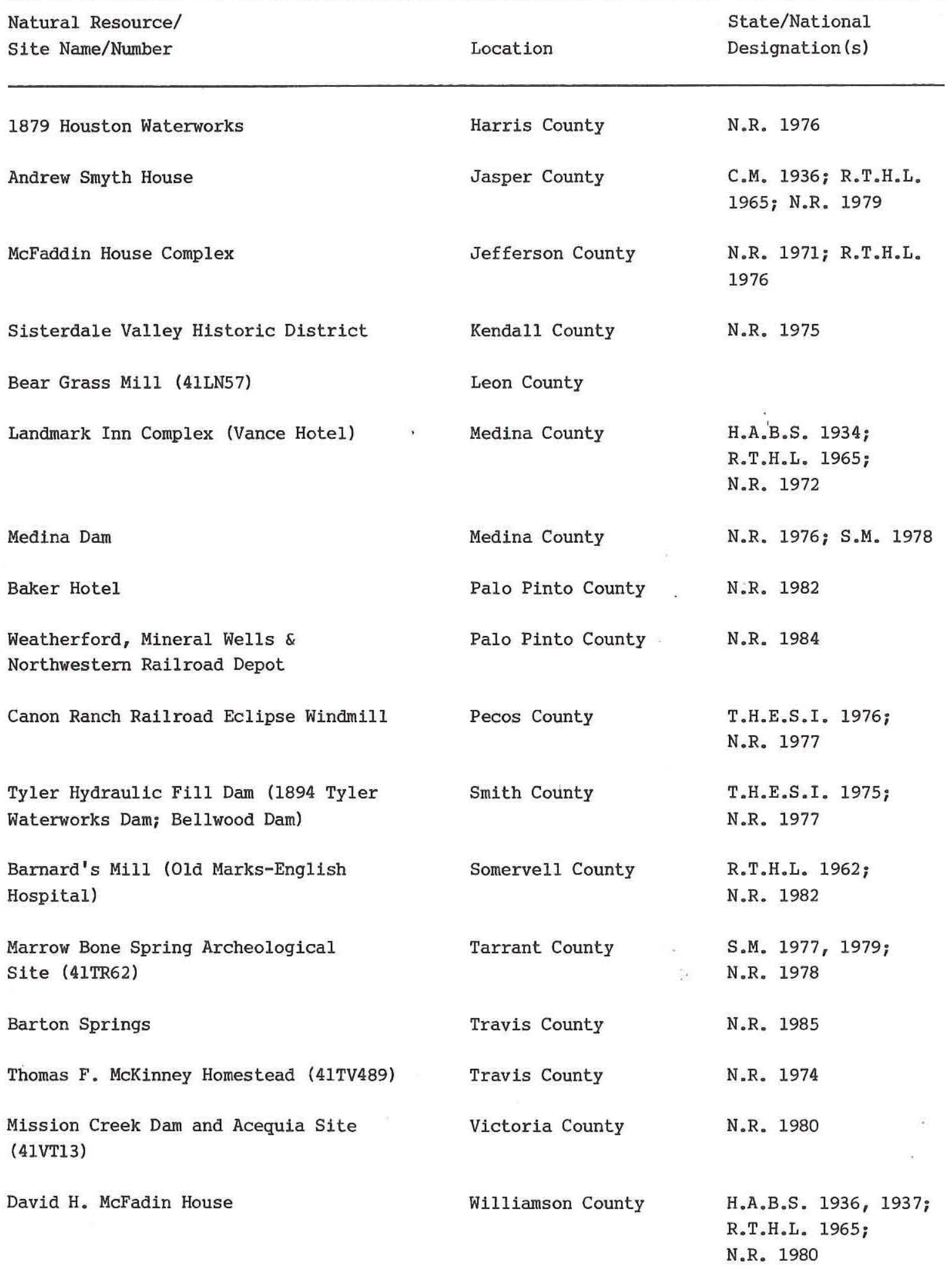


Table 2, continued

Natural Resource/

Site Name/Number

Location

State/National

Designation(s)

TIMBER

\begin{tabular}{|c|c|c|c|}
\hline J. J. Carroll House & Harris County & & N.R. 1979 \\
\hline W. T. Carter House & Harris County & & N.R. 1979 \\
\hline Andrew Smyth House & Jasper County & & $\begin{array}{l}\text { C.M. 1936; R.T.H.L. } \\
\text { 1965; N.R. } 1979\end{array}$ \\
\hline Beaumont Commercial District & Jefferson County & & N.R. 1978 \\
\hline Hinchee House & Jefferson County & ; & $\begin{array}{l}\text { N.R. } 1978 ; \text { R.T.H.L. } \\
1982\end{array}$ \\
\hline McFaddin House Complex & Jefferson County & & $\begin{array}{l}\text { N.R. } 1971 ; \text { R.T.H.L. } \\
1976\end{array}$ \\
\hline Robert Washington Sanders House & Jefferson County & & $\begin{array}{l}\text { N.R. } 1978 ; \text { R.T.H.L. } \\
1982\end{array}$ \\
\hline William H. Stark House & Orange County & & $\begin{array}{l}\text { R.T.H.L. 1976; } \\
\text { N.R. } 1976\end{array}$ \\
\hline 41SB69 (tram line) & Sabine County & & \\
\hline 41 TV763 (charcoal kiln) & Travis County & & \\
\hline $\begin{array}{l}\text { 41WM575, 41WM653 } \\
\text { (cedar harvesting camps) }\end{array}$ & Williamson County & & \\
\hline $\begin{array}{l}\text { MINERALS (oil, gas, copper, coal, } \\
\text { lignite, silver, salt, } \\
\text { helium, sulphur) }\end{array}$ & $\because$ & & \\
\hline Mariscal Mine (41BS441) & Brewster County & & N.R. 1974 \\
\hline Terlingua Historic District & Brewster County & & \\
\hline Magnolia Building (Mobil Building) & Dallas County & & $\begin{array}{l}\text { R.T.H.L. 1978; } \\
\text { N.R. } 1978\end{array}$ \\
\hline Thurber Historic District & Erath County & & S.M. 1969; N.R. 1979 \\
\hline Ada Belle Oil Wells & Hardin County & & S.M. 1971; N.R. 1980 \\
\hline Thomas Joseph Donoghue House & Harris County & & N.R. 1979 \\
\hline
\end{tabular}


Table 2, continued

Natural Resource/

Site Name/Number

Gulf Building

Ross Shaw Sterling House

(Texas White House)

El Sal del Rey Archeological District

(El Sal del Rey, La Purificacion)

(41HG22, 41HG45, 41HG52)

Beaumont Commercial District

Hinchee House

Mildred Building

Lucas Gusher (Spindletop Oil Field)

Evansville Mine (41LN52, 41LN93

through 41LN96, 41LN108, 41LN111,

4ILN114, 41LN118, 41LN208)

Lyne Taliaferro "Tol" Barret House

Oil Springs Oil Field Discovery Well

Corsicana Oil Field Discovery Well

El Paisano Hotel

Shafter Historic Mining District

Neches Saline (X41SM1 through X41SM3, X41SM33)

W. T. Waggoner Building

Daniel Waggoner Mansion (E1 Castile)
Harris County

Harris County

Hidalgo County

Jefferson County

Jefferson County

Jefferson County

Jefferson County

Leon County

Nacogdoches County

Nacogdoches County

Navarro County

Presidio County

Presidio County

Smith County

Tarrant County

Wise County
State/National

Designation(s)

N.R. 1983

S.M. 1978; N.R. 1982

R.T.H.L. 1964;

N.R. 1979

N.R. 1978

N.R. 1978; R.T.H.L. 1976

N.R. 1978

C.M. 1979; N.H.L. 1966

N.R. 1979; R.T.H.L. 1981

S.M. 1967; T.H.E.S.I. 1975; N.R. 1977

C.M. 1936; T.H.E.S.I. 1975; N.R. 1977

N.R. 1978; R.T.H.L. 1979

N.R. 1976

N.R. 1979

R.T.H.L. 1962;

N.R. 1974 
Table 2, continued

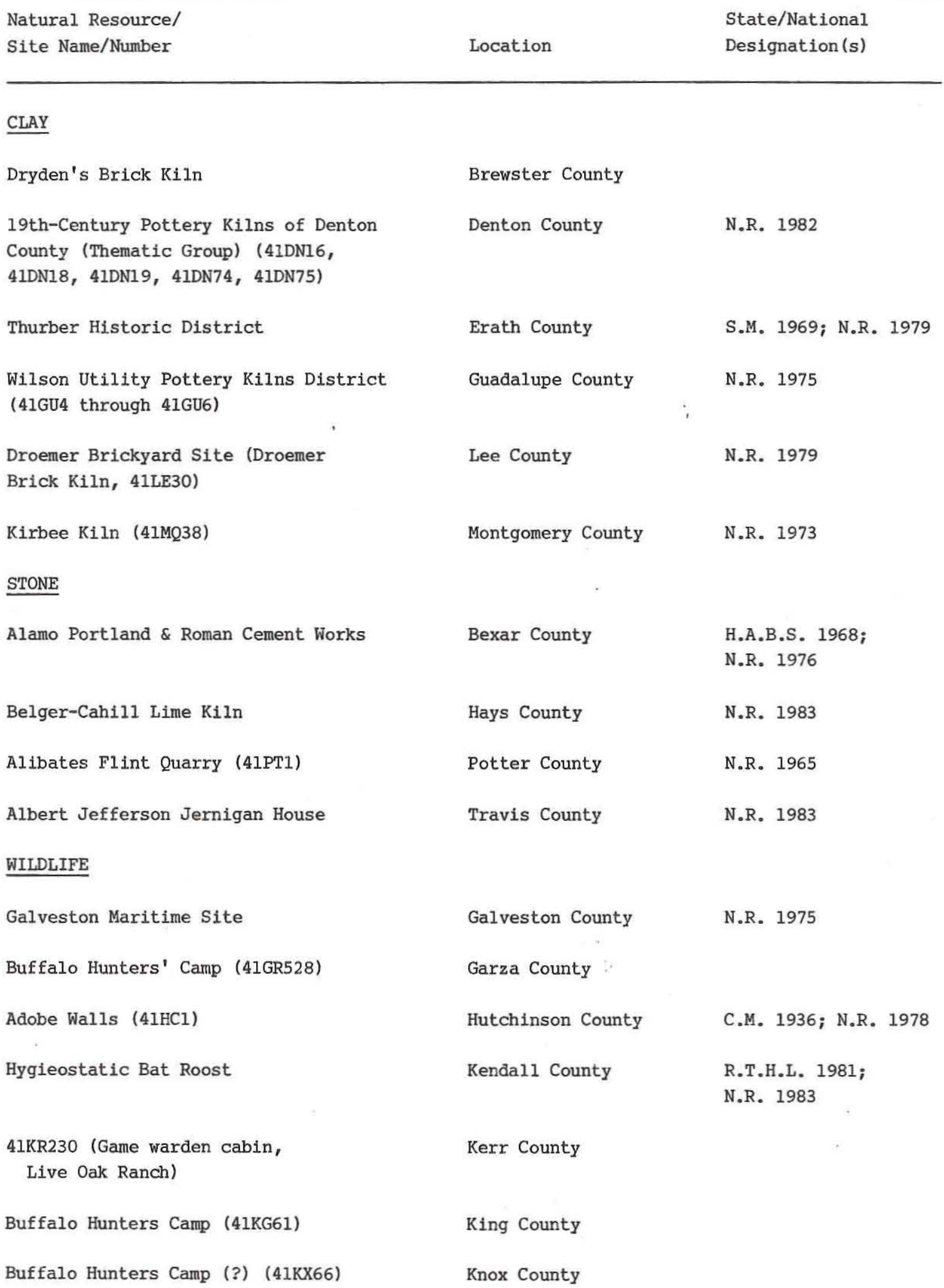


Table 2, continued

Natural Resource/

Site Name/Number

Location

State/National

Designation(s)

Torrey's Trading House No. 2

McLennan County

C.M. 1936; S.M. 1966;

(41ML45)

N.R. 1975

Fort Griffin (41SF4)

Shackelford County

C.M. 1936; N.R. 1971

rural and urban sites as diverse as the Bear Grass Mill in Leon County (41LN57), Kreische's Brewery in Fayette County (N.R. 1975), Espada Aqueduct (N.H.L.) and Hot Wells Hotel in Bexar County, and the Landmark Inn Complex in Medina County (N.R. 1972). While these sites are quite different from one another in age, complexity, and location, they all depended upon the identification, extraction, and use of a specific natural resource.

Interest in exploiting a specific resource often was related directly to the perception that the resource was superabundant, if not inexhaustible, and nowhere was this attitude more prevalent than as it related to wildlife in Texas. Travelers throughout the area frequently were amazed by the "biological storm." As Doughty wrote in 1983, social animals associating in herds--especially bison, mustangs, antelope, and deer--impressed residents and visitors by their numbers. The animals were perceived of as being "integral and important elements in the blogeography of the state." In addition, they were "living witness to the natural wealth of the region under a benign climate. They were proof that here was the best of all possible worlds" (Doughty 1983:58).

To a certain extent, the perception of superabundance was an accurate one. Texas is at the biological crossroads of North America. Thus, even taking into account an Edenic literary tradition of exaggerating numbers and varieties of North American species, Texas historically must have been characterized by a profusion of wildlife difficult to imagine in the twentieth century. For 200 years, explorers, naturalists, and settlers remarked on the millions of bison and the passenger pigeons whose numbers were so great that they could not be calculated (Doughty 1983:155). The prairies of South Texas contained large droves of wild horses, and the coast was so filled with waterbirds that in the mid 1840s Ferdinand Roemer described the bay in the vicinity of Morgan's Point as being "completely blackened." He complained that "a confused noise, composed of a thousand-fold cackling and screeching rose up from the water as if coming from a huge poultry yard, and this continued unabated throughout the night" (Roemer 1935:55-56). Deer occurred everywhere, and in some places "jackrabbits were supposedly so approachable that settlers killed them by simply heaving a stone or clubbing them with a stick" (Doughty 1983:155).

Uses and Treatments of Natural Resources

The image of superabundance, coupled with the extent to which the image was in fact real, has resulted in an active involvement with native flora and fauna throughout the history of Texas. Settlers believed that they should be free to exploit the State's 
"biotic treasure trove," and the area became regarded as a "vast storehouse of usable wildlife" (Doughty 1983:9, 95, 217). This freedom to exploit the superabundance was avidly exercised well into the twentieth century and was expressed in a number of ways.

First, settlers used wildlife as a primary food source. They depended upon native animals for food, clothing, and furnishings for their homes. Indeed, wildlife was essential to early settlers' livelihoods prior to the establishment of cultivated crops or the availability of bred stock. It was a staple for explorers, travelers, traders, and military personnel, and it served as a food source when droughts or floods destroyed cultivated crops (Doughty 1983:23, 26, 28-29, 155, 217; Truett and Lay 1984:89; Weniger 1984:176). Evidence of the widespread use of wildlife as a food source was especially apparent in areas where human populations increased dramatically; in the 1840s, Matilda C. Houstoun, remarking on the scarcity of animals near Galveston, a principal point of disembarkation for immigrants, wrote that "the daily search of the German emigrants for food, fully accounts to us for the diminution of game on the island. . . Everything has been destroyed, or scared away by the hungry Germans, and no living creature is now to be seen but a pelican or two on the shore" (Weniger 1984:177).

While settlers most often hunted and killed wildlife for food, they also carried on campaigns to eradicate species that were unfamiliar. Driven by the belief that a humanly created and organized landscape was superior to what may have appeared to be a naturally chaotic one, settlers worked to "improve" and "tame" their surroundings, usually at the expense of unfamiliar plant and animal species. Simultaneously, farmers and ranchers who had introduced non-native plants and animals waged war against any native species which competed for environmental space (Doughty 1983:22, 73, 107, 149, 155-156, 217). As a result, species such as the parakeet which were once prolific in East Texas were shot on sight by farmers because they were partial to young corn. As Truett and Lay (1984:74) wrote, quoting the Louisiana naturalist George Lowery and adding their own observations, "'the bird was a rogue. It ate farmer's corn and raided his orchards, destroying almost every kind of fruit indiscriminately.' East Texans made their choice. Winged beauty paled beside full pans of cornbread."

A third way in which early residents of Texas used natural resources was for sport or recreation. Doughty wrote eloquently of the personal pleasure which often resulted from the practice of setting out for a day's shooting with friends, engaging in a hunt which yielded game that could be eaten that evening or given away as a favor. other writers spoke of the pleasure associated with learning woodcraft sufficiently well to become successful hunters. Residents and foreign-born travelers alike enjoyed experiencing the frontier by identifying and securing game animals (Doughty 1983:24, 79-80). All of these endeavors helped to establish personal and community bonds.

Outdoorsmen spun long and "tall" yarns about their dogs and the prey that they brought to bay. They discussed the advantages of night lighting, jump shooting, and decoys and blinds. Dinner conversations analyzed the effectiveness of these and other techniques, such as the susceptibilities of certain animals to mounted hunters and the use of different firearms in certain terrain or weather conditions. As the numbers of Texans increased and as hunting lore was passed down from father to son, settlers decimated populations of preferred wild animals [Doughty 1983:219]. 
Coequal in importance to man's utilization of game for food in its effect on wildlife populations was the practice of killing for profit, an activity that was facilitated by the development of commercial markets and the invention of equipment that increased profitability. From earliest historic times, the skins of bison, deer, cougar, wolf, and other species were important trade and sale items in Texas where pelts sometimes took the place of currency. By the 1830s, the Mexican government had established centers such as that at Fort Tenoxtitlan on the Brazos River to facilitate trade in hides between Mexican and Indian populations; a decade later, the Texas Legislature encouraged the establishment of five trading posts along the Indian-White frontier. One of the best known of these, Torrey's Trading House No. 2 (see Table 2), served as the point to which Indians brought innumerable hides which were then shipped to the market in Houston (Doughty 1983:33-36).

The rise of markets such as those in Houston, Galveston, and San Antonio increased pressure on wildlife populations as fishermen and hunters worked to supply meat, fish, feathers, and skins. Transportation of these products to urban areas as far away as St. Louls and Chicago was made possible by the development of refrigeration and the construction of railroads (Doughty 1983:157). The rate at which hunters were able to supply products to markets increased in direct, proportion to the development of improved firearms. The availability of guns that were effective in killing not only large game (such as the flintlock Kentucky rifle, Hawken, Sharps .50-caliber, and Winchester Model 1873 highvelocity hunting rifle) but also fowl (such as breechloading shotguns) increased the hunter's effectiveness and increased the profitability of the wildlife product (Doughty 1983:98-99).

\section{Effects of Uncontrolled Exploitation*}

The effects of the need for food, hunting for sport, competition of man with wildlife for environmental space, and increased profitability of markets were twofold. First, as time passed and hunting continued unabated, there was a decline in the numbers of animals represented in each species. Randolph B. Marcy remarked on this phenomenon when he compared the thousands of deer he had seen in South Texas in 1846 with the infrequent herds of 10 which he saw in 1855. Frederick Law Olmstead also noted the phenomenal decline in numbers of large game in general and attributed the disappearance of deer, buffalo, and other native animals to their retreat from the line of settlement (Doughty 1983:111-112).

A second effect of unrestrained hunting was the extinction of certain species and a loss of variety and heterogeneity in the natural environment. In a scenario which repeated that played out in Europe centuries before, important game species were completely eradicated in Texas, often by hunters who understood that the combination of profitable markets and a readily accessible product would likely result in the extinction of the product.

*The discussion here pertains only to the negative effects of humanly generated pressures on wildlife. Concurrently, there was a wildlife conservation movement which began in Texas as early as the latter half of the nineteenth century in response to concerns over dwindling numbers of animals and species. In the late 1920s and early 1930s, these concerns resulted in the creation of the Game, Fish and Oyster Commission, a State agency which was instrumental in the conservation of wildlife (see Freeman 1987). 
In Texas, buffalo were sighted by Alvar Nuñez Cabeza de Vaca on the coast in 1528 (Haines 1975:28, 32; Truett and Lay 1984:29) and by Francisco Vásquez de Coronado in 1541 when he marched from east of the Pecos River into the Texas Panhandle and on to the Great Bend of the Arkansas (Haines 1975:34). According to Coronado, the animals ranged as far east as the coast and thence northwardly covering a district of more than 400 leagues (approximately 1,200 miles) (Haines 1975:28).

In 1685, Henri Joutel, chronicler for Rène Robert Cavelier, Sieur de la Salle, confirmed the presence of buffalo in East Texas and on the Coastal Plain as did Fray Isidro Felix de Espinosa near Nacogdoches in the early 1700s, Stephen F. Austin on his trip near the Navasota and Brazos rivers in 1821, and William B. DeWees a year later near the area where Little River joined the Brazos (Truett and Lay 1984:29).

In the early 1840s, members of the Texan Santa Fe Expedition who traveled from between present-day Williamson County, Texas, to Santa Fe, New Mexico, reported buffalo to be numerous and widely distributed. Expedition member Thomas Falconer described the vast herds as being "like a black cloud" on the prairie. Indeed, as late as 1852, resident J. T. Hazelwood found northeast Texas, to be full of vast herds of buffalo (Doughty 1983: $39-40$, 46), an observation that was reiterated by travelers in northwest Texas who described herds holding between two and four million head of buffalo. As Wayne Gard (1959a:5) commented, "many frontiersmen, like the Indians, thought there were enough buffaloes to last forever."

Impacts on the Original Range

Despite their enormous numbers, it was apparent to some observers as early as the 1840 s that pressure was being exerted on the buffalo population. As George Wilkins Kendall remarked:

It would seem almost impossible, especially to one who has seen them, numerous as the sand of the seashore, on their immense natural pastures, that the race can ever become extinct; but when he reflects upon the rapid strides civilization is making westward upon the domain of the buffalo, he is brought to feel that the noble race will soon be known only as a thing of the past [Doughty 1983:47].

Declines in buffalo populations prior to the 1860 s were attributable to a wide variety of activities carried on and pressures exerted by both Indian and White populations. Foremost among these activities was the hunting of buffalo for food and for the acquisition of marketable products including meat, furs, and skin. Such hunting occurred as soon as European populations came into contact with herds in the eastern United States and continued unabated until the South Carolina Piedmont buffalo population had been killed off by 1775 (Haines 1975:75). By 1800, all the land east of the Mississippi and in the Ohio Valley had been cleared of buffalo due to pressures by White agriculturalists and Indian hunters while the herds in the west shrank as well, retreating to the center of the Great Plains (Haines 1975:79, 156) (Fig. 1).

While herds east of the Mississippi and north of the Ohio were exterminated because they competed with agricultural activities and because they represented a readily 
Truett and Lay (1984:125) have suggested that the exploitation of specific natural resources frequently had an almost coincidental quality to it:

In his zeal to hack a living from the wilderness, Grandfather used up a lot of things. He knowingly exterminated some, perhaps because he thought they weren't worth saving. He took other things that he knew were useful; maybe he thought they would renew themselves. But mostly he probably never thought at all; he just did whatever made living better at the time.

Such a "thoughtless" response may have been responsible for the disappearance of numerous types of natural resources in Texas. But the nineteenth-century eradication of certain highly visible game species more frequently occurred during the organized pursuit of economic profits which resulted from the transformation of animals into sources of monetary gain.

\section{Buffalo as a Superabundant Natural Resource}

Original Range

More than any other large game animal, the bison of North America came to represent "the biological wealth of the frontier" (Doughty 1983:44): Its size, numbers, and multiple uses made it the ideal animal for monetary exploitation. Simultaneously, its inseparable relationship and identity with the Plains Indians and the extent to which it competed with livestock and farmers for grass and space made its eradication a positive goal.

Identification of buffalo as an apparently inexhaustible resource was logical. At the height of its numbers and range, the animal covered approximately one-third of continental North America. From the Great Plains, which remained its favorite habitat, buffalo moved north to the Canadian forests and northwest into Montana and Wyoming. Migration east eventually led the animals to cross the Mississippi and Ohio rivers and enter the lowlands of Kentucky and valleys of West Virginia (Hornaday 1971:376-377; Haines 1975:73-74). At its greatest extent, the buffaloes' habitat reached

from the Great Slave Lake on the north, in latitude about 62 degrees, to the northeastern provinces of Mexico, as far south as latitude 25 degrees. Its range in British North America extended from the Rocky Mountains on the west to the wooded highlands about six hundred miles west of the Hudson Bay, or about to a line running southeastward from the Great Slave Lake to the Lake of the Woods [Rister 1929:34].

Impediments to the animals' spread included the Canadian coniferous forests on the north, the chaparral thickets of south and southwest Texas on the south, and the Atlantic tidewater on the east. The Rocky Mountains on the west could be crossed at South Pass in Wyoming and the upper Yellowstone and Missouri rivers in southwestern Montana with the result that limited numbers of buffalo were found near the Columbia River and Great Salt Lake and in southwestern Colorado (Haines 1975:31-32). 

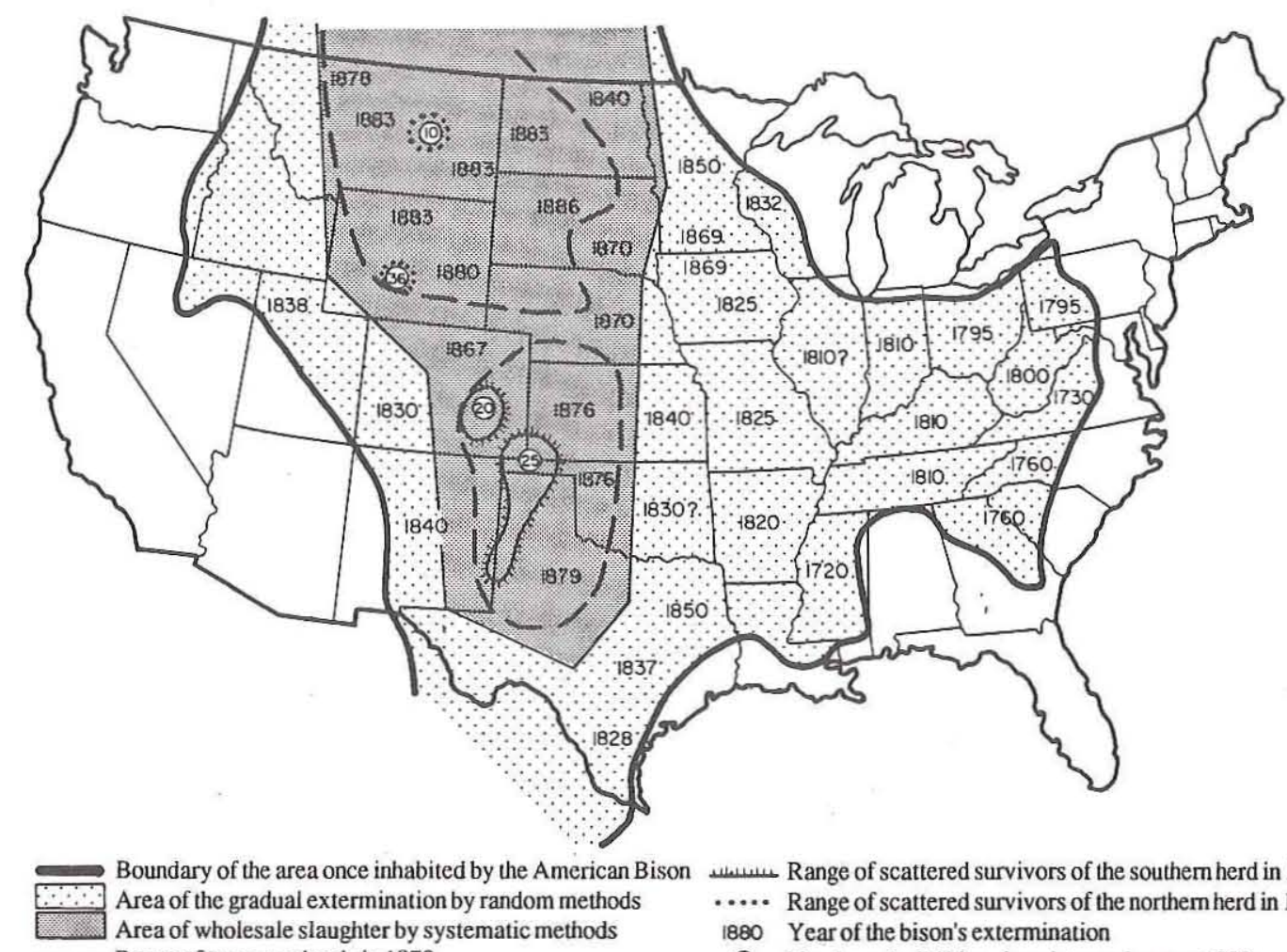

Boundary of the area once inhabited by the American Bison Area of the gradual extermination by random methods Area of wholesale slaughter by systematic methods طس山سل Range of scattered survivors of the southern herd in 1875 - - Range of two great herds in 1870 .... Range of scattered survivors of the northem herd in 1884 1880 Year of the bison's extermination

(22) Number of wild bison in existence January 1889

Figure 1. Historic range of the American bison; adapted from Hornaday (1971).

accessible food source, the Canadian herds were exploited for furs and meat alone. Construction of Fort Gary at the mouth of the Assiniboin River by the Hudson's Bay Company and organization of the annual Red River hunt by White-Indian métis resulted in major impacts on the Canadian herds by 1840 when the hunt yielded ca. 1,008,000 pounds of dried meat, grease, pemmican, and tallow, the equivalent of approximately 7,000 buffalo (Haines 1975: 130-133).

In the upper Missouri River region, vast numbers of hides were being sold or exchanged by the Indians, and in 1845 General John C. Fremont reported that sales of hides to the American Fur Company had totaled approximately 900,000 during the previous decade. A contemporaneous report estimated the slaughter of buffalo by Indians alone throughout all areas where hunting occurred to have totaled some 5,000,000 animals in 10 years (Rister 1929:41).

Contemporaneous with the activity of hunting for food and for profit was the phenomenon of hunting for sport. While sport hunting never threatened to decimate the herds, it was an integral part of the nineteenth-century slaughter and was widespread geographically. The urge to kill more than could actually be used occurred as soon as Europeans came into contact with the abundant buffalo, and in the 1770s a traveler east of the Mississippi 
commented that "we found it very difficult at first to stop great waste in killing meat. Some would kill three, four, five, or half a dozen buffaloes, and not take half a horse load from them all" (Haines 1975:77), a practice not unknown among Native American populations. In the nineteenth century, European sportsmen eager to kill buffalo became a familiar sight on the Great Plains (Gard 1959a:74), and the railroads constructed in the 1860 s used mounted buffalo heads and live animals on tour to advertise their lines. According to one historian, excursion trains ran regularly across Kansas, and each one carried rifles and ample ammunition. "West of Ellsworth buffalo could usually be found near the tracks, often galloping alongside the cars. Passengers were encouraged to shoot at them from the moving train, which rattled along at about fifteen miles an hour, a pace the buffalo could match for some distance" (Haines 1975:175-176). As late as 1877, sportsmen still set out in search of herds. Two such hunters, Elliott and John Roosevelt (brother and cousin of Theodore), traveled west of Fort Belknap, Texas, to Blanco Canyon where they made camp, shot a few buffalo, had narrow escapes from wounded animals, and were frightened by Indians before returning to Fort Griffin (Gard 1959a:234).

Hunters exerted direct pressures on buffalo herds as did farmers who moved especially strongly against the heartland of the southern herd in Kansas. The clash of slavery and antislavery forces, each of which encouraged partisans to immigrate to the area, crowded out Indian and buffalo alike, effectively driving herds from the wide belt of grassland which had served as spring pasture (Haines 1975:159). Other activities had unexpected but equally devastating impacts on the herds, the most significant of these being the development of cattle and emigrant trails and the construction of transcontinental railroads.

The impact of emigrant trails was a subtle one initially. As early as 1849, a relatively small number of wagon trains crossed the plains on their way to Oregon and California. The trickle became a flood, however, as each year between 1848 and 1865 brought new western destination points including the gold fields of California and new boom towns in the Rocky Mountains. During that time, travelers killed off or drove out buffalo along a wide strip which ran along the Kansas and Platte rivers, and then followed the North Platte in Wyoming. Eventually, the herds became divided into a northern segment and a southern segment (Rister 1929:35; Haines 1975:5), the latter herd ranging in the region "embraced by a circle with its southern side resting in northern Texas and extending to about latitude 41 degrees on the north" (Rister 1929:35).

The division of the buffaloes' range on the Great Plains was further exacerbated by the invasion of longhorns which were driven up trails from Texas during the 1860s. By the end of the decade, cattle trails were not only fragmenting the southern buffalo herd on the Great Plains but also compacting the range on both the east and the west. Longhorn herds occupied the grassy belt from Indian Territory to the Dakotas while rapidly filling up the pastures along the foothills of the Rockies (Haines 1975:172-174).

Finally, emigrant trails and cattle trails were accompanied by construction of a transcontinental railroad system, an event which further divided the herds, brought more settlers to the buffalo range, provided a market for various buffalo products, and stimulated the development of urban markets outside of the immediate vicinity of the range (Roe 1972:427, 814). Construction of the Union Pacific Railway began at Omaha, Nebraska, in 1865; two years later the line was completed to Cheyenne, Wyoming. To the south, the Kansas Pacific and the Atchison, Topeka, and Santa Fe were constructed between 1866 and 1871 through the heart of the buffalo range in Kansas. By September 1872, the Atchison, Topeka, and Santa Fe, approximately paralleling the Santa Fe Trail, reached Fort Dodge, 
later the important trade center Dodge City (Roe 1972:428, 431) (Fig. 2). According to Roe (1972:431), "the southern herd was literally cut to pieces by railways, and every portion of its range rendered easily accessible. . . [A]s soon as the railways crossed the buffalo country the slaughter began."

Post-1860 Systematic Exploitation of the Southern Buffalo Herd

Most historians date the maximum exploitation and eventual destruction of the southern herd of buffalo to the two decades following construction of the transcontinental railroads. According to Rister (1929:43), Hathaway (1931:107), Roe (1972:416-417), and Haines (1975:6, 174), the railroads created a demand for buffalo meat to feed railroad construction crews and, later, to satisfy the country's taste for buffalo meat and tongues. The lines also furnished inexpensive transportation for western products such as buffalo hides and skins to eastern tanneries. And the railroads made possible the platting of numerous towns which provided bases for hunters operating in buffalo country. "Where formerly it was necessary for the hunters to haul their supplies hundreds of miles from the settlements into the buffalo country, now it was but a matter of a few hours' drive from the new railway shipping points to the buffalo region" (Rister 1929:43).

Not surprisingly, the focus of the earliest exploitation of the southern buffalo herd occurred in Kansas where local demand for meat was high and the means of transporting the buffalo product to markets outside the region were readily accessible. At this point, the geographical center of the herd was near the present-day site of Garden City, Kansas. Its eastern extent was near Wichita, Kansas, and its northern limit was near the Union Pacific line. On the west, some herds ranged in and near the Rockies, while their southern range extended as far as the Pecos River and Llano Estacado in Texas and New Mexico (Roe 1972: 430).

The initial slaughter of the southern herd occurred in 1872-1873 after which the herds were so depleted that hunters began to look at areas to the west and south on Kiowa Creek and later on the brakes of Medicine Lodge Creek, Sand and Crooked creeks, on Cimarron and Beaver creeks, and on tributaries of the Beaver coming out of the Texas Panhandle (Anonymous 1928:51; Baker and Harrison 1986:8). As early as 1872, hunter George W. Reighard accompanied by Zeke Ford, Tom Rooney, and Jim Whalen began to hunt in the Texas Panhandle along Palo Duro Creek and the Canadian River (Gard 1959a:107). Then, in the summer of 1873, hunters J. Wright Mooar and John Webb made a horseback trip south, each carrying 200 rounds of ammunition, a Big Fifty (.50-caliber) gun, and a pocket full of salt. They crossed Beaver Creek, went south across Wolf Creek, and turned west and followed the divide between the Canadian River and Palo Duro Creek until they could see the brakes of the Blue River. They then turned north across Palo Duro Creek, San Francisco Creek, Coldwater Creek, and Beaver Creek to the Cimarron River (see Fig. 2). During the trip, they encountered "buffalo, a solid herd as far as we could see[.] [A] 11 day they opened up before us and came together again behind us" (Mooar 1930:109-110).

The hunters were excited by what they had seen during their trip but concerned because they believed that the 1867 Treaties of Medicine Lodge reserved the new hunting grounds to the Comanche, Kiowa, Cheyenne, and Arapahoe Indians (Haines 1975:196; Baker and Harrison 1986:8). However, after receiving reassurances from Colonel Richard Irving Dodge, post commander at Fort Dodge, Kansas, who informed hunters Mooar and Steel Frazier that "if I 


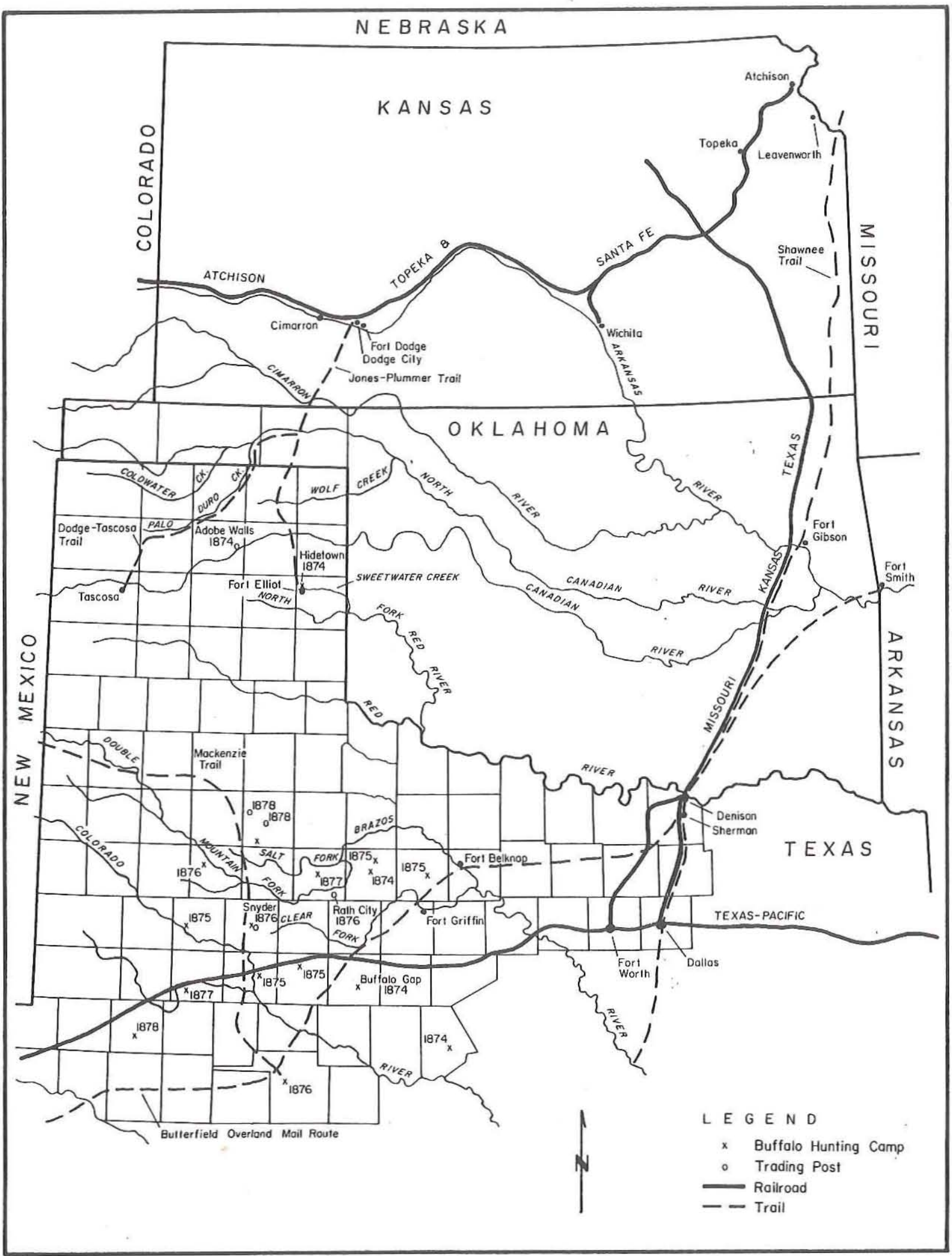

Figure 2. Historic features associated with the buffalo trade in the Southern Plains. 
were a buffalo hunter, I would hunt where the buffalo are" (Mooar 1930:110; Baker and Harrison 1986:10), outfits from Kansas reentered the Texas Panhandle and began to hunt along Palo Duro Creek and the Canadian River. Among those who spent the 1873-1874 season in Texas were Mooar, Lane and Wheeler, Jim and Bob Cator, and George Causey and Sam Carr (Mooar 1930:110; Gard 1959a:135).

Among those whom Mooar and Webb had told about the Panhandle herds were Dodge City merchants A. C. Myers and Charles Rath (Mooar 1930:110), who provided supplies to buffalo hunters and marketed the buffalo product. Deciding that substantial profits were to be made off the Panhandle herds, A. C. Myers moved a branch store from Dodge City to the Canadian River where he built a large stockade, corral, and store house. Competitor Charles Rath soon followed with a stock of supplies and built a sod structure. Other businessmen who came to the new trading post called Adobe Walls (see Fig. 2) included saloonkeeper James Hanrahan and blacksmith Tom O'Keefe (Anonymous 1928:451; Mooar 1930: 111). According to Rathjen (1973:157), the Panhandle subsequently became a commercial satellite of Dodge City, Kansas, which had the Santa Fe Railroad and served as a gateway to the Panhandle by virtue of its providing the area with its only access to the outside world.

With supplies and markets available in the middle of the buffalo country and with the tacit approval of the military, hunters rapidly moved into the Texas Panhandle. Among those who set up camps in the area in the spring of 1874 were Billy Dixon on Dixon Creek (probably in present-day Carson County) and J. Wright Mooar south of the Canadian. Mooar later estimated that there were as many as 50 outfits operating in the Panhandle. These probably were situated along the breaks of Wolf and Palo Duro creeks, the Canadian River and its tributaries, and the North and Salt forks of the Red River (Rathjen 1973:158-159) (see Fig. 2).

On the morning of June 27, 1874, a large group of Comanche and Cheyenne Indians attacked Adobe Walls. While the attack ultimately was unsuccessful, the event, coupled with a series of isolated attacks on individual camps, frightened the buffalo hunters and trading post merchants sufficiently so that they temporarily abandoned the post and the Panhandle buffalo range soon after and returned to Dodge City (Gard 1959a:166; Rathjen 1973:166).

The Panhandle remained attractive to buffalo hunters even after the attack on Adobe Walls: the Cator brothers returned by the fall of 1874, and in 1875 John Woods and George Simpson hunted on Gageby Creek, Richard Bussell hunted near the present-day sites of Canadian and Clarendon and on the Quitaque, and approximately two dozen other outfits of six men each operated in the eastern Panhandle. Indeed, the concentration of hunters in the eastern Panhandle after the Battle of Adobe Walls was sufficiently great to generate the development of a new trade center named Hidetown which was located approximately $1 \mathrm{mile}$ east of present-day Mobeetie (see Fig. 2). Hidetown became the reception center for buffalo hides which were then freighted to the railroad at Dodge City by way of the JonesPlummer Trail (see Fig. 2) named for two Hidetown merchants. At Fort Elliott (see Fig. 2), established nearby in 1875, post traders Lee and Reynolds also supplied the buffalo hunters who operated along the Canadian and upper reaches of the Red River (Rathjen 1973: 166-167). But many other hunters decided that the profits to be made were not equal to the risks involved, and so they began to search for another, safer route to the buffalo country in west-central and northwest Texas. 
Among the first to establish a new route were the Bussell brothers who traveled east to the Arkansas River which they followed downstream to the eastern part of Indian Territory. Near Fort Gibson they met the Texas Road which was paralleled by the Missouri, Kansas, and Texas Railroad and traveled south on it to the Red River. They entered Texas just above the new railroad town of Denison where they turned southwest and went to Sherman. At this point, the Bussells turned west and followed the Butterfield Trail past Fort Belknap to Fort Griffin on the Clear Fork of the Brazos where they arrived on August 1, 1875 (Gard 1959a:183-184) (see Fig.2).

In the fall, the Bussells left Fort Griffin and rode approximately 20 miles north to Elm Creek where they camped, killed, and skinned throughout the fall and winter. At Caddo Peaks, ca. 65 miles from the town of Comanche and in the vicinity of Buffalo Gap in present-day Taylor County, a group of six hunters killed buffalo for meat, an objective shared by a group of hunters who left Brownwood in October 1874 and killed enough animals to "furnish Brown County with meat all the next year" (Gard 1959a:189-190). Other hunters west of Fort Griffin during the winter of 1874-1875 included the Bussells, who followed the Pease River and Prairie Dog Fork of the Red before camping on Mulberry and Sweetwater creeks (Gard 1959a:195), and Joe S. McCombs who, with skinners John Jacobs and Joe Poe, followed the Mackenzie Trail and camped ca. 6 miles northeast of present-day Haskell before moving to the Clear Fork of the Brazos where they took 1,300 more hides (Rathjen 1973:168169) (see Fig. 2).

The spring of 1875 found J. Wright and John W. Mooar reentering Texas from Kansas by way of the Shawnee Trail, Fort Gibson, Denison, and Fort Griffin (Gard 1959b:38). According to Mooar, their objective was to get on the south side of the buffalo herd. At Fort Griffin they were ordered by General Buell not to venture more than 20 miles from the Fort. However, they ignored the order and traveled 100 miles beyond (Mooar 1928:90), following the Brazos and making winter camp on Mule Creek at the future site of Weinert where they gathered 4,000 hides (Gard 1959b:39). In the same year, Frank Sherrod's outfit made camp at the head of the Colorado River and then hunted in the Colorado River valley, Joe McCombs made camp near present-day Colorado City on Champion Creek (Gard 1959a:203), and Charles Hart made a foray into the Brazos and Pease river regions and camped near the Salt Fork of the Brazos (see Fig. 2). According to one of Hart's skinners, the party camped "in the midst of a vast sea of animals" (Branch 1929:201).

The routing of the Comanches from Palo Duro Canyon by Ranald Mackenzie in the fall of 1874 had made the buffalo country significantly safer for hunters by late 1875 . In response to this factor, and to the reports of abundant herds in west and northwest Texas, the slaughter of the southern herd in Texas reached its peak in the winter of 1876-1877 when Gard (1959a:218) estimated that there were 1,500 hunters and skinners on the range. Fort Griffin prospered as headquarters for the trade, which spread out over the Rolling Plains and along the Colorado, Brazos, and Pease rivers. In 1876, Charles Hart led a party from the Pease to the Salt Fork of the Brazos where they gathered 3,361 hides which were then hauled to Fort Griffin. The Woodys and Rumphs hunted in present-day Garza and Borden counties, while an outfit for which S. P. Merry of Arkansas was cook and hide pegger hunted near the present-day site of Snyder. John C. Jacobs and John W. Poe hunted on the western ranges in the winter of 1876-1877, while Joe S. McCombs made winter camp west of Colorado City on Morgan Creek where he collected 2,300 hides. To the south, hunter Windy Bill Russell made camp in a dugout on the Middle Concho near present-day Ben Ficklin where he made a big haul of hides (Woody 1926, 1928; Gard 1959a:223, 229, 230, 251). The fall and winter of 1877 found Joe McCombs hunting in the vicinity of present-day Big Spring, Jacobs 
and Poe piling up 6,300 hides not far to the north, the Mooars hunting along Deep Creek, and Tom Bird hunting in the vicinity of Croton Creek and the Double Mountains (Gard 1959a: 251; Dumont 1988:35-37) (see Fig. 2).

By the winter of 1878-1879, it was clear to J. Wright Mooar and other hunters that the abundant buffalo herds had all but disappeared in Texas. Some desultory hunts were made on the Llano Estacado and as far south as the vicinity of Mustang Pond near present-day Midland (Gard 1959a:253) (see Fig. 2), but hunters at Fort Griffin agreed that the herds seemed to have moved north. By the spring of 1879, the buffalo had been all but exterminated on the Rolling Plains and in the Panhandle, and entrepreneurs still interested in the hunt were forced to move north to the Northern Plains and the upper valley of the Missouri River (Gard 1959a:256).

Development of Markets for the Buffalo Product

Between 1865 and 1879, the, southern herd of buffalo was systematically destroyed by outfits of hunters and skinners who operated in Kansas, Oklahoma, and Texas. The rapidity with which the destruction occurred testified to the strength of the markets that existed for the buffalo product. This strength, in turn, was predicated on transportation routes, technological developments and inventions, and markets which expanded throughout the United States shortly after the Civil War.

\section{Construction of Railroads}

The development that was the sine qua non for the buffalo products market was the railroad. Indeed, Roe (1972:814) stated that the hide hunter "of the final era, did not make his appearance in the Southern buffalo territory until the advent of the railway made marketing possible, about 1867." The Atchison, Topeka, and Santa Fe, completed to Dodge City, Kansas, in September 1872 (Roe 1972:428), effectively opened the area occupied by the southern herd to exploitation by providing transportation to White hunters and the supplies necessary for their trips into the plains hunting grounds which were distant from rail lines. The railroads provided markets for meat as contractors employed hunters to kill buffalo with which to feed railroad construction crews (Hathaway 1931:107; Haines 1975: 174); they also provided transportation for the buffalo product to markets in the Midwest and East. Finally, railroad crews who found themselves out of work following completion of various rail lines turned readily to buffalo hunting, the occupation that seemed to hold the greatest promise for easy money. According to Haines (1975:191), the winter of 1872 marked the all-time high for numbers of hunters, skinners, drivers, cooks, and helpers in the field at one time (some 10,000-20,000 men). Not surprisingly, that winter also marked the largest number of hides brought in to market.

Technological Developments and Inventions

While railroads were essential to the system, certain technological developments were also important to its success and to the marketability of the product. Until the 1870s, 
buffalo were hunted for their robes or for their meat because the hide when tanned by conventional methods was considered to be too soft and spongy for general commercial use. In 1870, Kansas City hide, fur, and wool dealer J. N. DuBois shipped some bales of buffalo hides to Germany where tanners had invented a process for making the hides into good leather (Gard 1959a:91). The following year, John W. Mooar sold a consignment of flint hides to a group of Pennsylvania tanners who experimented with the hides until they perfected their own methods of tanning them (Rister 1929:43). Simultaneously, the English had succeeded in their tanning experiments, using hides supplied by Leavenworth, Kansas, dealer W. C. Lobenstein (Lobenstine) (Gard 1959a:95). As a result of these changes in tanning methods, an entirely new market for the buffalo product was created and demand skyrocketed. As Price and Rathjen (1986:45-46) assessed the situation, "By 1872 European and American tanneries had learned techniques of tanning buffalo hides that produced leather of unique traits, making it highly desirable for certain uses, such as the belting which manufacturing plants of the time used for conveying energy from power source to machine."

J. N. DuBois, who had initiated the process that opened new markets for buffalo hides, introduced several other new developments that increased profitability. ;According to Gard (1959a:91), the Kansas City dealer distributed hundreds of circulars on the buffalo range, advertising his willingness to purchase hides no matter what time of the year they were harvested. He provided information to hunters about methods of pegging and drying hides and sold them a South American poison (arsenic) which was effective in killing bugs that often infested and damaged the hides before they were delivered to market.

Tanning, drying, pegging, and preservation inventions and developments were all important aspects of the buffalo market. Of equal importance was the development of new guns manufactured specifically for the buffalo-hunting trade. The most desirable of the guns was the Sharps Big Fifty, which supposedly was designed by the Sharps Rifle Manufacturing Company of Bridgeport, Connecticut, as a result of correspondence between the Company and the Mooar brothers (Anonymous 1928:452). According to former buffalo hunter W. S. Glenn (1949:23), the gun was the result of considerable experimentation by the Company which first manufactured an octagonal-shaped barrel ranging in length from 26 to 30 inches. The .50 -caliber gun used 380 grains of lead and burned 120 grains of powder, and included a reloading outfit with a bullet mold to make bullets in the field.

In response to a complaint that the bullet drifted too much, the Company made a .44caliber shell that was bottle-neck shaped but burned the same amount of powder and lead. When this gun leaded too badly, Sharp made a .40-caliber gun with less powder and lead, but this proved not to be sufficiently powerful. The most successful results, according to Glenn (1949:23), were obtained from the .45-caliber weapon which used 380 grains of lead and 120 grains of powder, but the literature is full of references to the success which hunters achieved with their "Big Fifties." Indeed, Haines estimated that at least threefourths of all commercial hides taken were harvested by hunters using either the large Sharps single-shot breechloader or the large single-shot Remington. Most of these guns "were about [.]50-caliber and shot a ball weighing about an ounce (437.5 grains), with some hunters using all the way from 320 grains to 550 grains. Such a gun was accurate to 800 yards, and with a good telescopic sight was deadly against even the toughest bull at 300 yards" (Haines 1975:195). 
Demand for the Buffalo Product: Furs, Hides, and Meat

The third factor that had a significant impact on the development of markets for the buffalo product was the demand that arose for all parts of the animal. Indeed, it was this demand that resulted in the expansion of the hunting season from a seasonal to a year-round occupation. Initially, the greatest demand was for buffalo robes taken in the winter when the hair was thick and long. In 1870, New York dealers paid approximately $\$ 16.50$ per robe in lots of 100 while exhorting their clientele to purchase what were "once the very best clothes of a roamer over the Buffalo Range" (Branch 1929:153). Hunter Glenn (1949:22) remarked that, even during the 1870s, he "killed expressly for the robes" between November 1 and February 15. These robes were then shipped east, many of them to the two leading tanning concerns in Connecticut and Michigan (Anonymous 1928:452).

After 1871, the demand for hides for leather outdistanced that for robes. The nearly bare summer skins became desirable for their potential use in leather products with the result that hide hunters were able to work year round. Tanners who had found that they could make a profit off the summer as well as the winter hides sent orders to Kansas from the East Coast and Europe. "Competing buyers showed up at every railroad shipping point near the buffalo country, most of them ready to pay cash on the spot for hides as they were hauled into town, and piling their purchases along the railroad sidings until they could be shipped" (Haines 1975:190).

The demand for furs and leather was matched by a demand for buffalo meat. The railroads used buffalo meat to feed construction crews while butcher shops and restaurants in the buffalo region and far removed from it provided another market (Baker and Harrison 1986:4). Increasingly, Europeans acquired a preference for buffalo tongues and hams which hunters could supply fresh during the winter months or salt-cured and smoked year round. By 1871, hunters were marketing meat at towns along the length of the railroads which bisected the buffalo country, while other entrepreneurs shipped the meat to Kansas City, St. Louis, and points east where it was distributed to butcher shops and restaurants (Gard 1959a:86-87; Haines 1975:189). According to Douglas Branch, buffalo steaks were sold at all western railroad eating houses and hotels. Indeed, demand for the product was sufficiently intense to result in the creation of specialized hunters and merchants such as A. C. Myers who built a smokehouse on Pawnee Fork. Here Myers divided each hindquarter into three pieces, sugar-cured, smoked, and sewed each piece into canvas, and sold the product to eastern markets (Branch 1929:153-154).

Buffalo Hunting as a Business: Structure of the Trade

The efficiency with which hunters exploited and exterminated the buffalo herds of the Southern Plains and the rapidity with which the buffalo products were delivered to appropriate clients throughout the United States and in Europe were directly attributable to the fact that the buffalo trade was an organized system. The system consisted of several key components which were dependent upon one another, were well integrated, and resulted in the creation of specific archeological and architectural property types (Table 3). Elements of this system had been in place prior to the construction of the transcontinental railroad system when central markets for furs and meat were developed in St. Louis, Missouri, trading posts were established, and Indian and White hunters began to provide the products of 
TABLE 3

BUFFALO HUNTING ON THE ROLLING PLAINS, 1874-1879: EXPECTED PROPERTY TYPES

Property Type Description Examples

Railroads

Rail lines and railheads located in North-Central Texas in major trade centers; used to transport buffalo products to eastern and midwestern markets.

Central Markets Towns

Mercantile

Houses

Trading Posts and Stores
Towns and cities located in North-Central Texas with direct access to major railroads; locations of commercial businesses engaged in the buffalo trade between the fall of 1874 and 1879 .

Towns located in West Texas with direct access to major railroads; locations of commercial businesses engaged in the buffalo and bone trade after 1877 .

Commercial establishments located in North-Central Texas whose 1874-1879 income derived principally from marketing of buffalo products and supplies sold to hunting outfits. In most cases, owned by merchants with business ties to other merchants in Kansas. May have been located in forts at some distance from the buffalo hunting range.

Commercial establishments distant from towns which provided supplies to hunters and purchased hides and meat. Such posts often were operated in conjunction with saloons; typical architectural forms were dugouts made with poles and buffalo hides, and sod and picketed structures.
Texas and Pacific

Denison

Fort Worth

Colorado City

A. S. Holland, Denison Joseph H. Brown, Fort Worth J. L. Hickey, Fort Worth Frank E. Conrad, Fort Griffin

Rath City (Stonewall County) Cornelius' Store (Scurry County) Snyder's Store (Scurry County) Dockum's Store (Dickens County) Store and dance hall on Red Mud Creek (Dickens County)

Parrish Store, Dickens County Davis Store, Dickens County 
Table 3, continued

Property Type Description Examples

Hunting Outfits Often ephemeral sites with or without architectural features located at and Camps some as-yet-undetermined distance from trading posts. Architectural

features included dugouts and smokehouses. Sites without architectural

41 GR528

components might include features associated with tepeelike shelters.

Stands

Ephemeral sites up to several miles distant from a hunting camp.

Artifacts associated with shooting and butchering activities might be

present; these would include ammunition, knife parts, and evidence

of butchered bones. 
PHASE II HISTORICAL INVESTIGATIONS, JUSTICEBURG RESERVOIR

the hunt (Haines 1975:188-189; Baker and Harrison 1986:3). But the florescence of the market system occurred only after the construction of the railroads when the sheer volume of the buffalo product necessitated the development of a highly structured organization.

\section{Central Markets}

J. W. Mooar (1928:91) wrote that "buffalo hunting was a business and not a sport; it required capital, management and work, lots of hard work, more work than anything else." A key element in this business was William Christian Lobenstein of Leavenworth, Kansas, who was described as the "ram rodder of the buffalo hunt" (Glenn 1949:20). Lobenstein, a native of Germany and veteran of the California Gold Rush, had stimulated the first largescale hunting of buffalo for their hides in the early 1870s when he passed an English order for 500 hides to Charles Rath, a Kansas merchant and trader who sometimes worked as a hunter himself (Baker and Harrison 1986:4). According to former buffalo hunter W. S. Glenn (1949:20), Lobenstein furnished the capital necessary to underwrite merchants and hunting parties and sublet contracts for robe hides, dry hides, bull hides, and other buffalo products. In some cases, the merchants who furnished hunting parties with supplies and equipment and then received the buffalo products were agents for and worked with Lobenstein. Among these were Rath in Dodge City, A. S. Holland in Denison, Texas, J. L. Hickey in Fort Worth, and other individuals in Dallas and at Fort Griffin (Gard 1959a:39, 198, 200, 204, 253). In other cases, merchants independently used a credit system, underwrote many of the large, well-organized hunting parties, established trading posts in the range itself, and purchased the hides and meat which were products of the hunt (Branch 1929:158). Among these individuals were Rath and A. C. Myers of Fort Hayes, Kansas, who hunted buffalo and then shipped the meat with the hides still attached to Kansas City and St. Louis in 1870 (Mooar 1930:109); and Wright, Beverly and Company, and Alexander Charles Myers and Frederick J. Leonard, all of Dodge City (Branch 1929:154; Baker and Harrison 1986:10).

By 1872-1874, prosperous merchants in major Kansas rail towns in the midst of the buffalo country, such as Dodge City, Wichita, and Leavenworth, were sending out wellorganized parties of hunters (Rister 1929:46; Roe 1972:432). Typically, they advanced guns, ammunition, and supplies to buffalo hunters on a credit arrangement or a stated percentage of hides taken. They then collected the hides and meat, forwarding them to markets farther east (Branch 1929:154; Gard 1959a:115). However, as the buffalo range shrank and towns like Dodge City became more distant from the resource, merchants were forced to formulate solutions to the problem of ever-more-distant herds. Typically, they responded in two ways. In some instances, they underwrote the cost of establishing trading posts in the midst of the herds; in other cases, they established stores in existing communities closer to the herds than Dodge City. Both actions were aimed at provisioning the hunting outfits and being in a position to receive the buffalo product.

\section{Trading Posts and Stores}

Establishing and provisioning trading posts distant from the railroads and major population centers could be a perilous enterprise, but the profits to be derived from the hide and meat business apparently offset the dangers. One of the first such posts to be built in Texas was Adobe Walls which was located near the older abandoned Bent's Fort near 
the Canadian River (see Fig. 2). The post was established in the spring of 1874 in response to reports of the great buffalo herds still remaining in the area; it was designed to overcome the obstacles posed by the distance of the range from railroads and markets. Alexander Charles Myers and his partner, Frederick J. Leonard, among the most prosperous merchants in Dodge City, offered to construct and supply a trading post in the midst of the new buffalo range if the hunters would work full time in the Panhandle (Baker and Harrison 1986:10). The hunters responded enthusiastically, and in March 1874 a train of approximately 100 wagons of hunters and merchants left Dodge City for Texas laden with supplies that the hunters had purchased and with goods for the store that Myers and Leonard intended to build. The construction of their store and of a competing store shortly thereafter by Charles Rath and Company, also of Dodge City, effectively extended a portion of the merchants' operations to the Texas Panhandle (Baker and Harrison 1986:11, 18), putting them in a superior position to capitalize on the buffalo trade.

A second trading post that became a focal point for buffalo-related businesses after Adobe Walls was attacked by Indians and abandoned in the summer of 1874 was Hidetown, a gathering place for buffalo hunters located in present-day northwest Wheeler County (see Pig. 2). By June 1875, businesșmen Lee and Reynolds had established a tent store, and with the establishment of Fort Elliott nearby, the store was joined by a large dance hall, two restaurants, and three saloons (Gard 1959a:205).

Just as Adobe Walls and Hidetown serviced the buffalo trade in the Texas Panhandle, so several other trading posts provisioned buffalo hunters of the Rolling Plains and served as gathering depots for the products of the trade. The first of these posts was H. T. Cornelius' store on Deep Creek near present-day Snyder (later owned by Pete Snyder) (Garnsey [1952]:1-2; Knupp 1980:1). Set up in 1876 to accommodate the numerous buffalo hunters who found hunting good in present-day Garza, Borden, and Scurry counties, the store was built of chinaberry poles and buffalo hides and stocked with provisions acquired from Joseph H. Brown in Fort Worth (Gard 1959a:228). To the north in Dickens County were stores owned and run by W. C. Dockum (ca. 1877), J. C. Davis, and J. H. Parrish; as well as a store and dance hall whose owner is unknown (Holden 1932:76, 1970:33-34; Elliot 1939:9-11). To the east in present-day Stonewall County, merchant Charles Rath left Dodge City in the fall of 1876 and, after stopping by Hidetown (Mobeetie) where some merchandise was unloaded, traveled on to the vicinity of the Double Mountains. There, Rath built a store and a number of sod-and-picket buildings for the multitudes of hunters who were exploiting the large buffalo herds on the upper Brazos. Rath City (also called Camp Reynolds and Reynolds City) was a great success, and Charles Rath handled $\$ 100,000$ worth of hides in 1877 alone (Gard 1959a:231-232).

Trading posts such as Adobe Walls, Hidetown, Snyder's Store, Dockum's Store, and Rath City were established in the buffalo country far distant from towns and railroads by merchants who were willing to assume considerable risk for the opportunity to profit from the buffalo hunting business. Less risk was involved when the merchants were able to establish stores in existing communities such as Fort Worth and Denison located on major rail lines such as the Texas and Pacific or at frontier forts. Of all the communities that prospered from the exploitation of the buffalo, Fort Griffin was the one most intimately associated with the trade. Established in 1867 on the Clear Fork of the Brazos north of present-day Albany, the Fort was on the verge of becoming the most popular outpost on the Texas frontier by 1874. It became the center for the buffalo trade after the abandonment of the Adobe Walls trading post and continued to be the most convenient point of departure for buffalo hunters who wished to exploit the herds on the Rolling Plains. Until 1879, 
Fort Griffin merchants such as Frank E. Conrad sold guns, ammunition, and camp provisions, provided early banking services, and bought flint hides and meat which they forwarded to the railroad (Gard 1959a:192, 218). With the trading posts located in the buffalo range itself, Fort Griffin and its merchants provided essential goods and services to buffalo hunters.

\author{
Hunting Outfits and Camps
}

MEMBERS

The third essential component of the economic system of buffalo hunting was comprised of the buffalo hunters themselves. Frequently depicted as boorish, violent, and generally undesirable individuals, the most successful of these men were, more often than not, wellorganized entrepreneurs, many of whom went on to prosper at other economic pursuits after the buffalo herds disappeared.

While lone hunters had been typical during the prerailroad days, outfits of men were the more common pattern during the 1870s. These outfits usually were comprised of four to six individuals, each with a specific job to perform so that the largest number of hides and greatest volume of meat could be harvested with the least expense and effort and in the shortest amount of time.

Gard (1959a:116) described a large outfit comprised of 16 men which included 2 hunters, a cook, 1 gun reloader, 1 hide pegger, 2 hide haulers, and 9 skinners. More typically, outfits consisted of four to six men, each of whom had very specific tasks to perform. Head man or boss of the outfit usually was the hunter, the individual who actually located and shot the animals. Sometimes he removed the tongues or tallow (Glenn 1949: 25), but more often he was not responsible for those tasks. He was generally responsible for the profitability of the endeavor and usually kept any records associated with the hunt. John R. Cook (1907:117) recalled about boss Charley Dockum that "each night Charley got out his memorandum book and I got mine, and we put down the number of hides I had skinned that day. Isolated as we were, we kept track of the days of the week and the month of the year. This was Dockum's work. He was very methodical in everything he did."

Some of the most important members of an outfit were the skinners or strippers. These men, ranging anywhere in number from two to six on a typical hunt, drove the wagons to the location where the hunter had made a stand and shot a herd. When enough animals had been shot to keep the skinners occupied for the day, they would go to work, skinning the carcasses and removing the humps, tongues, and tallow from the bodies that were still fresh (Rister 1929:44; Glenn 1949:25). Good skinners could remove the hides from 60 to 75 carcasses a day, an average skinner from 30 to 40 , and a common one from 15 to 25 (Glenn 1949:26).

Another member of the outfit was the camp rustler who kept tally of the hides killed each day, provided the camp boss did not do the task. Tallying was necessary so that accurate payment could be made to the hunter and skinners. The rustler also was responsible for hide drying (if no one else was available to perform this task), for reloading casings, and for looking after the camp's meat and tallow (Glenn 1949:22, 28). He cooked all the meals and generally slept with the boss so that he would be sure to rise early enough to 
prepare breakfast (Glenn 1949:27). If no one else was available to do the work, the camp rustler or cook also stretched and pegged the hides and removed any excess fat or flesh from them (Branch 1929:158-159; Glenn 1949:28).

Outfits that butchered a large amount of meat sometimes included butchers or meat men who were responsible for preparing the meat after it had been brought to camp on the meat wagon (Glenn 1949:38). Preparation of various cuts usually entailed the digging of a brine pit or vat where the meat soaked for 9 to 10 days, the smoking of the meat in a trench, and the packing of the pieces in canvas wrappers so that they could be shipped readily (Glenn 1949:38-39; Haines 1975:194-195).

\section{EQUIPMENT}

Just as hunting outfits had similar component members, so also each outfit was equipped in a similar fashion. Equipment generally consisted of wagons to carry food and camp supplies, hides, and meat; weaponry such as guns and knives; and the various items necessary to load and reload cartridges.

According to Rister (1929:44-45), Hathaway (1931:108), Gard (1959a:116, 224), and Baker and Harrison (1986:26-28), provisions taken on the hunt consisted of flour, meal, bacon, canned foods, vegetables, potatoes, coffee and tea, yeast and baking powder, molasses and sugar, crackers, beans, corn, lard, soup, pickles, liquor, tobacco, various medicines and bitters, and poison used to kill bugs which frequently infested the hides. Camp equipment described by Cook (1907:111), Rister (1929:45), Hathaway (1931:108), and Gard (1959a:116) included water kegs, medium- and large-sized Dutch ovens, large frying pans, coffee pots, camp kettles, bread pans, coffee mills, tin cups loften consisting of fruit cans), plates, knives, forks, spoons, pot hooks, meat broilers, shovels, spades, axes, mess boxes, and bedding. All of these supplies and provisions were carried in wagons which Haines (1975:195) described as having steel wheels with 9-inch-wide steel rims and a steel box for hauling camp gear and supplies. The larger wagons, some of which were capable of carrying 4 tons of hides, had steel wheels and a flatbed of steel plate. While some outfits may have used wooden wagons, they tended to wear out rapidly given the rough treatment to which they were subjected and the dry air.

Perhaps the most important equipment taken by outfits on the range was that associated with the killing and processing of the buffalo. Guns came in a great variety of types and calibers, including old Kentucky muzzle loaders; condemned Spencer army rifles; .50caliber, single-shot, breechloading Springfields; Henry and Winchester rifles; Sharps buffalo guns; Enfields; single-shot Remingtons; and what were referred to as needle guns, generally thought to have been any trap-door, breechblock gun. of all of these, however, the .45- and .50-caliber Sharps, weighing ca. 14 to 18 pounds, was the gun of preference for many hunters (Anonymous 1928:452; Branch 1929:160; Hathaway 1931:108; Glenn 1949:23, 24; Gard 1959a:123-124; Rathjen 1973:170; Haines 1975:195).

Because of their distance from trading posts and stores and because of the large amount of ammunition they consumed during a hunt, buffalo hunters were forced to take along all the paraphernalia necessary to hunt successfully. Cook (1907:112) described his outfit's provisions as including " 250 pounds of St. Louis shot-tower lead in bars done up in 25-pound sacks; 4000 primers, three 25-pound cans of Dupont powder, and one 6-pound can." According to Haines (1975:195), one outfit with two hunters took along 1,600 pounds of lead 
and 400 pounds of powder, about enough for 25,000 rounds. Another hunter specified that his outfit carried 600-700 pounds of lead and 2,000-3,000 shells with primers (Hathaway 1931:108). Numerous brass cartridge cases were taken and were used repeatedly, refilled each night in camp when the men sat around a large skillet in which lead had been melted. They then dipped out the lead with a spoon and molded their bullets (Branch 1929:160).

The ammunition carried by each hunter typically consisted of an ammunition box and as many as 100 rounds of ammunition carried in a belt. Equipment carried in the box included a reloading outfit comprised of bullet molds, a primer extractor, swedge, tamper, patch paper, and lubricator (Cook 1907:86; Branch 1929:163; Glenn 1949:29). Reloading usually occurred at the end of the day when the men collected the spent cartridges and brought them back to camp. Spent primers were picked out with an awl, a fresh primer driven in with a hammer, and the shell reloaded with as many as 100-110 grains of powder in a 90-grain cartridge. The rimmer was put in and hit with a hammer, after which a wad was put on top of the rimmer, some powder added to the top of the wad, and the bullet placed on the powder (Hathaway 1931:111; Gard 1959a:125).

Skinners, like hunters, had their own particular equipment which included saws to cut pieces of meat, a good supply of skinning knives, a 16- to 18-inch butcher's steel, and a grindstone (Hathaway 1931:108; Glenn 1949:29; Gard 1959a:126). One of the preferred brands of knives was the I. Wilson, a skinning knife that was the product of John Wilson's English cutlery shop. According to Boley (Dumont 1988:163), the Wilson knife was "humble in appearance and the essence of simplicity in design. . [ [Nevertheless, the Wilson] was called by name, a distinction rarely extended to tools on the frontier." The Birds, who hunted on the upper Brazos, took two I. Wilson skinning knives and one Bowie ripping knife, the latter being a type used throughout the South and Southwest and considered to be economical and practical for skinning buffalo and cutting up the meat (Dumont 1988:23, 163).

Buffalo hunters shared not only similarities in the equipment they used but also in their preferences for camping locations. An analysis of references to campsites reveals that most hunters on the Rolling Plains and in the Panhandle selected locations adjacent to major water sources, often at the confluence of a creek and a river or at the spring-fed head of a creek (Table 4). Individuals who hunted on the Llano Estacado selected campsites adjacent to playa lakes. Such selections not only assured hunters of ready access to fresh water for drinking and processes involved in the treatment of butchered meat but also made it more likely that they would encounter buffalo.

Because every camp included oxen or mules to pull the camp and hide wagons, the availability of grass was an important consideration. Cook's (1907:114) description of the "ideal hunters' camp" included references to "plenty of fresh water, good grass, and wood in abundance," the last resource being especially important not only for cooking but also in the smoking of salt-cured buffalo meat.

A final attribute of any campsite was the presence of abundant game, apparently desirable when hunters tired of buffalo meat. Cook (1907:114) further described his camp near Double Mountain as being "in a veritable hunters' paradise. There were buffalo, antelope, deer, and as one of the party remarked, 'turkey until further orders'."

Because buffalo herds were rapidly decimated, camps were moved frequently. As a result, time was not always taken to build permanent or even temporary shelters. However, 
TABLE 4

BUFFALO HUNTING CAMPS

\begin{tabular}{|c|c|c|c|c|c|c|}
\hline Reference & $\begin{array}{l}\text { Location } \\
\text { (County, Town) }\end{array}$ & River/Creek & Camp Type & Occupant (s) * & Date & $\begin{array}{l}\text { Probable } \\
\text { Point } \\
\text { of Supply }\end{array}$ \\
\hline $\begin{array}{l}\text { Gard 1959a:107 } \\
\text { Rathjen 1973:166 }\end{array}$ & Hansford & Palo Duro Creek & $\begin{array}{l}\text { dugout with } \\
\text { cottonwood } \\
\text { pole corral }\end{array}$ & $\begin{array}{l}\text { Bob and Jim Cator } \\
\text { - }\end{array}$ & Fall 1872 & Dodge City \\
\hline Rathjen 1973:156 & $\begin{array}{l}\text { ca. } 18 \text { miles } \\
\text { above old } \\
\text { Bent's Fort }\end{array}$ & Canadian River & -- & $\begin{array}{l}\text { J. Wright Mooar and } \\
\text { John W. Mooar }\end{array}$ & Sept. 1873 & Dodge City \\
\hline Rathjen 1973:156 & Hansford & Palo Duro Creek & -- & $\begin{array}{l}\text { J. Wright Mooar and } \\
\text { John W. Mooar }\end{array}$ & $\begin{array}{l}\text { Winter 1873- } \\
1874\end{array}$ & Dođge City \\
\hline Gard 1959a:135 & Hansford & $\begin{array}{l}\text { Palo Duro Creek } \\
\text { ( } 6 \text { miles upstream } \\
\text { from Mooars) }\end{array}$ & - & Lane and Wheeler & $\begin{array}{l}\text { Winter 1873- } \\
1874\end{array}$ & Dodge City \\
\hline Gard 1959a:159 & Texas Panhandle & Chicken Creek & -- & $\begin{array}{l}\text { Dave Dudley and } \\
\text { Tommy Wallace }\end{array}$ & 1874 & Dođge City \\
\hline Gard 1959a:159 & $\begin{array}{l}\mathrm{N} \text { of present- } \\
\text { day Clarendon }\end{array}$ & Salt Fork & -- & Anderson Moore & 1874 & Dodge City \\
\hline $\begin{array}{l}\text { Rathjen 1973:168 } \\
\text { Gard 1959a:193 }\end{array}$ & $\begin{array}{l}6 \text { miles } \mathrm{NE} \text { of } \\
\text { present-day } \\
\text { Haskell }\end{array}$ & -- & -- & $\begin{array}{l}\text { Joe S. McCombs, } \\
\text { John Jacobs, and } \\
\text { John Poe }\end{array}$ & $\begin{array}{l}\text { Jan.-Feb. } \\
1874\end{array}$ & Fort Griffin \\
\hline
\end{tabular}

*Name given is for hunter; a full complement of skinners and other camp personnel is presumed to have been present as well. 
Table 4, continued

Probable

\begin{tabular}{|c|c|c|c|c|c|c|}
\hline Reference & $\begin{array}{l}\text { Location } \\
\text { (County, Town) }\end{array}$ & River/Creek & Camp Type & Occupant (s) & Date & $\begin{array}{l}\text { Probable } \\
\text { Point } \\
\text { of Supply }\end{array}$ \\
\hline Gard 1959a:158, 190 & $\begin{array}{l}\mathrm{S} \text { of Canadian } \\
\text { River }\end{array}$ & Canadian River & -- & J. Wright Mooar & Spring 1874 & Dodge City \\
\hline Gard 1959a:158, 190 & Texas Panhandle & -- & -- & Cox and Frazier & Spring 1874 & Dodge City \\
\hline Gard 1959a:158, 190 & Texas Panhandle & -- & -- & Galloway and Sisk & Spring 1874 & Dodge City \\
\hline Gard 1959a:142 & -- & $\begin{array}{l}\text { Grapevine Creek } \\
\mathrm{N} \text { of the } \\
\text { Canadian River }\end{array}$ & -- & $\begin{array}{l}\text { Billy Dixon } \\
\text {. }\end{array}$ & Spring 1874 & Dodge City \\
\hline Gard 1959a:158, 190 & Carson? & Dixon Creek & -- & Billy Dixon & May 1874 & Dodge City \\
\hline $\begin{array}{l}\text { Baker and Harrison } \\
1986: 34-35\end{array}$ & -- & $\begin{array}{l}\text { Gageby Creek near } \\
\text { Middle Washita } \\
\text { River }\end{array}$ & -- & J. Wright Mooar & May 1874 & Dodge City \\
\hline Gard 1959a:142 & $\because$. & $\begin{array}{l}\text { between Big Creek } \\
\text { and Bugbee Canyon } \\
\text { on Canadian River }\end{array}$ & - & Billy Dixon & May 1874 & Dodge City \\
\hline $\begin{array}{l}\text { Baker and Harrison } \\
\text { 1986:35 }\end{array}$ & -- & $\begin{array}{l}\text { Salt Fork of } \\
\text { the Red River }\end{array}$ & -- & $\begin{array}{c}\text { J. Wright Mooar } \\
\text {.. }\end{array}$ & $\begin{array}{l}\text { May-June } \\
1874\end{array}$ & Dodge City \\
\hline Gard 1959a:184 & $\begin{array}{l}\text { ca. } 20 \text { miles } N \\
\text { of Fort Griffin }\end{array}$ & Elm Creek & -- & Bussell brothers & Fall 1874 & Fort Griffin \\
\hline Gard 1959a:189 & Buffalo Gap & -- & -- & 6 men from Comanche & Fall 1874 & Fort Griffin \\
\hline
\end{tabular}


Table 4, continued

Probable

\begin{tabular}{|c|c|c|c|c|c|c|}
\hline Reference & $\begin{array}{l}\text { Location } \\
\text { (County, Town) }\end{array}$ & River/Creek & Camp Type & Occupant (s) & Date & $\begin{array}{l}\text { Probable } \\
\text { Point } \\
\text { of Supply }\end{array}$ \\
\hline Gard 1959a:189-190 & near Brownwood & -- & $\begin{array}{l}\text { pole huts } \\
\text { covered with } \\
\text { buffalo skins } \\
\text { and having } \\
\text { hide floors }\end{array}$ & -- & Fall 1874 & Dodge City \\
\hline $\begin{array}{l}\text { Baker and Harrison } \\
1986: 110\end{array}$ & near Adobe Walls & Canadian River & -- & $\begin{array}{l}\text { George A. Simpson } \\
\text { and family }\end{array}$ & Dec. 1874 & Dodge City \\
\hline Gard 1959a:194 & $\begin{array}{l}\text { present-day } \\
\text { Haskell County }\end{array}$ & $\begin{array}{l}\text { Paint Creek near } \\
\text { Mockingbird } \\
\text { Springs }\end{array}$ & -- & $\begin{array}{l}\text { Poe, Jacobs, and } \\
\text { McCombs }\end{array}$ & $\begin{array}{l}\text { Winter } \\
1874-1875\end{array}$ & Dodge City \\
\hline Gard 1959a:166 & $\mathrm{N}$ of Mobeetie & Gageby Creek & -- & $\begin{array}{l}\text { John Woods and } \\
\text { George Simpson }\end{array}$ & 1875 & Dodge City \\
\hline Gard 1959a:166 & $\begin{array}{l}10 \text { miles } \mathrm{S} \text { of } \\
\text { Mobeetie }\end{array}$ & -- & -- & $\begin{array}{l}\text { John Woods and } \\
\text { George Simpson }\end{array}$ & [1875?] & Dodge City \\
\hline Gard 1959a:166 & $\begin{array}{l}\text { eastern } \\
\text { Panhandle }\end{array}$ & - & -- & $\begin{array}{l}25 \text { outfits of } \\
6 \text { men each }\end{array}$ & [1875?] & Dodge City \\
\hline Branch 1929:201 & -- & $\begin{array}{l}\text { fresh spring } \\
\text { near Salt Fork } \\
\text { of the Brazos }\end{array}$ & -- & Charles Hart & 1875 & Fort Griffin \\
\hline Gard 1959a:203 & - & $\begin{array}{l}\text { head of } \\
\text { Colorado River }\end{array}$ & $\begin{array}{l}\text { pole house } \\
\text { ca. 8-10 ft } \\
\text { wide and } \\
\text { "real long," } \\
\text { covered with } \\
\text { green hides } \\
\text { with S side } \\
\text { open }\end{array}$ & Frank Sherrod & 1875 & Fort Griffin \\
\hline
\end{tabular}


Table 4, continued

\begin{tabular}{|c|c|c|c|c|c|c|}
\hline Reference & $\begin{array}{l}\text { Location } \\
\text { (County, Town) }\end{array}$ & River/Creek & Camp Type & Occupant (s) & Date & $\begin{array}{l}\text { Probable } \\
\text { Point } \\
\text { of Supply }\end{array}$ \\
\hline Gard 1959a:202 & $\begin{array}{l}\text { near foot of } \\
\text { Staked Plains }\end{array}$ & $\begin{array}{l}\text { between Little } \\
\text { Duck and } \\
\text { Stinking creeks }\end{array}$ & -- & George Causey & 1875 & Dodge City \\
\hline $\begin{array}{l}\text { Baker and Harrison } \\
\text { 1986:110 }\end{array}$ & -- & Red Deer Creek & -- & George $\mathrm{W}$. Brown & Feb. 1875 & Dodge City \\
\hline $\begin{array}{l}\text { Baker and Harrison } \\
\text { 1986:110 }\end{array}$ & Adobe Walls & Canadian River & -- & $\begin{array}{l}\text { George Bellfield } \\
\text {. }\end{array}$ & $\begin{array}{l}\text { ca. March } \\
1875\end{array}$ & Dodge City \\
\hline Gard 1959a:39 & $\begin{array}{l}\text { present-day } \\
\text { Weinert }\end{array}$ & Mule Creek & -- & $\begin{array}{l}\text { J. Wright Moor } \\
\text { and John Mooar }\end{array}$ & $\begin{array}{l}\text { Spring-Nov. } \\
1875\end{array}$ & Fort Griffin \\
\hline Gard 1959a:203 & $\begin{array}{l}\text { near present- } \\
\text { day Colorado } \\
\text { City }\end{array}$ & Champion Creek & -- & Joe McCombs & Spring 1875 & Fort Griffin \\
\hline Gard 1959a:167 & $\begin{array}{l}\mathrm{S} \text { of present- } \\
\text { day Clarendon }\end{array}$ & $\begin{array}{l}\text { near mouth of } \\
\text { Mulberry Creek }\end{array}$ & -- & Richard Bussell & $\begin{array}{l}\text { May-June } \\
1875\end{array}$ & Dodge City \\
\hline Anonymous 1928:451 & $\begin{array}{l}\text { present-day } \\
\text { Haskell County }\end{array}$ & Twin Lakes & -- & $\begin{array}{l}\text { J. Wright Mooar and } \\
\text { John W. Mooar, Jim } \\
\text { White, Bill Russell, } \\
\text { and Mike O'Brien }\end{array}$ & Fall 1875 & Fort Griffin \\
\hline Gard 1959a:203 & $\begin{array}{l}\text { present-day } \\
\text { Sweetwater, } \\
\text { Nolan County }\end{array}$ & -- & -- & Joe McCombs & Winter 1875 & Fort Griffin \\
\hline Gard 1959a:222-223 & Randall County & $\begin{array}{l}\text { above Palo Duro } \\
\text { Canyon }\end{array}$ & -- & $\begin{array}{l}\text { Mr. and Mrs. } \\
\text { Robert Truby }\end{array}$ & ca. 1876 & Dodge City \\
\hline
\end{tabular}


$\underline{\text { Table 4, continued }}$

\begin{tabular}{|c|c|c|c|c|c|c|}
\hline Reference & $\begin{array}{l}\text { Location } \\
\text { (County, Town) }\end{array}$ & River/Creek & Camp Type & Occupant (s) & Date & $\begin{array}{l}\text { Probable } \\
\text { Point } \\
\text { of Supply }\end{array}$ \\
\hline Gard 1959a:167 & - & Quitaque [Creek] & -- & Richard Bussell & $\begin{array}{l}\text { Spring } \\
1876-1879\end{array}$ & Dodge City \\
\hline Woody $1926: 1,1928: 1$ & $\begin{array}{l}\text { present-day } \\
\text { Garza County, } \\
\text { ca. } 8 \text { miles S } \\
\text { of Post, at } \\
\text { Woody Peak in } \\
\text { an "Indian town" }\end{array}$ & $\begin{array}{l}\text { Double Mountain } \\
\text { Fork of Brazos } \\
\text { River }\end{array}$ & $\begin{array}{l}\text { dugout with } \\
\text { a rock } \\
\text { chimney }\end{array}$ & $\begin{array}{l}\text { Woody Brothers and } \\
\text { Raymond Rump [Rumph] } \\
\text {. }\end{array}$ & $\begin{array}{l}\text { Oct. 10, } \\
1876- \\
\text { Fall } 1877\end{array}$ & Fort Griffin \\
\hline Gard 1959a:251 & $\begin{array}{l}\text { present-day } \\
\text { Scurry County }\end{array}$ & Deep Creek & -- & $\begin{array}{l}\text { J. Wright Mooar } \\
\text { and John W. Mooar }\end{array}$ & $\begin{array}{l}\text { Fall 1876, } \\
\text { Winter } \\
1877-1878\end{array}$ & Fort Griffin \\
\hline Gard 1959a:230 & $\begin{array}{l}\text { divide W of } \\
\text { Colorado City }\end{array}$ & Morgan Creek & -- & Joe S. McCombs & $\begin{array}{l}\text { Winter } \\
1876-1877\end{array}$ & Fort Griffin \\
\hline Gard 1959a:230 & Tom Green County & $\begin{array}{l}\text { Middle Concho } \\
\text { River }\end{array}$ & dugout & Windy Bill Russell & $\begin{array}{l}\text { Winter } \\
1876-1877\end{array}$ & Fort Griffin \\
\hline Gard 1959a:251 & Big Spring & -- & -- & Joe-S. McCombs & Fall 1877 & Fort Griffin \\
\hline Woody 1926:3 & -- & $\begin{array}{l}\text { spring at head } \\
\text { of North Concho } \\
\text { River }\end{array}$ & -- & $\begin{array}{l}\text { J. W., A. B., and } \\
\text { D. P. Woody and } \\
\text { Raymond Rumph }\end{array}$ & $\begin{array}{l}\text { Winter } 1877- \\
\text { Spring } 1878\end{array}$ & Fort Griffin \\
\hline Gard 1959a:251 . & $\begin{array}{l}\text { N of McCombs' } \\
\text { Signal Mountain } \\
\text { camp }\end{array}$ & -- & -- & $\begin{array}{l}\text { John Jacobs, John W. } \\
\text { Poe; several other } \\
\text { outfits }\end{array}$ & $\begin{array}{l}\text { Winter } \\
1877-1878\end{array}$ & Fort Griffin \\
\hline
\end{tabular}


Table 4, continued

Probable

\begin{tabular}{|c|c|c|c|c|c|c|}
\hline Reference & $\begin{array}{l}\text { Location } \\
\text { (County, Town) }\end{array}$ & River/Creek & Camp Type & Occupant (s) & Date & $\begin{array}{l}\text { Probable } \\
\text { Point } \\
\text { of Supply }\end{array}$ \\
\hline Dumont $1988: 23$ & Rolling Plains & $\begin{array}{l}\text { big spring at } \\
\text { head of creek } \\
\text { leading back to } \\
\text { Wichita River }\end{array}$ & $\begin{array}{l}\text { little rock } \\
\text { house; tepee } \\
\text { built of } \\
\text { china pole } \\
\text { frame, raw- } \\
\text { hide strings, } \\
\text { and dried } \\
\text { buffalo hides, } \\
\text { and having } \\
\text { rock chimney } \\
\text { with fire- } \\
\text { place and } \\
\text { buffalo hide } \\
\text { carpet }\end{array}$ & $\begin{array}{l}\text { Ellen and Tom Bird, } \\
\text { ? Jones }\end{array}$ & $\begin{array}{l}\text { Dec. } 1877- \\
\text { Jan. } 1878\end{array}$ & Fort Griffin \\
\hline Gard 1959a:251 & $\begin{array}{l}10 \text { miles } S \text { of } \\
\text { Big Spring near } \\
\text { Signal Mountain }\end{array}$ & $\begin{array}{l}\text { Mossy Rock } \\
\text { Springs }\end{array}$ & -- & Joe S. McCombs & Spring 1878 & Fort Griffin \\
\hline $\begin{array}{l}\text { Rathjen 1973:169 } \\
\text { Gard 1959a:253 }\end{array}$ & $\begin{array}{l}\text { near present-day } \\
\text { Midland }\end{array}$ & Mustang Pond & -- & Joe S. McCombs & $\begin{array}{l}\text { Sept. } 1878- \\
\text { March } 1879\end{array}$ & Fort Griffin \\
\hline Cook 1907:114 & breaks & $\begin{array}{l}\text { Salt Fork of the } \\
\text { Brazos at a fresh } \\
\text { spring of water }\end{array}$ & -- & John R. Cook & -- & Fort Griffin \\
\hline Cook 1907:114 & $\begin{array}{l}25 \text { miles } W \text { of } \\
\text { 100th meridian, } \\
\text { W of Kiowa Peak } \\
\text { and N of Double } \\
\text { Mountain }\end{array}$ & $\begin{array}{l}\text { Salt Fork of } \\
\text { the Brazos }\end{array}$ & -- & John R. Cook & -- & Fort Griffin \\
\hline
\end{tabular}


Table 4, continued

\begin{tabular}{|c|c|c|c|c|c|c|}
\hline References & $\begin{array}{l}\text { Location } \\
\text { (County, Town) }\end{array}$ & River/Creek & Camp Type & Occupant (s) & Date & $\begin{array}{l}\text { Probable } \\
\text { Point } \\
\text { of Supply }\end{array}$ \\
\hline Hathaway 1931:129 & -- & $\begin{array}{l}\text { mouth of Blue } \\
\text { Creek }\end{array}$ & $\begin{array}{l}\text { small dugout } \\
\text { in a bank }\end{array}$ & Seth Hathaway & -- & Dodge City \\
\hline Hathaway 1931:129 & $\begin{array}{l}20 \text { miles from } \\
\text { Adobe Walls }\end{array}$ & Palo Duro Creek & dugout & $\begin{array}{l}\text { Newell, his } 2-3 \\
\text { outfits, and his } \\
\text { Mexican wife }\end{array}$ & -- & Dodge City \\
\hline Cook 1907:114 & -- & $\begin{array}{l}\text { tributary of } \\
\text { Pease River }\end{array}$ & -- & $\begin{array}{l}\text { John R. Cook, Carr } \\
\text { and Causey, Joe } \\
\text { Freed, John Godey, } \\
\text { Uncle Joe Horde, } \\
\text { Hiram Bickerdyke }\end{array}$ & - & Dodge City \\
\hline Cook 1907:143 & & $\begin{array}{l}\text { a tributary of } \\
\text { the Salt Fork of } \\
\text { the Brazos coming } \\
\text { in from the } \mathrm{S} \\
\text { side }\end{array}$ & . & Hiram Bickerdyke & -- & Fort Griffin \\
\hline Gard 1959a:191 & $\begin{array}{l}\text { Present-day } \\
\text { Dickens County }\end{array}$ & Duck Creek & - & Causey brothers & -- & Dodge City [?] \\
\hline
\end{tabular}


in cases where hunters anticipated returning to the camp, where herds appeared to be so large that it would take several months to kill all the animals, or when hunting occurred during the winter months, some kind of shelter might be erected.

Descriptions of their camps by buffalo hunters suggest that shelter consisted of three different types of structures. The first of these was the dugout, exemplified by the Cator brothers' shelter on Palo Duro Creek which had a cottonwood pole corral adjacent to it (Gard 1959a:107). Seth Hathaway (1931:129) described his outfit's shelter at the mouth of Blue Creek as having been a small dugout excavated into a bank, while in Douglas Branch's (1929:162) opinion, "the only kind of a dugout worth having was one with a big, open fireplace, near the edge of a stream with good water, with plenty of wood on its banks." Woody and Rumph's 1876-1877 permanent camp in present-day Garza County was a dugout with a rock chimney which they constructed in the midst of an abandoned Indian camp containing 172 tepees made of poles and covered with grass (Woody 1926:1, 1928:1).

A second type of structure used by buffalo hunters was the hide or pole house, one example of which was built by Frank Sherrod and his crew in 1875 at the head of the Colorado River. As Sherrod described it: "We cut forked poles, placed them in the ground, and covered them with green hides. We made our house eight or ten feet wide and real long, with the south side open. When we built a fire in front, we were warm inside" (Gard 1959a: 203).

The most common shelter was the tepee which Ella Bird Dumont, the wife of a buffalo hunter, described as having a frame built of small chinaberry poles with other poles for rafters.

No nails were used, but rawhide strings instead. We took dried buffalo hides, tied the legs together, and put them around the wall, woolside out. Then another tier of hides was placed over these in the same like manner to break the joints of those underneath. The roof was made on the same like order as the walls, tying down the legs all around the edges. The door was made of a frame of split poles with a buffalo hide stretched over it, legs tied inside. The little rock chimney with fireplace, which was crude, of course, came next. The floor was carpeted with buffalo hides squared-up to fit, woolside up. All was complete, and a more clean and comfortable little home you could not find in any of the eastern cities. The furniture was homemade of the crudest kind. We had no use for anything then but a camping outfit.

In this little home we lived very happily indeed. We cooked on the fireplace and ate our meals in front of the fire, sitting campfashion on the floor, which was carpeted with buffalo hides [Dumont 1988:24].

\section{Acquisition of the Product}

Acquisition of the buffalo product was a multistage process which was as well-defined, structured, and organized as the buffalo trade itself. Beginning with the organization of 
each hunting party and concluding with the transportation of buffalo meat and hides to railheads and commercial markets, the acquisition of the product was a business the profitability of which depended not only on the availability of a superabundant resource but also on the ability of the buffalo hunters to harvest the resource quickly and efficiently.

Hunting

The development of efficient hunting methods evolved quickly after demand for the buffalo product increased. Initially, men hunted from horseback, shooting the animals while running beside them or shooting from the rear, a method that was termed tail shooting. While these methods were exciting, hunters soon learned that they also were inefficient, for at the day's end the carcasses were strung out for distances of a mile or more. Such practices constituted "tenderfoot" hunting (Glenn 1949:20-21; Gard 1959a:117; Haines 1975:191), and participants soon realized that "it was not always the best shot but the best hunter that succeeded, that is, the man who piled his buffalo in a pile so as to be convenient for the skinner to get at and not have to run all over the country" (Glenn 1949:22).

The mechanism for "piling up the buffalo" was the stand, a technique perfected on the Kansas plains and utilized widely in Texas. A hunter initiated a stand by starting out in the morning on horseback until a herd was located. The hunter then approached on foot, concealing himself, and stopping no more than 150 to 350 yards from the buffalo. Because of the weight of his gun, the shooter would then usually position it on forked sticks after laying his cartridges on the ground nearby. However, some hunters shot from a sitting position; J. Wright Mooar shot while kneeling, sitting down and resting both elbows on his knees, or lying flat on his stomach with his elbows spraddled (Hathaway 1931:111; Glenn 1949:21; Gard 1959a:3-4, 118, 122; Haines 1975:192).

When they began to fire, many hunters identified the leader of the herd and shot that animal first. An attempt usually was made to place the shot through the lungs or in the spine near the hips so that the animal would hump up, walk around, and perhaps lie down. The smell of blood generally disturbed the rest of the herd which would mill around (Branch 1929:165; Hathaway 1931:111; Gard 1959a:118, 121; Dumont 1988:25). According to Glenn $(1949: 21-22)$ :

The other buffalo sniffing the blood and following would not be watching the hunter, and he would continue to shoot the outside cow buffalo; if there were old cows they would take them as there would be some two or three offsprings following her. If she would hump up, he would know that he had the range, and in this way hold the herd as long as they acted in this way as well as the well trained cowpuncher would hold his herd, only the hunter would use his gun. This was termed mesmerising [sic] the buffalo so that we could hold them on what we termed a stand, which afterwards proved to be the most successful way of killing the buffalo.

As many as 100 or more animals could be shot in one episode by using the stand method. One chronicler claimed to have counted 112 bodies in a 200-yard radius, all killed by one hunter in less than 45 minutes (Rathjen 1973:171). Stands of 10 to 50 animals were more 
nearly the norm (Hathaway 1931:111) with the size depending largely on the numbers of animals in the herd and the skill of the hunter.

Skinning

Following the successful conclusion of a stand, the hunter signaled to his skinners who then arrived with wagons for transporting the hides and meat back to camp. Although some skinners were so skilled that they could skin 60 buffalo in one day (Dumont 1988:31), the average was considerably less since the work was hard, slow, and dirty.

Some skinners tried to lessen the effort in skinning by using draft animals to help pull the hide from the carcass. Too often, however, a chunk or two of flesh tore, ruining the hide. A more successful method entailed taking a stick the size of a chair post. The skinner then got down on his knees under the foreshoulder of the buffalo and pushed the carcass up on its back so that the feet were sticking straight up in the air. He then pushed one end of the stick into the ground and the other end into the body below the brisket so that the buffalo was held stationary on its back (Glenn 1949:29; Dumont 1988: 31).

With the carcass stabilized, the skinner would cut open the body from the underjaw to the root of the tail. He also cut a line from the hind foot to the tail and from the front hoof over the knee to below the brisket. These cuts resulted in a hide that could be stretched uniformly.

After completing the cuts, the skinner peeled the hide off, beginning with the jaw and running back to the neck. When he had peeled the hide over the backbone, the skinner would go to the other side and skin the two front legs down.

After the top half of the carcass was peeled, the skinner would remove the stick that held the buffalo on its back. Then, if everything had been done correctly and the hide had been shoved underneath the body as the skinner worked, the skinner would pull the hide off the rest of the way (Glenn 1949:30).

Folding and Loading

After the skin was removed, the skinner spread it on the ground, rolled the legs under, and wrapped the sides in. He then started at the jaw and rolled the skin up to the tail, and taking it by the tail, threw it into the hide wagon (Glenn 1949:30).

Pegging and Drying

Upon arrival at camp, the fresh skins were unloaded, unrolled, and spread flat on the ground. Small holes were cut along the edges of each hide which was stretched and attached to the ground with stout wooden pegs measuring approximately $1 / 2$ to 1 inch square and 6 to 8 inches long. Excess flesh was scraped from the underside of the hide which was left to 
dry several days before being turned. Each side was sprinkled with arsenic to deter bugs (Cook 1907:117; Branch 1929:168; Hathaway 1931:110-111; Glenn 1949:32; Gard 1959a:127; Dumont 1988:32).

\author{
Organizing and Classifying
}

After the skins were thoroughly dried and ready for market, the pegs were removed. Camp members then classified the hides as they piled them up, separating bulls and cows. Robe hides were placed in another pile, and hides of younger animals were put into what was called the kip pile (Cook 1907:117). Glenn (1949:28) pointed out that the classifiers' actions were governed by the weight and size of the robe as well as the sex so that cow hides that were unusually heavy (30 to 50 pounds) would be placed on the bull pile.

\title{
Folding and Stacking
}

Some freighters folded the dry hides or loaded them on the wagons flat. But the more general practice was to bend the hides in the middle with the hair side in and build square piles on the ground. A large flat hide was then put over the top of each pile and dirt or rocks sometimes thrown on top to keep the hides from blowing away, to make them smoother, and to compress them so they would occupy less space in the hide wagons (Hathaway 1931:112; Glenn 1949:28; Gard 1959a:127; Haines 1975:193).

When a pile of hides was about 8 feet high, stringers were cut from a green hide. These were threaded through the peg holes in the corners of the hides located at the bottom and the top of the hide pile, drawn down tightly, and tied. A full wagon load might be comprised of 35 to 50 packs of 10 skins each and could weigh as much as 8,000 to 9,000 pounds (Cook 1907:117; Branch 1929:168; Gard 1959a:127; Haines 1975:193).

$$
\text { Butchering, Curing, Smoking }
$$

Meat was the second product of the buffalo hunt, and it was treated in a number of ways to prepare it for market. The most desirable body parts, aside from the hide, were the hump, tongue, and tallow. In some cases, it was the responsibility of the hunter to remove those parts; regardless of who performed the task, it had to be done while the buffalo was fresh, for a carcass left for only one day often became what was called a stinker (Glenn 1949:24).

The hump, which was the largest piece of meat removed, was comprised of the flesh which grew between the buffalo's bones from the root of the shaggy foretop to the back of the loin. Removal of this meat, which often was 3 feet long and as much as 10 to 12 inches wide and 4 to 5 inches thick near the front of the ribs, was accomplished by cutting the flesh down the side of the blade bone until it dropped down. The hunter then started cutting the meat on the ribs and peeled it back toward the backbone. This substantial chunk of meat was loaded onto the meat wagon together with the tongues, tallow, and hams which had been taken from the area of the hip joints (Cook 1907:85; Glenn 1949:26, 38). 
After the meat was taken to camp, it was unloaded and further prepared by the butcher or meat man. This individual took the hump and hindquarters and cut out as many as three large pieces from each part, some resembling the ham of a hog. These were trimmed so that they would have a nice appearance for the market (Glenn 1949:38; Haines 1975:194).

Curing of the hams, humps, and tongues required the construction of a brine pit, a round depression about 4 feet deep and sufficiently large to handle up to 1,000 pounds of meat. The pit was lined with a fresh green hide which was secured to the outside ground surface by pegging. The meat was salted and placed into the pit in water that had been bolled and then cooled to about blood heat. Finally, a hide was stretched over the top of the pit and pegged down to keep dirt and dust out of the brine solution (Glenn 1949:38-39; Gard 1959a:123; Haines 1975:194).

After seven or eight days, the men removed the meat and washed it. It was then placed in a smokehouse. In some cases, this structure was made of poles and hides in which a small fire pit was located (Gard 1959a:123). In other cases, the men dug into the bank of a steep ravine, lined the space with hides so that it was smoke tight, and hung the meat in it. A trench 8 to 10 feet long was dug outside the smokehouse and covered with poles and dirt. A fire was built in the trench so that the meat was not touched by flame but only by the smoke generated by the fire in the trench (Glenn 1949:39; Gard 1959a:123).

At the conclusion of the curing process, the camp butcher packed the tongues in barrels for shipment; each piece of hump and ham was sewn into a tight-fitting canvas wrapper. The meat was readily sold in the eastern markets where it brought from 20 to 30 cents per pound (Glenn 1949:39; Haines 1975:194-195).

\section{Transportation to Markets/Freighting}

Transportation of the buffalo product from the camp to distant merchants was accomplished in one of two ways. Often, designated members of the hunting parties would load the groups' wagons and set off to the nearest market in caravans including as many as 18 teams of six yokes of animals, each team drawing three wagons. Caravans from Fort Griffin to Dallas might contain as many as 40 wagons, each drawn by six or eight mules or oxen. If the caravan originated in the Rolling Plains, it generally headed for Rath City near Double Mountain, Fort Griffin on the Clear Fork of the Brazos, or even Fort Worth. Panhandle hunters usually hauled their hides and meat to Hidetown near Fort Elliott, after which the product was taken north in wagons to towns in southern Kansas located on the Santa Fe Railroad (see Fig. 2) (Gard 1959a:127, 200, 205; Dumont 1988:24, 168).

Hides and meat transported to market generally brought a higher price for the hunter, but some preferred to sell the buffalo product in the camp itself to buyers. The buyers, who represented merchants in Colorado City, Fort Griffin, San Antonio, Fort Worth, and other major retail centers, toured the camps, purchasing hides and meat in the field and assuming the responsibility of transporting the product by wagon and ox team (Glenn 1949: 39; Dumont 1988:162). 
Livestock Feeding and Bone Collecting

While harvesting of buffalo meat and skins was the main activity associated with buffalo hunting, two peripheral activities were spawned by the fact that the hunt resulted in an enormous amount of meat and bone waste. The first of these activities was a minor one and occurred in the late 1870s when a group of farmers in eastern Texas drove a large herd of hogs to the buffalo range where the farmers participated in the hunt and fattened their hogs on the carcasses. According to Gard (1959a:234), they then "drove the hogs back to their homes in the pine-woods country and slaughtered them. Never had they taken better pork to market."

A more important and widespread activity which occurred during and for many years after the buffalo hunt involved the collection of buffalo bones. This business occurred throughout the Great Plains and Southern Plains in response to a demand from industrial plants for phosphates used in the production of fertilizer and carbon used in the refinement of sugar. By the early 1870s, railroads were carrying millions of pounds of buffalo bones, and in 1880 a freight train from Abilene, Texas, to New Orieans, Louisiana, carried nothing but bones. Haulers flocked to the Rolling Plains and the Panhandle where they competed with farming families and former buffalo hunters like John Mooar, who earned more than $\$ 1,500$ for bones he collected on trips to Charles Goodnight's ranch on the Quitaque and sold in Colorado City (Branch 1929:221-223; Gard 1959b:45).

Buffalo Hunting on the Rolling Plains, 1874-1879

The Rolling Plains of Texas, an area located west of the Cross Timbers and east of the Caprock, was one of the last localities in Texas in which commercial buffalo hunting occurred. However, because the herds were still numerous in the area as late as 1875, buffalo hunting was a significant factor in the economic development of the Rolling Plains. Surrounding trade centers such as Fort Griffin, Dallas, Fort Worth, and Denison derived much of their prosperity from the marketing of the buffalo product, while the hunters who decimated the herds represented the vanguard of Anglo-American presence in West Texas. As Rathjen (1973:175) pointed out:

Absence of the buffalo . . cleared the way for subsequent development of the.. region. With the buffalo gone, grass was available for cattle. - . In the longer range, the way also was prepared for the farmer, since there can be no doubt that significant numbers of wild buffalo are incompatible with any enterprise that required fencing.

Exploitation of the buffalo resource in the area of the Rolling Plains lying within present-day Stonewall, Kent, and King counties began in 1875 when parties of hunters left Fort Griffin and established numerous camps along the Double Mountain and Salt Forks of the Brazos River (see Fig. 2). John R. Cook and Ella Bird Dumont both occupied hunting camps, such as the one located at 41KG61 near Salt Croton Creek (Thurmond et al. 1981:371, 376), and described other numerous outfits which were located in the area. Cook's own first camp was located in the gypsum breaks of Croton Creek within sight of Kiowa Peak and Double Mountain, where he and his five companions killed 3,361 animals in three months. Outfits located in the same general area in 1875 included those of Carr and Causey, which killed 
3,700 buffalo; John Goff; and the Quinn Brothers at whose camp a Leavenworth, Kansas, hide buyer bought ca. 12,000 buffalo hides gathered during the winter of 1875-1876 (Thurmond et al. 1981:374). Other outfits sold hides and meat at Rath City located only a short distance southeast in Stonewall County on the Double Mountain Fork of the Brazos River.

The peak of buffalo hunting in the vicinity of Double Mountain occurred in 1875-1877, during which period the hunters apparently began to look west to Garza, Scurry, and Borden counties for more hides. In 1876, J. Wright Mooar with his brother, John, left Fort Griffin and traveled up the Brazos River to present-day Scurry County. They set up a camp on Deep Creek which remained their hunting headquarters until 1878 (Anonymous 1928:452; Gard 1959b:40, 44; Anderson 1974:76). The new hunting grounds apparently were a sufficient distance from Rath City to justify the establishment of two new trading posts. According to local historian Edna Miller, one of these posts was located in western Borden County and was operated by Pete Snyder (Miller 1988). Another store was owned and operated by H. T. "Tuck" Cornelius, and it was located about 10 miles east of the Mooars' campsite. This second store was acquired by Snyder in the spring of 1878 when he realized that the buffalo had all but disappeared and a store on the Mackenzie Trail might be more profitable in the future as cattlemen began to move their, herds into the area (Anderson 1984:53, 56-58, 62). In the meantime, according to hunter J. W. Woody, "Pete Snyder kept everything that the hunters would need, but ammunition was the main thing." He also kept an ox team of four to five yoke of steers which he kept continuously on the road to Fort Worth and San Antonio and back. He apparently competed with the local freighters who were numerous in the area and visited the camps where they picked up hides and meat, later delivering the products to Fort Griffin (Woody 1926:1, 3, 1928:1-3).

The Mooars were the best known of the hunters in the Scurry County and Garza County areas. They also must have been extremely successful in their hunting, judging from the smokehouse they constructed at their camp which measured over 100 feet long and 20 feet wide (Anderson 1974:79). Other hunters who met with considerable success between October 1876 and the summer of 1878 were J. W. and A. B. Woody and Raymond and Mat Rump [Rumph], who pitched their first buffalo camp at the head of Bull Creek before making a permanent camp approximately 8 miles south of present-day Post. According to Woody (1926:1), the greatest number of hunters were present in the area in 1876-1877 and most of the killing occurred from the Yellowhouse River on the north to Muchaway (Mucho-que) Peak in presentday Borden County.

By the end of 1877, it was clear to most hunters in the area of the Double Mountain Fork of the Brazos River that the buffalo herds had almost disappeared (Anderson 1974:76). Sporadic hunting occurred during the winter of 1878-1879 when the Mooars marketed meat to Colorado City (Gard 1959b:44). But the brothers' interests had turned to other economic pursuits out of necessity. They became increasingly involved in the operation of their ranch on Cottonwood Creek which they had stocked with 500 head of cattle purchased from John Goff near Double Mountain (Anderson 1974:75). By doing so, the Mooars made the transition from the perlod of maximum resource exploitation to the era of agricultural development on the Rolling Plains. 
THE LONE BUFFALO HUNTER

It's of those Texas cowboys, a story I'll tell;

No name I will mention though in Texas they do dwell.

Go find them where you will, they are all so very brave,

And when in good society they seldom misbehave.

When the fall work is all over in the line-camp they'll be found, For they have to ride those lonesome lines the long winter round; They prove loyal to a comrade, no matter what's to do; And when in love with a fair one they seldom prove untrue.

But springtime comes at last and finds them glad and gay; They ride out to the round-up about the first of May; About the first of August they start up the trail, They have to stay with the cattle, no matter rain or hail.

But when they get to the shipping point, then they receive their tens, Straightway to the bar-room and gently blow them in; It's the height of their ambition, so I've been truly told, To ride good horses and saddles and spend the silver and gold.

Those last two things I've mentioned, it is their heart's desire, And when they leave the shipping point, their eyes are like balls of fire. It's of those fighting cattle, they seem to have no fear, A-riding bucking broncos oft is their heart's desire.

They will ride into the branding pen, a rope within their hands, They will catch them by each forefoot and bring them to the sands; It's altogether in practice with a little bit of sleight, A-roping Texas cattle, it is their heart's delight.

But now comes the rising generation to take the cowboy's place, Likewise the corn-fed granger, with his bold and cheeky face; It's on those plains of Texas a lone buffalo hunter does stand To tell the fate of the cowboy that rode at his right hand.

FROM: Cowboy Songs and Other Frontier Ballads (Lomax 1916:119-120). 

From the period of initial settlement in Texas through World War II, agriculture has been the leading economic force with more Texans working in agriculturally related occupations than in any other economic sector. Activities related to agriculture have been landdependent, a fact that has resulted in a diversity of crops, methods of production, markets, and cultural sites relating directly to the diversity of topography, soils, climate, and natural resources in Texas (Table 5).

While cultivated crops such as cotton, cane, wheat, and rice have contributed significantly to the State's economy, the raising of livestock has been a major factor not only in the economy but also in the formation of cultural images. Whether open range or closed range, ranching from the Spanish period to the present day has resulted in the creation of numerous highly visible cultural sites throughout the State. Many of those sites are located west of the Cross Timbers region in the Rolling and Southern plains where plentiful grass, water, and shelter provided the natural resources that resulted in prosperous livestock and stock-farming operations after the disappearance of the last buffalo herds and hostile Indian tribes in the late 1870 s.

\section{Overview of Crop and Livestock Production}

Agriculture has been identified by many scholars as the activity that dominated Texas' economy and society. As early as the seventeenth and eighteenth centuries, the Spanish relied on pastoral industries such as the raising, herding, and marketing of sheep and cattle to solve economic problems resulting from the occupation and maintenance of the frontier. Indeed, "wherever the Spanish approached the frontier, horses, cattle, sheep, and goats became a part of the process of imperial defense and empire building" (Myres 1969:10-11).

The Spanish had introduced livestock to present-day Texas by 1690 when Captain Alonso de León brought cattle, horses, and oxen with his expedition to East Texas to establish Mission San Francisco de los Tejas. In 1716, Don Domingo Ramón brought more oxen and horses together with more than a thousand sheep and goats, an importation that was followed two years later when Don Martín de Alarcón "ordered hogs brought in for breeding [to San Antonio], and much cattle and small livestock, goats as well as sheep . ." (Myres 1969: 11).

After 1721, livestock production was heavily promoted by the Marquez de San Miguel y Aguayo who saw stockraising as a way to make Texas self-supporting. A lack of markets, the existence of restrictive government regulations, and the presence of hostile Indians who constantly drove off Spanish herds prevented the florescence of agriculture in the eighteenth century. The foundation of an agricultural economy had been laid, however, and by 1800 there were three centers of livestock ranching in Texas: Nacogdoches, the Rio Grande Valley south of the Nueces River, and the area from San Antonio eastward to the Guadalupe River and southward to La Bahía (Myres 1969:11, 18-19). 
TABLE 5

SITES ASSOCIATED WITH AGRICULTURE*

\begin{tabular}{|c|c|c|}
\hline Site Name/Number & $\begin{array}{l}\text { Location } \\
\text { (County) }\end{array}$ & $\begin{array}{l}\text { State/National } \\
\text { Designation(s) }\end{array}$ \\
\hline CULTIVATED CROPS & & \\
\hline Frederick August Roesler House & Austin & R.T.H.L. 1977; N.R. 1984 \\
\hline Miller-Curtis House (Curtis Mansion) & Bell & R.T.H.L. 1977; N.R. 1983 \\
\hline $\begin{array}{l}\text { Col. Elifah Sterling Clack Robertson } \\
\text { Plantation }\end{array}$ & Bell & $\begin{array}{l}\text { H.A.B.S. 1936; C.M. 1936; } \\
\text { R.T.H.L. } 1967\end{array}$ \\
\hline $\begin{array}{l}\text { Mission Parkway Historic/Archeological } \\
\text { District (41BX3 through 41BX5, 41BX12, } \\
41 \mathrm{BX} 237 \text { through 41BX260, 41BX278 } \\
\text { through 41BX281) }\end{array}$ & Bexar & N.R. 1975， \\
\hline Espada Aqueduct (41BX269) & Bexar & $\begin{array}{l}\text { H.A.B.S. 1936, 1937; } \\
\text { R.T.H.L. 1962; N.H.L. }\end{array}$ \\
\hline $\begin{array}{l}\text { Norwegian Settlement of Bosque County } \\
\text { (Thematic Group) }\end{array}$ & Bosque & S.M. 1969; N.R. 1983 \\
\hline Durazno Plantation & Brazoria & N.R. 1980 \\
\hline McCroskey Log Cabin (41B077) & Brazoria & N.R. 1975; S.M. 1980 \\
\hline $\begin{array}{l}\text { Varner-Hogg Plantation, Varner-Hogg } \\
\text { State Historical Park (41B0133) }\end{array}$ & Brazoria & $\begin{array}{l}\text { H.A.B.S. 1936; R.T.H.L. } \\
\text { 1964; N.R. } 1980\end{array}$ \\
\hline Luna Jacal & Brewster & N.R. 1974 \\
\hline Sublett Farm-Rancho Estelle & Brewster & H.A.B.S. 1964 ; N.R. 1974 \\
\hline Old Brulay Plantation & Cameron & N.R. 1975 \\
\hline Mathews-Powell House & Cass & R.T.H.L. 1973； N.R. 1977 \\
\hline Gruene Historic District & Comal & N.R. 1975 \\
\hline Continental Gin Company & Dallas & N.R. 1983 \\
\hline
\end{tabular}

*Sites and structures listed are drawn from Steely (1984) for the most part. Historic properties not listed in Steely are included because they are known by the historian and are considered to be unusually good examples of the exploitation of a specific resource.

Abbreviations used include H.A.B.S. (Historic American Buildings Survey), R.T.H.L. (Recorded Texas Historic Landmark), N.H.L. (National Historic Landmark), N.R. (National Register), C.M. (Centennial Marker), T.H.E.S.I. (Texas Historical Engineering Site Inventory), and S.M. (Texas Subject Marker). 
Table 5, continued

$\begin{array}{lll} & \text { Location } & \text { State/National } \\ \text { Site Name/Number } & \text { (County) } & \text { Designation(s) }\end{array}$

Capt. Roderick A. Rawlins House

W. A. Strain House

White-Pool House

Thomas and Katherine Trout House

Mt. Eliza

Schulenburg Cotton Compress

William Neese House

Daniel Webster Kempner House

Algerita Hotel

Post Sanitarium

Braches House/41GZ5

A. G. Steele House

R. B. S. Foster House

Saffold Dam (Starcke Park Dam)

William Lockhart Clayton Summer House

John M. Dorrance House

Old Cotton Exchange

Pillot Building

Merchants and Manufacturers Building

Wunsche Bros. Saloon and Hotel

Mimosa Hall

Fry-Barry House

Dial-Williamson House (Pine Hill Plantation)

Edgemont Plantation

Locust Grove Plantation

Claiborne Kyle Log Cabin

Burleson-Knispel House (Maj. Edward Burleson Homestead)

Charles S. Cock House

Cape House
Dallas

Dallas

Ector

Fannin

Fayette

Fayette

Fayette

Galveston

Garza

Garza

Gonzales

Grimes

Grimes

Guadalupe

Harris

Harris

Harris

Harris

Harris

Harris

Harrison

Harrison

Harrison

Harrison

Harrison

Hays

Hays

Hays

Hays
R.T.H.L. 1964; N.R. 1978

R.T.H.L. 1977; N.R. 1978

R.T.H.L. 1980; N.R. 1980

N.R. 1984

N.R. 1978

T.H.E.S.I. 1976; N.R. 1979

H.A.B.S. 1971; N.R. 1975

N.R. 1979

N.R. 1975

R.T.H.L. 1964; N.R. 1975

R.T.H.L. 1962; N.R. 1970

R.T.H.L. 1974; N.R. 1978

H.A.B.S. 1936; R.T.H.L. 1969; N.R. 1980

N.R. 1979

N.R. 1984

N.R. 1980

N.R. 1971

R.T.H.L. 1974; N.R. 1974

N.R. 1980

N.R. 1984

N.R. 1978

R.T.H.L. 1962; N.R. 1978

R.T.H.L. 1967; N.R. 1979

N.R. 1977; R.T.H.L. 1981

N.R. 1979

N.R. 1981; R.T.H.L. 1982

R.T.H.L. 1962; N.R. 1979

R.T.H.L. 1968; N.R. 1973

N.R. 1983 
Table 5, continued

Site Name/Number

Farmers Union Gin Co.

Rylander-Kyle House

San Marcos Milling Co.

W1111ams-Tarbutton House

Hillsboro Cotton Mills

Joe E. Turner House

Wright-Henderson-Duncan House

Beaumont Commercial District

French Home Trading Post

Hinchee House

McFaddin House Complex

John Ruckman House

Walter C. Porter Farm

Warren and Myrta Bacon House

Earle-Napler-Kinnard House

East Terrace (John Wesley Mann House)

Col. Will1am A. Fort House

Rotan-Dossett House

Jefferson Historic District

Freeman Plantation House

Fort Duncan (41MV2)

Landmark Inn Complex (Vance Hotel)

Medina Dam

San Xavier Mission Complex (41MM10, 41MM11, 41MM16 through 41MM18)

Kiomatia Mounds Archeological District (41RR7, 41RR14) (Wright Plantation)

$\begin{array}{ll}\text { Location } & \text { State/National } \\ \text { (County) } & \text { Designation(s) }\end{array}$

Hays R.T.H.L. 1981; N.R. 1983

Hays N.R. 1983

Hays N.R. 1983

Hays N.R. 1983

Hill N.R. 1984

Hill H.A.B.S. 1965; N.R. 1977

Hood R.T.H.L. 1978; N.R. 1978

Jefferson N.R. 1978

Jefferson R.T.H.L. 1970; N.R. 1970

Jefferson N.R. 1978; R.T.H.L. 1982

Jefferson $\quad$ R.T.H.L. 1976; N.R. 1971

Karnes

R.T.H.L. 1970; N.R. 1979

Kaufman

N.H.L. 1964; S.M. 1970

Lubbock

R.T.H.L. 1982; N.R. 1982

McLennan

R.T.H.L. 1969; N.R. 1971

McLennan

R.T.H.L. 1962; N.R. 1972

McLennan

N.R. 1970

McLennan

R.T.H.L. 1978; N.R. 1979

Marion

R.T.H.L. (various);

H.A.B.S. (various);

N.R. 1971

Marion

H.A.B.S. 1934, 1971;

R.T.H.L. 1967, 1980;

N.R. 1969

Maverick

C.M. 1936; R.T.H.L. (Lee Bldg.) 1968; S.M. 1970;

N.R. 1971; H.A.B.S. 1972

Medina

H.A.B.S. $1934 ;$ R.T.H.L。 1965; N.R. 1972

Medina

N.R. 1976; S.M. 1978

Milam

C.M. 1936; N.R. 1973

Red River 
Table 5, continued

$\begin{array}{lll}\text { Site Name/Number } & \text { Location } & \text { State/National } \\ \text { (County) } & \text { Designation(s) }\end{array}$

Calvert Historic District

Oliphant House

Capt. Thomas William Blount House

William Garrett Plantation Home

Mission Nuestra Señora de los Dolores de los Ais (Mission Hill) (41SA25)

Col. John Dewberry House

Barnard's Mill (Old Marks-English Hospital)

LaBorde Residence, Store, and Hotel

(Ringgold Hotel)

Hutcheson-Smith House

Marrow Bone Archeological Site (41TR62) (Grist Mill Component)

Neil P. Anderson Building

William Azro Benton House

Public Market Building

Aynesworth-Wright House

John Brizendine House

Thomas F. McKinney Homestead (41TV489)

Michael Paggi House

Charles Taylor Rather House

Stavely-Kunz-Johnson House

Mission Creek Dam and Acequia Site (41VT13)

Victoria Grist Windmill

Liendo Plantation

Capt. Basil M. Hatfield Plantation

William Wescott Browning House

Stage Coach Inn

\begin{tabular}{|c|c|}
\hline Robertson & S.M. 1975; N.R. 1978 \\
\hline Sabine & N.R. 1977 \\
\hline San Augustine & R.T.H.L. $1962 ;$ N.R. 1973 \\
\hline San Augustine & $\begin{array}{l}\text { H.A.B.S. } 1934 ; \text { R.T.H.L. } \\
\text { 1962; N.R. } 1977\end{array}$ \\
\hline San Augustine & C.M. 1936; N.R. 1977 \\
\hline Smith & $\begin{array}{l}\text { H.A.B.S. 1936; R.T.H.L. } \\
\text { 1962; N.R. } 1971\end{array}$ \\
\hline Somerville & R.T.H.L. 1962; N.R. 1982 \\
\hline Starr & N.R. 1980 \\
\hline Tarrant & R.T.H.L. 1982; N.R. 1984 \\
\hline Tarrant & S.M. 1977, 1979; N.R. 1978 \\
\hline Tarrant & R.T.H.L. 1978; N.R. 1978 \\
\hline Tarrant & R.T.H.L. 1971; N.R. 1978 \\
\hline Tarrant & N.R. 1984 \\
\hline Travis & N.R. 1979; R.T.H.L. 1980 \\
\hline Travis & R.T.H.L. 1974; N.R. 1974 \\
\hline Travis & N.R. 1974 \\
\hline Travis & N.R. 1975; R.T.H.L. 1980 \\
\hline Travis & N.R. 1979 \\
\hline Travis & N.R. 1980 \\
\hline Victoria & N.R. 1980 \\
\hline Victoria & $\begin{array}{l}\text { R.T.H.L. 1962; T.H.E.S.I., } \\
\text { N.R. } 1976\end{array}$ \\
\hline Waller & $\begin{array}{l}\text { H.A.B.S. 1934, 1936; C.M. } \\
\text { 1936; R.T.H.L. 1964; } \\
\text { N.R. 1971 }\end{array}$ \\
\hline Washington & R.T.H.L. 1965; N.R. 1971 \\
\hline Washington & H.A.B.S. 1936; N.R. 1972 \\
\hline Washington & $\begin{array}{l}\text { H.A.B.S. 1936; R.T.H.L. } \\
\text { 1969; N.R. } 1976\end{array}$ \\
\hline
\end{tabular}

Robertson

Sabine

Augustine

H.A.B.S. 1934; R.T.H.L。

1962; N.R. 1971

R.T.H.L. 1962; N.R. 1982

Starr

1969; N.R. 1976 
Table 5, continued

$\begin{array}{lll}\text { Site Name/Number } & \text { Location } & \text { State/National } \\ \text { (County) } & \text { Designation(s) }\end{array}$

Tunstal1-Langhorne House (Waverly)

Asa Hoxey Home

John M. Brown House

San José de Palafox Historic/Archeological District (41WB39, 41WB46, 41WB48, 41WB50 through 41WB52)

Frank Kel1 House

Rallroad Produce Depot

Bryson Stage Coach Stop

Capt. Nelson Merrell House

David H. McFadin House

LIVESTOCK

Fulton Mansion (41AS79)

T. H. Mathis House

JA Ranch (Goodnight Ranch)

Maj. Archibald Johnson Rose House

King William Historic District

Mission Parkway Historic/Archeological

District (41BX3 through 41BX5, $41 \mathrm{BX} 12$, 41BX237 through 41BX260, $41 \mathrm{BX} 265$ through $41 \mathrm{BX} 270,41 \mathrm{BX} 278$ through 41BX281)

Walker Ranch Archeological District (41BX180, 41BX184, 41BX187, 41BX189 through 41BX192, 41BX197 through $41 \mathrm{BX} 199,41 \mathrm{BX} 201,41 \mathrm{BX} 210,41 \mathrm{BX} 217$, $41 \mathrm{BX} 222,41 \mathrm{BX} 223,41 \mathrm{BX} 228)$

Maverick-Altgelt Ranch and FenstermakerFromme Farm Historic/Archeological District (41BX493 through 41BX499)

Durazno Plantation

$\begin{array}{ll}\text { Washington } & \text { R.T.H.L. 1967; N.R. } 1983 \\ \text { Washington } & \text { R.T.H.L. 1962; N.R. } 1976 \\ \text { Washington } & \text { N.R. } 1975 \\ \text { Webb } & \text { R.T.H.L. 1972; N.R. } 1973\end{array}$

Wichita

N.R. 1978 ; R.T.H.L. 1981

Williamson

N.R. 1975

Williamson

N.R. 1978; R.T.H.L. 1981

Williamson

H.A.B.S. 1965; N.R. 1970

Williamson

H.A.B.S. 1936, 1937;

R.T.H.L. 1965; N.R. 1980

Aransas

H.A.B.S. 1936, 1937; C.M. 1936; R.T.H.L. 1970; N.R. 1975

Aransas

H.A.B.S. 1936; N.R. 1971

Armstrong

Bell

N.H.L.

Bexar

N.R. 1978; R.T.H.L. 1979

R.T.H.L. (various); N.R. 1972

Bexar

N.R. 1975

Bexar

N.R. 1975

Bexar

N.R. 1979

Brazoria

N.R. 1980 
Table 5, continued

$\begin{array}{lll}\text { Site Name/Number } & \begin{array}{l}\text { Location } \\ \text { (County) }\end{array} & \begin{array}{l}\text { State/National } \\ \text { Designation(s) }\end{array}\end{array}$

Homer Vilson Ranch

Mayfield Dugout

Mark A. Withers Residence

(Mark Withers Museum)

Orcoquisac Archeological District (41CH22, $41 \mathrm{CH} 53,41 \mathrm{CH} 54,41 \mathrm{CH} 175,41 \mathrm{CH} 180$, 41CH181)

Ammie Wilson House

Cloud-Stark House

Guadalupe Ranch/41CU95

Post West Dugout/41GR189

LBJ National Historic Park

Captain Barton Peck House

Mission Espíritu Santo (Nuestra Señora del Espíritu Santo de Zuñiga) (41GD1)

R. B. S. Foster House

James L. Autry House

Ragsdale-Jackman-Yarbrough House

La Lomita Historic District

Rancho Toluca

Joe E. Turner House

Wright-Henderson-Duncan House

John W. Knox House

Grierson-Sproul House

McFaddin House Complex

Meredith Hart House

Matthew Cartwright House

Camp Verde (41KR111)

Charles Armand Schreiner House
Brewster

Briscoe

Caldwell

Chambers

Collin

Cooke

Culberson

Garza

Gillespie

Goliad

Grimes

Harris

Hays

Hidalgo

Hidalgo

Hill

Hood

Jack

Jeff Davis

Jefferson

Johnson

Kaufman

Kerr

Kerr
N.R. 1971

H.A.B.S. 1964; N.R. 1975

N.R. 1973

N.R. 1976

R.T.H.L. 1978; N.R. 1978

N.R. 1982

N.R. 1978

N.R. 1978

N.H.S.

H.A.B.S. 1936, 1937;

R.T.H.L. 1962; N.R. 1979

C.M. 1936; R.T.H.L. 1969;

N.R. 1977

H.A.B.S. 1936; R.T.H.L. 1969; N.R. 1980

N.R. 1980

R.T.H.L. 1972； N.R. 1983

R.T.H.L. (Chapel) 1964, (farms) 1981; N.R. 1975

S.M. 1982; N.R. 1983

H.A.B.S. 1965; N.R. 1977

R.T.H.L. 1978; N.R. 1978

R.T.H.L. 1974; N.R. 1979

N.R. 1982

N.R. 1971; R.T.H.L. 1976

R.T.H.L. 1965; N.R. 1977

C.M. 1936; N.R. 1979

C.M. 1936; R.T.H.L. 1962;

N.R. 1973

S.M. 1970; N.R. 1975 
Table 5, continued

\begin{tabular}{|c|c|c|}
\hline Site Name/Number & $\begin{array}{l}\text { Location } \\
\text { (County) }\end{array}$ & $\begin{array}{l}\text { State/National } \\
\text { Designation(s) }\end{array}$ \\
\hline Tulahteka (Louis Albert Schreiner Mansion) & Kerr & N.R. 1982 \\
\hline King Ranch & Kleberg & $\begin{array}{l}\text { N.H.L. 1961; S.M. 1965, } \\
\text { 1977; R.T.H.L. (Ranch HQ) } \\
1981\end{array}$ \\
\hline Warren and Myrta Bacon House & Lubbock & R.T.H.L. 1982; N.R. 1982 \\
\hline Brown-Dorsey House & Midland & R.T.H.L. 1962; N.R. 1982 \\
\hline Scott-Majors House (Heritage House) & Mitchell & R.T.H.L. 1966; N.R. 1979 \\
\hline Britton-Evans House (Centennial House) & Nueces & R.T.H.L. 1966; N.R. 1976 \\
\hline Charlotte Scott Sidbury House & Nueces & R.T.H.L. 1976; N.R. 1983 \\
\hline $\begin{array}{l}\text { Canon Ranch Archeological District } \\
\text { (Ranching Component) }\end{array}$ & Pecos & N.R. 1982 \\
\hline Mary Elizabeth Bivins House & Potter & R.T.H.L. 1965; N.R. 1974 \\
\hline Landergin-Harrington House & Potter & N.R. 1977 \\
\hline Shelton-Houghton House & Potter & N.R. 1980; R.T.H.L. 1981 \\
\hline McBride Ranch House & Potter & R.T.H.L. 1971; N.R. 1975 \\
\hline Fortín de la Ciénega (41PS37) & Presidio & N.R. 1976 \\
\hline L. T. Lester House & Randall & R.T.H.L. 1967; N.R. 1978 \\
\hline John Howland Wood House & Refugio & N.R. 1983 \\
\hline $\begin{array}{l}\text { Capt. Thomas William Blount House } \\
\text { LaBorde Residence, Store, and Hotel } \\
\text { (Ringgold Hotel) }\end{array}$ & $\begin{array}{l}\text { San Augustine } \\
\text { Starr }\end{array}$ & $\begin{array}{l}\text { R.T.H.L. 1962; N.R. } 1973 \\
\text { N.R. } 1980\end{array}$ \\
\hline Blackstone Hotel & Tarrant & N.R. 1984 \\
\hline Burk Burnett Building & Tarrant & N.R. 1980 \\
\hline Fort Worth Stock Yards Historic District & Tarrant & $\begin{array}{l}\text { R.T.H.L. (Exchange Bldg.) } \\
\text { 1967; N.R. } 1976\end{array}$ \\
\hline W. T. Waggoner Building & Tarrant & N.R. 1979 \\
\hline Wharton-Scott House (Thistle Hill) & Tarrant & $\begin{array}{l}\text { H.A.B.S., N.R. 1975; } \\
\text { R.T.H.L. } 1977\end{array}$ \\
\hline Laguna Gloria & Travis & R.T.H.L. 1975; N.R. 1975 \\
\hline George Washington Littlefield House & Travis & R.T.H.L. 1962; N.R. 1970 \\
\hline Charles Taylor Rather House & Travis & N.R. 1979 \\
\hline New Mexico Pastor Archeological Sites in & various & N.R. 1984 \\
\hline
\end{tabular}


Table 5, continued

\begin{tabular}{|c|c|c|}
\hline Site Name/Number & $\begin{array}{l}\text { Location } \\
\text { (County) }\end{array}$ & $\begin{array}{l}\text { State/National } \\
\text { Designation(s) }\end{array}$ \\
\hline Los Ojuelos Ranch Historic District & Webb & N.R. 1976 \\
\hline William Benjamin Hamilton House & Wichita & N.R. 1983 \\
\hline Doan's Adobe House & Wilbarger & $\begin{array}{l}\text { C.M. 1936; R.T.H.L. 1962; } \\
\text { N.R. } 1979\end{array}$ \\
\hline David H. McFadin House & Williamson & $\begin{array}{l}\text { H.A.B.S. 1936, 1937; } \\
\text { R.T.H.L. 1965; N.R. } 1980\end{array}$ \\
\hline Rancho de las Cabras (41WN30) & Wilson & N.R. 1973 \\
\hline Joseph Henry Polley Mansion (Whitehall) & Wilson & $\begin{array}{l}\text { H.A.B.S. } 1936 \text {; R.T.H.L. } \\
\text { 1962; N.R. } 1980\end{array}$ \\
\hline Daniel Waggoner Mansion (El Castile) & Wise & R.T.H.L. 1962; N.R. 1974 \\
\hline Dolores Nuevo (41ZP78) & Zapata & R.T.H.L. 1972; N.R. 1973 \\
\hline Corralitos Ranch (41ZP74) & Zapata & N.R. 1977 \\
\hline San Francisco Ranch (41ZP76) & Zapata & N.R. 1977 \\
\hline AQUATIC FARMING & . & \\
\hline Galveston Maritime Site & Galveston & N.R. 1975 \\
\hline
\end{tabular}

Spanish influence on agriculture in Texas had declined by 1800 , and Mexico retreated from the region in the 1840 s creating a vacuum which was filled with increasing rapidity by Anglo-American agriculturalists. Liberal Spanish and Mexican land policies, especially, had encouraged the growing of crops such as cotton, corn, and cane, and the raising of livestock (Carlson 1982:19) so that by the 1840s, Texas was characterized as "an overwhelmingly agricultural society." According to Lowe and Campbell (1987:9), three-quarters of Texas' antebellum free population "was directly engaged in farming of some type, whether it was small-scale, self-sufficient food production on the northern plains, stock raising in southern Texas, or cotton culture in the eastern uplands." of the remaining population, most individuals were involved in agriculture indirectly, either as suppliers of agriculturally related goods and services or as consumers.

Prior to the Civil War, most Texas farmers and ranchers lived east of the 98th meridian. In the East Texas pine and hardwood uplands, migrants from southern states raised corn, cotton, and garden vegetables. On the coastal prairies along the Trinity, Brazos, and Colorado rivers, farmers established the State's premier cotton and sugar plantations. In Calhoun and Victoria counties, cattle raising predominated, while sheep and goat raising and grain and cotton production typified the German communities located in the Hill Country. The north-central part of the State could have produced large quantities of cotton and wheat, but commerical agriculture remained relatively unimportant in the area due to a lack of adequate transportation facilities (Lowe and Campbel1 1987:10-13). 
Of all the crops grown in antebellum Texas, cotton was by far the most important. Sugar comprised a great but secondary commercial crop, while corn was the most important grain product. Wheat production grew steadily, and garden vegetable growing was ubiquitous (Lowe and Campbel1 1987:19-23).

Livestock raising remained secondary to cotton in the State's economy prior to the Civil War. However, it was an important part of the agricultural picture. In most areas, cattle and hogs were raised for home consumption on an open, unfenced range where breeding was unsupervised. Animals were collected and penned once a year for branding and slaughtering, and cattle raisers on the coastal plains sometimes collected their animals for drives to markets in New Orleans. In northeastern Texas, where farmers raised grain and food crops and herded livestock, cattle were driven to markets in Shreveport, Louisiana, and Jefferson, Texas, their ultimate destination being the New Orleans slaughterhouses, packing plants, and tanneries. Piney woods cattle also were driven to Louisiana markets, but some were taken as far east as Mississippi (Lowe and Campbell 1987:24-26).

By the 1860s, Texas was not only overwhelmingly agricultural in its economic base, but the population participating in that economy lived, for the most part, east of the Cross Timbers. In the $1870 s$, however, the slaughter of natural species such as buffalo and the expulsion of Native American tribes opened the western two-thirds of the State to agricultural development. Stockraisers, whether sheepmen or cattlemen, flooded the area by the early 1880s, aided in their exploitation of native grasses by the construction of major rall lines and of towns which brought markets to the range. By 1884, the State had experienced a major agricultural boom which continued well into the twentieth century despite the collapse of livestock markets. On the Rolling and South plains and in the Texas Panhandle, farms developed on land that previously had been thought suitable only for livestock production. The development of technologies such as barbed wire and windmills effectively ended the open-range livestock industry and encouraged the growing of economically important crops such as cotton and wheat. As a result, crop production achieved parity with and, in many parts of Texas, surpassed livestock production by 1930.

Sheep and Cattle Ranching in Texas:

A Summary of Scope and Trends

Much has been made of the competition that existed among producers of various agricultural products. Indeed, the antagonism that developed between raisers of sheep and raisers of cattle as they competed for a steadily decreasing open range has become legendary. Unfortunately, the emphasis placed on the competition between the two groups has tended to deflect attention from the numerous important ways in which sheep and cattle raisers shared a common history. Established by the Spanish, the industries were equally hampered by Indian depredations until the mid 1870s, shared the benefits of the introduction of Improved breeding stock after the $1840 \mathrm{~s}$, moved together into the area west of the 98 th meridian during the 1870s, experienced the impact of foreign investment in the 1880s, and had to adapt to changes imposed by legislation which favored homesteaders and eventually resulted in the end of open-range ranching. 
Sheep Raising

CHRONOLOGY

The introduction of sheep to present-day Texas occurred in 1681-1682 near Paso del Norte when the Spanish established missions at San Lorenzo and Ysleta. This initial foray was followed by the importation of sheep to East Texas by Alonso de León and Domingo de Terán in 1690 and to the location of present-day San Antonio by Terán in 1716. By 1727, San Antonio de Valera inventoried 543 sheep and goats, while other significant herds existed at Presidio Nuestra Señora de Loreto (La Bahía) and Mission Espíritu Santo de Zuñiga on the Guadalupe River (Wentworth 1939:7; Towne and Wentworth 1945:117).

The spread of sheep followed the opening of missions such as San Xavier on the San Gabriel River in central Texas in 1745, and of presidios such as San Luis de las Amarillas on the San Saba River in west-central Texas in 1757. The same year, a colony of 50 Spanish families settled on the lower Trinity River, bringing with them more than 9,000 sheep. Simultaneously, a multitude of Spanish ranches appeared in the Rio Grande Valley, and by the 1760s, thousands of sheep, goats, and cattle grazed in South Texas. The populations around the San Antonio missions continued to grow with the result that the mission flocks totaled 12,000 sheep and goats by 1762. Sheep also were raised on the Texas-Louisiana border but remained secondary in numbers and importance to cattle, horses, and hogs (Wentworth 1939:35, 37, 39; Towne and Wentworth 1945:121; Havins 1952:4).

By the last third of the eighteenth century, Spanish Texas had a population of some 40,000 to 50,000 sheep. But soon after, the industry entered a period of decline caused by Indian raids that destroyed herds and resulted in the abandonment of Spanish ranches, by the secularization of the missions, and by droughts and severe winters such as those in the 1780s. Unquestionably, Spain made lasting contributions to the range sheep and goat industries by demonstrating that the animals could thrive in Texas, initiating practices such as twice-a-year breeding, and introducing specific breeds, methods, terminology, and organization. But the attention that the Spanish had to give to political developments of the early nineteenth century left the field of livestock management open to the Anglos, English, and Germans who dominated the industry after the 1820s (Towne and Wentworth 1945: 122; Carlson 1982:17).

Anglo-American involvement in the sheep-raising industry began slowly, in part because herds were located primarily along the humid coast, a region ill-suited to sheep raising. On the positive side, however, Austin colonists brought with them sheep from Vermont, and the crossbred product of New England Merinos and Spanish churros had what one historian called a "magical effect." Two-pound fleeces were replaced by fleeces weighing 6 to 8 pounds, and carcass weight also increased dramatically (Wentworth 1939:23; Towne and Wentworth 1945:123).

The initial improvement of breeds that occurred in Texas in the 1830s was followed by more-intensive breeding experiments in the 1840s. The Germans, in particular, made noteworthy contributions in this area. Ottoman von Behr of Sisterdale, Kendall County, bred imported German Merino (Saxon) rams with a flock of churros to create a flock of highquality sheep by 1854. Other, similar efforts were made by H. J. Richarz near San Antonio and later D'Hanis (Medina County) between 1849 and 1854. In Comal County, German families 
introduced by Prince Solms crossbred German and Mexican sheep and then constructed a mill to produce clothing and blankets (Towne and Wentworth 1945:123; Carlson 1982:24-25).

By 1850 Texas was poised for participation in what historians have called the first "sheep boom," a phenomenon that was touched off by several different factors. First, changes in national preferences for clothing fashions caused Americans to choose wool over cotton. Second, techniques of wool manufacturing--carding, spinning, weaving, and fulling (thickening and compacting of wool)--all improved. Third, Texas land was cheaper than that In the northeastern United States and the climate required less feeding, two factors that attracted the attention of out-of-state sheep raisers and investors. Finally, and perhaps most importantly, sheep became the subject of a "boosting" campaign that touted the profits to be made from participation in sheep ranching and resulted in a large influx of both sheep raisers and herds from Illinois, Missouri, Indiana, Arkansas, New England, and California (Wentworth 1939:34, 1943:27; Towne and Wentworth 1945:123, 125-126; Havins 1952:4-5, 7-10; Carlson 1982:66-67).

Unquestionably, the individual most responsible for the pre-Civil War sheep boom in Texas was George Wilkins Kendall, participant in the Texan-Santa Fe Expedition of 1841, editor of the New Orleans Picayune, and inveterate promoter of his adopted state. Kendall not only wrote innumerable newspaper articles which were circulated nationally and touted the beneficial economics of sheep raising in Texas, he also participated in the industry, running a ranch near Boerne, Texas. For 17 years, he demonstrated the suitability of the area to livestock raising while working to improve sheep breeds, defying a Federal blockade of New Orleans, and inventing modern methods of dipping that are used to the present day. By 1867, when Kendall died, his promotion of the range sheep and goat business had enabled It to survive the vicissitudes of the Civil War, had shifted the emphasis from mutton to wool production, and had left the industry poised for two decades of unprecedented growth (Towne and Wentworth 1945:127-129; Carlson 1982:36-37, 44-47). In fact, between 1869 and 1890, the number of sheep in Texas increased from 1,223,000 head to 4,752,640 head, and the State rose in national ranking from eleventh place to first place (Havins 1952:11).

A number of factors were responsible for the State's second and most vigorous sheep boom. With the disappearance of buffalo herds and hostile Indians, new pastures throughout South and West Texas, the Edwards Plateau, the Southern and Rolling plains, and the Panhandle areas opened up. Thousands of head of sheep were driven to the "free grass" ranges, and the boom reached phenomenal proportions in the Rio Grande Plain and Edwards Plateau. Heartened by heightened prices for wool, eager young men poured into Texas from California and the northern states, as well as from Europe, while experienced sheepmen from New Mexico followed watercourses such as the Canadian to establish plazas and sheep camps in the Panhandle. The westward progress of railroads such as the Texas Pacific and Southern Pacific facilitated shipping, while the development of towns made markets and businesses associated with the industry conveniently available (Texas Wool 1882:4; Ashburn 1934:157; Towne and Wentworth 1945:133; Holt 1956:18, 19; Taylor 1980; Carlson 1982:48, 54, $62,68,74-75,86,102-103,120,152,157)$.

Like all such phenomena, the sheep boom of the 1880 s had to end. The enormous herds that had typified the industry had overtaxed the range with the result that the fertile grasslands of South Texas were turned into veritable wastelands of scrub brush. Bad weather in the form of severe droughts in the early 1880 s and in 1892 and 1893, and the notoriously harsh winter of 1886, resulted in catastrophic die-offs. A nationwide economic panic in 1893, which some historians believe was the worst of the nineteenth century, 
lowered wool prices and ruined once-profitable markets (Carlson 1982:64, 166). Finally, the introduction of barbed wire and disappearance of free ranges changed the business of stock raising forever.

In response to changing markets, weather, and range conditions, the sheep raising industry underwent a number of changes after 1900. In the eastern part of Texas, the open range and Spanish management systems disappeared, replaced by small flocks raised by farmers to supplement other agricultural activities (Carlson 1982:84). Ranchers for whom sheep remained the primary livestock animal retrenched with the result that the Edwards Plateau became the area of greatest concentration of flocks in the State. Wool growers established commission sales warehouses and organized associations to protect and promote the industry. Increased attention was paid to stock breeding in the 1930s, and the decline in wool markets which typified the 1950s gave way to a renewed interest in natural fibers beneficial to the industry at large. Today, the Edwards Plateau remains the focus of sheep raising in Texas, and its economy is dominated by that industry (Carlson 1982:101, 188, 205-207, 212-213).

ORGANIZATION

Because sheep ranching occurred over such a wide geographical area and over a long period of time, and because it involved so many individuals of different cultural backgrounds, practices associated with the industry varied greatly. The organization of a large South Texas sheep ranch, for example, was different from the partido system practiced in parts of West Texas. As a result, it is not possible to describe fully all the variables involved with the organization of the sheep ranching industry. It is possible, however, to mention several of the more commonly described organizational types which have been recorded by historians of the Texas sheep industry.

Perhaps the most hierarchical system was that found in South Texas on the Rio Grande Plain where ranches handling 20,000 to 50,000 head of sheep used a Spanish system. At the top was the owner who may or may not have been absentee, but who usually hired a ranch foreman or superintendent to act in his stead. Below the foreman was the mayordomo who was always on the range traveling from camp to camp and often was the final word on anything pertaining to the sheep or to the range. Below the mayordomo were three caporales who rode the range, supplied the camps, provided monthly reports, oversaw as many as 18,000 sheep each, and directed the work of three vaqueros. Each vaquero, in turn, supervised three pastores. The pastor, in turn, was responsible for 1,000 to 3,000 head of sheep that he stayed with at all times (Carlson 1982:56-57).

Two different systems have been described in West Texas. According to Maudslay (1951: $36)$, an outfit might consist of 15,000 to 20,000 sheep with 10 herders, 3 or 4 wagon drivers and cooks, 1 or 2 rustlers (the equivalent to the South Texas vaquero) (Carlson 1982:57), and a general manager who usually was the owner. Other hands who were called in for special jobs during shearing season might include a capitan who ran a crew of 25 to 40 men, a boy who applied worm medicine, a lanero who gathered fleeces, packers who put the wool in bags, and occasionally, a sub-boss (Maudslay 1951:118). In other parts of West Texas, owners and herders used the partido system in which bankers or merchants purchased sheep and then farmed them out on shares to individual herders. The herder oversaw the flock on leased land and was required to return to the owner a portion of the increase of the herd as well as a share of the annual wool clip. Each man benefited from the 
arrangement with the owner showing an increase in the numbers of sheep and a profit from the wool, and the herder acquiring a few head and his share of the clip (Carlson 1985:8-9).

In northwestern Texas, pastores from New Mexico established migratory sheep circuits along the Canadian and Red river valleys, trailing herds slowly through the PanhandlePlains area where they lambed and then circling back home and arriving in time for shearing (Taylor 1980:20-21). A similar activity was practiced on the Southern Plains by men called drifters, herders who neither owned nor leased land but who moved slowly in search of good grass and water (Carlson 1982:165).

Organization of the sheep industry reached far beyond individual flocks and ranches to embrace a system of markets, warehouses, and banks. These institutions changed, in turn, as various parts of the State opened up to the industry. Among the earliest markets was Corpus Christi, which was the collection point for ranchers in the Rio Grande Plain (Carlson 1982:60). As the industry grew north of the Nueces River and westward onto the Edwards Plateau, San Antonio eventually eclipsed Corpus Christi. Railroad construction and the opening of the Trans-Pecos West and Southern Plains, in turn, spawned a new set of market centers, the most prosperous, of which were Brownwood, Abilene, Colorado City, Ballinger, Kerrville, San Angelo, Eldorado, and Sonora (Ashburn 1934:157; Wentworth 1943: 29-30; Holt 1956:20; Carlson 1982:112, 165). Ranchers in the Panhandle area more typically used the Dodge City, Kansas, market.

Just as market centers developed in response to the growth in sheep ranges and numbers, so also warehouses, mercantile establishments, and banks developed to handle the increase in wool. One of the earliest and largest warehouses was located in San Antonio where T. C. Frost, the city's principal wool merchant, built structures to house the clip and acted as a commission salesman. Other pioneer warehouses were operated by Theodore Heick, who opened a warehouse in Abilene on the Texas and Pacific line (1882), and Charles Schreiner of Kerrville, who erected a facility adjacent to the San Antonio and Aransas Pass Railroad track (ca. 1887). San Angelo became the location of the State's first modern wool warehouse in 1909, when Robert Massie, C. C. Walsh, and Judge J. A. Whitten organized the Wool Growers Central Storage Company. The facility offered ranchers complete facilities for handling wool from the range to the final market (Ashburn 1934:157; Wentworth 1943:2930; Carlson 1982:77, 103, 112-113).

A natural outgrowth of the warehouse system was the establishment of stores and banks. T. C. Frost, for example, ran a store on Main Plaza in San Antonio where ranchers purchased supplies by drawing against accounts resulting from sales of wool to Frost. They left the balance of their money with him as well, using the facility in a corner of his store marked "bank." Such deposits formed the nucleus of the present-day Frost National Bank of San Antonio, an institution that became Frost's primary business after 1892 (Wentworth 1943:29; Carlson 1982:77).

\section{ACTIVITIES AND MATERIAL CULTURE}

Actlvities and material culture associated with sheep raising in Texas were as varied as the methods of organizing and running a ranch or other sheep-raising operation. However, because the anlmals and products shared similarities throughout the history of ranching, certain activities were common to most sheep ranges. 
The most basic activity was called trailing and, sometimes, drifting. Using methods developed in the Near East and refined in Europe, drovers trailed sheep everywhere in a minimally organized fashion that could be adapted to specific topographies and environments. Typically, men on foot drove herds of sheep numbering from 1,500 to 25,000 head. The herd moved slowly, spreading out farther on the open range than cattle did. Movement generally was continuous, except when the animals bedded down. According to Carlson (1982: 134), "Wherever they might be heading, sheep with rare exceptions fattened and throve as they moved, for grazing from range to range was a natural inclination for them--the pattern of their life."

Some modification of the usual trailing methods was required during the lambing season when the herd was thrown together and moved to a preselected location. Movement was slow, with ewes and the newly dropped lambs allowed to lag behind until evening when they were gathered together in an area that was separate from the dropping herd. The following day, the main herd was slowly moved on with ewes and their lambs dropped during the night also allowed to remain behind. With the formation of a herd of approximately 500 ewes and their lambs, a stationary group was held in camp, and their herder identified all twins (Maudslay 1951:113-115).

Identification of sheep took one or more forms. Often, new lambs were earmarked by notching one or both ears in specific ways that were registered at the county courthouse. Marking also was accomplished by painting a distinctive symbol on a freshly shorn sheep. Some animals were branded on the jaw, cheek, or across the nose (Maudslay 1951:115; Carlson $1982: 59-60)$.

When male sheep had reached an appropriate age they were castrated, assuring the production of better mutton and improving the genetics of the herd by controlling breeding. Most animals also were docked for sanitary reasons. In this procedure, all but approximately two inches of the tail were removed using heavy knives, hatchets, chisels, or redhot docking irons (Carlson 1982:59).

Shearing season was probably the busiest time of the year for ranchers and their employees. Two clips were common in the Rio Grande Valley--April to June and August to September--but one clip was a more usual practice elsewhere in Texas. Regardless of where it occurred, most shearing was done by itinerant bands of men who were organized by captains in Mexico and moved from ranch to ranch. The job was "sweaty, cumbersome work," done by hand in large barns or brush-covered pens. Shearers assembled in the pens at daybreak, and each man tied the feet of approximately 10 sheep at a time. After the fleeces were cut, a lanero gathered each one and carried it in an apron to the packers who sewed them into bags. "Checks" made of tin cut from cans were then distributed to the shearers as they finished their sheep (Hayes 1878:69-70; Maudslay 1951:118; Carlson 1982:58, 76).

With the conclusion of shearing, the wool was loaded onto horse-drawn wagons owned by teamsters. These men would sometimes hitch two or more heavily laden wagons together before freighting the wool to the closest warehouse (Carlson 1982:76).

Specific buildings and structures were used to facilitate the acquisition of the wool product, the most substantial being the ranch headquarters from which the operations of the ranch were directed; the barns, floors, or platforms on which the shearing was conducted; barns which were used to protect the animals; dipping pens; and warehouses to which the 
wool was transported. Many other sites that were associated with the trailing and care of sheep were more ephemeral, perhaps because of the migratory nature of the business.

Herders who operated alone often traveled with a sheep wagon which contained a bed, table, benches, cooking and eating utensils, food, and grain for the horses. Those not fortunate enough to have a wagon might find themselves sheltered by a pile of brush or a rag tent. The more common practice seems to have been for two men to travel together. One man acted as a rustler and directed the herder to new pastures; shuttled between camp and range headquarters; set up the camp and cooked; made corrals of canvas, brush, or rock (if they were deemed necessary); and made sure that the camp was well provisioned. Equipment for which the rustler was responsible might include a wagon, horses, tent, buffalo robes, blankets, water bucket, tea kettle, coffee pot, frying pan, pots, plates, cups, utensils, and food (Hayes 1878:68; Fenley 1945:8; Towne and Wentworth 1945:276; Maudslay 1951:37-38, 136; Carlson 1985:9).

The second man, who acted as herder, trailed the sheep from range to range as they were selected by the rustler. His equipment was minimal and was described by Maudslay (1951:36) as consisting of only a few,items. One item, a sling made of ibones from a dead cow, was used to throw rocks along the ground in front of a sheep herd in order to check the animals if they were traveling too fast. The sling also could be used to scare off cattle or to ward off wolves and other predators. A second useful item was a curved stick about 30 inches long with rounded ends that could be thrown along the ground and used for the same purpose as the sling. Other objects that herders might carry included a covered canteen, a small canvas satchel, and a piece of equipment called a punk mecha. Consisting of a piece of punk or cotton string, a piece of steel, and a piece of flint, the punk mecha was used to set fires, light cigarettes, or fulfill any number of other functions for which a flame was required (Maudslay 1951:36-37, 47-48).

Cattle Raising

\section{CHRONOLOGY}

Cattle were introduced to Texas by the Spanish in 1690 when Captain Alonso de León included cattle, oxen, and horses on his expedition to establish the first Spanish mission, San Francisco de los Tejas. Within two decades and despite Indian depredations, cattle had. increased and substantial herds grazed pastures located between the Neches and Trinity rivers (Myres 1969:11).

Augmentation of the early herds occurred in 1718 when Don Martín de Alarcón brought cattle and other livestock to the new presidio at present-day San Antonio, and by 1721, the Marquéz de San Miguel y Aguayo found wild "Castilian cattle" roaming as far west as the Guadalupe River (Myres 1969:11). These feral cattle and others associated with mission herds reproduced at an enormous rate so that, despite Apache and Comanche depredations along the San Antonio River and the abandonment of numerous Spanish ranches, some 70,000 head roamed in the vicinity of Missions Espíritu Santo and Rosario at Goliad in 1770 (Myres 1969:18-19; Wilson 1983:1-3).

By 1800 the foundations of the cattle industry in Texas had been laid, and Spanish ranches benefited both from the abundance of feral cattle and the liberal land policies 
that provided for grants of stock ranch sitios, each of which contained in excess of 4,000 acres. The positive aspects of an abundance of animals and beneficial land laws were not lost on Anglo-American and other colonists who brought with them their own tradition of cattle herding. By the 1830s, James Taylor White had established a large Trinity River spread on which his slaves herded some 30,000 head of cattle (Paul 1959:26; Jordan 1981:23; Carlson 1982:19; Wilson 1983:3).

With the defeat of Mexico in 1836, many Hispanic ranchers abandoned their holdings in South Texas and left herds that wandered over the strip of land between the Nueces and the Rio Grande. The Republic of Texas declared all unbranded cattle in the area to be public property, and Anglo cattlemen rushed to claim the animals and drive them to the interior of the Republic and east to the New Orleans market. Simultaneously, dairy cattle and improved beef stock were introduced by the colonists. Their interbreeding with the Spanish stock resulted in the Longhorn, a native type that many ranch historians considered to have been the bedrock of western cattle raising until the 1880s (Paul 1959: 26-27; Wilson 1983:4-6).

Longhorns multiplied as rapidly after the revolution of 1836 as their Spanish progenitors had during the eighteenth, century, and by 1845 a census indicated the presence of 134,000 head of cattle in Austin's Colony and the Atascosita District, 27,000 head in northeast Texas (part of Miller County, Arkansas), and numerous small herds in the Piney Woods of East Texas (Wilson 1983:6).

Jordan (1981:129-131, 134-139) has identified several principal sources of AngloAmerican ranching in Texas prior to the Civil War. The first of these was the Texas Coastal Prairie east of the Guadalupe and Lavaca rivers, an area where members of the Dobie, Cox, Kokernot, Littlefield, Wiseman, Welch, Barber, McFaddin, Polley, and other families lived and eventually fueled the spread of ranching up the Guadalupe, San Antonio, and Nueces river valleys by the 1850s. A second source of Anglo-American ranching stock, families, and cultural traditions was the Blackland Prairies of northeast Texas. Families such as the Bivins, Cartwrights, Chisums, Gunters, Lovings, and Waggoners ran cattle on the prairies and then moved west during the 1850s when they entered the Cross Timbers region. A third source of antebellum ranching was the Piney Woods where families such as the Dursts, Reynolds, Slaughters, Coggins, and others herded cattle before moving west to the Blackland Prairie and on to the Cross Timbers during the 1850s. Many of the families in the three source areas were heirs to different ranching traditions. What they shared, not only among themselves but also with their Hispanic counterparts, was skill in managing large herds from horseback, facility with a lasso, and efficiency in rounding up and branding cattle (Wilson 1983:6).

By 1860 the cattle and pioneer frontiers were the same, and Texas, with more than 3,533,000 head, had more cattle than any other state. The outbreak of the Civil War, however, had devastating effects on both the line of settlement and the cattle industry. With the withdrawal of federal troops and loss of manpower to the Confederacy, the frontier was left open to Indian depredations. A few hearty souls such as R. F. Tankersley who brought a herd to the South Concho, John Chisum who herded cattle on the main Concho, and Rich Coffey who ranched from a stockade in present-day Coleman County ventured to the fine pastures of west-central Texas in the 1860s. But for the most part, the area was left to the Indians and to Longhorns which continued to breed and increase.

At the end of the Civil War, Texas found itself with three to five million head of cattle on the open range and a number of individuals who realized the profits that might 
accrue if they could find a way to deliver the resource to northern markets. The mechanism developed to answer market demand was the cattle drive, a phenomenon that began in 1866 and continued during the open-range period of the 1880 s.

Ranching history's first drive was unsuccessful due to inexperience and unforeseen hazards on the trail. Successive drives met with success largely because of the efforts of Illinois native Joseph G. McCoy who understood the enormous profits that might result if he could join Texas herds with western railroads. He convinced the Kansas Pacific to ship cattle and developed a depot, holding pens, and shipping yards at Abilene, Kansas. Between 1867 and 1871, Abilene served as the terminus of the Chisholm Trail which funneled herds northward from the Nueces-Rio Grande river area, the Hill Country and Guadalupe River Valley, and pasturelands adjacent to the Blackland Prairie (Rickard 1927:31; Paul 1959:3032; Wilson 1983:12, 14-15).

Until 1873, the cattle industry grew. But in 1873, the failure of Jay Cooke's banking house precipitated a national panic. The number of cattle moving northward decreased from more than 400,000 head in 1873 to 151,000 in 1875. In response, cattlemen formed livestock organizations in an attempt to stabilize the industry and markets. As a result, retrenchment was rapid, and the cattle industry had fully recovered by 1879 (Paul 1959:34).

Contemporaneous with and contributory to the recovery of ranching was the rapid expansion of the ranching frontier after the mid 1870s. Following the decimation of buffalo herds and pacification of Indians throughout the Plains region, cattlemen pushed west from the Cross Timbers, Hill Country, and Rio Grande Plain, while ranchers from Kansas moved south into the Oklahoma and Texas panhandles. By the late 1870s; stock raising dominated the economies of all parts of Texas west of the 100th meridian. Cattlemen from the valleys of the Guadalupe, San Antonio, and Nueces rivers spread west into the Trans-Pecos, Big Bend, and Davis Mountains areas; Cross Timbers ranchers moved west into the Rolling Plains, out onto the West Texas plains (Jordan 1981:139-142), and finally onto the Caprock and into the Canadian River Valley areas; and Kansas ranchers, attracted by the lush pastures along the Beaver River and Coldwater and Palo Duro creeks, pushed herds southward.

The rush west and establishment of highly profitable ranches by individual cattlemen did not escape the notice of both American and European investors, the latter of whom had been exposed to Texas beef after the development of refrigeration made possible the shipment of "dead meat" (Rickard 1927:32). Investment in western cattle ranges was heavily promoted, and by the early 1880s, numerous cattle operations were owned by large domestic and foreign corporations. A period of unprecedented expansion resulted.

Not surprisingly, the boom of the early 1880s came to a sudden and cataclysmic end. Pastures everywhere were badly overstocked, and there was not enough grass to feed the enormous herds. A 23-month-long drought began in the summer of 1885, and the bitter winter of 1886-1887 contributed to losses which exceeded 50\% in many areas. A collapse in beef prices sent the market to less than one cent per pound in October 1887, and the onset of a national panic in 1893 ruined scores of individual stockmen and ranching corporations (Murrah 1981:60; Wilson 1983:43).

Ranching continued to dominate the economic picture in the western half of Texas until about 1895. But after that date, the agricultural balance shifted. Aided by changing land laws, construction of railroads, and the increasing availability of State, railroad, and ranch lands, farmers immigrated to the Plains in increasing numbers. Many cattle raisers 
themselves diversified, combining farming with ranching and practicing more-responsible range management. While numerous ranches still existed throughout the Rolling and Southern plains, the Panhandle, and West Texas, the balance between range and cultivated land had shifted permanently.

\section{ORGANIZATION}

Like sheep ranching, cattle ranching was a business whose practice varied considerably depending on when and where it occurred and on the cultural background of the rancher. Nevertheless, all successful ranching enterprises shared certain structures and participated in specific activities.

Individual, as opposed to corporate, ranching was widespread and had considerable longevity. It was typified by ranchers like C. C. Slaughter and his brothers, S. B. Burnett, George Washington Littlefield, and Thomas Bugbee who sought desirable pasture and water resources, established headquarters and numerous camps, marketed cattle, and adjusted more or less successfully to the vicissitudes of weather and economic conditions. Corporate ranching, typified by syndicates such as the XIT in the Panhandle, Texas Land and Cattle Company in the Valley, Coleman-Fulton Pasture Company on the coastal plain, or Espuela Land and Cattle Company on the Rolling Plains, had an organizational layer that was responsible to the shareholding owners of the ranch. This organizational layer consisted of a manager who was responsible for implementing board policy and "putting into practice tried and proven corporate precepts in a frontier setting" (Wilson 1983:39). Acting through a bookkeeper, the manager deposited money from sales, purchased goods and services, paid bills, and submitted regular reports to the board. On both privately and corporately owned ranches, work was done by hired hands who provided seasonal services and performed scores of jobs.

One of the jobs performed was that of trailing which sometimes was done by ranch employees. However, the greater number of drives were undertaken by firms and individuals who specialized in trailing. These companies contracted with ranches to deliver herds to specified destinations for a per-head price and were responsible for providing their own manpower, supplies, and equipment. According to one author, as many as $85 \%$ to $90 \%$ of the cattle that went up the trail were delivered to markets by private contractors (Wilson 1983:20).

The markets to which cattle were driven changed over time in response to factors including proximity to the range and diseases such as Texas fever which resulted in cattle quarantines or in the gradual westward shifting of trails. In Spanish times, for example, the principal market was Louisiana where the Opelousas and Beef trails ended. By 1845, Shreveport had become a major market with direct ties to New Orleans by way of the Red River (Jordan 1981:133; Wilson 1983:10).

A major market developed in California in the late 1840 s as a result of the Gold Rush, but the markets that had the greatest impact on the industry lay north of Texas. As early as the 1850s, some beef were driven to Kansas City and St. Louis; the Kansas and Chicago markets achieved florescence in the 1870s and 1880s (Jordan 1981:154; Wilson 1983:10). 
ACTIVITIES AND MATERIAL CULTURE

Numerous activities were essential to the successful running of a cattle outfit, and hands were expected to perform as many as a dozen or more different categories of jobs. According to Webb (1931:251), a typical ranch included a headquarters and an "outfit," the group of men who did the cow work and lived on the range from April to December. The "outfit" also referred to the physical accoutrements that the hands carried with them. These generally consisted of a chuck wagon which held food, bedding, and tents, as well as a "hoodlum wagon" which carried a water barrel, wood, and branding irons.

A wagon crew might consist of a boss who usually was the ranch foreman, a cook, hoodlum driver, horse wrangler, straw boss, and as many as 8 to 10 hands. In the winter, this number was reduced to more-or-less permanent employees who were located in different parts of the ranch at line camps (Webb 1931:252).

All hands were supplied with multiple horses kept together in a remuda overseen by a horse wrangler. The size of the remuda might be as many as 150 horses, and it either trailed with the wagon or was sent to, a round-up location without the wagon (Webb 1931: 252).

Cowboys furnished their own equipment which consisted of a saddle, bridle, saddle blanket, spurs, bedding (called a "hot roll"), 16- to 20-ounce tarp, and blankets. When at headquarters, the men stayed in a bunkhouse (Webb 1931:254-255).

Numerous daily tasks such as riding fence, maintaining windmills, and controlling predators were pursued throughout the year. Two special tasks, however, were done no more than once or twice a year. The first of these, the roundup, involved a series of subtasks such as tallying, cutting strays, spaying, castrating, marking, and branding. In the period of open-range ranching, prior to 1890 in most of Texas, roundups involved a cooperative effort among multiple ranches and began with the designation of roundup districts, selection of a roundup boss, and gathering of representatives from each ranch within the district at a predetermined location. Here, as many as 200 to 300 men might gather with 2,000 to 3,000 horses and numerous chuck wagons (Webb 1931:255-257; Wilson 1983:40).

At the beginning of each roundup, the boss selected assistants who were then assigned groups of hands. Each assistant and his hands scoured a specified range or section of the roundup district, bringing in "everything that wore hair and horns." After four to six days, a range usually was covered and the cattle were driven in such a way that they converged on the roundup camp. At that point, designated hands separated the cattle into herds based on ownership. The owner of the range first cleared then held his cattle out while the other herds were driven to the next range and their numbers augmented. From the first day unt1l the roundup was complete, there were as many separate herds as there were owners; the work involved in separating and holding the animals was both strenuous and tedious (Webb 1931:256-258).

A number of tasks were accomplished during roundups, the primary ones being branding and marking. Both designations of ownership were recorded in the appropriate county courthouse; they were essential elements in establishing legal ownership of adult cattle and their offspring. 
A second special task, cattle driving, was an activity that often followed spring roundup when certain cattle were cut out of the herd and turned over to a trail boss by the owner. Cowboys were selected to assist on the drive, and a cook was hired to man the chuck wagon, a mobile kitchen that carried tools, bedrolls, and a water barrel, and had a foldout counter, drawers and shelves, a canvas top, and a storage compartment or "boot" on the underside. Trailing was an arduous task involving responsibility for thousands of head of cattle. While each drive was different from all others, the successful ones resulted from "the deft application of time-tested procedures to natural circumstances--weather, terrain, and self-willed animals--that defied regimentation" (Webb 1931:259-268; Wilson 1983:20-22).

Much of cattle raising, like sheep raising, was a mobile occupation in which owners and hands were required to be on the move frequently, stopping only to camp briefly. Other activities resulted in the establishment and construction of permanent or semipermanent structures. The most substantial of these structures generally were located at the ranch headquarters and included components ranging from a dugout or half dugout to a main residence, outbuildings, and corrals. In many parts of Texas from the Cross Timbers west, ranch owners used a variety of building materials including sod, adobes, logs, pickets, stones, and lumber. House forms ranged from the simplest one-room dugout to large residences which occasionally equaled urban structures in complexity, sophistication, and richness of detail.

of all the building types, the dugout was the most common. A house form that was associated with exploration and initial settlement, dugouts were adaptable to many varieties of climate and soil. They represented a logical response to the need for shelter when commercial building materials were not available and to a land system that imposed specific legal requirements for establishing residency.

Archer (1978:27) has pointed out that no two dugouts were exactly alike. On the other hand, it can be argued that most dugouts conformed to a general pattern insofar as types, building materials, construction techniques, and environmental settings were concerned. Basically, there were three types of dugouts. The first of these, called a straight dugout, was located completely underground, often on level prairies, and was "as large as was needed and deep enough to stand erect or in some few inches deeper . . " (Faulkner $1934:$.p.; Hoffer 1942:n.p.). A second type of dugout was the half dugout, a structure that extended approximately 4 to $6 \mathrm{ft}$ above the ground. Half of the building was in the ground while the upper portion, which might be made of sod, stone, or wood, was "similar to an ordinary house" (Faulkner 1934:n.p.; Naylor 1971:1). A third type of dugout was made by digging back into embankments. In the Trans-Pecos area of Texas, such structures were called chosas (Table 6), and they were walled with rock and covered with dirt and mesquite bushes (Carter 1927:4-5; Faulkner 1934:n.p.; Bennett 1948:8; Doshier n.d.:n.p.).

Size was the most variable aspect of dugouts, although it was rare for single rooms to exceed $16 \mathrm{ft}$ in any dimension and individual rooms more commonly measured 10xl2 ft (Lovett 1934:8; Naylor 1971:2), 12x12 ft (Naylor 1971:2), 12x14 ft (Greer 1945:2; Chenoweth n.d.: 13), 14x14 ft (Carter 1927:5), and 14x16 ft (Dorwood 1958:n.p.). The sizes of dugouts were most often determined by the structural members available to support the roof, but builders could circumvent such restrictions by joining rooms together. Thus, a dugout built by the Jones family in 1887 contained four rooms and measured $20 \times 28 \mathrm{ft}$, and the spacious Lovett dugout had seven rooms (Jones n.d.:n.p.; Lovett 1934:8). 
TABLE 6

WEST TEXAS PROPERTY TYPES: DUGOUTS

\begin{tabular}{|c|c|c|c|}
\hline $\begin{array}{l}\text { Bibliographic } \\
\text { Source }\end{array}$ & Location & $\begin{array}{l}\text { Environmental } \\
\text { Setting/Water }\end{array}$ & Description \\
\hline Bennett 1948 & Moore County & $\begin{array}{l}\text { On side of a hill/ } \\
\text { near a creek }\end{array}$ & Half dugout. \\
\hline Doshier n.d. & & $\begin{array}{l}\text { On side of a bank/ } \\
\text { near a spring or } \\
\text { running water }\end{array}$ & $\begin{array}{l}\text { Half dugout; entrance has descending steps; fireplace at rear of } \\
\text { dugout facing entrance was used for cooking. }\end{array}$ \\
\hline $\begin{array}{l}\text { Carter } 1927 \\
\text { (ref. ca. } \\
\text { early 1880s) }\end{array}$ & $\begin{array}{l}\text { Pecos County; } \\
\text { vicinity of } \\
\text { Fort Stockton }\end{array}$ & On side of a hill & $\begin{array}{l}\text { Chosa (full dugout?); ca. } 14 \times 14 \mathrm{ft} \text {; roof covered with mesquite } \\
\text { branches and dirt; rock walls; a place for a door but none present; } \\
\text { fireplace was used for cooking. }\end{array}$ \\
\hline $\begin{array}{l}\text { Jones n.d. } \\
\text { (ref. 1887) }\end{array}$ & & $\begin{array}{l}\text { In north bank of a } \\
\text { draw }\end{array}$ & $\begin{array}{l}\text { Half dugout(?); } 20 \times 28 \text { ft ( } 4 \text { rooms); upright post, center beam, plank } \\
\text { and sod roof; walls built up ca. } 2 \mathrm{ft} \text { on two sides with layered sod; } \\
\text { dirt floor overlayed with starched gunny sacks; long sliding windows }\end{array}$ \\
\hline
\end{tabular}

in south and east walls.

Atkinson 1940

(ref. ca. 1893)

Hess 1956

(ref. ca. 1890)

Greer 1945
Collingsworth

County

Texas Panhandle

area

Northwest Texas
Plank roof covered with dirt; dirt floor.

On the prairie, near breaks of a canyon to be near water and wood

Full dugout; $12 \times 14 \times 5 \frac{1}{2} \mathrm{ft}$. Roof was laid with poles, usually willow branches placed on cottonwood rafters, covered with yucca (bear grass) like shingles, and 18-24 inches of sod thrown on top. Bear grass was water repellant. Some dugouts had plank roofs. Dirt walls, some covered with gunny sacks or newspapers; dirt floor. Most dugouts 
Table 6 , continued

\begin{tabular}{|c|c|c|c|}
\hline Bibliographic & & Environmental & \\
\hline Source & Location & Setting/Water & Description \\
\hline
\end{tabular}

\section{Upfold 1945}

(ref. 1885-1905,

"dugout era")

Lovett 1934
Water 3 miles away;

had to be hauled

In side of a hill

Dug back in a bank;

Wilson 1928

(ref. early

1880s)

Hoffer 1942

Dorwood 1958

Faulkner 1934

(ref. ca. 1890) had no windows; some had glass in plank roofs. Entrances were wooden doors or substitute of canvas, hide, or gunny sacks. Fireplaces with flue were opposite doorway.

Half dugout; shingled roof; windows present.

Type unknown; each room $10 \times 12 \mathrm{ft}, 7$ rooms in all. A large cottonwood ridgepole was placed along the top after the main room was dug out in the side of a hill. Rafters of smaller cottonwood logs were attached to the ridgepole. Small willow branches were tied at right angles to the rafters. A layer of bear grass was laid over the willows. About 18-24 inches of dirt was laid on the bear grass. Walls were dirt, later covered with gunny sacks and newspapers. Floor was dirt. Fireplace was used for cooking and was made by digging at back of dugout then boring hole from top to let out smoke.

Type unknown; cottonwood logs set in and over roof; dirt thrown on top; fireplace was used for cooking.

Type unknown; deep enough to stand erect in; covered with poles, brush, hay, and dirt.

Half dugout; used for school; $14 \times 16 \mathrm{ft}$.

Three kinds of dugouts: a. straight dugout--entirely above ground; b. half dugout--extended 4-6 ft above ground. c. dugout built back in embankment and covered over. 
Table 6 , continued

$\begin{array}{llll}\text { Bibliographic } & & \text { Environmental } & \\ \text { Source } & \text { Location } & \text { Setting/Water } & \text { Description }\end{array}$

Chenoweth n.d.

Miller and

Miller 1969
In mounds of earth sometimes found in prairie

\section{Deaf Smith County on a creek \\ (IS Dugout)}

Jones 1945

Whiteside 1948

Naylor 1971

(ref. ca. 1891-

1891)
Near Canadian breaks

In side of a bank
Line camp; $12 \times 14 \times 7$ ft. A heavy cottonwood log was stretched across the opening, one end of the log resting on a post over the doorway and the other end on the ground on the opposite side. From this center beam, smaller posts (usually obtained from the china tree) were laid out to the edge of the ground on either side. Mud was filled in between the posts so that no cracks were in the roof when the covering of dry dirt was thrown on. Doorway was shoveled out and down on one side. Fireplace was used for cooking; dug in dirt wall and small tunnel dug down from outside.

Type unknown; 2 rooms.

Line camp; $6 \mathrm{ft}$ deep. Roof of split logs over; grass on top of logs; dirt heaped over all. Hole dug down to interior fireplace from outside; rock chimney built ca. 2 ft above ground.

Half dugout (?); ca. $3 \frac{1}{2} \mathrm{ft}$ underground. Walls of $8-\mathrm{ft}-\mathrm{long}$ cottonwood logs stood upright and plastered. Windows present. Fireplace dug back in the dirt; chimney made of sod; stove used for cooking.

Some used for schools. Roof of cottonwood ridgepole; planks on top; covered with dirt.. Front wall boxed up with planks. No windows present. Door present.

Half dugout; 3 rooms: $12 \times 12 \mathrm{ft}$, front room; $10 \times 12 \mathrm{ft}$, bedroom; $12 \times 12 \mathrm{ft}$, kitchen. Roof of 12-inch board and tar paper; school had shingles. Dirt floors covered with grass-stuffed sacks. Entrance, 4 steps down to floor level. 
Table 6, continued

$\begin{array}{llll}\text { Bibliographic } & & \text { Environmental } & \\ \text { Source } & \text { Location } & \text { Setting/Water } & \text { Description }\end{array}$

Hext 1932

(ref. early

1890s)

Dumont 1988

Armstrong County

\section{On edge of canyon}

(Palo Duro) ca.

$6 \mathrm{ft}$ from the edge

of cliff

Dumont 1988

Cottle County

Cottle County

Dumont 1988

Dumont 1988

Dumont 1988

Collinson 1963

Snyder, Texas

Unit 1986:6

Snyder, Texas

Unit 1986:6
Cottle County

In a bank near water

On Lloyd Mountain

Creek, 1878

On Deep Creek ca. 8

miles west of Snyder,

1878
Type unknown; ca. $5 \frac{1}{2} \mathrm{ft}$ high. Roof made of willow branches with bear grass on top like shingles; dirt put on top. Some had lumber walls. Floors of packed white gypsum rock. Windows present. Fireplace present.

Type unknown; 1 room. "Front yard" surrounded by banisters. Fireplace present.

Type unknown; canvased and papered walls; carpeted floors; door hinged on top and fastened to ceiling overhead; fireplace present.

Kitchen dugout with large rock house partly sunken in ground.

Type unknown; walls whitewashed with gypsum.

Half dugout(?); $3 \mathrm{ft}$ deep; $16 \times 20 \mathrm{ft}$. Walls lumber above ground; plastered mud below. Dug out basin then floored with lumber.

Type unknown; average $10 \times 12 \mathrm{ft}$. Roof covered with poles, mud, and soil, and supported by a ridgepole. Logs on side for support. Fireplace present; chimney dug down.

Half dugout with rock house as ranch headquarters.

Dugout. 
Table 6 , continued

\begin{tabular}{|c|c|c|c|}
\hline $\begin{array}{l}\text { Bibliographic } \\
\text { Source }\end{array}$ & Location & $\begin{array}{l}\text { Environmental } \\
\text { Setting/Water }\end{array}$ & Description \\
\hline $\begin{array}{l}\text { Snyder, Texas } \\
\text { Unit 1986:11 }\end{array}$ & Scurry County & $\begin{array}{l}\text { Source of Ennis Creek, } \\
1878\end{array}$ & Half dugout with rock house as ranch headquarters. \\
\hline $\begin{array}{l}\text { Snyder, Texas } \\
\text { Unit 1986:11 }\end{array}$ & Scurry County & $\begin{array}{l}\text { Vicinity of Rough } \\
\text { Creek, } 1879\end{array}$ & Dugout and 2-room rock house. \\
\hline $\begin{array}{l}\text { Snyder, Texas } \\
\text { Unit 1986:25 }\end{array}$ & Kent County & $\begin{array}{l}\text { On bank of Double } \\
\text { Mountain Fork }\end{array}$ & Dugout/ranch headquarters. \\
\hline $\begin{array}{l}\text { Snyder, Texas } \\
\text { Unit 1986:32 }\end{array}$ & Kent County & & Half dugout as ranch headquarters. \\
\hline $\begin{array}{l}\text { Site Form } \\
41 \mathrm{GR} 474\end{array}$ & Garza County & $\begin{array}{l}\text { On } \mathrm{NW} \text {-facing slope } \\
\text { above Double Mountain } \\
\text { Fork of Brazos }\end{array}$ & Dugout as ranch headquarters. \\
\hline $\begin{array}{l}\text { Snyder, Texas } \\
\text { Unit 1986:56 }\end{array}$ & Borden County & & Half dugout as ranch headquarters. \\
\hline Holden 1932: 72 & Crosby County & In side of creekbank & $\begin{array}{l}\text { Half dugout as ranch headquarters; ca. } 10 \times 20 \mathrm{ft} \text {. Roof of poles } \\
\text { covered with buffalo hides; walls of poles above ground level to a } \\
\text { height of ca. } 3 \mathrm{ft} \text {; no windows; fireplace on back wall used for } \\
\text { cooking. }\end{array}$ \\
\hline Holden 1970:31 & Crosby County & $\begin{array}{l}\text { On Scalawag [Home] } \\
\text { Creek }\end{array}$ & Dugout as ranch headquarters. \\
\hline Holden 1970:32 & Crosby County & On Pete Creek & Dugout as ranch headquarters. \\
\hline Holden 1970:32 & Crosby County & $\begin{array}{l}\text { In side of Catfish } \\
\text { Creek at Kyle Spring }\end{array}$ & Dugout as ranch headquarters. \\
\hline
\end{tabular}


Table 6 , continued

\begin{tabular}{|c|c|c|c|}
\hline Bibliographic & Incation & Environmental & Descrintis \\
\hline Holden 1970:32 & Crosby County & On Chimney Creek & Dugout as camp. \\
\hline Holden $1970: 33$ & Crosby County & North of Dockum Creek & Dugout. \\
\hline Holden 1970:33 & Crosby County & On Cottonwood Creek & Dugout. \\
\hline Holden $1970: 34$ & Crosby County & $\begin{array}{l}\text { On Duck Creek at mouth } \\
\text { of draw coming in from } \\
\text { the west }\end{array}$ & Dugout. \\
\hline
\end{tabular}


Construction details of dugouts followed a general pattern which included an entrance, fireplace, and roof. Entrance to dugouts was by way of an opening which might be covered with wood, canvas, hide, or gunny. Frequently, steps descended from ground level to the entrance and interior floor level (Greer 1945:2; Naylor 1971:2; Chenoweth n.d.:13). The interior floor most often was bare earth or earth covered with a material. If the surface was earth, the residents often hardened it by sprinkling and then packing the dirt (Lovett 1934:8; Atkinson 1940:n.p.; Greer 1945:2; Hess 1956:4). If materials were available, the owner often attempted to retard dust by nailing starched gunny sacks to the floor. Occasionally, a softer feeling was achieved by covering the dirt with a carpet made by stuffing grass in a sack (Naylor 1971:2; Jones n.d.:n.p.).

Furnishings were sparse, and dugouts usually did not have windows. Fireplaces were almost always present and were built by digging a hole into the back wall opposite the entrance. Another hole was then bored with a post auger or dug down from the outside to make a vent for the smoke. Sometimes rock chimneys were erected at the vent, and occasionally a chimney might be made of sod. Dugouts furnished with stoves usually had a flue pipe that was inserted in the ceiling (Carter 1927:4-5; Wilson 1928:3-4; Hext 1932:n.p.; Lovett 1934:8; Greer 1945:2; Jones 1945:n.p.; Ụfold 1945:1; Jowell 1971:3; Chenoweth n.d.:14, 15; Doshier n.d.:n.p.).

Depending on the type of dugout constructed, walls assumed a variety of appearances. West Texas chosas, for example, frequently were made of rock. A dugout near the Canadian River in the Panhandle had walls made of 8-ft-long cottonwood logs hauled from the breaks, stood upright, and plastered. Some had lumber walls, and some had walls made of layered sod or of the dirt that was excavated to create the interior space. Some builders canvased the interior walls with gunny sacks and papered them with newspapers in an effort to retard falling dirt, but this application had the drawback of providing a home for insects and snakes (Carter 1927:4; Hext 1932:n.p.; Lovett 1934:8; Greer 1945:2; Jones 1945:n.p.; Whiteside 1948:n.p.; Jones n.d.:n.p.).

The roof construction of dugouts varied, but the overall intent was to build up layers of various materials to produce a stable and weather-resistant superstructure that repelled water. One common pattern was to cut a large log (preferably of cottonwood) that served as a center beam and stretched from a lintel over the doorway to the back of the dugout where it rested on the exterior ground surface. From this center beam, smaller pieces of chinawood, cottonwood, milled lumber, or other suitable materials were laid out to the edges of the dugout and served as rafters. Willow branches might be attached to the rafters, and bear grass or yucca laid over the willow. A final layer of sod or dirt was then applied. At least one author recalls having used buffalo hides to cover a dugout roof, but bear grass was one of the most effective coverings because it had excellent water-repellant properties (Wilson 1928:3; Hext 1932:n.p.; Holden 1932:72; Lovett 1934:8; Atkinson 1940: n.p.; Hoffer 1942:n.p.; Greer 1945:2; Upfold 1945:1; Whiteside 1948:n.p.; Jowell 1971:3; Naylor 1971:1, 3; Chenoweth n.d.:13-14; Jones n.d.:n.p.).

According to Archer (1978:52), as much care was taken in selecting an appropriate site for a dugout as in constructing it. She suggested that four key landmarks often were used in site selection, landmarks that pertained to other early building types as well: the distance the occupants had to carry water, the distance to the nearest post office, the distance to the nearest railroad, and the distance to the nearest neighbor. of all those key considerations, the distance to water was perhaps the most important. Hence, the Bennett family built their dugout on the side of a hill near a creek in 1895; Jim Christian 
noted that cowboy line camps frequently were made in the side of a bank near a spring or other running water; Thornton Jones, $\mathrm{Sr}$, , built his 1887 dugout in the north bank of a draw; the IS Ranch hands built a dugout on a creek near the present site of Hereford; and the Hensleys' Crosby County dugout, built in 1879, was dug in the side of a creek bank (Wilson 1928:3; Holden 1932:72; Upfold 1945:2; Bennett 1948:8; Hess 1956:2; Jowell 1971:3; Doshier n.d.:n.p.; Jones n.d.:n.p.).

A second type of structure common to the Plains area of Texas was the sod house. Sod buildings were found in the Panhandle area where they were built by breaking grassland with a turning plow with a 12-inch share. A furrow was turned over flat and cut into 2-ft-long pieces that were allowed to dry and then laid up in walls. A large log often was used as a ridge piece, and rafters were laid from the ridge piece to the exterior walls. Brush was then laid on the rafters and covered with hay and 12 to 14 inches of dirt (Biles 1955:4144).

Sod houses often were spacious structures measuring 20-50 ft in length with approximately 2-ft-thick walls capable of bearing heavy loads. In dry climates, "soddies" could last indefinitely, especially if a coat of plaster was applied to the exterior wall surfaces (Biles 1955:44). Because they were naturally insulated, they offered the same benefit that dugouts did of providing relatively constant interior temperatures.

Logs, when they were available in creek beds and river bottoms, were used occasionally in ranch construction. Two types of $\log$ structures were common, one being the log cabin form that was utilized throughout much of Texas and the second being the less common picket form. In the cabin form, logs were hewed, notched, and laid horizontally to form walls. Cracks were filled with dirt, small rocks, or pieces of wood, and roofs were made with rafters and split shingles. Examples of such structures included Goodnight's log cabin built in Palo Duro Canyon in 1873, a cabin built north of Mobeetie in 1877, one built south of Memphis (Biles 1955:52, 76), and the $\log$ complex at the Matthews Ranch in the Cross Timbers.

The picket form of log structures employed vertical placement of the logs set on end to form walls. The walls were held in place by two horizontal timbers, one at the top of the wall and one at the foot. Examples of such structures included Rath and Hamburg's store on Tepee Creek in Motley County, a dugout with a picketed front on Richardson Creek, and Mobeetie's Grand Central Hotel (Biles 1955:52-53; Rogers 1976:20).

Dugout and $\log$ structures often were used during the initial stages of settlement and later reused as storm or root cellars, smoke or ice houses, or other secondary outbuildings within a ranch complex. They were replaced by larger, more durable structures which frequently were built of stone or milled lumber.

Stone houses, which occurred throughout West Texas, ranged from simple one-story structures to multistory mansions. Often bullt by stonemasons who had prior experience working on frontier posts or who plied their trade up and down specific river and creek drainages, such homes were durable and demonstrated considerable refinement. Several stone buildings were constructed in Hansford County on Palo Duro Creek in the 1880s by Portuguese masons, while ranch headquarters along the Colorado and Concho rivers were the work of an Irish mason. Notable homes on the Canadian River included the LX Ranch headquarters; and the Kentucky Cattle Company built a stone headquarters in Crosby County in the 1880s. T. A. Bailey's 1884 story-and-a-half native stone house was located on Sweetwater Creek, while 
Hank Smith's rock house, "Hacienda Glorieta," in Blanco Canyon was called "the finest piece of masonry ever done in this section of the country" (Biles 1955: 55-56; Rogers 1976:21; Freeman and Freeman 1981:3-8, 5-15).

With the arrival of railroads and construction of towns, lumber became increasingly available. By 1890 , all parts of Texas were within convenient freighting distance, and milled lumber became the preferred construction material for outbuildings as well as main residences. Supply points for areas west of the Cross Timbers included Dodge City for the Panhandle and, after 1881, Colorado City and Abilene for the South Plains area. Although many parts of West Texas were not serviced by rail lines until after 1910, ranchers thought nothing of driving 100 miles or more to railheads to purchase lumber and hardware. Typical bulldings of the time included simple board-and-batten or box-and-strip, single-wall structures. With the availability of clapboard siding and carpentry details, frame ranch houses in isolated rural settings often displayed the ornate architecture more often associated with contemporaneous urban residences.

Sheep and Cattle Ranching: Some Common Issues

The raising of sheep and cattle resulted in the creation of different technologies, ranges, markets, and cultural traditions, in no small part because sheep and cattle raisers were discrete groups. However, because all ranchers deal with livestock, they have shared a common history of response to market conditions, to the formulation of laws, to the in-migration of nonranching populations, and to inventions that either required behavioral changes or provided new opportunities for profitability.

Because both sheepmen and cattlemen were dependent for their livelihoods upon the availability of rangelands, laws affecting that availability and the ability of livestock to move over the range were of enormous concern. Laws during the Spanish, Mexican, and Republic of Texas periods had been favorable to stockmen because of the large tracts made available for private ownership. Furthermore, the principle of range rights that involved informal but acknowledged ownership of water sources and associated pasturelands assured the availability of what must have seemed to be limitless pasture for the raising of livestock.

In 1854 the first incursion on unlimited range rights occurred when the State Legislature offered 16 sections of land to railroad companies for every mile of track laid (Rickard 1927:105; Martin 1969:7). The State required, in return, that the railroad companies survey one section for the State for every section surveyed for the companies. At the end of the process, the railroads acquired all of the odd-numbered sections within the surveyed area and the State acquired all of the even-numbered sections. These State sections were then reserved for the benefit of the public school fund, and monies for that fund derived from the sale of the school sections according to terms set by the Legislature.

An early act to sell some of the school lands was passed in 1874 when the Legislature allowed the sale of 160 acres per individual for $\$ 1.50$ per acre. However, because the act allowed the purchaser to pay out the land and obtain a patent for it at any time after applying for the acreage, the law failed to receive the support of the Land Commissioner. He surmised correctly that the law would not encourage actual settlement and that it could be used by ranchers to acquire large holdings (Rickard 1927:114; Martin 1969:7). 
Two acts passed by the Legislature allowing for the acquisition by one person of one section of arable land or three sections of pastureland (Act of 1879) and, later, seven sections of land (Act of 1881) did nothing to correct the drawbacks of the 18741 aw. Indeed, shortly after 1881 the Commissioner announced that the General Land Office had received applications for the purchase of 1,300,000 acres and that almost all of it had ended up in the ownership of large cattle companies (Rickard 1927:115; Martin 1969:7).

About the same time, cattlemen demonstrated their power with the State Legislature by encouraging passage of a law that prohibited sheep from grazing on land that their owner had not actually purchased. While the revised statute which went into effect on July 1 , 1881, included clauses protecting owners of healthy flocks from flocks infected with scab and other diseases, one result of the law was the restriction of the movement of sheep but not of cattle and horses (Texas Wool 1881:n.p.; Towne and Wentworth 1945:137-138; Holt 1956:19).

Cattlemen found their own activities limited two years later when the Legislature passed an act that established a State Land Board, provided for leasing of grasslands, drastically increased the per-acre price of school lands and other parts of the public domain, and gave homesteaders generous credit terms. Ranchers responded by refusing to pay more than four cents per acre for grazing leases and, in effect, ignoring the law in order to continue enjoying the benefits of an open range (Rickard 1927:115-116; Wilson 1983:40).

While the 1883 Act was designed in large part to encourage acquisition of land by actual settlers, the terms that allowed ranchers to lease the land for up to 10 years made the property unavailable to homesteaders. Subsequent acts in 1887, 1889, and 1891 attempted to cure the problems of earlier acts by requiring a purchaser to swear that his or her intent was to actually establish a home. Furthermore, the Four-Section Act of 1895 required purchasers to reside on the land for three years and make specified minimum improvements. But while the 1895 Act dramatically increased the demand for land by farmers in some parts of the State, ranchers circumvented the intent of the Act in other areas by encouraging their employees to "homestead" four-section tracts which were then sold to the employer (Texas. Twenty-fourth Legislature 1895:828-839; Rickard 1927:118-120; Murrah 1981:84).

Ranchers effectively retarded acquisition of land by farmers in many parts of West Texas by controlling the land through their employees. They also prevented intrusion by farmers by a mechanism called lapse leasing in which they canceled their leases with the State before the normal expiration date when the land would have been subject to sale, and then re-leased the land for an extended period of time. Prospective buyers had no way of knowing when land became available, and ranchers were virtually assured of perpetual control of the public domain (Murrah 1981:104). Eventually, the practice of lapse leasing was challenged in the courts, and State land became available again on a regular and predictable basis. Dramatic increases in lease rates due to the initiation of a closed, competitive bidding situation put further pressures on ranchers who were still feeling the effects of the 1893 Panic and earlier drops in the cattle market (Murrah 1981:104-105, 110). As a result, open-range ranching effectively ended, and farming in West Texas began a period of significant growth.

Major contributors to the florescence of ranching and the later development of farming in West Texas were the railroads which began to move westward in the late 1870 s and early 1880s. Initially, lines such as the Corpus Christi, San Diego, and Rio Grande which reached Laredo in 1881, the Texas and Pacific (see Fig. 2) which ran southwest from Dallas 
to join the Southern Pacific at Sierra Blanca in 1882, and the Santa Fe which completed track to San Angelo in 1888 facilitated the migration of ranchers, the shipping of cattle from range to market, and the importation of goods to the frontier. By the late 1880s, however, it was also clear that railroads were providing the means for opening the ranching frontier to farmers. Towns and markets that developed along rail lines such as the Texas and Pacific--Abilene, Sweetwater, Colorado City, Big Spring, and Midland--not only became major shipping points for the products of the industry, but they also became jumping-off points for homesteaders who intended to acquire portions of what had previously been open range (Mooar 1929:124; Jordan 1981:157; Murrah 1981:37; Carlson 1982:84, 110; Wilson $1983: 19)$.

The end of open-range ranching resulted in large part from land laws that encouraged homesteading and railroads that facilitated the in-migration of farmers. The disappearance of open pastures also was directly related to certain improvements in technology and animal breeding. According to Jordan (1981:22), barbed wire allowed the fencing of open ranges, while windmills increased the carrying capacity of grasslands and opened certain areas of the Plains that had been underutilized due to a paucity of surface water. Such inventions also allowed the introduction of improved livestock, the control of which was facilitated by barbed wire.

Barbed wire fencing, invented in 1874, was sufficiently widespread by the early 1880s to spark a fence-cutting war. Both sheep and cattle ranchers suffered the effects of the war, and both benefited from a special session of the State Legislature that outlawed fence cutting in 1884 (Wilson 1983:40). Sheepmen soon realized that the control of animals which fencing made possible increased range productivity, increased the number of sheep that could be handled per section, and reduced the number of employees required to herd the flocks. Cattlemen, who had invested heavily in improved stock during the early 1880s, appreciated the fact that their high-grade bulls would no longer be improving the genetics of neighboring herds free of charge.

Use of windmills, which was a natural outgrowth of fencing and essential to successful closed-range ranching, was widespread in the Edwards Plateau area by the 1880s, on the Rolling Plains in the 1890s, and throughout the Southern Plains area by World War I. While windmills facilitated irrigation and thus made farming possible on land previously used only for ranching, they also increased the intensity with which ranchers could utilize their ranges by encouraging stock dispersal. By the early twentieth century, the ranching effort of the open-range era had become a sophisticated, intensive form of livestock raising. Ranchers had succeeded in capitalizing on many of the technological inventions that had made such a dramatic impact on their industry in the 1880s (Jones 1936:75; Jordan 1981:22; Murrah 1981:69; Carlson 1982:111).

\section{Ranching on the Western Rolling Plains, 1877-1945}

Ranching on the western Rolling Plains, an area that Jones and Richardson (1943:36-37) characterized as "a cattleman's paradise," began in the late 1870s with the disappearance of large buffalo herds and hostile Indians. Utilization of the range accelerated rapidly in the next decade as ranchers immigrated to the area from the Cross Timbers region, and railroad companies and the State began to lease sections for grazing. By 1885, a multitude 
of individual and company-owned ranching outfits had moved into the sheltered, wellwatered, grass-covered breaks of the White River and the North Fork and Double Mountain Fork of the Brazos River (Table 7; Fig. 3).

Ranching was the primary occupation on the western Rolling Plains until 1900 when railroad construction and land laws that encouraged property ownership resulted in a largescale in-migration of homesteaders. Some arrivals after 1899 came with the intention of ranching; others, who settled in the flatter areas back from major drainages, were interested primarily in farming. All of the recent arrivals found themselves in competition with well-established ranchers who maintained control of pastures initially by arranging for their employees to homestead the open range. Completion of the Santa Fe Railroad through the area in 1910 resulted in the platting of new towns and the immigration of families who hoped to farm the area east of the Caprock. By World War I, Post and Fluvanna in Garza and Scurry counties had become centers for communities of farmers, while ranches such as the Spur in Dickens, Kent, Crosby, and Garza counties were the locations of agricultural experimentation and the cultivation of crops suited to livestock feeding.

Open-range Ranching, 1877-ca. 1890

The Rolling Plains, an area described by Pool (1975:8) as encompassing 24.5 million acres, features short and bunch grasses and is utilized today for ranching and for growing cotton and small grains. The western portion of the Rolling Plains adjacent to the Caprock is characterized by rolling grasslands, low ridges, and broken, eroded hills. Historical$1 y$, the area was the location of numerous springs that flowed from the base of the Caprock and were fed by water contained in the Ogallala aquifer. Canyons at the spring-fed heads of creeks and rivers provided shelter, and a combination of fertile soils and adequate rainfall supported growths of bluestem, buffalo, and grama grasses (Pearce 1964:3-4; Holden 1970:1).

The region was a stockman's paradise, and ranchers were not long in recognizing the fact. By the mid 1870s, men such as Jesse Hittson, the Slaughters, and the Daltons had begun to move west from Palo Pinto County. Hensley, Crutchfield, and the Coopers came from Jack County. George Edwards, Dan Cole, and Hank Smith left the vicinity of Fort Griffin; and Clay Mann, G. K. Elkins, and W. B. (Smokey) Brown came from Coleman, Runnels, and Callahan counties (Biggers 1944:49; Williams 1954:55) (see Table 7 and Fig. 3).

For the most part, the new immigrants were cattlemen, but some sheepmen ventured into the area as well (see Table 7). One archeological site (41GR443) suggests that the region may have been used by herders associated with ranches in or adjacent to the western Rolling Plains. In the late 1870s, C. C. Slaughter established his temporary ranch headquarters near some rock corrals about 13 miles southwest of present-day Snyder in Scurry County; in 1881 he moved his headquarters about 20 miles north of present-day Big Spring where he used "scattered sheepherder dugouts" as dwellings for his camp (Murrah 1981:41). Mitchell County and the vicinity of Colorado City also were the locations of several sheep ranches by 1881, and the editor of Texas Wool wrote that while "there are very few sheep north of here [Mitchell County] . . . there are a great many situations suitable for sheep raising in this country" (Texas Wool 1881). In 1882, the Eaheart Brothers of Shackelford County trailed sheep from the Las Vegas, New Mexico, area to Colorado City (Maxwel1 1954:157), and sheep drifters were reported in Scurry County in 1884 (Havins 1952:19). 
TABLE 7

SELECTED RANCHES ON THE WESTERN ROLLING PLAINS*

\begin{tabular}{|c|c|c|c|c|c|}
\hline Ranch (Brand) & Location & Owner (s) & Origin(s) & Date (s) & Improvements \\
\hline \multirow[t]{3}{*}{$\begin{array}{l}\text { Nunn Brothers } \\
\text { (NUN) }\end{array}$} & $\begin{array}{l}\text { Camp Springs, } \\
\text { Scurry County }\end{array}$ & $\begin{array}{l}\text { John W., Thomas N., and } \\
\text { James H. Nunn, late } \\
\text { 1870s-1890 (lost every- } \\
\text { thing after blizzard and } \\
\text { drought of mid 1880s) }\end{array}$ & $\begin{array}{l}\text { Washington County } \\
\text { (Brenham) }\end{array}$ & 1877 & Camp \\
\hline & $\begin{array}{l}\text { Lloyd Mt. Creek, } \\
\text { Scurry County }\end{array}$ & & . & 1878 & $\begin{array}{l}\text { Half dugout and rock } \\
\text { house }\end{array}$ \\
\hline & $\begin{array}{l}\text { near Rich Lake, } \\
\text { NE Terry County }\end{array}$ & & & ca. 1885- & Ranch headquarters \\
\hline \multirow[t]{2}{*}{$\begin{array}{l}\text { Elkins Ranch } \\
\qquad(\mathrm{K} / \mathrm{N})\end{array}$} & Kent County & George Elkins & $\begin{array}{l}\text { (Illinois) } \\
\text { Coleman County }\end{array}$ & 1877 & $\begin{array}{l}\text { Dugout on Double Mountain pre- } \\
1883 \text {; frame house post-1883 } \\
\text { (1-story board and batten } \\
\text { with chimney) }\end{array}$ \\
\hline & & Kin Elkins & . & 1879 & \\
\hline $\begin{array}{l}\text { Clay Mann } \\
\qquad(80)\end{array}$ & $\begin{array}{l}\text { Kent and Scurry } \\
\text { counties; head- } \\
\text { quarters moved } \\
\text { to Colorado City } \\
\text { in ca. } 1881\end{array}$ & Clay Mann & $\begin{array}{l}\text { (Tennessee) } \\
\text { Coleman County }\end{array}$ & ca. 1877 & House ca. late 1880 s, frame \\
\hline
\end{tabular}

*Compiled from information in Holden (1970) and Snyder, Texas Unit (1986). 
Table 7, continued

\begin{tabular}{|c|c|c|c|c|c|}
\hline Ranch (Brand) & Location & Owner (s) & Origin(s) & Date (s) & Improvements \\
\hline $\begin{array}{l}\text { Long S Ranch } \\
\qquad(\infty)\end{array}$ & $\begin{array}{l}\text { Borden, Howard, } \\
\text { Martin, Dawson, } \\
\text { and Lynn counties }\end{array}$ & C. C. Slaughter & $\begin{array}{l}\text { Sabine County } \\
\text { Freestone County } \\
\text { Palo Pinto County }\end{array}$ & 1878 & $\begin{array}{l}\text { Temporary headquarters near } \\
\text { old rock corrals at mouth of } \\
\text { Bull Creek (a dugout); head- } \\
\text { quarters moved in } 1881 \text { to } \\
\text { German Spring, } 20 \text { miles north } \\
\text { of Big Spring }\end{array}$ \\
\hline Smokey Brown Ranch & $\begin{array}{l}\text { Garza County } \\
\text { Alamo River } \\
\text { (Sand Creek) }\end{array}$ & Smokey Brown & . & ca. 1877 & \\
\hline $\begin{array}{l}\text { Dockum Ranch } \\
\text { (DOX) }\end{array}$ & Dickens County & W. C. Dockum & & 1877 & $\begin{array}{l}\text { Half dugout store for buffalo } \\
\text { trade at head of creek; cow } \\
\text { camp }\end{array}$ \\
\hline $\begin{array}{l}\text { Tasker-Smith Ranch } \\
\text { (Hacienda Glorieta) }\end{array}$ & Crosby County & $\begin{array}{l}\text { Charles P. Tasker, Henry } \\
\text { C. ("Uncle Hank") Smith }\end{array}$ & $\begin{array}{l}\text { Pennsylvania } \\
\text { Fort Griffin }\end{array}$ & 1877 & $\begin{array}{l}\text { Cow camp in canyon; 2-story } \\
\text { stone house }\end{array}$ \\
\hline $\begin{array}{l}\text { W. A. Johnson } \\
(\forall)\end{array}$ & $\begin{array}{l}\text { Scurry County } \\
\text { Head of Ennis } \\
\text { Creek }\end{array}$ & W. A. Johnson & $\begin{array}{l}\text { Gonzales County, } 1862 \\
\text { Burnet County }\end{array}$ & $\begin{array}{l}1878 \\
1890 \text { s(?) }\end{array}$ & $\begin{array}{l}\text { Half dugout and rock house; } \\
\text { 2-story frame, Victorian house } \\
\text { with rock and brick chimneys }\end{array}$ \\
\hline $\begin{array}{l}22 \text { Ranch } \\
\text { Paddle Ranch }\end{array}$ & $\begin{array}{l}\text { Crosby County } \\
\text { (Turkey Creek) }\end{array}$ & $\begin{array}{l}\text { John Hensley } \\
\text { L. A. (Fait) Wilson }\end{array}$ & Jack County & $\begin{array}{l}1878, \\
1879\end{array}$ & $\begin{array}{l}\text { Half dugout on a draw at a } \\
\text { spring } 4 \mathrm{ft} \text { deep; upper } 3 \mathrm{ft} \\
\text { made of cottonwood logs; roof } \\
\text { poles covered with buffalo } \\
\text { hides, dimensions } 10 \times 20 \mathrm{ft}\end{array}$ \\
\hline Jumbo Ranch - & $\begin{array}{l}\text { Borden and Garza } \\
\text { counties }\end{array}$ & $\begin{array}{l}\text { J. T. Davis } \\
\text { J. T. Beal } \\
\text { J. H. Drennan }\end{array}$ & $\begin{array}{l}\text { Marlin, Texas } \\
\text { Calvert, Texas } \\
\text { Calvert, Texas }\end{array}$ & $\begin{array}{l}\text { ca. } 1879- \\
\text { ca. } 1894- \\
1900 \text { (Block } \\
97 \text { opened } \\
\text { for settlers) }\end{array}$ & $\begin{array}{l}4 \text { line camps: } 1 \text { near present- } \\
\text { day Gail, } 1 \text { near present-day } \\
\text { Post, } 2 \text { near present-day } \\
\text { Fluvanna }\end{array}$ \\
\hline
\end{tabular}


Table 7, continued

\begin{tabular}{|c|c|c|c|c|c|}
\hline Ranch (Brand) & Location & Owner (s) & Origin(s) & Date (s) & Improvements \\
\hline $\begin{array}{l}\text { Llano Cattle } \\
\text { Company } \\
\qquad(ய U)\end{array}$ & Garza County & $\begin{array}{l}\text { W. C. Young and Ben } \\
\text { Galbraith }\end{array}$ & Fort Worth & $\begin{array}{l}1879 \\
1883\end{array}$ & $\begin{array}{l}\text { Half dugout on Yellow House } \\
\text { Creek } \\
\text { 2-story frame house; lumber } \\
\text { hauled from Colorado City; } \\
\text { relocated south of present-day } \\
\text { Post }\end{array}$ \\
\hline $\begin{array}{l}\text { Diamond Cross } \\
\text { Ranch }\end{array}$ & $\begin{array}{l}\text { Kent-Garza Co. } \\
\text { line (center of) }\end{array}$ & George Womack & . & 1879 & \\
\hline $\begin{array}{l}\text { Slaughter Ranches } \\
\text { (WILL) }\end{array}$ & Crosby County & Will Slaughter & Palo Pinto County & 1879 & $\begin{array}{l}\text { 4-room, unpainted box-and- } \\
\text { strip house, "T" floor plan, } \\
\text { near Hensley's Spring; lumber } \\
\text { freighted from Fort Worth }\end{array}$ \\
\hline $\begin{array}{l}\text { Petty Ranch } \\
\text { (COE) }\end{array}$ & Crosby County & Ed and Bill Petty & & 1879 & Camp at a spring \\
\hline $\begin{array}{l}\text { Slaughter Ranch } \\
(\text { JOHN U) }\end{array}$ & $\begin{array}{l}\text { Crosby County on } \\
\text { McDonald Creek } \\
\text { Near Socorro, N.M. } \\
30 \text { miles E of } \\
\text { Salt Lake City } \\
\text { SE New Mexico } \\
\text { Glasscock County }\end{array}$ & John B. Slaughter & $\begin{array}{l}\text { Sabine County } \\
\text { Palo Pinto County }\end{array}$ & $\begin{array}{l}1879 \\
1884 \\
1886 \\
\\
1888 \\
1890\end{array}$ & Dugout on creek \\
\hline $\begin{array}{l}\text { U Lazy S } \\
\text { (UU) }\end{array}$ & $\begin{array}{l}\text { Garza and Borden } \\
\text { counties }\end{array}$ & John B. Slaughter & & 1901 & $\begin{array}{l}\text { Ranch headquarters } 10 \text { miles } \\
\text { south of Post near Double } \\
\text { Mountain Fork }\end{array}$ \\
\hline
\end{tabular}


Table 7, continued

\begin{tabular}{|c|c|c|c|c|c|}
\hline Ranch (Brand) & Location & Owner (s) & Origin(s) & $\operatorname{Date}(\mathrm{s})$ & Improvements \\
\hline $\begin{array}{l}\text { Slaughter Ranch } \\
\text { (PU) }\end{array}$ & Crosby County & Peter E. Slaughter & Palo Pinto County & 1879 & Dugout on creek \\
\hline $\begin{array}{l}\text { Slaughter Ranch } \\
\text { (MY U) }\end{array}$ & Crosby County & Mace Slaughter & Palo Pinto County & 1879 & \\
\hline $\begin{array}{l}\text { Kyle Ranch } \\
\qquad(\text { KKK) }\end{array}$ & Garza County & Dan C. Kyle & Palo Pinto County(?) & 1879 & Dugout on creek \\
\hline Dalton Ranch (es) & $\begin{array}{l}\text { Garza County } \\
\text { Kent County }\end{array}$ & $\begin{array}{l}\text { Charles A., George W., } \\
\text { Robert S., Will C., and } \\
\text { Lee Dalton }\end{array}$ & Palo Pinto County & 1879 & 2 camps, 1 a dugout on creek \\
\hline $\begin{array}{l}\text { Two Circle Bar } \\
\text { (이) }\end{array}$ & $\begin{array}{l}\text { Kent County } \\
\text { Stonewall County } \\
\text { NE Scurry County } \\
\text { NW Fisher County }\end{array}$ & $\begin{array}{l}\text { J. J. Hittson } \\
\text { (O. J. Wiren) }\end{array}$ & & 1879 & \\
\hline Williams Ranch* & Crosby County & Z. T. Williams & 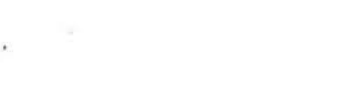 & ca. 1879 & $\begin{array}{l}\text { Rock sheep corral and boxed } \\
\text { house on creek }\end{array}$ \\
\hline $\begin{array}{l}\text { Sims Ranch } \\
\qquad(\psi)\end{array}$ & Scurry County & W. D. Sims & Burnet County & 1879 & \\
\hline Lindsey & $\begin{array}{l}\text { Double Mountain } \\
\text { Fork at mouth of } \\
\text { Middle Creek in } \\
\text { Garza County } \\
\text { ( } 1880 \text { Census) }\end{array}$ & Jim and Finis Lindsey & & pre-1880 & \\
\hline
\end{tabular}

*Sheep ranch. 
Table 7, continued

\begin{tabular}{|c|c|c|c|c|c|}
\hline Ranch (Brand) & Location & Owner (s) & $\operatorname{Origin}(\mathrm{s})$ & Date (s) & Improvements \\
\hline $\begin{array}{l}\text { Pyron Ranch } \\
(\overline{81})\end{array}$ & Scurry County & $\begin{array}{l}\text { R. B. (Bob) Pyron (lost } \\
\text { ranch to St. Louis bank) }\end{array}$ & Lampasas & $1880 s-1905$ & 2-story frame house \\
\hline J Buckle Ranch & $\begin{array}{l}\text { [Double Mountain } \\
\text { Fork] }\end{array}$ & John Powers & & 1880 & \\
\hline $\begin{array}{l}\text { OS Ranch } \\
\text { (OS) }\end{array}$ & Garza County & $\begin{array}{l}\text { Overall \& Street; Frank } \\
\text { and Andy Long; Connell, } \\
\text { Clark \& Scharbauer; } \\
\text { Connell }\end{array}$ & & 1881 & \\
\hline Square and Compass & $\begin{array}{l}\text { Double Mountain } \\
\text { Fork at mouth of } \\
\text { Middle Creek in } \\
\text { Garza County }\end{array}$ & $\begin{array}{l}\text { Abram Nave and James } \\
\text { McCord }\end{array}$ & St. Louis, Mo. & $1882-1901$ & \\
\hline $\begin{array}{l}\text { Magnolia Cattle } \& \\
\text { Land Company } \\
\quad(M K)\end{array}$ & $\begin{array}{l}\text { Borden, Howard, } \\
\text { Dawson, and Garza } \\
\text { counties }\end{array}$ & Major Willa V. Johnson & Louisville, Ky. & ca. 1882- & Frame house \\
\hline $\begin{array}{l}\text { Lexington Cattle } \\
\text { Co. }\end{array}$ & Garza County & $\begin{array}{l}\text { F. M. Smith, President } \\
\text { German B. Stout, Manager }\end{array}$ & Kentucky & pre-1883 & \\
\hline Cooper Ranch & Garza County & Harry Cooper & & pre-1883 & \\
\hline $\begin{array}{l}\text { Moore Ranch } \\
\text { (LANC) }\end{array}$ & Crosby County & W. R. Moore & & pre-1883 & \\
\hline Gholson Ranch & Crosby County & Sam Gholson & & pre-1883 & \\
\hline Beal Ranch. & Crosby County & Henry Beal & & pre-1883 & Dugout at mouth of creek \\
\hline
\end{tabular}


Table 7, continued

\begin{tabular}{|c|c|c|c|c|c|}
\hline Ranch (Brand) & Location & Owner(s) & Origin(s) & Date (s) & Improvements \\
\hline $\begin{array}{l}\text { Kidwell Ranch } \\
\text { (KID) }\end{array}$ & Crosby County & Kidwell Brothers & & pre-1883 & \\
\hline $\begin{array}{l}\text { Bush and Tillar's } \\
\text { Triangle Ranch } \\
\text { (Alabama-Texas } \\
\text { Cattle Company) } \\
\quad(\Delta H \Delta)\end{array}$ & $\begin{array}{l}\text { Scurry, Mitchell, } \\
\text { and Borden } \\
\text { counties }\end{array}$ & $\begin{array}{l}\text { A. P. Bush, Jr., and Ben } \\
\text { J. Tillar, 1883-mid } 1890 \text { s } \\
\text { (Bush failed to recover } \\
\text { from } 1886 \text { drought) }\end{array}$ & Alabama & 1883 & 2-story house, frame \\
\hline $\begin{array}{l}\text { Spur Ranch } \\
\text { (Espuela Land \& } \\
\text { Cattle Co.) (The } \\
\text { Espuela Land \& } \\
\text { Cattle Co., Ltd. } \\
\text { of London) } \\
\text { (Y) }\end{array}$ & $\begin{array}{l}\text { Dickens, Kent, } \\
\text { Crosby, and Garza } \\
\text { counties }\end{array}$ & $\begin{array}{l}\text { A. M. Britton, Denver, } \\
\text { and S. W. Lomas, } \\
\text { Missouri/Fort Worth; } \\
\text { Espuela Land \& Cattle Co. }\end{array}$ & $\begin{array}{l}\text { Denver, Missouri, } \\
\text { Fort Worth }\end{array}$ & $\begin{array}{l}1883-1884 \\
\text { to } 1908\end{array}$ & \\
\hline Boot Ranch & Crosby County & Unknown & & pre-1884 & \\
\hline Overhulse Ranch & Dickens County & Overhulse & . & pre-1884. & Dugout \\
\hline Campbell Ranch & Dickens County & A. T. (Bud) Campbell & & pre-1884 & Dugout on creek \\
\hline Wear Ranch & Dickens County & George and Fred Wear & $\therefore$ & pre-1884 & \\
\hline Groff Ranch & Dickens County & Charles L. Groff & & pre-1884 & \\
\hline $\begin{array}{l}\text { Davis Ranch } \\
\quad(\mathrm{JC})\end{array}$ & Dickens County & J. C. Davis & & pre-1884 & $\begin{array}{l}\text { Dugout (ranch headquarters and } \\
\text { store) }\end{array}$ \\
\hline $\begin{array}{l}\text { Hensley Ranch } \\
\text { (SPADE) }\end{array}$ & Dickens County & $\begin{array}{l}\text { Hensley Brothers (nephews } \\
\text { of John and Charles }\end{array}$ & & pre-1884 & Dugout at mouth of draw \\
\hline
\end{tabular}


Table 7, continued

\begin{tabular}{|c|c|c|c|c|c|}
\hline Ranch (Brand) & Location & Owner (s) & Origin(s) & Date (s) & Improvements \\
\hline $\begin{array}{l}\text { Oliver and Shelton } \\
\text { Ranch (747) }\end{array}$ & Dickens County & Oliver and Shelton & & pre-1884 & \\
\hline $\begin{array}{l}\text { Gambel Ranch } \\
\text { (MT-) }\end{array}$ & Kent County & George Gambel & & pre-1884 & \\
\hline $\begin{array}{l}\text { Browning Ranch } \\
\text { (FLYNGA) }\end{array}$ & Kent County & W. L. (Bud) Browning & & pre-1884 & \\
\hline $\begin{array}{l}\text { Edwards Ranch } \\
\text { (OPEN DIAMOND OA) }\end{array}$ & Kent County & Cass and George Edwards & . & pre-1884 & \\
\hline J 2 Ranch & Dickens County & Jessie Jones & & pre-1884 & \\
\hline Sullivan Ranch & Dickens County & Mike Sullivan & & pre-1884 & \\
\hline Stephens and Harris & Dickens County & Stephens & & pre-1884 & \\
\hline Heslip Ranch & Dickens County & John Heslip & & pre-1884 & \\
\hline Power Ranch & Dickens County & Richard Power & . & pre-1884 & \\
\hline Cole Ranch & Garza County & Don C. Cole & & pre-1884 & \\
\hline 24 Ranch & Kent County & $\begin{array}{l}\text { Boley Brown \& } \\
\text { Pete Scoggins }\end{array}$ & $\begin{array}{l}\text { (Illinois) } \\
\text { Coleman County } \\
\text { (North Carolina) } \\
\text { Coleman County }\end{array}$ & ca. 1884 & $\begin{array}{l}\text { Half dugout, small house ca. } \\
11 \text { miles } \mathrm{W} \text { of } \mathrm{Claremont} \text {, then } \\
\text { 2-story frame Victorian house }\end{array}$ \\
\hline OS Ranch & $\begin{array}{l}\text { Garza County } \\
\text { (former } \\
\text { Lexington Cattle } \\
\text { Co. range) }\end{array}$ & $\begin{array}{l}\text { Frank \& Andy Long; } \\
\text { Scharbauer, Clark \& } \\
\text { Connell; } \\
\text { Connell }\end{array}$ & & $\begin{array}{l}1884-1901 \\
1901-1909 \\
1913-\end{array}$ & \\
\hline
\end{tabular}


Table 7, continued

\begin{tabular}{|c|c|c|c|c|c|c|}
\hline Ranch (Brand) & Location & Owner (s) & Origin(s) & & Date (s) & Improvements \\
\hline $\begin{array}{l}\text { J. J. Koonsman } \\
\text { Ranch }\end{array}$ & $\begin{array}{l}\text { Scurry County } \\
\text { (Rough Creek) }\end{array}$ & J. J. Koonsman & & & $\begin{array}{l}1884 \\
1887\end{array}$ & $\begin{array}{l}\text { Dugout on creek bank } \\
\text { l-story frame house; lumber } \\
\text { hauled from Colorado City; } \\
\text { demolished } 1946\end{array}$ \\
\hline Mooar Brothers & $\begin{array}{l}\text { Scurry County } \\
\text { Deep Creek, } 10 \\
\text { miles NW of } \\
\text { Snyder }\end{array}$ & $\begin{array}{l}\text { John W. and J. Wright } \\
\text { Mooar }\end{array}$ & & . & 1885 & Ranch headquarters \\
\hline $\begin{array}{l}\text { Mooar Brothers } \\
\text { and Shannon }\end{array}$ & $\begin{array}{l}\text { Scurry County, } \\
\text { Deep Creek, } 10 \\
\text { miles NW of } \\
\text { Snyder }\end{array}$ & $\begin{array}{l}\text { John W. and J. Wright } \\
\text { Mooar, J. M. Shannon }\end{array}$ & & & late 1890 s & \\
\hline JY Ranch & $\begin{array}{l}\text { Borden County } \\
\qquad \\
\qquad\end{array}$ & Joe S. York & $\begin{array}{l}\text { (Virginia) } \\
\text { Mills County }\end{array}$ & & $1890-$ & $\begin{array}{l}\text { Half dugout, box-and-strip } \\
\text { building for school and } \\
\text { church ca. } 1 \frac{1}{2} \text { miles } \mathrm{N} \text { of half } \\
\text { dugout, frame headquarters } \\
\text { building }\end{array}$ \\
\hline Wasson Ranch* & Borden County & Wasson family & & $\ldots$ & 1890,1895 & \\
\hline $\begin{array}{l}\text { 9R Ranch } \\
\text { (9R) }\end{array}$ & $\begin{array}{l}\text { Borden and Scurry } \\
\text { counties }\end{array}$ & Thomas Trammell & $\begin{array}{l}\text { (Arkansas) } \\
\text { Sweetwater, } \\
\text { Nolan County }\end{array}$ & & $\begin{array}{l}\text { ca. } 1893-1915 \\
\text { (financial } \\
\text { reverses) }\end{array}$ & $\begin{array}{l}\text { Headquarters building (burned } \\
\text { ca. 1930), large barn (built } \\
\text { ca. 1910), and adobe meat and } \\
\text { milk house }\end{array}$ \\
\hline $\begin{array}{l}\text { Justice Ranch } \\
\text { (JEF) }\end{array}$ & Garza County & Jeff Justice & Scurry County & & $\begin{array}{l}\text { ca. } 1899 \\
\text { post-1900 }\end{array}$ & $\begin{array}{l}\text { Dugout } \\
\text { Frame house }\end{array}$ \\
\hline
\end{tabular}

*Sheep ranch. 
Table 7, continued

Location

Owner (s)

Origin(s)

$\operatorname{Date}(\mathrm{s})$

Improvements

Willians Ranch

Garza County

Will G. Williams

Gadalupe County, Hamilton County

Roy Ranch

Garza County

Walter Roy

Garza County

O. H. Curtis

1900

1900

ca. 1899

Dugout

Curtis Ranch

Dugout at head of draw

Dugout in level area near a spring 


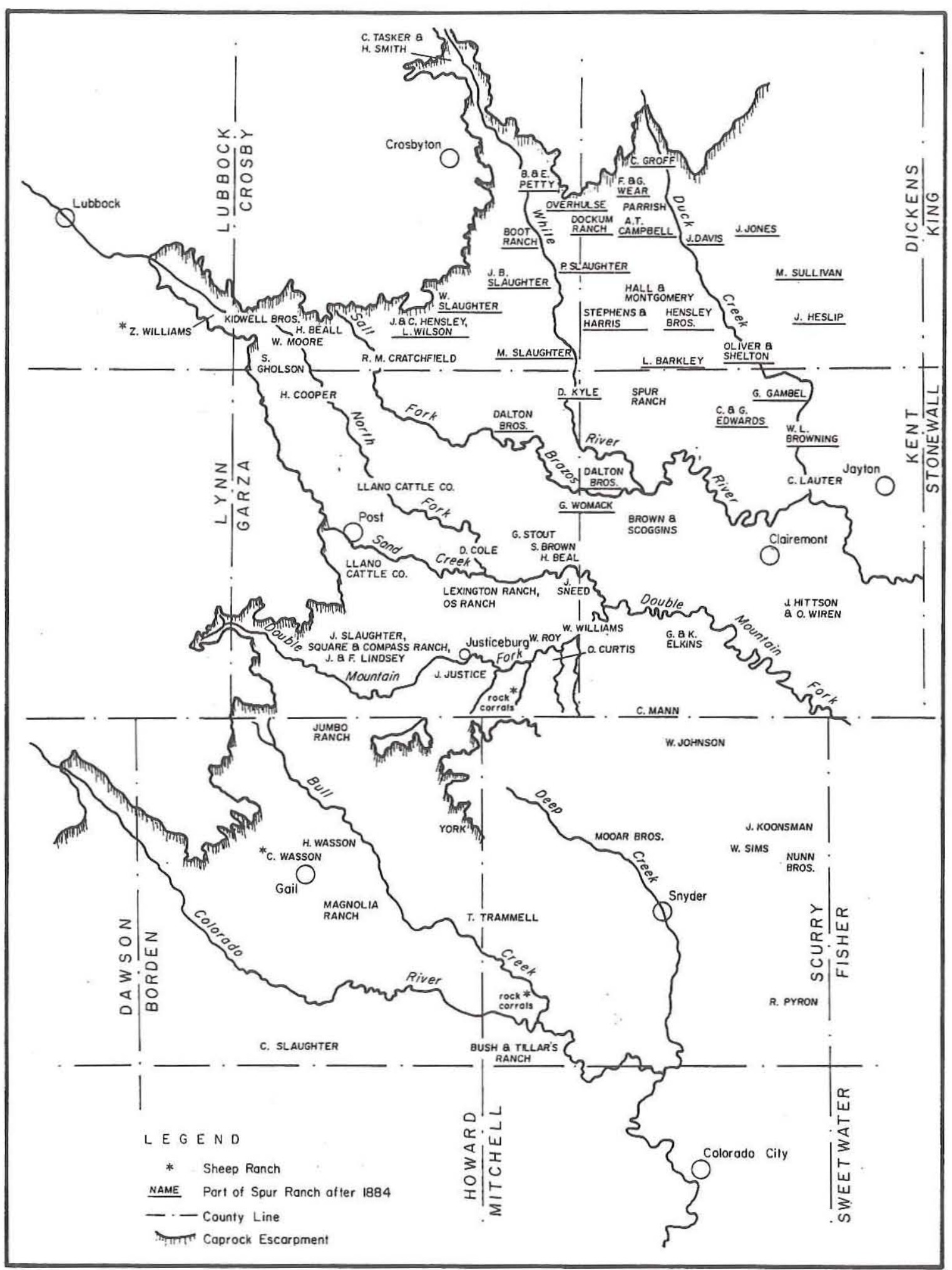

Figure 3. Ranches on the western Rolling Plains, from 1877. Compiled from information in Holden (1970) and Snyder, Texas Unit (1986). 
On the north end of the western Rolling Plains, Z. T. Williams established a sheep ranch consisting of a rock sheep corral and a boxed house on Yellow House Draw (the North Fork of the Double Mountain Fork) where "a good spring of water high up on the cliff made the location a desirable one" (Holden 1932:75). A decade later, in 1890, C. L. Wasson purchased a section from the State that lay within the Magnolia Ranch of Borden County. According to a suit brought by the Magnolia, Wasson "was permitting his cattle, horses and sheep to range in the daytime on [the Magnolia] and only penned the sheep at night on Survey 24" (Dennis 1971:2). The Magnolia lost the suit in 1891, but Wasson was asked to restrict the movement of his sheep to the section that he actually owned (Snyder, Texas Unit 1986:48). Northeast of Wasson, in southern Kent County, George Elkins ran goats with his cattle (Snyder, Texas Unit 1986:24).

While sheep ranchers were relatively scarce in the western Rolling Plains, cattle ranches were numerous (see Table 7 and $\mathrm{Fig} .3$ ). At the north end of the region in an area watered by Duck, Catfish, and Yellow House creeks and the Salt Fork of the Brazos, approximately 50 cattlemen moved onto the range between 1878 and 1884. A number of these individuals were from Jack and Palo Pinto counties, were members of the same family, and moved to the western Rolling Plains together or sequentially. Most of them built small dugouts along draws and creeks that were tributaries to major sources of fresh water. Among these cattlemen, most of whom were in the area by 1880, were John and Charles Hensley; Will, John, Pete, and Mace Slaughter; Ed and Bill Petty; Dan Kyle; G. L. and R. S. Dalton and H. P. (Handy) Cole; A. T. (Bud) Campbell; Cass and George Edwards; and Charles Lauter. Ranches on the Yellow House in Garza County from southeast to northwest included those of John W. Sneed, Henry Beal, German B. Stout, Don C. Cole, Young and Galbraith, and Henry Cooper. Sam Gholson, W. R. Moore, Henry Beal, the Kidwell Brothers, and Z. T. Williams were located on the Yellow House in Crosby County (Holden 1932:72-75, 1970:end papers, 30-35).

The southern portions of Garza and Kent counties were the locations of other major ranches owned by Smokey Brown, George Elkins, Andy and Frank Long who had bought out the holdings of Overall and Street in the early 1880s, Jim and Finis Lindsey whose ranch became the Square and Compass in 1882 and was later acquired by John B. Slaughter, Clay Mann who marrled George Elkins' sister, and 0 . J. Wiren whose holdings extended into the northeastern portion of Scurry County and northwestern portion of Fisher County (Holden 1932:76-77; Williams 1954:52-53). In Scurry and Borden counties, early ranchers and cattle companies included W. A. Johnson, John Nunn, Bush and Tillar, Mooar Brothers, the Jumbo and Magnolia cattle companies, and C. C. Slaughter who became one of the first cattlemen to venture from the breaks of the Rolling Plains onto the Llano Estacado (Murrah 1981:36; Snyder, Texas Unit 1986).

Biggers (1944:51) noted that after 1880, "ranches began to multiply rapidly and it was only about three years until the whole western country was overstocked." Since the boom era on the western Rolling Plains occurred before fencing was widely used, cattlemen developed a body of custom in which range rights were established by occupation and recognized by other ranchers as long as the range was used and defended. According to Pearce (1964:8-9):

It was generally accepted that a rancher controlling a stream or one of its banks held range rights on the land extending away from the stream to the divide separating his stream basin from an adjacent watershed. Efforts were made to keep cattle within recognized ranges by a system 
of patrolling called "line riding," since no fences were present to separate the holdings of neighboring cattlemen and cattle were no respecters of boundaries.

As late as 1883, fencing was sporadic in the western Rolling Plains, and a combination of ample water, good grass, and high beef prices made the early 1880s among the best years for free-range ranchers. At the same time, construction of the Texas and Pacific Railroad westward from Fort Worth and the establishment of railheads boosted the livestock market by facilitating the movement of cattle from the range to major cities.

The town that benefited the most from the livestock boom and, in turn, that had the greatest impact on Rolling Plains ranching was Colorado City. Formerly an area occupied by buffalo hunters' camps and, later, ranchers attracted to plentiful grass and water, Colorado City was established in anticipation of the construction of the Texas and Pacific Railroad from Fort Worth. Between 1881 when the first train arrived at the townsite and the mid 1880s when unfavorable weather and competition from other towns triggered an economic collapse, Colorado City was the shipping and supply headquarters for West Texas. Prior to 1881, ranchers had to obtain supplies from Fort Griffin, Weatherford, Fort Worth, and the few small stores that were a legacy of the buffalo range of the 1870s (see Fig. 2). Colorado City, in contrast, supplied ranches from 1881 to 1885 in the present-day counties of Mitchell, Scurry, Fisher, Stonewall, Kent, Dickens, Motley, Crosby, Garza, Lubbock, Lynn, Cochran, Yoakum, Lamb, Hockley, Bailey, Floyd, Terry, Andrews, Gaines, Dawson, Borden, Martin, Sterling, Coke, Glasscock, and Reagan. The nearest trade competitors were Dodge City, Kansas, Springer, New Mexico, and Trinidad, Colorado, which supplied the northern Texas Panhandle (Jones and Cline 1940:33, 36, 38; 40, 43, 47, 49, 51, 59; Hendrix 1941:35, 36; Jones and Richardson 1943:39).

The impact of the cattle boom on Colorado City was tremendous. Stimulated by large amounts of foreign capital and by money from the shipment of cattle raised on ranches throughout the Rolling Plains and West Texas, businesses prospered and the population increased from a handful of residents in 1880 to approximately 5,000 or 6,000 individuals in 1884 (Jones and Cline 1940:59). Merchants such as "Uncle Pete" Snyder, who had built a store on Deep Creek in Scurry County to supply buffalo hunters, moved to Colorado City; and numerous Rolling Plains ranchers either made their permanent homes in the town or visited there frequently. Among those individuals were J. B. Slaughter, W. V. Johnson, A. P. Bush, O. J. Wiren, John W. Nunn (Jones and Cline 1940:39; Hendrix 1941:40), J. W. Mooar, Kin Elkins, Clay Mann, Pete Scoggin, Boley Brown (Jones and Richardson 1943:38n), and Andy and Francis Long.

Just as the rangeland and ranches on the western Rolling Plains had a significant impact on Colorado City, so also the town affected the growth and development of the region. Ranchers frequently sent their wagons to the town for six months' worth of provisions which were comprised not only of food but also of every kind of material good used in the construction and operation of a ranch (Jones and Cline 1940:28). Indeed, ranch histories are full of references to the goods shipped from Colorado City. Rollie Burns, for example, noted that the wire needed to fence the Square and Compass Ranch was purchased in Colorado City as was the lumber used to make the plank corrals (Holden 1932:127, 128). 
While the free-range era on the Rolling Plains was stimulated initially by the building of railroads, construction of towns, immigration of ranchers, and investment of foreign capital, the boom that resulted could not last. Railroads, towns, people, capital, and growth of herds all put more pressure on the ranges than could be accommodated, and the onset of bad weather in 1885 eventually resulted in the collapse of cattle markets throughout the region.

According to Bentley (1898:8), absentee landowners began to look at their land in the vicinity of the Texas and Pacific Railroad as early as 1882 and to realize that "they could not depend much longer on 'free grass'." By 1884 some fence had been installed on the Llano Ranch south of present-day Post and on the Square and Compass on the western portion of the Double Mountain Fork of the Brazos River (Holden 1932:112, 128). But such installations only aggravated the free-rangers, and following a protracted drought in 1885-1886, cattle carcasses piled up against the barbed wire as animals attempted to drift south during the blizzard of 1886-1887. Thousands of cattle died, and the ranching business reached a low ebb. Colorado City became severely depressed as cattlemen went bankrupt, and businesses closed as the number of cattle shipped on the Texas and Pacific decreased.

While better weather during the early 1890s resulted in higher prices for cattle, both Colorado City merchants and Rolling Plains merchants were dealt blows as the decade continued. First, railroads continued to extend lines throughout West Texas, and the towns that sprang up were in direct competition with Colorado City. In 1887, the Fort Worth and Denver Railroad reached the Amarillo townsite which subsequently appropriated a market covering most of the Panhandle. The Gulf, Colorado and Santa Fe then reached San Angelo in 1888, and that community absconded with most of Colorado City's southern market. The Roscoe, Snyder and Pacific from Roscoe in Nolan County to Fluvanna in Scurry County made further incursions after 1898 as did the Gulf, Colorado and Santa Fe which extended a line to Sterling City to the south (Jones and Richardson 1943:57).

The greatest challenge to Colorado City as the primary supplier of goods to the western Rolling Plains occurred in 1910-1911 when the Santa Fe Railroad completed a track from Coleman to Lubbock. Promoters platted two new towns--Justiceburg and Burnham--that, with Snyder to the southeast and the new city of Post to the northwest, became the trade centers for much of northern Scurry and Garza counties and western Kent County.

Just as Colorado City merchants were negatively affected by the narrowing of their trade territory which occurred as railroad lines were extended, so also ranchers were affected by the flood of immigrants arriving on those lines and by the passage of legislation encouraging settlement by those immigrants. To cattlemen, the most pernicious legislation was the Four-Section Act of 1895 which stimulated the interest of immigrant settlers in the western Rolling Plains and eventually resulted in the diversification of the area's economy.

The Four-Section Act enabled individuals to purchase one section from the State for use as a homestead and to purchase an additional three sections for grazing purposes. The applicant was required to live on his homestead section, to make permanent improvements to it, and then to file proof of occupancy after three years. Response to the Act took two different forms. In the first case, ranchers induced their employees to file on four 
sections each. Each hand was then allowed to run his own stock with his employer's herd but was required to obtain the employer's approval before selling the land. In the second case, immigrants from outside the area arrived with the intention of homesteading, constructing permanent improvements, and raising families. For the most part, the cowhands participated only in the cattle industry, while the new residents were agriculturalists who emphasized crop cultivation, sometimes in combination with limited stock raising.

Competition between the two groups was fierce at first, and land rushes occurred in the western Rolling Plains around the turn of the century. New homesteaders who were successful in filing on four sections found their initial crop-raising activities aided by good rainfall and excellent crops between 1900 and 1906 (Jones and Richardson 1943:61). While some of the area continued to be more suited to cattle than to crops, there were sufficient areas in southwestern Kent County, near Post, and in the upper reaches of the Double Mountain Fork of the Brazos River to justify optimism about the cotton- and graingrowing capacity of the western Rolling Plains. Small farming communities such as Polar grew up on the uplands near the confluence of the North Fork of the Double Mountain Fork and the Double Mountain Fork (Ford 1988). Cotton, corn, red-top cane, and goose-neck maize were frequently grown crops in Scurry County, while to the north in Garza County, C. W. Post purchased portions of the Curry Comb, U Lazy S, and OS ranches that he then colonized (Mason 1956) with farmers who used dryland farming techniques to raise large crops of cotton.

In the years that followed the closing of the range and the immigration of homesteaders, settlers who raised cotton and other crops crowded cattlemen who raised livestock into the breaks of the Caprock Escarpment and of the Brazos as "every acre that might by any stretch of the imagination be termed tillable went under the plow" (Hendrix 1941:29). During the late 1920s and throughout the 1930s, however, collapsing farm markets made it clear that reliance on a single crop such as cotton could have the same devastating effect as reliance on livestock alone. While ranchers in some areas were forced to engage primarily in livestock raising because their land could not be cultivated, farmers and ranchers in other areas were forced to diversify. By World War II, monoculture had disappeared from most of the western Rolling Plains, replaced by an economy that successfully combined livestock production with raising of cotton and grains. 



\section{CHAPTER 4}

\section{SITE INVESTIGATIONS}

by Martha Doty Freeman and Douglas K. Boyd

This chapter describes the work at five historic sites; three are first-priority sites which were intensively investigated, and two are second-priority sites which received only minimal investigation. The work at the first-priority sites consisted of archeological testing at two sites (41GR474 and 41KT42) and archival/informant research for these two and one other site (41GR250). The work at the second-priority sites consisted of revisiting and reassessing one site recorded during Phase I (41GR528) and initial recording of one site (41KT150) after its location was discovered through informant research.

\section{First-priority Sites}

41GR250

SITE SETTING

Site 4 IGR250 is situated on an eroded upland ridge in the wide valley of the upper reservoir. The historic component at the site is located $1.2 \mathrm{~km}$ northeast of the community of Justiceburg on the west side of Salt Branch ca. $250 \mathrm{~m}$ north of FM 2458 . It is on the southeastern end of a northeast-southwest ridge $100 \mathrm{~m}$ northwest of Salt Branch. Site elevation is 2240-2260 $\mathrm{ft} \mathrm{msl}$.

\section{WORK ACCOMPLISHED}

This site was recorded in 1987 as a prehistoric campsite/lithic procurement area with an historic component. The historic component consisted of a $10 \times 16-f t$ depression with an associated artifact scatter. The site was identified as the original location of the Forrest Tuffing home. A house located at this site was moved ca. 0.25 mile to the east where it still stands; it is recorded as part of the historic component at $41 G R 13$. The 1987 assessment indicated that 41GR250 warranted further work (Boyd et al. 1989).

At the time the site was originally recorded, little was known about the historic component. The archeological remains, i.e., features and artifact deposits, appeared to be intact, but the duration and significance of the occupation was not revealed in the preliminary historical research. The 1988 investigations consisted only of site-specific archival and informant research. No additional fieldwork was conducted, and the prehistoric component was not investigated.

\section{SITE HISTORY}

According to investigations conducted in 1987 (Bryan et al. 1989:585), 41GR250 was the original location of the Forrest Tuffing home. Detailed information about the history of 
the tract on which the site is located was not provided in 1987 because initial work with the Garza County deed records failed to find conveyances predating 1912 when the property was sold to Arthur E. Tuffing, and no county tax records exist in Post which predate 1916.

A reexamination of the records in 1988 resulted in the discovery of a relevant deed filed some 20 years after the conveyance of the property occurred. This discovery made it possible to complete the legal record and to confirm that the earliest date of occupation at the site probably was the 1920s, as suggested in Bryan et al. (1989:585).

According to the Garza County deed records, Section 21, Block 6, on which 41 GR250 is located, remained railroad property in the possession of Thomas R. White, Jr., of Union County, New Jersey, until February 25, 1903, when White, acting through his agent Ira H. Evans, sold the section to H. G. Spooner of Palmyra, Ohio, near Akron (Garza County Deed Record 7:298-300). Spooner died in Palmyra on September 14, 1906, and his will was admitted to probate on October 15 (Garza County Deed Record 24:15-19).

Spooner left one heir, a daughter named Lora Hanna Jones who was married to David F. Jones (Garza County Deed Record 24:15-19). The Joneses, also of Palmyra, held the acreage until November 18, 1912. At that point, they sold it to Arthur E. Tuffing, previously from the Akron, Ohio, area whose family home appears to have been located on Section 10, Block 6, in Garza County (Garza County Deed Record 14:548-549; Didway 1973:28; Bryan et al. 1989:580).

A Tuffing son, Forrest, received Section 21 from his parents in the late 1920s, and he moved a building from the abandoned Burnham townsite to 41GR250 (Nance 1988). He and his wife, Winnie Ramsay Tuffing, lived at the site until the early 1930s when Forrest, with the assistance of Shorty Milton and Jim Bright, moved the house once again to a new location (41GR13) (Nance 1988). Winnie Tuffing continued to occupy the house after the death of her husband on January 25, 1934 (Nance 1988).

41GR474

\section{SITE SETTING}

Site 41GR474 is situated on an erosional remnant bedrock terrace in the upper portion of the reservoir $1.4 \mathrm{~km}$ east-southeast of the U.S. Highway 84 bridge across the Double Mountain Fork. The site is located on the south side of the river within a prominent meander bend. The erosional remnant forms a northeast-projecting ridge which varies from a few meters to $15 \mathrm{~m}$ in height above the river. Sandstone bedrock is exposed around the margins of the landform and sporadically within the interior. Alluvial and/or eolian sediments cap most of the erosional remnant, and substantial eolian sand accumulations cover most of the northeastern end of the landform. Site elevation is 2220-2260 $\mathrm{ft} \mathrm{msl}$.

\section{WORK ACCOMPLISHED}

This site was recorded in 1987 as a Late Prehistoric open campsite with a multicomponent historical occupation. Historic remains noted were a dugout built and occupied prior to 1900 and a post-1900 housesite complex with related structures and features. Historical 
research indicated that both occupations were by Jeff Justice, who promoted the town of Justiceburg. Archeologically, materials relating to both occupations were considered to be intact. The 1987 assessment indicated that the site warranted further work (Boyd et al. 1989).

The 1988 investigations consisted of site-specific archival and informant research and archeological investigation of the historic occupations. The archeological work consisted of a surface inspection and mapping of the surface structures, features, and artifact concentrations (Fig. 4). A few diagnostic artifacts were surface collected from near the dugout and from the house area. Archeological testing focused on the earlier historic remains. Testing of the dugout entailed the excavation of two $1 \times 1-m$ test units and a $0.5 \times 3.0-\mathrm{m}$ trench in the dugout depression. The excavations were oriented roughly northsouth in a row across the depression.

\section{SITE EXTENT AND DEPTH}

The site covers an area of $600 \mathrm{~m}$ northeast-southwest by $400 \mathrm{~m}$ northwest-southeast, defined mainly by the extent of the landform within the river meander. The prehistoric component covers the entire site area, while the historic component is confined to the north-central portion. The historic archeological remains are surficial except for subsurface structures and features. The earliest historic occupation is represented by the dugout depression which is partially filled with trash from later occupations. The surface scatter around the dugout appears to be a mixture of early and late artifacts. The early portion of the historic component is confined to a $20 \times 20-\mathrm{m}$ area, and the dugout is less than $1 \mathrm{~m}$ deep. The later historic remains consist of a complex of structures and features over a ca. 150×250-m area, including the dugout.

\section{STRUCTURES AND FEATURES}

Investigation of the later house complex consisted of mapping the area and surface collection of some diagnostic artifacts. Surface structures and features were not recorded in detail. The most obvious feature is a standing metal windmill tower. The windmill mechanism has fallen or been removed and is scattered on the ground below. The tower is planted firmly into a concrete foundation, and there is a concrete-bottom metal water tank adjacent to the windmill. Nearby is the structural foundation and brick scatter associated with the main house. Other concrete foundations indicate that other buildings were associated. A network of barbed wire fences encloses the house area, and a large wooden railroad-tie corral is located to the southwest. The fences and corral are still standing in places but are in poor condition. A large fenced area west of the house has been recently bladed. About $120 \mathrm{~m}$ northeast of the windmill tower is the dugout depression.

Archeological testing of the dugout revealed that the depression was used as a trash dump. Figure 5 shows the cross section of the dugout. The dugout floor was encountered ca. $1 \mathrm{~m}$ below the surface, but no walls were found. It appears that after abandonment the dugout filled partially with sediment and a layer of rocks slumped into the depression. The structure may have been a half-dugout with upper walls made of stacked rocks, or there may have been a rock chimney which collapsed. After the rocks collapsed into the depression, the walls continued to erode and more sediment accumulated. By the time the occupants of the post-1900 housesite began dumping trash there, the dugout was only a 


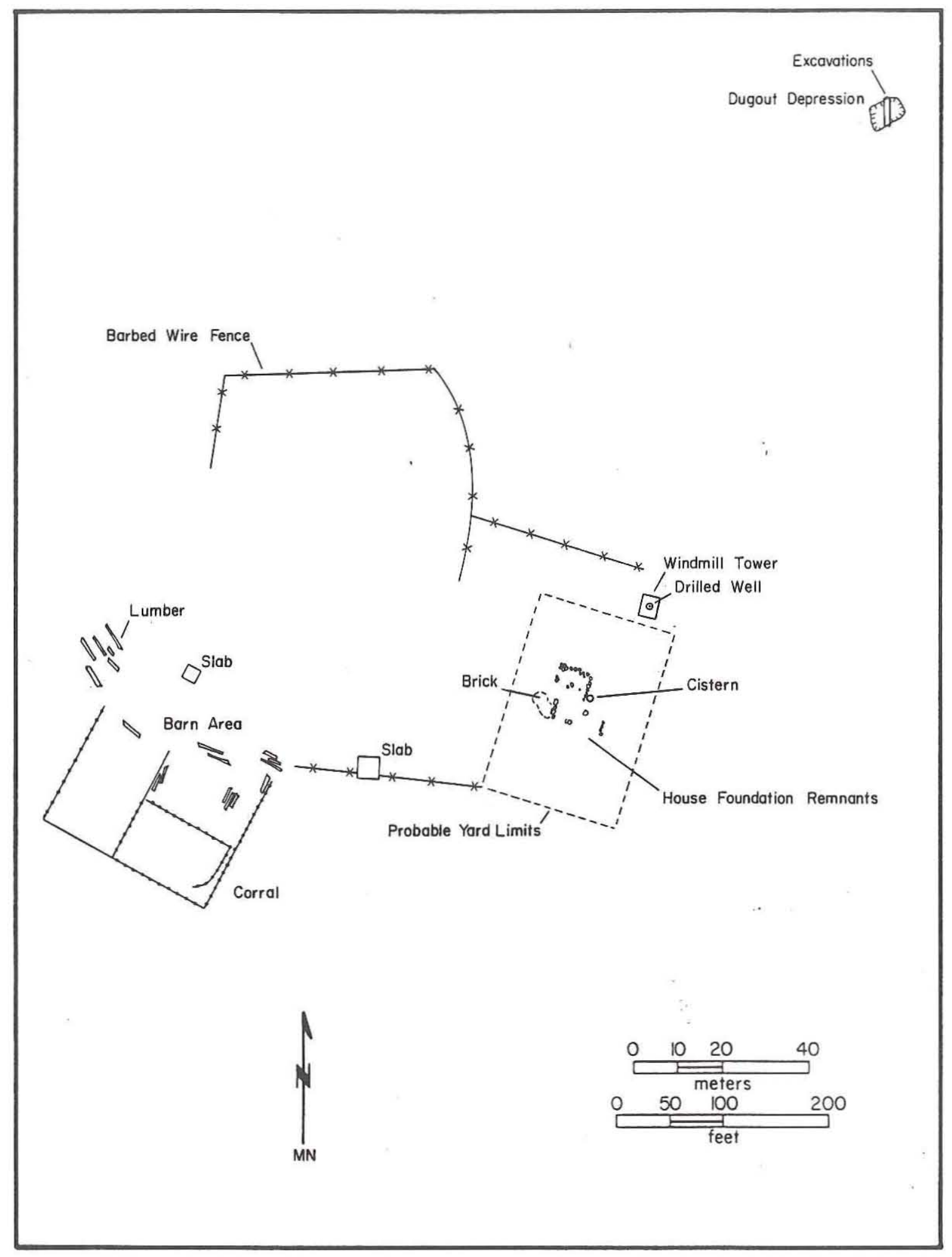

Figure 4. Map of historic component of $41 \mathrm{GR} 474$. 


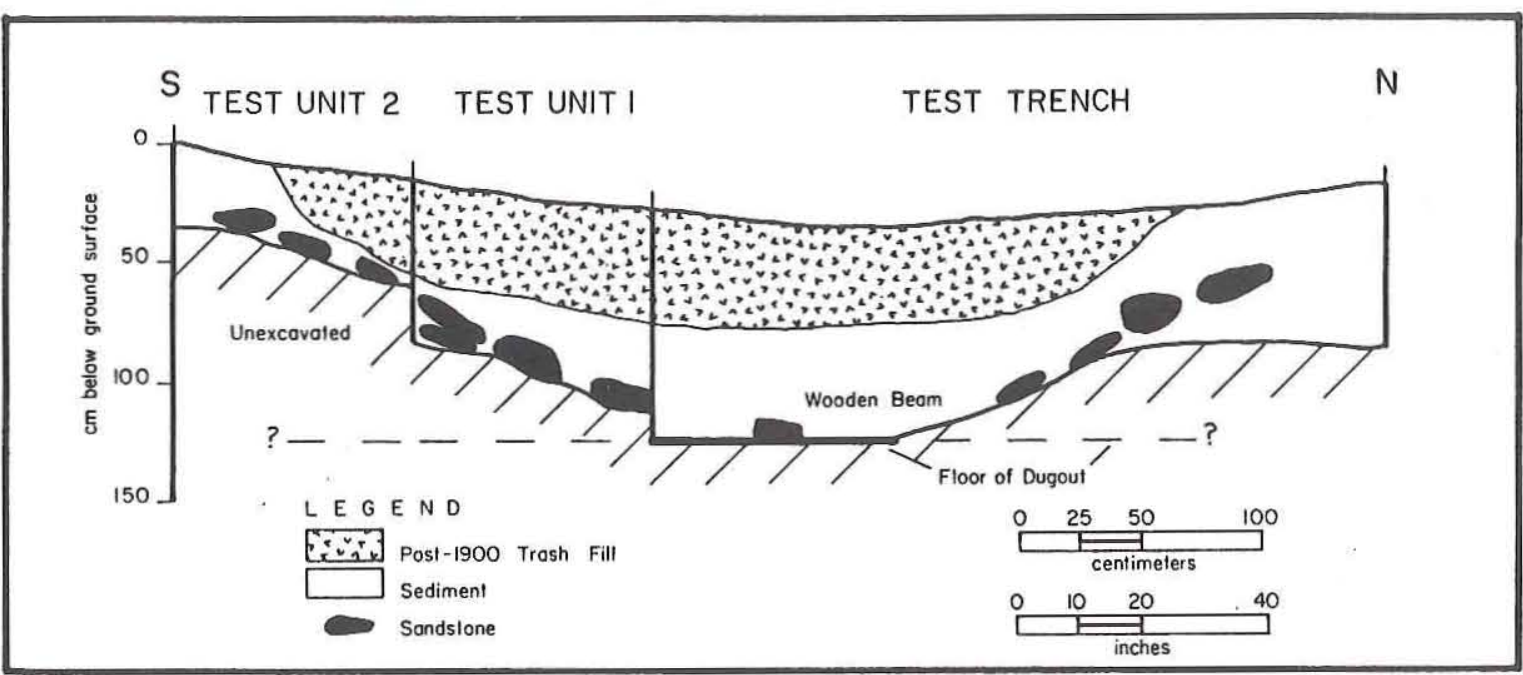

Figure 5. Generalized profile of the dugout excavation, 41 GR474.

basin-shaped depression. More sediment accumulated in the depression during and after deposition of the trash fill.

The excavations revealed only a small area of the floor of the dugout, but artifacts found on the hard-packed floor indicate that the remains are intact. The excavations also exposed a 50-cm segment of a wooden beam lying directly on the floor. The beam is rectangular in cross section and may be either cut lumber or a hand-hewn log. It could be a roof or roof support beam, and its presence on the floor may indicate that the roof collapsed prior to collapse of the rock walls.

\section{MATERIALS RECOVERED}

Cultural materials recovered are associated with both the pre-1900 and the post-1900 occupations and include surface and excavated artifacts. Surface collections are from two areas, the house complex (artifacts are associated with the late occupation) and the vicinity of the dugout (artifacts may be associated with either occupation). The materials recovered in excavations are associated with both occupations. The cultural materials from the upper portion of the excavations include a wide range of items that were discarded into the dugout depression after it had been abandoned for some time (see Fig. 5). All of these materials are associated with the post-1900 occupation. Artifacts recovered from below the trash layer are associated with occupation of the dugout. All of these items were found lying on or just above the floor.

The cultural materials recovered from 41 GR474 consist of 12 artifacts associated with the early occupation, 440 artifacts associated with the later occupations, and 5 artifacts representing a mixed assemblage. These are described and discussed in the Appendix. 


\section{SITE HISTORY}

Historic research conducted in 1987 concerning 41 GR474 revealed that the site was located in the south half of Section 20, Block 6, a 320-acre tract leased by the Lexington Ranch Company of Nolan County from the General Land Office from 1888 to ca. 1896 and homesteaded by Jeff Justice between ca. December 1899 and 1903 . Justice is believed to have constructed and occupied a dugout at the site in order to fulfill the State's residency requirements. Soon after 1900, he constructed and moved into a frame house which was also located on the site.

Research conducted in 1988 was directed toward gathering more information about the dugout and house sites, the years of their occupation, the history of their use, and their appearance before collapse and/or destruction. Members of the Justice family were interviewed, and limited archival research was performed.

Very little additional information was gathered about the dugout component of the site. No former occupants of the site, even those whose knowledge of the area dated back to World War I, were aware of the dugout. As a result, even informants who had occupied dugouts themselves elsewhere in the project area and were familiar with the house type did not associate such a structure with the Jeff Justice property (Justice 1988; Smith 1988). This lack of knowledge about the Justice dugout suggests not only that this occupation must have been very brief but also that the dugout may not have been used for another purpose (such as storage) after its abandonment. Rather, it may have collapsed and filled in by World War I, becoming a visually unprepossessing part of the overall site.

Information gathered from informants and derived from an historic photograph revealed that the Jeff Justice headquarters was a complex, well-developed site which included the house, cistern, well, outhouse, smokehouse, pens, and barn. The house, a frame structure with a cedar shingle roof, was the primary visual feature of the site. Built with materials hauled from Colorado City, the raised structure faced south and was an unusual design, having a large, hexagonal, projecting bay surrounded by a covered porch. A central hall which ran north from the projecting bay was flanked by a living room with a fireplace and kitchen on the west and by two bedrooms and a lean-to on the east. In between the northernmost bedroom and the lean-to was a washroom with a mirror and basin, an unusual feature in a turn-of-the-century West Texas residence. Entrances to the house were off the porch into the living room and front bedroom. The projecting bay, which had large windows on all walls for ventilation, served as Jeff Justice's bedroom and was the dominant feature of the house (Fig. 6) (Justice 1988, 1989).

The exterior foundation of the house was stacked stones; interior footings may have been cedar posts. Interior and exterior walls were wood; interior floors were pine. The exterior walls were painted white with trim which was a different, but as yet unidentified, color. The shingled roof drained to an eavestroughing system which emptied, in turn, into a dug, plastered cistern located at the rear of the house northwest of the lean-to (Justice 1988).

A fence surrounded the house, enclosing a space that included a yard, the house, and the cistern. Outside the fence on the south was a hitching rack. East of the house were an outhouse and a smokehouse, the latter being a board-and-batten structure measuring ca. $10 \times 12 \mathrm{ft}$ on a mortared rock foundation and having a dirt floor. A drilled well was located north of the house and provided highly mineralized water which local people believed was good for their health (Justice 1988). 


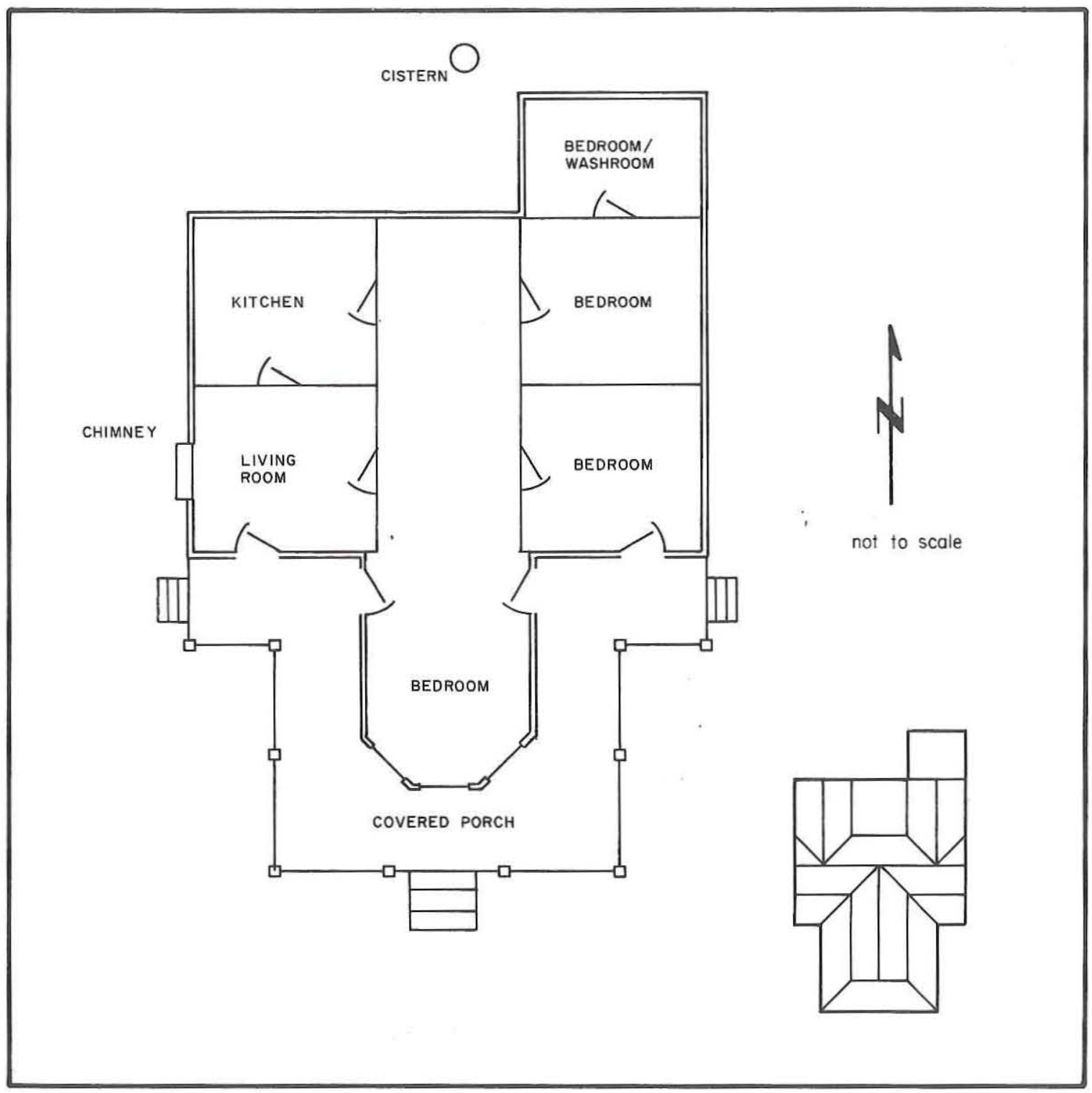

Figure 6. Floor plan and roof plan of the Jeff Justice House at site 41 GR474.

West of the house were four divided lots or pens, a working chute, and a long barn. A closed-in area at the east end of the barn served as a saddle house, and a similar space on the west end served as a feed house. The two rooms provided storage space for horse equipment and saddles, harness for the farming teams, and grain and other materials used to feed animals. Livestock included goats, Hereford cattle, and mules which drew Justice's buggy. In later years, Justice built a garage with a concrete slab between the house and barn for an automobile which a descendant recalls was the fifth car registered in Garza County (Justice 1988, 1989).

The Justice family occupied the house at 41GR474 until about 1920 when Mr. Justice moved to Fort Worth and Mrs. Justice moved to Post. The family then rented the structure 
out, and it was occupied by a number of local residents including Cecil Smith, the Bungers, members of the Justice family, and Liz and Wilson Connell. In the 1960s, after Mrs. Justice died, Raymond Key, Add Jones, and Oliver Curtis helped demolish the house, parts of which were used to construct another ranch headquarters belonging to Justice descendants west of Justiceburg (Justice 1988).

$41 \mathrm{KT} 42$

\section{SITE SETTING}

Site 41KT42 is situated on an upper alluvial terrace near the mouth of Grape Creek ca. $0.5 \mathrm{~km}$ southeast of its confluence with the Double Mountain Fork. The site is on the east side of the creek at the base of the canyon valley wall and overlooks the broad valley at the mouth of Grape Creek. The terrace slopes eastward toward Grape Creek, and the site occupies a large area between the valley wall and the creek. The site elevation ranges from 2140 to $2160 \mathrm{ft} \mathrm{msl}$. Severe erosion has formed deep gullies across the terrace where run-off from the canyon wall runs west into the creek. A deep, narrow gully is located at southern end of the site, and a wide gully is located at the northern end. Vegetation is moderate to heavy except where erosion is active. Some vegetation clearing may have disturbed the site, and the area has been a popular picnic spot for local residents.

WORK ACCOMPLISHED

This site was recorded in 1987 as a prehistoric open campsite with an historic component consisting of a rock foundation and fireplace and an associated artifact scatter. Archival research suggested that the historic structure might have been a cattle company line camp, possibly constructed as early as 1882, and one of the two longest occupied historic sites in the project area. The 1987 assessment indicated that the historic component warranted further work (Boyd et al. 1989).

The 1988 archeological investigations consisted of a surface inspection of the structure and surrounding area, site mapping (Fig. 7) and detailed mapping of the structure, and excavation of four $1 \times 1-m$ test units. The test units were contiguous from east to west across the southern end of the structure, exposing the sandstone slab foundation at 0-20 cm. Part of Test Unit 1 was excavated to $40 \mathrm{~cm}$ to expose the base of the foundation. The test units were oriented with the structure, ca. $10^{\circ}$ west of north. Inspection of the site revealed three features, two rock concentrations which may be associated structures and a possible activity area near the house. Surface artifacts were mapped, but no collections were made. Archival research and informant interviews provided limited data on the structure. No work was conducted on the prehistoric component.

\section{SITE EXTENT AND DEPTH}

The test excavations revealed that the structural foundation is higher than the surrounding ground surface and probably sits directly on top of the surface of the terrace. Associated artifacts occur on the surface over a wide area, defining the site extent. The house foundation lies roughly in the center of the site area which covers ca. 130x130-m 
Feature I

on 890900 House Foundation

on 0

0000

$000000^{108}$

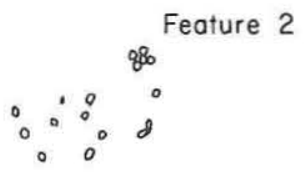

Feature 3
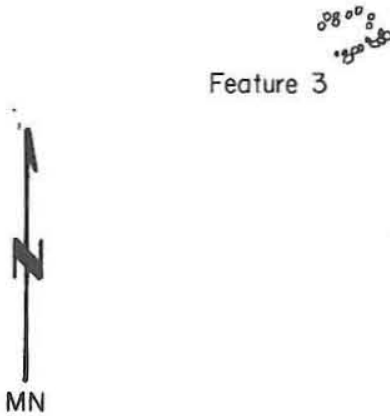

Figure 7. Map of historic site area, $41 \mathrm{KT} 42$.

(Fig. 8). The site is bordered on the north and south by erosional gullies, on the east by the valley wall, and on the west by the extent of surface artifacts. All artifacts are surficial or shallowly buried.

\section{STRUCTURES AND FEATURES}

The house foundation dominates the site, but two rock concentrations (Features 2 and 3) were also recorded and may represent smaller structures. A small cluster of rocks (Feature 1) north of the house structure may represent an outside activity area.

The house structure is represented by a rectangular foundation of dry-laid sandstone slabs oriented north-south with an intact firebox at the north end (Fig. 9). The rock chimney has collapsed onto the foundation, leaving a jumble of sandstone slabs mainly to the northwest, west, and southwest of the firebox. A large agarita bush is growing in the center of the structure, and tall grass is growing over most of the structure. The rectangular foundation measures ca. $6.2 \times 4.4 \mathrm{~m}$ (ca. $20 \times 14 \mathrm{ft}$ ) with the long axis oriented ca. $13^{\circ}$ west of north. The firebox is centered along the north wall and measures ca. $2.3 \mathrm{~m}(7 \mathrm{ft} 3$ inches) wide by $46 \mathrm{~cm}$ (1 ft 6 inches) deep (exterior dimensions). It stands $1.2 \mathrm{~m}(4 \mathrm{ft})$ tall at the highest point. The sandstone slabs on the interior of the firebox are reddened from heating. There is no evidence of windows or a doorway, but two large wooden beam fragments lying in the rock jumble may be roof or wall remnants. Excavation of the four 


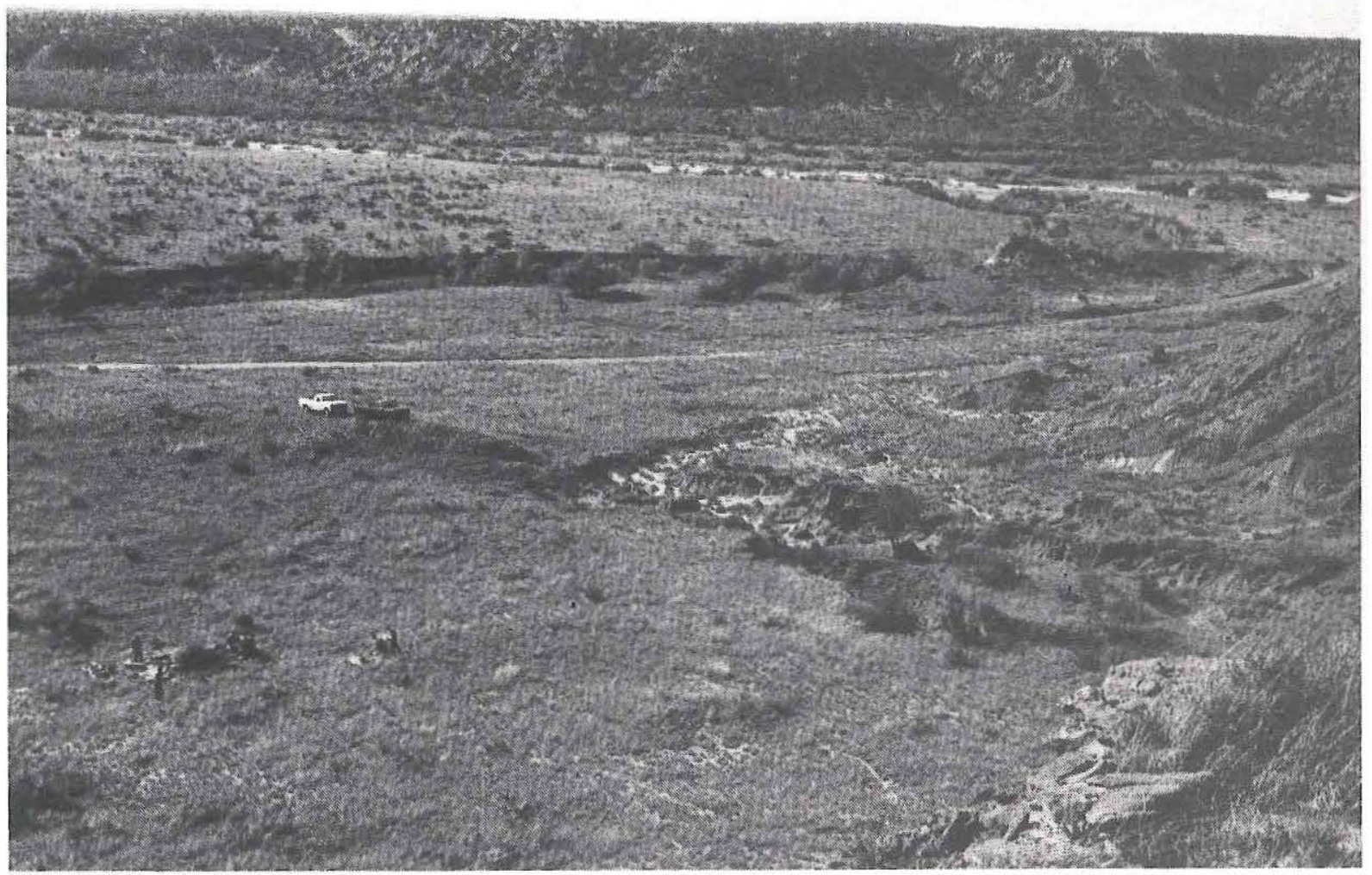

Figure 8. General view of site 41KT42. View is to the west-northwest from the talus slope of the east Grape Creek valley wall. House foundation is at lower left.

test units along the south wall of the structure (see Fig. 9) revealed a solid course of unworked sandstone slabs forming the foundation.

Feature 1 is a small circular cluster of fist-sized sandstone fragments. The center of the 1-m-diameter cluster is located $3 \mathrm{~m}$ due north of the center of the firebox. The function of the cluster is unknown, but it may represent an outside activity area.

Feature 2 is a concentration of sandstone slabs within a $5 \times 5-\mathrm{m}$ area. The concentration consists of smaller piles of rocks and scattered individual rocks. The location of the feature, isolated in a flat area, suggests it is not natural, but there are no associated surface artifacts and no recognizable patterning, possibly due to the vegetation growth which limits ground visibility. The cluster is ca. $30 \mathrm{~m}$ southeast of the house site and may be the remains of an associated structure.

Feature 3 is a series of crude stone alignments within a $3 \times 3-m$ area. Two sandstone slab alignments form parallel rows ca. $1 \mathrm{~m}$ apart. Each row is ca. $1 \mathrm{~m}$ wide and $3 \mathrm{~m} \mathrm{long.}$ The two rows are oriented northeast-southwest, and a partially buried cluster of rocks at the northeast end may be a portion of a third row of rocks. The feature is ca. $50 \mathrm{~m}$ southeast of the house structure adjacent to the base of the east valley wall of Grape Creek. Talus rocks are found nearby, but the patterned nature of these rocks is suggestive of a structure. The feature may have been a foundation for a small wood-frame structure. 


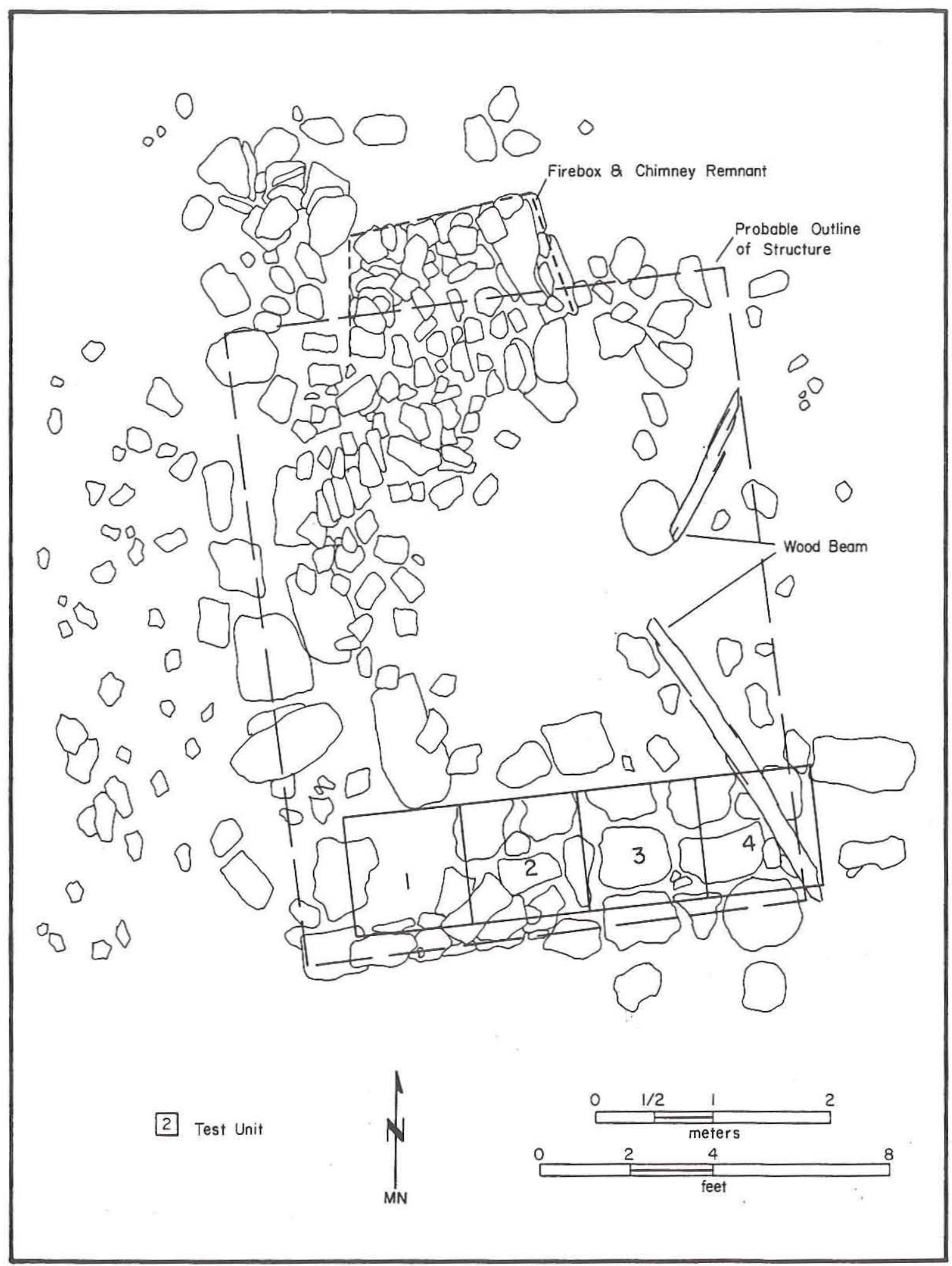

Figure 9. Map of house structure, 41KT42. 
MATERIALS RECOVERED

Sixty artifacts were recovered from the excavations at the house structure. These 1tems represent debris lost or discarded in and around the house. No surface collections were made, and no formal trash dump area was located. The materials recovered are described and discussed in the Appendix.

\section{SITE HISTORY}

Historical research conducted in 1987 revealed that 41 KT42 was located in Section 56, Block 5, Kent County, on 640 acres owned by H. T. "Tuck" Cornelius. Cornelius had operated a trading post on Deep Creek in present-day Scurry County from 1876 to 1878 when he sold out to Pete Snyder (Anderson 1984:53). Sometime between 1878 and 1882 he went into business with buffalo hunter-turned-rancher J. Wright Mooar and purchased Section 56 from the State of Texas.

Cornelius owned the property on which 41KT42 was located between 1882 and December 14, 1886, when he sold it to Nolan County rancher A. J. Long who used the land for grazing. Subsequent owners included W. E. Connell, John Scharbauer, and E. W. Clark, and later Connell's heirs. During the period from 1882 to the present day, the property appears to have been used exclusively for ranching purposes (Bryan et al. 1989:633-634).

According to informants interviewed in 1987 and 1988, 41KT42 was the location of a line camp which was used by cowboy employees of the Longs and Connells. Informants differ in their recollections of the appearance of the structure at the site, with one individual remembering a board-and-batten building that was a ruin by World War I (Ford 1988) and another remembering a log building that was largely intact until recent years when it was vandalized (Williams 1988). According to Williams, the line camp structure was used by cowboys 0. B. Kelly, Ed Scott, and Oliver Curtis. The west facade was the location of the entrance where a hitching post was located. Corrals were situated to the east (Williams 1988).

While no historic documents were located pertaining to the pre-1880s use of the site, the association of the property with a former trader during the buffalo hunting period (H. T. "Tuck" Cornelius) may be a significant one. Cornelius was living in the ScurryGarza county areas by 1876 , and Section 56 is one of only three sections along Grape Creek which he purchased from the State, an action that may indicate he was familiar with the property before 1880. The presence of an historic Indian camp in the vicinity of $41 \mathrm{KT} 42$ when George Kindred Elkins visited the area in the early 1880s (Ford 1988) is further evidence of the desirability of the area of the confluence of Grape Creek with the Double Mountain Fork of the Brazos River. The presence of cultural faunal localities and of Late Prehistoric or protohistoric aboriginal campsites in the vicinity of $41 \mathrm{KT} 42$ (41KT51, 41KT52, 41KT53, 41GR323, 41GR484, and the protohistoric/prehistoric component of 41KT42) in turn raises significant questions about the abundance of wildlife along Grape Creek, the history of exploitation of that resource by historic Indian populations and possibly buffalo hunters, and the continuity of use after the economic base of the area changed to 1 ivestock in the 1880 s. 
Second-priority Sites

41GR528

SITE SETTING

Site 41 GR528 is situated on a gravel-capped erosional remnant ridge on the west side of Sand Creek overlooking a small west-east drainage which runs into the creek. The site is $0.7 \mathrm{~km}$ north of the U.S. Highway 84 bridge over Sand Creek. The site occupies the prominent hilltop and extends south onto the eroded bedrock/alluvial terrace below the hill. Site elevation is $2250-2260 \mathrm{ft} \mathrm{msl}$.

\section{WORK ACCOMPLISHED}

This site was recorded in 1987 as a prehistoric open campsite with an historic component. The historic component consisted of an isolated 1878 grave on top of the ridge and a scatter of historic artifacts at the southern base of the ridge. The site was first discovered by Emmett Shedd of Post, Texas. Preliminary notes were made in 1987 concerning Shedd's collection of artifacts from the site. Historic research indicated that the grave and artifact scatter were probably related and might be associated with the last of the buffalo hunting activities in the Southern Plains. The 1987 assessment indicated that the site warranted further work but noted that the artifact scatter appeared disturbed and lacked associated features (Boyd et al. 1989).

The 1988 archeological investigations consisted of a site revisit and reevaluation, surface collection of diagnostic artifacts, detailed documentation of the headstone, and preliminary documentation of a local collector's artifacts from the site. A surface inspection confirmed the original assessment that the artifact scatter is located in an eroded area and lacks contextual integrity. The surface artifact scatter is confined to a few square meters on thin sand and bedrock. A small surface collection of diagnostic artifacts was made. To document the headstone, a visquene tracing of the stone and epitaph was made. A collection of artifacts from the site owned by Virgil Streety of Snyder, Texas, was reviewed and preliminary notes made.

\section{MATERIALS COLLECTED}

Ten specimens collected from the small artifact scatter are described and discussed in the appendix to this report. These materials, along with the artifacts noted in the Shedd and Streety collections, are suggestive of buffalo hunter activities; firearms reloading is well represented.

\section{SITE HISTORY}

Site 4 IGR528 is located in Section 13, Block 6, a tract of 640 acres patented to the Houston and Great Northern Railway Company on December 9, 1873, and leased for grazing to the firm of J. W. Mooar Brothers Cornelius and Sloan from June 14, 1882, to June 13, 1887 
(Texas. General Land Office 1873a; Garza County Deed Record 3:29-32). On March 16, 1901, the section was sold to Jeff D. Justice whose ranch headquarters was located on the southern portion of Section 20, Block 6 (Garza County Deed Record 7:561-565), and Justice and his heirs used the property for grazing and gravel mining from Sand Creek until World War II.

Research conducted in 1988-1989 was directed toward identifying the function(s) of 41GR528, creating an historic context for establishing the identity and assessing the significance of the camp component of the site, identifying A. W. McCormick, the individual buried at the site, and determining whether or not his grave was associated with the camp component. Archival work, completion of an historic context for buffalo hunting on the Rolling Plains during the 1870s, interviews with local residents, and viewing of the Streety collection suggested that the site included at least one feature which has disappeared due to erosion during the past 50 years. According to two informants (Justice 1988; Shedd 1988), this feature consisted of a dugout located in the bluff immediately south of the McCormick burial. Based on a story which another local resident had told them, the informants assumed that the dugout was occupied by cowboys, of whom $A$. W. McCormick was one.

Other information pertaining to the site and to the possible identity of McCormick was the recollection of OS cowboy Ed Scott that McCormick was a cowboy who had died in camp of dysentery. However, Scott also had obtained his information second hand, and efforts to identify McCormick who was born in St. Louis by using the Missouri federal census records proved unsatisfactory since the voluminous $1870 \mathrm{St}$. Louis census has not yet been indexed. Examination of earlier censuses provided unsatisfactory results since the Alexander $W$. McCormack [sic] identified in the 1850 census would have been 61 years of age in 1878, and the Alexander McCormick identified in the 1860 census would have been 25 years of age. Thus, neither individual could have been the 36-year-old buried at 41GR528.

It is possible that the site could be associated with ranching activities on the Rolling Plains, for rancher Smokey Brown was located on Alamo River (Sand Creek east of present-day Post) immediately north of the project area ca. 1877, John and Finis Lindsey ranched west of the project area on the Double Mountain Fork sometime before 1880, W. A. Johnson and the Nunn brothers located in northeastern Scurry County in 1877-1878, and George Elkins established his headquarters just east of the project area in Kent County in 1877 (see Fig. 3 and Table 7). It would not have been unusual for any one of those ranchers to have had line camps on land that was not only still owned by the State and the railroads in 1878 but also was unfenced open range.

On the other hand, it is clear that buffalo hunters were active in the area until the winter of 1879 and that hunting outfits were present in the area of 41GR528. It would not have been unusual for hunters to have constructed a dugout, one of the property types known to have been associated with such sites (see Tables 3 and 4 ), and the munitions collected from the site are typical of those used by buffalo hunters. Indeed, the existence of large-caliber cartridges, primers, slugs, and sprue all point to specialized hunting activities involving big-game animals. 
$41 \mathrm{KT} 150$

\section{SITE SETTING}

Site $41 \mathrm{KT} 150$ is situated on the upland margin on the east side of Grape Creek ca. $6 \mathrm{~km}$ upstream from its confluence with the Double Mountain Fork. The site covers an area of ca. $20 \times 20-m$ on the south-sloping upland edge. It is at an elevation of $2260 \mathrm{ft} \mathrm{msl} \mathrm{ca} .35 \mathrm{~m}$ north of and 10-15 m above a small spring-fed drainage which flows west into Grape Creek. The site is $130 \mathrm{~m}$ east of the concrete crossing at the upper end of Grape Creek. An oil well pad is located ca. $80 \mathrm{~m}$ west of the site, and the east-west road to the well pad is ca. $20 \mathrm{~m}$ north of the site.

\section{INVESTIGATIONS}

This site was recorded during the 1988 investigations. The location of this historic dugout adjacent to the project area was discovered following an interview with Mrs. Mary Alice Headstream of Abilene, Texas, who confirmed data provided by other informants. The location was visited, and a dugout depression and a sparse scatter of surface artifacts were recorded. No collections were made. The site is ca. $50 \mathrm{~m}$ outside the project area.

The dugout depression opens downslope to the south (presumably the entrance). The north end of the depression is marked by a pile of sandstone rocks, possible chimney fall, covered by dense vegetation. The few artifacts noted in and around the depression include a metal washtub, refined earthenware plate fragments, and a metal smoke/rain deflector off a stovepipe.

\section{SITE HISTORY}

Site $41 \mathrm{KT} 150$ is located in Section 59, Block 5, a tract of approximately 640 acres patented to the Houston and Great Northern Railroad Company on December 27, 1873 (Texas. General Land Office 1873b). On November 20, 1880, the land was conveyed to the New York and Texas Land Company, Ltd., which leased Section 59 and 136 other sections in Blocks 4, 5 , and 6 to the firm of J.W. Mooar Brothers Cornelius and Sloan of Colorado City (Texas. General Land Office 1873a). The firm, which was comprised of J. Wright and John W. Mooar, W. T. Cornelius, and C. Sloan, paid $\$ 1,753.60$ per year for a lease which ran from June 14, 1882, to June 13, 1887 (Garza County Deed Record $\underline{3}: 29-32$ ).

On April 22, 1887, the New York and Texas Land Company, Ltd. conveyed the property to William Walter Phelps whose heirs sold it to Thomas R. White, Jr. on August 24,1894 (Texas. General Land office 1873c). White, who was a resident of Union County, New Jersey, then sold Sections 57 and 59, Block 5, to A. O. Scarborough for $\$ 3,200.00$ on June 18, 1901 (Garza County Deed Record 7:112-115). Scarborough built his home on Section 57 and probably used Section 59 for grazing until about 1909 when he divided it into two equal halves. Subsequent owners of the south half, on which $41 \mathrm{KT} 150$ is located, included J. S. Lovelady and his wife until ca. 1940 and W. G. Williams and his heirs thereafter (Kent County Tax Assessors Abstract No. 122). 
Informants have identified 41KT150 as having been a dugout occupied by various cowboys employed by the OS Ranch including Ed Scott and W. G. Williams (Ford 1987; Headstream 1988). Occupancy by OS cowboys would suggest that the site dates to the 1890s. However, it may date to an earller period as well since leasing of the property by the firm of J. W. Mooar Brothers Cornelius and Sloan at a time when H. T. Cornelius owned nearby Sections 56, 58 , and $60 \mathrm{might}$ indicate that the site was occupied in the early to mid 1880s by cowboy employees of that firm. 


\title{
OUTLINE OF PROPERTY TYPES AND NATIONAL REGISTER ASSESSMENTS
}

\author{
by Martha Doty Freeman
}

\begin{abstract}
Chapters 2 and 3 present two historic contexts concerning buffalo hunting on the Rolling Plains from 1874 to 1879 and ranching on the western Rolling Plains from 1877 to 1945. The purpose of the historic contexts is to place certain hunting and ranching sites present in the Justiceburg Reservoir project area within the context of the broader historic patterns that created them and to establish the existence and spatial and chronological extent of other comparable cultural properties.

Chapter 5 consists of two sections. The first outlines the property types that are included within each historic context and within the project area. These property types are described, their significance is defined, and the specific requirements for their registration are listed. The second section briefly examines the 12 historic sites recorded in 1987 (Bryan et al. 1989) that can be reassessed using the information presented in the two National Register contexts and in the registration requirements. Assessments of National Register eligibility are then made. No reevaluation has been completed for sites recorded in 1987 that do not pertain to the National Register contexts presented in Chapters 2 and 3 or for which further archival work was not required in 1988.
\end{abstract}

\section{Buffalo Hunting Camps on the Rolling Plains}

Description

The exploitation of buffalo, once one of the most abundant natural resources in North America, spawned a complex and well-organized business system which had major impacts on the economy of the Great and Southern plains areas of the United States. This system was comprised of readily identifiable components. In the Rolling Plains region of Texas, many of the components functioned to transport materials necessary to the hunt into the buffalo range and products resulting from the hunt out of the buffalo range; they included railroads, towns, mercantile establishments, and trading posts. Other components of the hunt, such as the hunting camps and stands, were the locations where the imported goods were used and the buffalo product was harvested.

During the period of commercial buffalo hunting on the Rolling Plains, ca. 1874-1879, hunting camps were numerous. Historical records mention the existence of such camps in most counties drained by the Clear Fork, Salt Fork, and Double Mountain Fork of the Brazos River, including but not limited to present-day Shackelford, Throckmorton, Haskell, Jones, Fisher, Stonewall, Kent, Scurry, Garza, and Borden, as well as counties to the north drained by the Wichita and Pease rivers. Most of these camps appear to have been established by hunters who obtained supplies and set off from Fort Griffin, a major military post and trading center west of the Cross Timbers following the Civil War. As a result, the Rolling Plains camps were distinguished from those located in the Panhandle area which were supplied by mercantile establishments in Kansas, even though the functions of the camps throughout the Southern Plains region were identical. 
Most archeological features present at buffalo hunting camps on the Rolling Plains are directly attributable to the camps' functions as localities for the acquisition and initial processing of the buffalo product. Such features tend to be ephemeral but readily identifiable; they result from the day-to-day events of camp life (cooking, eating, drinking, smoking, etc.), from the mechanics of acquiring the buffalo product (shooting, reloading, skinning, butchering, etc.), and from the processing of the meat and skins (butchering, pegging, curing, smoking, etc.).

Many camps lacked architectural features either because the occupants slept outside without shelter or because the camps moved so frequently in pursuit of the buffalo that construction of permanent or semipermanent housing was not feasible. Camps at which hunters constructed shelter generally were those occupied during the winter or inclement weather, those at which women were present, or those used over a period of time, often in newly opened hunting grounds where the size of the buffalo population justified hunting episodes of some duration. According to observers and occupants, these shelters took three forms. The first of these were dugouts, some having rock fireplaces, which were excavated into banks, often near streams. A second shelter was the hide or pole house, a roughly rectangular structure made of hides and forked sticks set in the ground and sometimes having a fire pit outside but adjacent to the open end. The third and most common form of shelter was the tepee, a structure made of poles and dried buffalo hides, sometimes having a crude rock fireplace and chimney for cooking and heating. Floors were covered with buffalo hides, which also were used for the door.

\section{Significance}

Archeological sites and architectural properties associated with buffalo hunting may be eligible for listing on the National Register of Historic Places under Criterion A because they "are associated with events that have made a significant contribution to the broad patterns of our history"; Criterion B because they "are associated with the lives of persons significant in our past"; Criterion C because they "embody the distinctive characteristics of a type, period, or method of construction . . or represent a significant and distinguishable entity whose components may lack individual distinction"; or Criterion D becuase they "have yielded, or may be likely to yield, archeological information important in - . history" (U.S. Department of the Interior, National Park Service, National Register Division 1982:1)。

Buffalo hunting was one of the most important activities that occurred on the Rolling Plains during the 1870s. The acquisition and marketing of the buffalo product spurred the development of communities such as Dallas, Fort Worth, Denison, and Fort Griffin; brought prosperity to innumerable merchants in those towns and at trading posts such as Rath City in present-day Stonewall County and Snyder's Store in present-day Scurry County; established trade networks that were later used to market agricultural goods such as cattle; and eliminated the primary competitor with cattle and sheep for grass. Indeed, it is questionable whether the initiation of cattle ranching on the Rolling Plains could have occurred without the systematic destruction of buffalo herds by hunters (Criterion $A$ ).

While many of the individuals who participated in the buffalo industry as merchants, hunt organizers, hunters, skinners, and traders have remained anonymous, numerous others have assumed a degree of importance because of their financial success and business acumen. 
Some individuals involved in the industry were important for their development of marketing strategies and equipment used in the acquisition and treatment of the buffalo product, or for the leadership they demonstrated in opening up or supplying new frontier areas (Criterion B).

Camps that resulted from the activities of buffalo hunters occasionally included features such as dugouts. While such structures were not significant for the sophistication that may have distinguished urban structures related to the buffalo trade, they were noteworthy because they exemplified utilitarian, vernacular, frontier architecture (Criterion C).

Hunting camps located in the Rolling Plains region were key components within the economic system that resulted from the exploitation of the buffalo, and they were constructed and occupied at times by individuals who made significant contributions to that system. Their ephemeral character resulted from the nature of the buffalo hunting process and should not be considered to be a reflection on the significance of the role such camps played in the hunting economy. Indeed, because of the role the camps played, their significance equals that of any other more-visible three-dimensional structures resulting from the trade; without the hunting camps, there would have been no trading posts, and the complexity and variety of mercantile establishments and communities that were based on the marketing of the buffalo product would have been significantly lessened (Criterion D).

Registration Requirements

Buffalo hunting camps on the Rolling Plains were integral components within a larger economic system that included trading posts, urban mercantile establishments, towns and cities within which those establishments were located, and the railroads that served those merchants, providing goods essential to the gathering of the buffalo product and the transportation of the product to larger markets distant from the Plains. As important components of the trade, the camps are significant because they were irreplaceable elements of highly specialized trading systems, whether those systems were based in Kansas (for the Panhandle camps) or in north-central Texas (for the Rolling Plains camps).

Because of the variety of types of camps, including sites with permanent architectural features, camps with temporary architectural features, and those in which diagnostic artifacts alone identify the function of the site, and because the desirability of artifacts dating from the buffalo hunting period has made the camps targets of nonprofessional collectors, registration requirements should be sufficiently flexible to acknowledge the relative rarity, fragility, ephemeral character, and importance of the camps to the overall history of the Rolling Plains. To meet registration requirements, all buffalo hunting camps on the Rolling Plains should date from 1874 to 1879 . At camps where permanent shelter was present, sites should include sufficient architectural and archeological remains of the shelter to identify location, interior size, building materials. (such as those used for roof construction), indication of features associated with cooking and/or heating, and building orientation. Such sites also should include sufficient artifacts associated with buffalo hunting to allow the differentiation of the buffalo hunting camp and shelter from other camps and shelters occupied during the earliest years of agricultural development (ranching) on the Rolling Plains. At camps where permanent shelter was not present, sufficient artifacts should be present to suggest the areai extent and 
organization of the camp, to confirm its function, and to provide information about the period and duration of occupation and market sources of artifacts.

At the present time, only two such camps have been located and recorded in the Rolling Plains (41KG61 and 41GR528), and of those two sites, the function of only one (41GR528) has been verified by a preliminary examination of artifacts at the site and in private collections. As a result, registration requirements for properties representative of the buffalo hunting context are largely reflective of data available in primary and secondary documentary sources. Refinement of the registration requirements will depend on documentary research of greater depth and on the location, recording, assessment, testing, and archeological excavation of other similar sites within the Rolling Plains area.

National Register Assessment: 41GR528

CRITERION A: COMMERCE

Site 41GR528, a buffalo hunters camp, was an integral part of the commercial system of buffalo hunting on the Rolling Plains of Texas. This system included stands, hunting camps, and trading posts and stores, and had a significant impact on the development of larger urban centers which provided markets for the buffalo product (see Chapter 2).

\section{CRITERION D: RESEARCH POTENTIAL}

Site 41 GR528 is one of two recorded buffalo hunters camps in the western Rolling Plains. As such, and in view of the fact that no documentary evidence has been found that provides data about the camp, the site record may have the potential to provide information about market sources of artifacts in the Rolling Plains area.

\section{SITE INTEGRITY}

Site 41GR528 appears to have retained sufficient numbers of artifacts to identify its function as a buffalo hunters camp. However, in recent years, erosion has destroyed the dugout which was a component of the site, and repeated vandalism has resulted in the removal of numerous artifacts. As a result of these activities, 41GR528 has lost its integrity; the habitation component of the site is gone, the areal extent and organization of the camp cannot be distinguished, and it is not possible to determine the period and duration of its occupation. The dated isolated grave at the site could assist in establishing a period of occupation, but conflicts in archival data make this component of limited usefulness without archeological testing and excavation.

\section{ASSESSMENT OF ELIGIBILITY}

Site 41GR528 does not appear to be eligible for listing on the National Register of Historic Places. 
Ranching Sites on the Western Rolling Plains

Description

Ranching on the western Rolling Plains was the area's most important economic activity following the decimation of the buffalo herds in the late 1870 s and prior to the development of farming in the early twentieth century. It was the occupation in which virtually every occupant was engaged, and the economy of the area centered on the buying and selling, breeding, and care of livestock.

Two types of animals raised on the western Rolling Plains were sheep and cattle. The successful care of these animals depended on the acquisition of range, water, and shelter. The physical components required to carry out ranching activities and the marketing of animals included camps, headquarters and their constituent parts, towns with their mercantile establishments, holding pens, scouring mills, warehouses, and railroads that brought goods to the towns and transported livestock and livestock products such as wool out of the towns to larger markets.

During the period of open-range ranching on the western Rolling Plains, which lasted from approximately 1877 to 1890, properties associated with the sheep industry were very rare. Indeed, scholarly literature reviewed between 1987 and 1989 reported the presence of only two ranch headquarters--one in Borden County and one in Crosby County--and one series of rock corrals in southern Scurry County which may have represented the remains of a seasonally used camp. No detailed descriptions of these three sites were found in the literature. However, historical references to various sheep camps outside of the western Rolling Plains indicate that shelter might consist of a brush pile, a rag tent, or rock dugout, sometimes called a chosa. The relatively ephemeral nature of such shelters and the fact that they often were located on land owned by the State or by absentee property owners also may account for their absence in much of the historical literature.

Descriptions of camp life and sheep-herding practices on the western Rolling Plains also are poorly represented in the literature. However, because camps often were located at considerable distances from headquarters, they might be expected to include a full complement of items associated with self-sufficient maintenance of the herds and herders. Architectural and archeological features present at camps, therefore, would be associated with activities such as cooking and the provision of shelter for the herders and with gathering, penning, and sheltering of the herd. If the site was used during the lambing season, there might also be archeological evidence of tools or equipment utilized in the tasks occurring at that time.

Cattle camps and ranch headquarters during the period of open-range ranching were numerous in comparison with sheep camps and headquarters. Historical records describe more than 100 such properties in a six-county area that included Dickens, Crosby, Garza, Kent, Scurry, and Borden counties and was drained by the Brazos and Colorado river systems (see Table 7 and Fig. 3). Most of the camps and headquarters were established by ranchers who immigrated to the Rolling Plains from the Cross Timbers area, but a significant proportion of them were owned and operated by individual capitalists and companies with headquarters located outside of Texas. For the most part, the early camps and headquarters were supplied by Fort Griffin and Fort Worth between 1877 and 1881; after that date, supplies came 
from Colorado City and then Snyder, Justiceburg, and Post which received Santa Fe Railroad service in 1911.

Most archeological and architectural features present at cattle ranching sites resulted first from the need of ranchers to establish range control of a certain body of land and water when legal ownership was not desirable or not possible and second from the tasks which were required to care for cattle herds.

Because of the distance of the western Rolling Plains from market centers, earliest improvements almost always consisted of dugouts. Such structures usually were located in close proximity to a freshwater source and took any of a number of different forms. While the width of dugouts was limited by the size of roof-spanning members, variety of form was achieved by extending or contracting the length of the structure and by constructing single or multiple rooms. All dugouts had either a fireplace or a vent for metal stove installation.

In most cases, occupation of dugouts as primary residences lasted until the owner was able to acquire wood or stone to ereçt an above-ground home. At that point, the dugout might be used as a line camp, particularly if the new ranch headquarters was relocated. Various ranch hands then occupied it when making the rounds of the range.

Occasionally, line camps consisted of structures built above ground using locally avallable materials such as stone or logs. Such camps, however, were not the norm and represented a very small percentage of all camps described in the literature.

During the closed-range period, dugouts continued to be used for line camps. However, numerous new dugouts were constructed as homesteaders arrived, filed claims to land, and erected shelters that could be used to prove three-years' occupancy, a requirement for ownership. Other new dugouts were constructed by ranch employees as physical mechanisms by which ranch owners could continue to control state-owned School land they had previously leased. Both practices were so widespread that by 1905 it is possible that there was a dugout located on every eighth section of land in the western Rolling Plains region.

Like the open-range cattlemen who had preceded them, homesteaders replaced their dugouts with above-ground residences made of wood or stone when railroads made building materials generally available. Such structures usually were made of materials bought in Colorado City or Snyder, and they displayed architectural styles popular elsewhere in the region. Often, such homes were built during times of good weather and favorable markets and reflected the prosperity that resulted from large stock and crop production.

\section{Significance}

Archeological sites and architectural properties associated with ranching on the western Rolling Plains may be eligible for listing on the National Register of Historic Places under Criterion A because they "are associated with events that have made a significant contribution to the broad patterns of our history"; under Criterion B because they "are associated with the lives of persons significant in our past"; Criterion C because they "embody the distinctive characteristics of a type, period, or method of construction, or that represent the work of a master, or that possess high artistic values, or that 
CHAPTER 5: OUTLINE OF PROPERTY TYPES AND NATIONAL REGISTER ASSESSMENTS

represent a significant and distinguishable entity whose components may lack individual distinction"; or Criterion D because they "have yielded, or may be likely to yield, information important in prehistory or history" (U.S. Department of the Interior, National Park Service, National Register Division 1982:1).

Ranching was one of the most important activities that occurred on the western Rolling Plains after 1877. While sheep ranching was a very unusual occurrence, its presence in an area where competition between sheepmen and cattlemen must have been intense testifies to the strength, importance, and geographically widespread character of the sheep boom in the late 1870 s and throughout the 1880s. Cattle ranching, in contrast, was a widespread phenomenon that continued the economic prosperity initiated by buffalo hunting and spurred the growth of communities, businesses, and railroads throughout the State. The industry left a legacy of history, architecture, and folklore which persisted well beyond the years of greatest growth, and it continued to be a key component in the agricultural sector that dominated the Texas economy until World War II (Criterion A).

Because of the scarcity of sites associated with the sheep industry on the western Rolling Plains and the anonymity of those who participated in the business, it is impossible at this time to identify significant individual sheepmen in the area. On the other hand, numerous cattlemen already have been identified in historic literature. Many of them are known to have taken leading roles in opening West Texas to the cattle industry and permanent settlement. Others were important for their contributions to ranching technology, the building of towns, and the development of economic systems and ranching organizations that have persisted to the present day (Criterion B).

Both sheep and cattle camps frequently included features such as dugouts and corrals for penning animals. While such structures were not noteworthy for the sophistication that may have distinguished urban structures related to the livestock industry or rural ranch headquarters built after a variety of construction materials became readily available, they were noteworthy because they exemplified one of the most widespread forms of utilitarian, vernacular, frontier architecture (Criterion C).

Finally, ranching sites on the western Rolling Plains may yield information that is essential to understanding the spread and distribution of the sheep and cattle industries after 1877, adaptations that may have been required of ranchers as they moved westward from the Cross Timbers and Edwards Plateau, and inventions that resulted from the placement of sites far from sources of supply. In many cases, archeological sites are all that remain from the earliest period of Rolling Plains ranching, and they may constitute invaluable sources of data for defining variations among common housing types (Criterion D).

Registration Requirements

Sheep camps on the western Rolling Plains were rare but essential components. within a larger economic system that included ranch headquarters, urban mercantile establishments, towns and cities where those businesses were located, and the railroads that served those towns, providing goods essential to the running and maintenance of sheep ranches and camps and to the transportation of wool to larger markets. 
Sheep camps are believed to be extremely rare on the western Rolling Plains, and only two such sites are known to exist. Of those two sites, only one has been located and recorded (41GR443). Based on this small sample and on descriptions provided in historic documents, sheep camps on the western Rolling Plains should date from 1877 to ca. 1890 in order to meet registration requirements. At camps where permanent shelter was present, sites should include sufficient architectural and archeological remains to identify location, interior size of the shelter, building materials, and building orientation. In the absence of diagnostic elements such as sheep corrals, which should be sufficiently intact to indicate size, sheep camps should also include enough historic artifacts associated with the care of sheep to allow the differentiation of the sheep camps from other camps and shelters occupied during the earliest years of agricultural development (ranching) on the western Rolling Plains. At camps where permanent shelter was not present, sufficient artifacts should be present to suggest the areal extent and organization of the camp and its components, to confirm its function, and to provide information about the period and duration of occupation and market sources of artifacts. In the absence of diagnostic artifacts during survey and testing phases of archeological projects, establishment of site identity, function, and eligibility may depend on the availability of historical documents and oral histories.

At the present time, registration requirements for properties representative of the sheepherding context are based on data available in primary and secondary documentary sources and on an examination of one site (41GR443). Because of the apparent rarity of such sites on the western Rolling Plains, refinement of the registration requirements will depend on continued documentary research of greater depth, recognition and assessment of other sheepherding camps, and continued investigation of $41 \mathrm{GR} 443$.

Like sheep camps, cattle camps and ranch headquarters were key components within a large economic system that included mercantile establishments, towns and cities, railroads, and occasionally, foreign companies. The camps and headquarters were irreplaceable elements in an economic structure and were the basis for that structure.

Camps and ranch headquarters assumed a variety of forms and were widely distributed throughout the western Rolling Plains. Indeed, there probably is no other site type more numerous than the dugout utilized to establish ownership of a specific section of land or range. Such sites have been the objects of vandalism, but because of their frequency, a large number of early habitation sites associated with open- and closed-range cattle ranching that have a high degree of integrity still exist. It is believed, therefore, that registration requirements should be relatively demanding and stringent for this particular property type.

To meet registration requirements, cattle ranching sites on the western Rolling Plains should date from 1877 to 1939. At sites where permanent shelters such as dugouts were present, the architectural features should be sufficiently intact so that the interior and exterior size can be measured together with building materials (such as those used for roof or wall construction), indication of features associated with cooking and/or heating, building orientation, and relationship to water sources. Archeological deposits also should retain a high degree of integrity so that information can be derived from the site concerning market sources, activities of inhabitants, period and duration of occupation, and lifeways of the occupants. At sites where standing architecture is present, residential structures should be good examples of their architectural type and should not have been substantially modified since 1939. Ranch headquarters should include not only the 
main residence but also component parts such as outbuildings, corrals, and water tanks, or sufficient archeological deposits to identify the locations, functions, and dimensions of such site features.

At the present time, numerous cattle ranching camps and ranch headquarters have been identified and described in primary and secondary sources. A much smaller number have been recorded in the field, however. Therefore, refinement of the registration requirements will depend on documentary research of greater depth and on the location and architectural and/or archeological recording, assessment, testing, and excavation of similar sites within the western Rolling Plains area.

National Register Assessment: 41GR13

\section{CRITERION A: AGRICULTURE}

Site 41GR13, a ranch headquarters site established in the i.930s by Forrest Tuffing, from the period of closed-range ranching when diversified stock-farming operations were the typical agricultural units on the western Rolling Plains. Such operations occurred with great frequency throughout the area and were essential components in the overall economic health of the region (see Chapter 3 ).

\section{CRITERION C: ARCHITECTURE}

The Forrest Tuffing ranch headquarters includes the components that were typical of agricultural units in the early twentieth century. Among these components are a frame ranch house within a fenced-in area, a secondary frame house, a shed, corral, and stock tank. The primary residence originally stood in Burnham, a now-disappeared town located west of 4IGR13 adjacent to the Santa Fe Railroad. Prior to 1930 the house was moved to 41GR250, after which it was moved to its present location.

\section{SITE INTEGRITY}

Site 41 GR13 appears to have a high degree of integrity because of the completeness of the ranch headquarters component parts. Unfortunately, the main residence has been considerably altered since 1939; doors have been relocated, porches enclosed, and asphalt siding covers the building's exterior. As a result, the main residential structure on the site lacks architectural integrity.

No further field recording or archeological testing was undertaken during the Phase II study. Therefore, it is not possible to assess the archeological integrity of the site at this time.

\section{ASSESSMENT OF ELIGIBILITY}

Based on a lack of integrity, the architectural component at 41 GR13 is assessed to be ineligible for listing on the National Register of Historic Places. 
CRITERION A: TRANSPORTATION, AGRICULTURE

Sites 4 IGR203 and 41GR470 are the most visible remains in the Justiceburg area associated with the Gulf, Colorado and Santa Fe Railway. This important transportation route linked the agricultural community of the western Rolling Plains to distant markets for ranch and farm products while accelerating the rate at which commercial goods entered the region. The Railroad also contributed to the demise of commercial centers on more-distant lines while contributing dramatically to the prosperity of new communities on the Santa Fe route such as Justiceburg and Post (see Chapter 3 ).

\section{CRITERION C: ARCHITECTURE}

The Santa Fe Lake Complex (41GR470) is a functional, utilitarian engineering site designed to supply water to the steam locomotives on the Santa Fe line before their climb to the top of the Caprock Escarpment (Bryan et al. 1989:616). Site components that relate directly to water-supply functions include a concrete pumphouse, raised wooden walkways, a water-intake tower, an earthen dam, and a spillway below the dam. Site 41GR203 consists of a burned house associated with the Santa Fe Lake Complex.

\section{SITE INTEGRITY}

While the Santa Fe Lake Complex includes some components that have lost their integrity due to fire and surface disturbances (41GR203), the engineering features (41GR470) have retained a high degree of integrity.

\section{ASSESSMENT OF ELIGIBILITY}

Based on the significance and integrity of the engineering features at the Santa Fe Lake Complex, site 4IGR470 is assessed to be eligible for listing on the National Register of Historic Places. The eligibility of other site components cannot be assessed at this time because no further archeological or archival work was performed in 1988. Site 41GR203 is considered to have lost its integrity and does not appear to be eligible for listing on the National Register of Historic Places.

\section{National Register Assessment: 41GR250}

\section{CRITERION A: AGRICULTURE}

Site 41GR250, a ranch headquarters established by Forrest Tuffing in the 1920s, dates from the period of closed-range ranching when diversifieid stock-farming operations were the typical agricultural units on the western Rolling Plains. Operations such as that owned by Tuffing were common throughout the area and were important components in the region's economic structure (see Chapter 3 ). 


\section{CRITERION D: RESEARCH POTENTIAL}

Site 41 GR250 is one of numerous similar stock-farming operations about which there is considerable documentary and statistical information currently available.

\section{SITE INTEGRITY}

The Forrest Tuffing ranch headquarters consists entirely of archeological deposits; no standing structures are present on the site, and the 1987 archeological survey was unable to differentiate the locations, functions, and dimensions of typical site features such as outbuildings, corrals, and water tanks.

ASSESSMENT OF ELIGIBILITY

Site 41GR250 does not appear to be eligible for listing on the National Register of Historic Places.

National Register Assessment: 41GR263

\section{CRITERION A: AGRICULTURE}

Site 41GR263, established in 1900 by OS cowboy Walter Roy, dates from the important period on the western Rolling Plains when passage of new State legislation and the in-migration of large populations of homesteaders signaled a change from open-range to closed-range economies. Dugouts such as that at 41GR263 not only provided shelter for cowboys but also provided their employers with a mechanism to retain control of large areas of previously open range (see Chapter 3 ).

\section{CRITERION B: IMPORTANT INDIVIDUALS}

Walter Roy, who built the dugout at 41GR263, was an important figure in Garza County. With fellow OS cowboys, Roy contributed to the prosperity of the OS Ranch and agricultural development of southeastern Garza County, first as an employee of Andy and Francis Long, and then of E. W. Clark, John Scharbauer, and Wilson Edward Connell. Later Roy served on the County's first Commissioners Court.

\section{CRITERION C: ARCHITECTURE}

Dugouts such as that at 41GR263 were one of the most widespread forms of utilitarian, vernacular, frontier architecture in the late nineteenth and early twentieth centuries. They represented a direct response to mandates created by changing laws and to specific functional requirements created by climate and availability of building materials. 


\section{CRITERION D: RESEARCH POTENTIAL}

Site 41GR263 is one of a number of late nineteenth- and early twentieth-century dugouts that have been recorded on the western Rolling Plains. At this time, considerable documentary information is available about such structures. For that reason, the archeological research potential of the site may be restricted to specific questions concerning the prerailroad material culture of the project area.

\section{SITE INTEGRITY}

The Walter Roy dugout site appears to have site integrity. Structural locations are clearly visible, and the general size, orientation, and relationship to water sources can be determined. The hearth area can be distinguished, and there may be subsurface deposits.

\section{ASSESSMENT OF ELIGIBILITY:}

The Walter Roy dugout is assessed to be eligible for listing on the National Register of Historic Places.

\section{National Register Assessment: 41GR331}

\section{CRITERION A: AGRICULTURE}

Site 41GR331, the former location of a building within the historic Burnham townsite, probably dates to 1910 when L. E. Lasseter and J. W. Person, representatives for the Brazos Valley Townsite Corporation, platted a town adjacent to the newly constructed Gulf, Colorado and Santa Fe Railway. The purpose of the Corporation's action was to promote and sell town lots to the scores of immigrants who Lassiter and Person assumed would arrive on the Railroad. The townsite thus was a representative example of the scores of similar promotions which occurred throughout West Texas between 1895 and the 1920s as the area's economy changed from one based solely on livestock to one in which crop production played an increasingly important role (see Chapter 3).

\section{CRITERION D: RESEARCH POTENTIAL}

Towns of the early twentieth century which resulted from the promotion of ranch lands by rallroad and other land companies are important historic sites. Because they were developed and occupied at a time when regional demographics were changing dramatically and because they were almost always related in some way to improved transportation routes, such historic sites may have the potential for answering important questions about changes in social structure and regional economies. However, the research potential of a single site may be significantly less than that of the townsite complex when studied as a whole. In addition, data about regional economies and changes in demographics and social structures at this pivotal period on the plains are extremely rich. For these reasons, the research potential of 41 GR331 may be limited. 


\section{SITE INTEGRITY}

Site 41GR331 appears to have archeological integrity. However, the integrity of the Burnham townsite, of which 41GR331 is only one small component, is an important issue due to the limited research potential of 41 GR331 alone. At this time, archeological data concerning the townsite are not available.

\section{ASSESSMENT OF ELIGIBILITY}

Site 4IGR331 does not appear to be eligible for listing on the National Register of Historic Places. The site, when isolated from the townsite of which it is only one component, has limited significance. In addition, insufficient data are avallable to suggest what research potential Burnham townsite might have beyond that available in the documentary resources.

National Register Assessment: 41GR392 ;

\section{CRITERION A: AGRICULTURE}

Site 41GR392, constructed and occupied in 1900 by OS cowboy N. P. Pyron, was later owned and occupied by OS cowboy O. H. Curtis and rancher N. N. Rodgers. The site dates from the pivotal period on the western Rolling Plains when passage of the Four-Section Act by the State Legislature and the movement of large numbers of farmers into the area stimulated a change from an open-range to a closed-range economy. Dugouts such as 41 GR392 provided shelter for cowboys while serving as a mechanism for the cattle companies for which they worked to continue to control large areas of previously open range (see Chapter 3 ).

\section{CRITERION C: ARCHITECTURE}

Dugouts such as that at 41 GR392 were one of the most widespread forms of utilitarian, vernacular, frontier architecture in the late nineteenth and early twentieth centuries. They represented a direct response to mandates created by changing laws and to specific functional requirements created by climate and availability of building materials.

\section{CRITERION D: RESEARCH POTENTIAL}

Site 41 GR392 is one of a number of turn-of-the-century dugouts which have been recorded on the western Rolling Plains. At this time, considerable documentary information is available about such structures in general, and 41GR392 in particular. However, the site appears to have been one which was occupied both before and after the arrival of the Santa Fe Railroad. Thus, 41 GR392 may have the potential to answer questions concerning the dramatic changes in the region's economy and material culture which occurred after 1910. 
SITE INTEGRITY

The Pyron-Curtis-Rodgers dugout site appears to have a high degree of integrity. The location of the dugout is clearly visible as is its orientation, the location of the fireplace, interior and exterior size, construction materials, and distance from water sources.

ASSESSMENT OF ELIGIBILITY

Site 41 GR392 appears to be eligible for listing on the National Register of Historic Places.

National Register Assessment: 41GR443

\section{CRITERION A: AGRICULTURE}

Site 41GR443 was constructed and occupied by the early 1890s by unidentified sheepherders, and then occupied by os cowboy S. D. "Dee" Boren as a homestead claim after 1900. The site is associated with sheep ranching, one of the most important economic activities in West Texas during the 1880.s and early 1890s and also with cattle ranching after the late 1890s when it was utilized as a mechanism by the OS Cattle Company for maintaining control of what had previously been open range. During both periods, the camp served as an important physical component within the larger structure of the ranching industry (see Chapter 3).

\section{CRITERION C: ARCHITECTURE}

Site 41GR443 includes two important architectural elements. The first, a rock corral, distinguishes the site from all others in the project area and is one of only two such corrals mentioned in historic documents or recorded in the Rolling Plains area. It is a typical example of rock corrals utilized to pen sheep during the last quarter of the nineteenth century and is the feature which defines the site's function.

The second architectural element at 41 GR443 is the remains of a stone dugout. Such structures were widespread on the Rolling Plains. They were examples of utilitarian, vernacular, frontier architecture that was constructed in response to specific functional requirements created by climate and availability of building materials.

\section{CRITERION D: RESEARCH POTENTIAL}

Because of the scarcity of historic sites on the Rolling Plains that are associated with the sheep industry, and because such sites are infrequently recorded in the documentary literature, the research potential of 41 GR 443 is extremely high. Presently, it is not known whether the area between the Caprock and Double Mountains was utilized by Hispanic sheepherders from New Mexico or West Texas, and there is no indication of the extent of the range utilized by the few sheep ranchers who have been identified on or adjacent to the Rolling Plains in the 1880s and 1890s. Finally, the adaptive reuse of the site by an 
individual involved in cattle ranching may offer interesting insights into differences and similarities between the sheep and cattle industries.

\title{
SITE INTEGRITY
}

Site 41 GR443 appears to be the best preserved of all the historic sites in the Justiceburg Reservoir project area. Site features are intact, and it is possible to identify the interior and exterior sizes of the dugout, building materials, and building orientation.

ASSESSMENT OF ELIGIBILITY

Site 41 GR443 is assessed to be eligible for listing on the National Register of Historic Places.

\author{
National Register Assessment: 41GR474
}

\section{CRITERION A: AGRICULTURE}

Site 41GR474, a ranch headquarters site established in December 1899 by Jeff Justice and occupied by the Justice family through the 1920s, dates from the pivotal period in West Texas when the agricultural economy was changing from open range to closed range. During the post-1900 period, numerous migrants from other areas moved into the western Rolling Plains area, homesteading blocks for four sections and practicing diversified stock farming. Such operations were common throughout the area and contributed to the region's economic vitality (see Chapter 3 ).

\section{CRITERION B: IMPORTANT INDIVIDUALS}

Site 41GR474 was occupied by Jeff Justice, who lived first in the dugout component of the site and later in a late Victorian frame residence. Justice was a prominent rancher on the western Rolling Plains who platted and promoted the town of Justiceburg.

\section{CRITERION D: RESEARCH POTENTIAL}

Site 41GR474 is one of many turn-of-the-century ranch headquarters which have been recorded on the western Rolling Plains. At this time, considerable documentary information is available about such complexes, many of which have survived intact. In addition, there is considerable information available concerning 41GR474. On the other hand, the two residential components--the dugout and housesite--appear to have been occupied sequential1y, one before the construction of the Santa Fe Railroad and the other after the Railroad's construction. Furthermore, the dugout appears not to have been occupied or otherwise used after 1910. As a result, the site may have the potential to answer questions concerning the dramatic changes in the region's economy and material culture which occurred between 1899 and World War I. 


\title{
SITE INTEGRITY
}

The dugout at 41GR474 appears to have a moderate degree of integrity, and data can be collected concerning architectural features, interior and exterior dimensions, and orientation. The ranch house feature and surrounding area likewise appear to have sufficient integrity to allow the identification of building locations, functions, and dimensions. Archeological deposits at both features seem to retain a sufficiently high degree of integrity to allow the derivation of information about market sources, activities of inhabitants, period and duration of occupation, and lifeways of the occupants.

\section{ASSESSMENT OF ELIGIBILITY}

Site 4lGR474 is assessed to be eligible for listing on the National Register of Historic Places.

\author{
National Register Assessment: 41KT42 ;
}

\section{CRITERION A: AGRICULTURE}

Site 41KT42, a cattle company line camp site, spans the period of open-range and closed-range ranching. Located on one of the few sections in the project area that was patented and owned by a cattle company during the open-range period, the site is an example of an essential element in the ranching industry. Located at strategic places within the range controlled by a cattle company, such line camps provided shelter to ranch employees as they carried out seasonal tasks (see Chapter 3 ).

\section{CRITERION D: RESEARCH POTENTIAL}

Cowboy line camps such as 41KT42 were often similar in type to homestead claims such as 41GR263. The two property types differed in purpose, however, with line camps providing shelter to numerous ranch employees over a number of successive seasons and homestead claims providing a mechanism for control of what had previously been open range. As a result, site $41 \mathrm{KT} 42$ may have considerable potential for providing information about changes in the material culture of cowboy line camps between the 1880s and the 1920s, and in features which may have distinguished the Company-owned site from the employee-owned site.

\section{SITE INTEGRITY}

Site 41KT42 appears to have a high degree of integrity. The site is sufficiently intact to distinguish the building's size, interior and exterior dimensions, and orientation. Enough site features seem to be present to identify their locations, functions, and dimensions. 
ASSESSMENT OF ELIGIBILITY

Site 41 KT42 appears to be eligible for listing on the National Register of Historic Places.

National Register Assessment: $41 \mathrm{KT} 84$

CRITERION A: AGRICULTURE

Site 41KT84, a cattle company line camp site, spans the period of open-range and closed-range ranching. Located on one of the few sections in the project area that was patented and owned by a cattle company during the open-range period, the site is an example of an essential element in the ranching industry. Located at strategic places within the range controlled by a cattle company, such line camps provided shelter to ranch employees as they carried out seasonal tasks (see Chapter 3 ).

CRITERION D: RESEARCH POTENTIAL

Cowboy line camps such as $41 \mathrm{KT} 84$ and $41 \mathrm{KT} 42$ were often similar in type to homestead claims such as 41GR263. The two property types differed in purpose, however, with line camps providing shelter to numerous ranch employees over a number of successive seasons and homestead claims providing a mechanism for control of what had previously been open range. As a result, site $41 \mathrm{KT} 84$ may have considerable potential for providing information about changes in the material culture of cowboy line camps between the 1880s and the 1920s, and in features which may have distinguished the Company-owned site from the employee-owned site.

SITE INTEGRITY

Site 41KT84 appears to have a high degree of integrity. The site is sufficiently intact to distinguish the building's size, interior and exterior dimensions, and orientation. Enough site features seem to be present to identify their locations, functions, and dimensions.

ASSESSMENT OF ELIGIBILITY

Site 41KT84 appears to be eligible for listing on the National Register of Historic Places. 

REFERENCES CITED

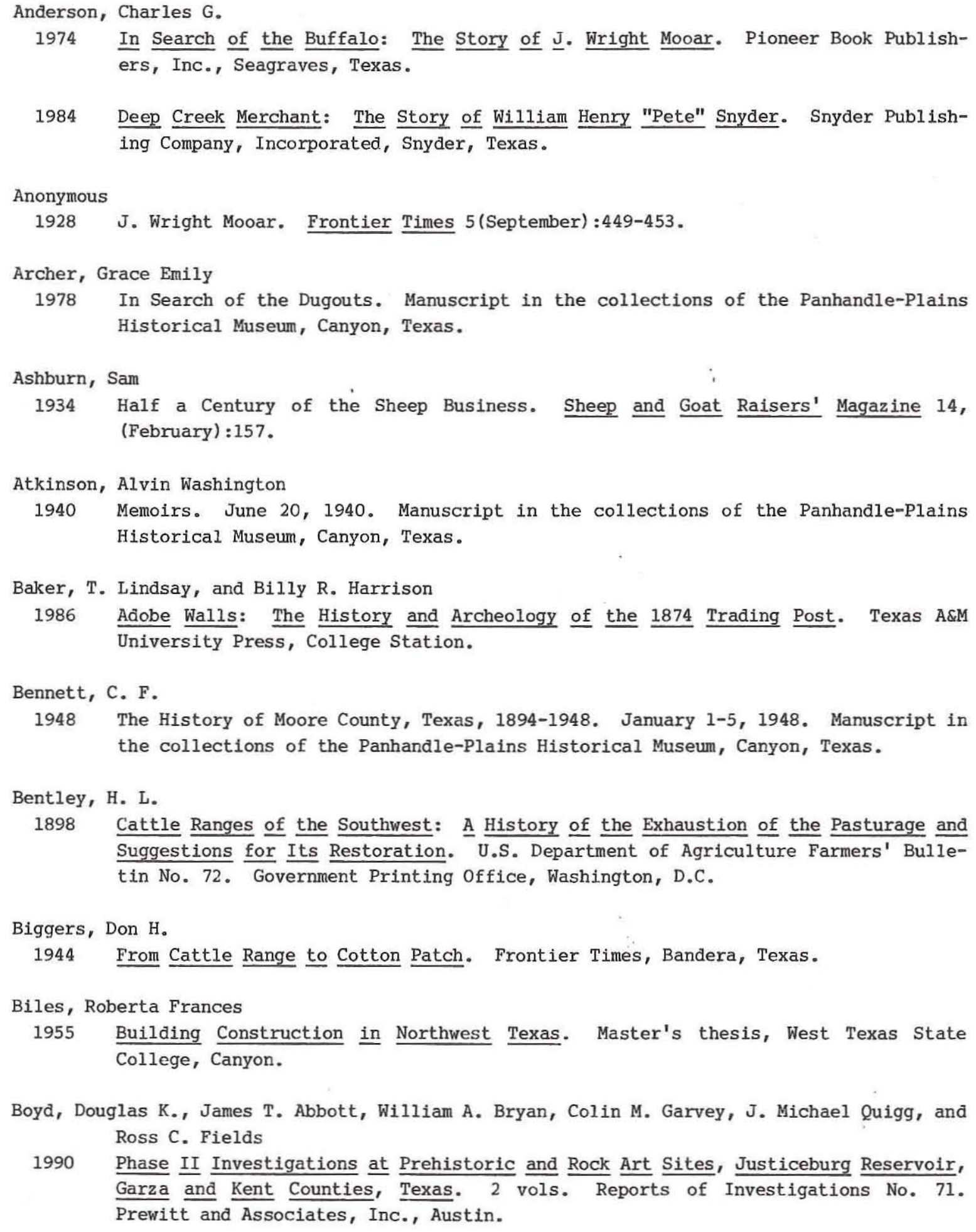

1898 Cattle Ranges of the Southwest: A History of the Exhaustion of the Pasturage and Suggestions for Its Restoration. U.S. Department of Agriculture Farmers' Bulletin No. 72. Government Printing Office, Washington, D.C.

Boyd, Douglas K., James T. Abbott, William A. Bryan, Colin M. Garvey, J. Michael Quigg, and Ross C. Fields

1990 Phase II Investigations at Prehistoric and Rock Art Sites, Justiceburg Reservoir, Garza and Kent Counties, Texas. 2 vols. Reports of Investigations No. 71. Prewitt and Associates, Inc., Austin. 
Boyd, Douglas K., Martha Doty Freeman, Michael D. Blum, Elton R. Prewitt, and J. Michael Quigg

1989 Phase I Cultural Resources Investigations at Justiceburg Reservoir on the Double Mountain Fork of the Brazos River, Garza and Kent Counties, Texas. 2 vols. Reports of Investigations No. 66. Prewitt and Associates, Inc., Austin.

Branch, E. Douglas

1929 The Hunting of the Buffalo. D. Appleton and Company, New York.

Bryan, William A., Martha Doty Freeman, and Margaret Ann Howard

1989 Historic Site Descriptions. Appendix G in Phase I Cultural Resources Investigations at Justiceburg Reservoir on the Double Mountain Fork of the Brazos River, Garza and Kent Counties, Texas, by Douglas K. Boyd, Martha Doty Freeman, Michael D. Blum, Elton R. Prewitt, and J. Michael Quigg, pp. 577-643. Reports of Investigations No. 66, Volume II. Prewitt and Associates, Inc., Austin.

Carlson, Paul H.

1982 Texas Woollybacks: The Range Sheep and Goat Industry. Texas A\&M University Press, College Station, Texas.

1985 Bankers and Sheepherders in West Texas. The West Texas Historical Association Year Book 61:5-14.

Carter, Mrs. J.W.

1927 Mrs. J. W. Carter, Dimmitt, Texas to J. Evetts Haley. October 31, 1927. Manuscript in the collections of the Panhandle-Plains Historical Museum, Canyon, Texas.

Chenoweth, Elizabeth

n.d. Ranching in the Early West. Manuscript in the collections of the PanhandlePlains Historical Museum, Canyon, Texas.

Collinson, Frank

1963 Life in the Saddle. Edited by Mary Whatley Clarke. University of Oklahoma Press, Norman.

Cook, John R.

1907 The Border and the Buffalo: An Untold Story of the Southwest Plains. Crane \& Company, Topeka, Kansas.

Dennis, Dorothy

1971 Major Willa Viley Johnson. Borden Citizen 6 (June):2.

Didway, Charles (editor)

1973 Wagon Wheels: A History of Garza County. Pioneer Book Publishers, Seagraves, Texas.

Dorwood, Mrs. David

1958 C. Boone McClure. Interview--Mrs. David Dorwood, Gail, Texas, May 20, 1958. Manuscript in the collections of the Panhandle-Plains Historical Museum, Canyon, Texas. 


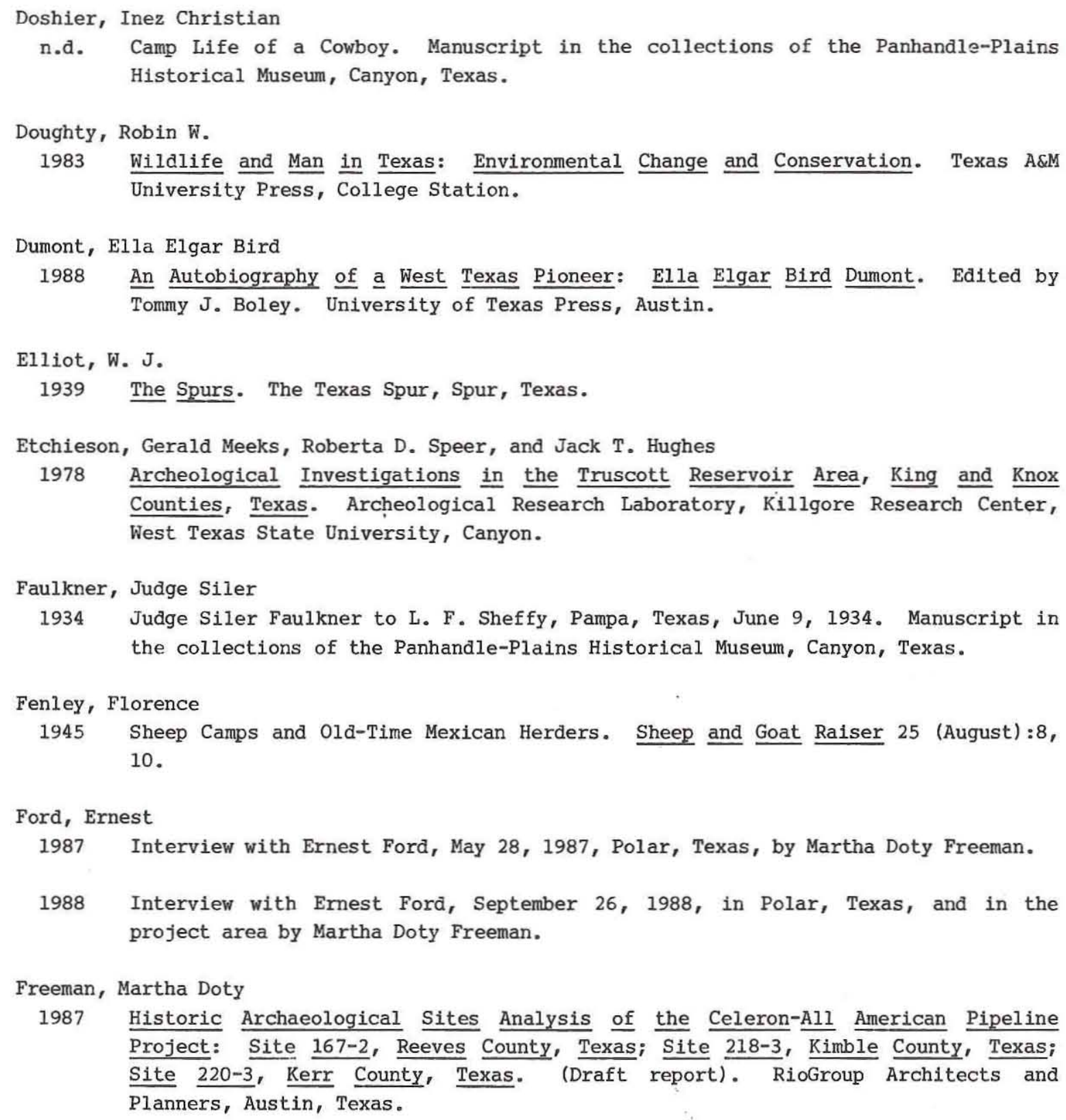
Counties, Texas. Archeological Research Laboratory, Killgore Research Center, West Texas State University, Canyon.

Faulkner, Judge Siler

1934 Judge Siler Faulkner to L. F. Sheffy, Pampa, Texas, June 9, 1934. Manuscript in the collections of the Panhandle-Plains Historical Museum, Canyon, Texas.

Fenley, Florence

1945 Sheep Camps and Old-Time Mexican Herders. Sheep and Goat Raiser 25 (August):8, 10.

Ford, Ernest

1987 Interview with Ernest Ford, May 28, 1987, Polar, Texas, by Martha Doty Freeman.

1988 Interview with Ernest Ford, September 26, 1988, in Polar, Texas, and in the project area by Martha Doty Freeman.

Freeman, Martha Doty

1987 Historic Archaeological Sites Analysis of the Celeron-All American Pipeline Project: Site 167-2, Reeves County, Texas; Site 218-3, Kimble County, Texas; Site 220-3, Kerr County, Texas. (Draft report). RioGroup Architects and Planners, Austin, Texas.

1989a Regional Historical Background. Chapter 4 in Phase I Cultural Resources Investigations at Justiceburg Reservoir on the Double Mountain Fork of the Brazos River, Garza and Kent Counties, Texas, by Douglas K. Boyd, Martha Doty Freeman, Michael D. Blum, Elton R. Prewitt, and J. Michael Quigg, pp. 61-67. Reports of Investigations No. 66, Volume I. Prewitt and Associates, Inc., Austin.

1989b Historic Resources in Justiceburg Reservoir. Chapter 9 in Phase I Cultural Resources Investigations at Justiceburg Reservoir on the Double Mountain Fork of the Brazos River, Garza and Kent Counties, Texas, by Douglas K. Boyd, Martha Doty Freeman, Michael D. Blum, Elton R. Prewitt, and J. Michael Quigg, pp. 133-156. Reports of Investigations No. 66, Volume I. Prewitt and Associates, Inc., Austin. 
Freeman, Martha Doty, and Joe C. Freeman

1981 A Cultural Resources Inventory and Assessment of the Proposed Stacy Reservoir, Concho, Coleman, and Runnels Counties, Texas. Volume II: Historic Cultural Resources. Espey, Huston and Associates, Inc., Austin.

Gard, Wayne

1959a The Great Buffalo Hunt. Alfred A. Knopf, New York.

1959b The Mooar Brothers, Buffalo Hunters. The Southwestern Historical Quarterly 63 (July) :31-45.

Garnsey, Jean

[1952] First Family of Amarillo. Typescript in the collections of the Panhandle-Plains Historical Museum, Canyon, Texas.

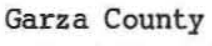




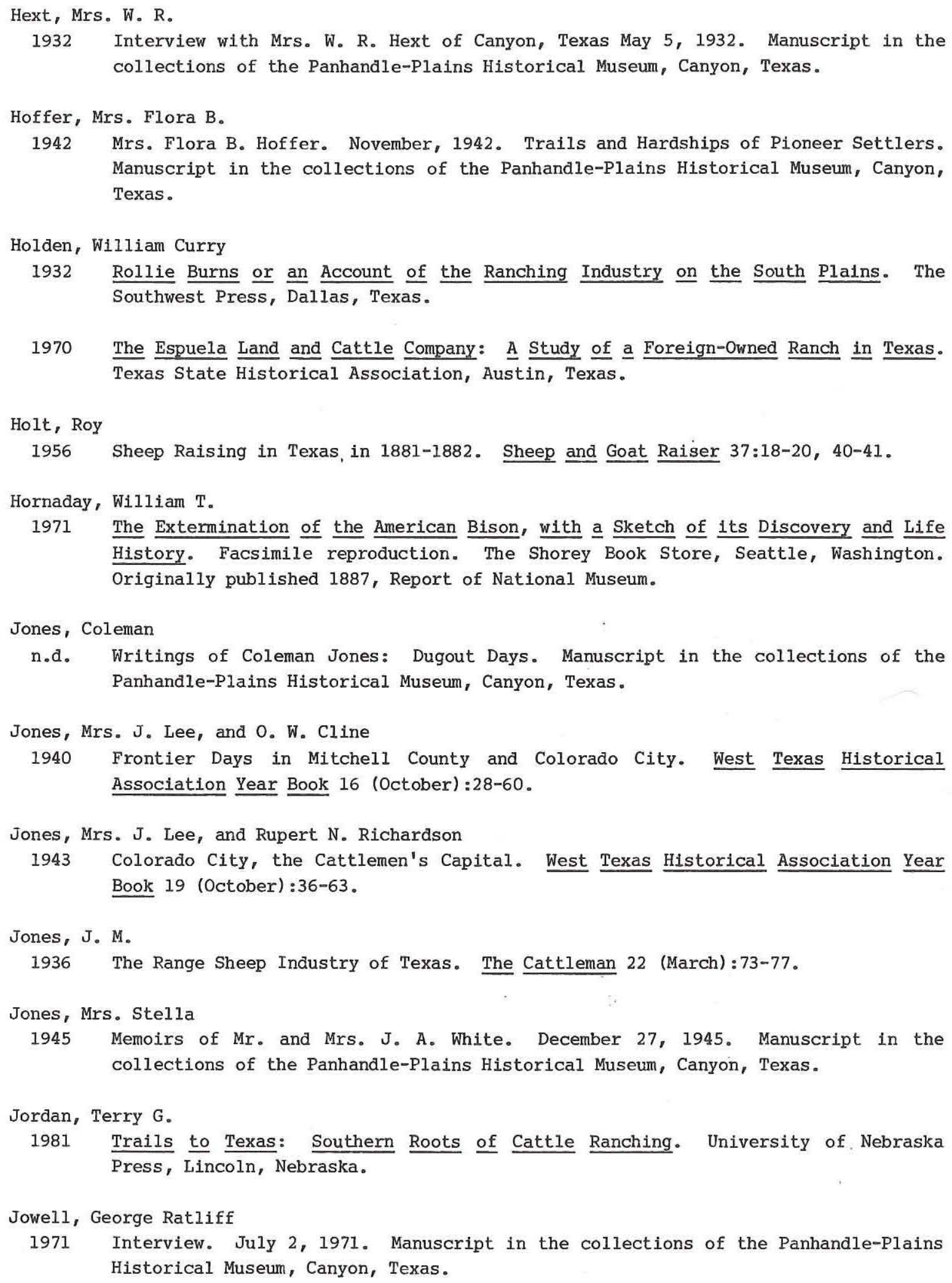

1970 The Espuela Land and Cattle Company: A Study of a Foreign-Owned Ranch in Texas. Texas State Historical Association, Austin, Texas. 


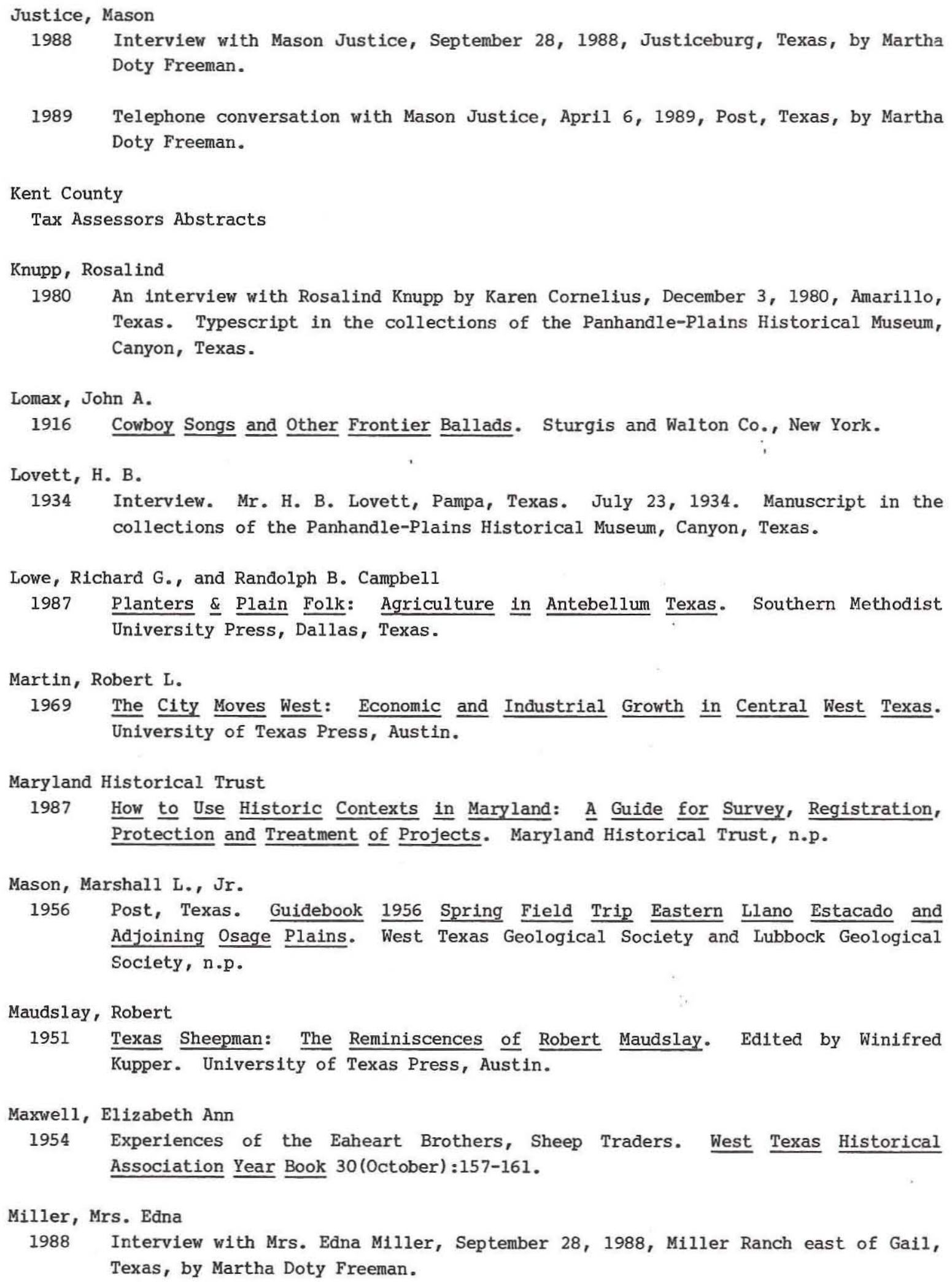




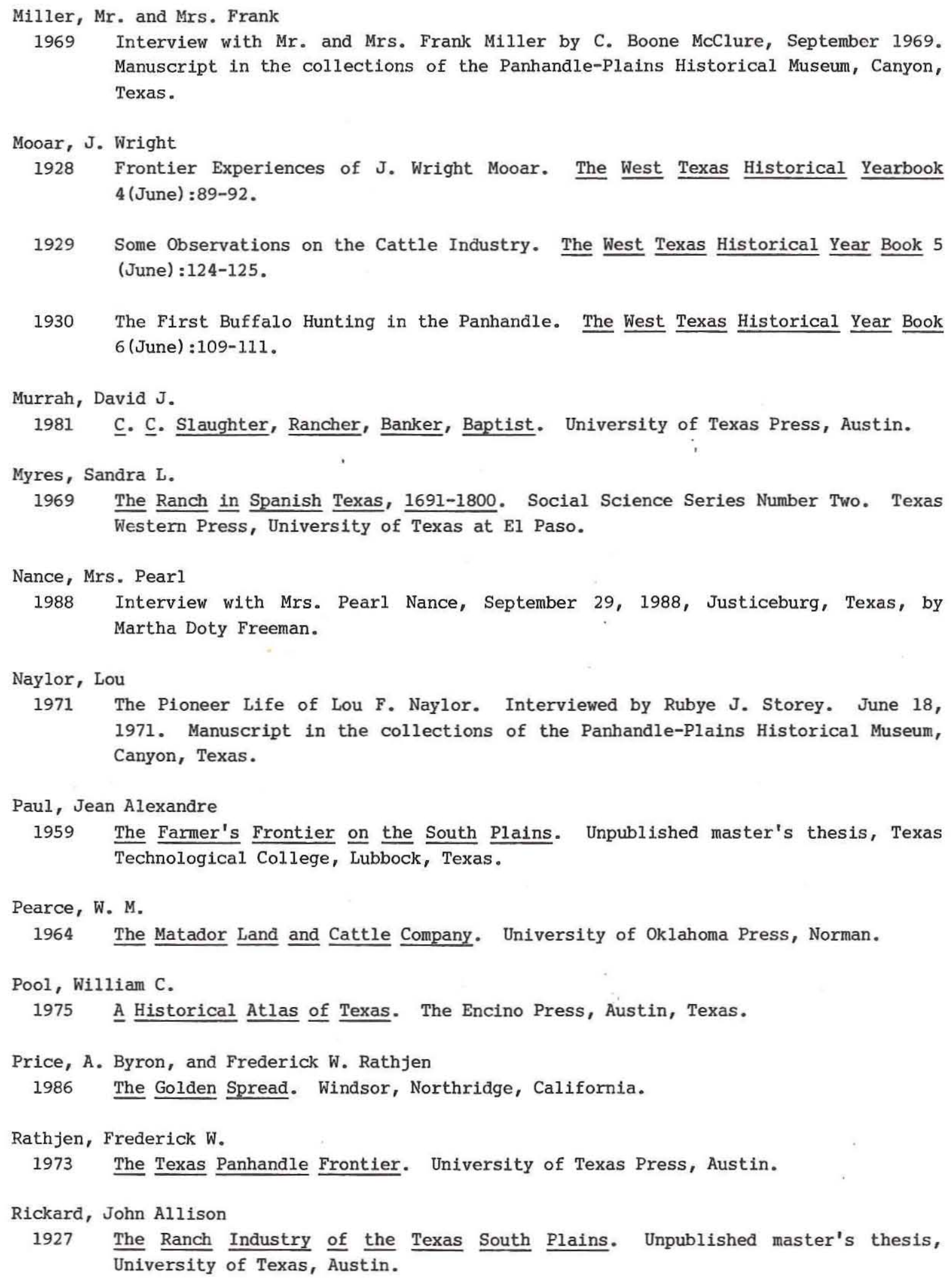

1969 The Ranch in Spanish Texas, 1691-1800. Social Science Series Number Two. Texas Western Press, University of Texas at El Paso.

Nance, Mrs. Pearl

1988 Interview with Mrs. Pearl Nance, September 29, 1988, Justiceburg, Texas, by Martha Doty Freeman.

Naylor, Lou

1971 The Pioneer Life of Lou F. Naylor. Interviewed by Rubye J. Storey. June 18, 1971. Manuscript in the collections of the Panhandle-Plains Historical Museum, Canyon, Texas.

Paul, Jean Alexandre

1959 The Farmer's Frontier on the South Plains. Unpublished master's thesis, Texas Technological College, Lubbock, Texas.

Pearce, W. M.

1964 The Matador Land and Cattle Company. University of Oklahoma Press, Norman.

Pool, William C.

1975 A Historical Atlas of Texas. The Encino Press, Austin, Texas.

Price, A. Byron, and Frederick W. Rathjen

1986 The Golden Spread. Windsor, Northridge, California.

Rathjen, Frederick W.

1973 The Texas Panhandle Frontier. University of Texas Press, Austin.

Rickard, John Allison

1927 The Ranch Industry of the Texas South Plains. Unpublished master's thesis, University of Texas, Austin. 
Rister, C. C.

1929 The Significance of the Destruction of the Buffalo in the Southwest. The Southwestern Historical Quarterly 33 (July):34-49.

Roe, Frank Gilbert

1972 The North American Buffalo: A Critical Study of the Species in its Wild State. University of Toronto Press, Toronto, Ontario, Canada.

Roemer, Ferdinand

1935 Texas with Particular Reference to German Immigration and the Physical Appearance of the Country. Translated by Oswald Mueller. Standard Printing Company, San Antonio.

Rogers, Mondel

1976 Ranches of the Texas Plains: Paintings by Mondel Rogers. Foreward by Mitchell A. Wilder. Texas A\&M University Press, College Station, Texas.

Shedd, Emmett

1988 Telephone conversation with Emmett Shedd, September 29, 1988, Post, Texas, by Martha Doty Freeman.

Smith, Mrs. Maudie

1988 Telephone conversation with Mrs. Maudie Smith, September 28, 1988, Post, Texas, by Martha Doty Freeman.

Snyder, Texas Unit of the Ranch Headquarters Association (Ranching Heritage Association) (compiler)

1986 Early Ranching in West Texas. Braun-Brumfield, Inc., Ann Arbor, Michigan.

Steely, James Wright (compiler)

1984 A Catalog of Texas Properties in the National Register of Historic Places. Texas Historical Commission, Austin.

Taylor, A. J.

1980 A Survey of New Mexican Pastores in the Texas Panhandle-Plains 1876-1886. Manuscript prepared for the Texas Historical Foundation.

Texas. General Land Office

1873a Fannin Scrip 6187. Abstract 145. H\&GN Railway Company Certificate No. 12/2409. Patented to original, December 9, 1873.

1873b Fannin Scrip 6070. Garza Abstract 2060, Kent Abstract 122. H\&GN Railway Company Certificate No. 6/1029. Patented to original, December 27, 1873.

1873c Fannin Scrip 6006. Kent Abstract 58. H\&GN Railway Company Certificate No. 6/965. Patented to original, December 27, 1873.

Texas. Twenty-Fourth Legislature

1895 Revised Civil Statutes of the State of Texas. Adopted at the Regular Session of the Twenty-Fourth Legislature. Eugene Von Boeckmann, Austin, Texas. 
Texas Wool. Volume 1. July 1881.

Texas Wool. Volume 1. February 1882.

Thurmond, J. Peter, Martha Doty Freeman, and Susan L. Andrews

1981 A Preliminary Assessment of the Cultural Resources in the Brazos Natural Salt Pollution Control Project, Kent, King, and Stonewall Counties, Texas. Reports of Investigations No. 18. Prewitt and Associates, Inc., Austin.

Towne, Charles Wayland, and Edward Norris Wentworth

1945 Shepherd's Empire. University of Oklahoma Press, Norman, Oklahoma.

Truett, Joe C., and Daniel W. Lay

1984 Land of Bears and Honey: $\underline{A}$ Natural History of East Texas. University of Texas Press, Austin.

Upfold, Mr. and Mrs. E. A.

1945 Mr. and Mrs. E. A. Upfold to Betty Joe Greer. Canyon, Texas, February 24, 1945. Manuscript in the collections of the Panhandle-Plains Historical Museum, Canyon, Texas.

U.S. Department of the Interior

1983 Archeology and Historic Preservation; Secretary of the Interior's Standards and Guidelines. Federal Register 48(190) (September 29):44,716-44, 727.

U.S. Department of the Interior, National Park Service, National Register Division 1982 How to Apply the National Register Criteria for Evaluation. National Park Service, Department of the Interior, Washington, D.C.

Webb, Walter Prescott

1931 The Great Plains. Grosset and Dunlap, New York.

Weniger, Del

1984 The Explorers' Texas: The Lands and Waters. Eakin Press, Austin.

Wentworth, Col. E. N.

1939 Sheep Trails of Early Texas. The Southwestern Sheep and Goat Raiser 9 (June):7, $35,37,39$; (July):23, 34 .

1943 The Golden Fleece in Texas. Sheep and Goat Raiser 24 (December):16, 20, 25-32.

Whiteside, Leonard A.

1948 Interview. Leonard A. Whiteside to John E. Johnson. January 13, 1948. Manuscript in the collections of the Panhandle-Plains Historical Museum, Canyon, Texas.

Williams, J. W.

1954 The Big Ranch Country. Terry Brothers, Printers, Wichita Falls, Texas.

Williams, William Wayne

1988 Conversation with William Wayne Williams, September 28, 1988, Post, Texas, by Martha Doty Freeman. 
Wilson, James A.

1983 Hide and Horn in Texas: The Spread of Cattle Ranching, 1836-1900. American Press, Boston, Massachusetts.

Wilson, Jim P.

1928 Mr. Jim P. Wilson, Alpine, Texas, to J. Evetts Haley. January 1, 1928. Manuscript in the collections of the Panhandle-Plains Historical Museum, Canyon, Texas.

Woody, J. W.

1926 Interview with J. W. Woody by J. Evetts Haley, October 19, 1926, Snyder, Texas. Typescript in the collections of the Panhandle-Plains Historical Museum, Canyon, Texas.

1928 Interview with J. W. Woody by J. Evetts Haley, February 11, 1928, Snyder, Texas. Typescript in the collections of the Panhandle-Plains Historical Museum, Canyon, Texas. 
APPENDIX: Artifact Analysis

Douglas K. Boyd 

Of the 536 historic artifacts collected from six sites (Table 8), 9 were incidentally recovered at three prehistoric sites, and 527 were recovered during the investigations at three historic sites.

TABLE 8

PROVENIENCE OF HISTORIC ARTIFACTS

\begin{tabular}{|c|c|c|c|c|c|c|c|}
\hline \multirow[b]{2}{*}{ Material Classification } & \multicolumn{3}{|c|}{ Prehistoric Sites } & \multicolumn{3}{|c|}{ Historic Sites } & \multirow[b]{2}{*}{ Totals } \\
\hline & $41 \mathrm{GR} 383$ & 41GR456 & $41 \mathrm{KT} 51$ & 41GR4 74 & 41GR528 & $41 \mathrm{KT} 42$ & \\
\hline Metal & - & 1 & 6 & 95 & 6 & 31 & 139 \\
\hline Ceramic & '- & - & - & 63 & 1 & 7 & 71 \\
\hline Glass & 2 & - & - & 160 & 3 & 11 & 176 \\
\hline Rubber & - & - & - & 1 & - & 1 & 2 \\
\hline Leather & - & - & - & 54 & - & 1 & 55 \\
\hline Bone & - & - & - & 81 & - & 6 & 87 \\
\hline Shell & - & - & - & 1 & - & - & 1 \\
\hline Wood & - & - & - & - & - & 3 & 3 \\
\hline Other & $=$ & $=$ & $=$ & 2 & $=$ & $=$ & 2 \\
\hline Totals: & 2 & 1 & 6 & 457 & 10 & 60 & 536 \\
\hline
\end{tabular}

HISTORIC ARTIFACTS FROM PREHISTORIC SITES

The nine items collected from prehistoric sites consist of two fragments of unidentified purple glass from the surface at 41GR383; a 7/8-inch metal bolt head from $10-20 \mathrm{~cm}$ below the surface at 41GR456; and a wire fragment, three single-twist barbs from barbed wire, and two wire staples from $0-20 \mathrm{~cm}$ below the surface at $41 \mathrm{KT} 51$. All of these items are evidence of historic or recent disturbance.

HISTORIC SITE $41 \mathrm{GR} 474$

Historic artifacts were recovered from five proveniences representing two separate occupations at 41GR474 (Table 9). Some of the artifacts are clearly associated with the original occupation of the dugout, while others are associated with the later occupation of the frame house (see Chapter 4). Some represent a mixed assemblage and could be associated with either occupation. 
TABLE 9

HISTORIC ARTIFACTS, 41GR474

\begin{tabular}{|c|c|c|c|c|c|c|}
\hline \multirow[b]{2}{*}{$\begin{array}{l}\text { Material } \\
\text { Classification }\end{array}$} & \multirow{2}{*}{$\begin{array}{l}\text { Early Occupation } \\
\text { Dugout Floor }\end{array}$} & \multirow{2}{*}{$\begin{array}{l}\text { Mixed Occupation } \\
\text { Surface near } \\
\text { Dugout }\end{array}$} & \multicolumn{3}{|c|}{ Late Occupation } & \multirow[b]{2}{*}{ Totals } \\
\hline & & & BHT 9 & $\begin{array}{l}\text { Surface } \\
\text { near House }\end{array}$ & $\begin{array}{l}\text { Trash Fill } \\
\text { in Dugout }\end{array}$ & \\
\hline Metal & 1 & - & - & - & 94 & 95 \\
\hline Ceramics & - & 3 & - & 2 & 58 & 63 \\
\hline Glass & - & 2 & 1 & 9 & 148 & 160 \\
\hline Rubber & - & - & - & - & 1 & 1 \\
\hline Leather & - & - & - & - & 54 & 54 \\
\hline Bone & 11 & - & - & - & 70 & 81 \\
\hline Shell & - & - & - & - & 1 & 1 \\
\hline Other & $=$ & $=$ & $=$ & $=$ & 2 & 2 \\
\hline Totals: & 12 & 5 & 1 & 11 & 428 & 457 \\
\hline
\end{tabular}

\section{Early Occupation Artifacts}

Eleven bone fragments and one unidentified ferrous metal fragment were recovered from the dugout floor. Three bone fragments were identified as a cow phalanx, a pronghorn phalanx, and a pronghorn magnum. All others are unidentifiable medium-sized mammal bones or unidentifiable fragments.

\section{Mixed Occupation Artifacts}

Three ceramic fragments and two glass container fragments collected from the surface near the dugout may be associated with either the early or the late occupation. One specimen is a green-transfer-painted, scalloped-edge whiteware plate fragment. The other ceramics are a butter churn lid and body fragments of white-glaze coarse earthenware. One specimen is a clear glass inkwell with a broken mouth. It has a distinctive maker's mark on its base: an anchor with a superimposed "H" used by the Anchor Hocking Glass Corporation after the 1938 merger of the Anchor Cap Corporation and the Hocking Glass Company (Toulouse 1971:46-49). The second glass item is a beer-shape brown glass bottle neck fragment with a hand-tooled 1 ip and a brandy-style neck finish (Herskovitz 1978:4-5). It was not machinemade and probably dates prior to the turn of the century when machinemade bottles became popular (Lorrain 1968). 


\section{Late Occupation Artifacts}

Artifacts associated with the late occupation are a 3-mm-thick clear window glass fragment recovered at $0-40 \mathrm{~cm}$ in Backhoe Trench 9, 2 ceramic fragments and 9 complete bottles collected from the surface around the house complex, and 428 artifacts recovered from the dugout depression fill. These artifacts are described by material class.

Metal

Ninety-four metal artifacts were collected from the trash fill in the dugout (Table 10). Not all metal items were collected because unidentifiable metal fragments and tin cans were too numerous. Of the collected specimens, $14 \%$ are unclassified, $59 \%$ are containers and utensils, $15 \%$ are clothing items, and $12 \%$ are structural or furniture related; the container category is underrepresented because only a sample of the tin cans was obtained.

Most of the containers are food related, and some are temporally diagnostic. Holein-cap cans came into use ca. 1820, hole-in-top cans became popular after 1900, and sanitary cans came into use in 1904 (Rock 1984:100-101). These were found in roughly equal proportions, but no sanitary cans were collected. Key-wind can-opening mechanisms came into use in 1866 (Rock 1984:100) and were most popular with flat oblong (sardine-type) cans. One flat oblong can is stamped "BELGIUM," probably indicating an imported food product. A l-gallon can base also contained a food product and is stamped "USE ONE-THIRD LESS THAN BUTTER," "KEEP IN COOL PLACE," and a block "S" and "CO" with the designation "TRADE MARK" underneath. Two fruit jar lids have glass liners embossed "BOYD'S GENUINE PORCELAIN LINED CAP," and the letters "H," "F," "J," and "CO" are found inside a Maltese cross emblem. This is the mark used by the Hero Fruit Jar Company from 1884 to 1900 (Toulouse 1971:249-250).

Machinemade wire nails were invented in the mid 1800s and have been in common use since the end of the nineteenth century (Nelson 1968). The kerosene lantern parts include an iron base and a brass burner of the 4-pronged "sun burner" type illustrated in the 1897 Sears Roebuck Catalogue (Israel 1976). The clock mechanism consists of a brass plate containing iron and brass gears stamped with a mark consisting of "ST" enclosed within a combined diamond, circle, and "U.S.A." below. This mark has not been identified. Two of the metal buttons are embossed with the trade name "BLUE BUCKLE," but this marking has not been identified.

Ceramics

The two ceramic sherds from the house area are undecorated whiteware base fragments from unknown vessel forms. One has an unidentified partial maker's mark consisting of a green floral design. The second has an olive green partial maker's mark identified as the John Maddock and Sons, Royal Vitreous mark used after 1891 (Kovel and Kovel 1953:202).

Fifty-eight ceramic artifacts, representing a minimum of 20 kitchen vessels were recovered from the trash fill in the dugout (Table 11). The most complete vessel is ca. 
TABLE 10

METAL ARTIFACTS RECOVERED FROM TRASH FILL IN THE DUGOUT, 41 GR474

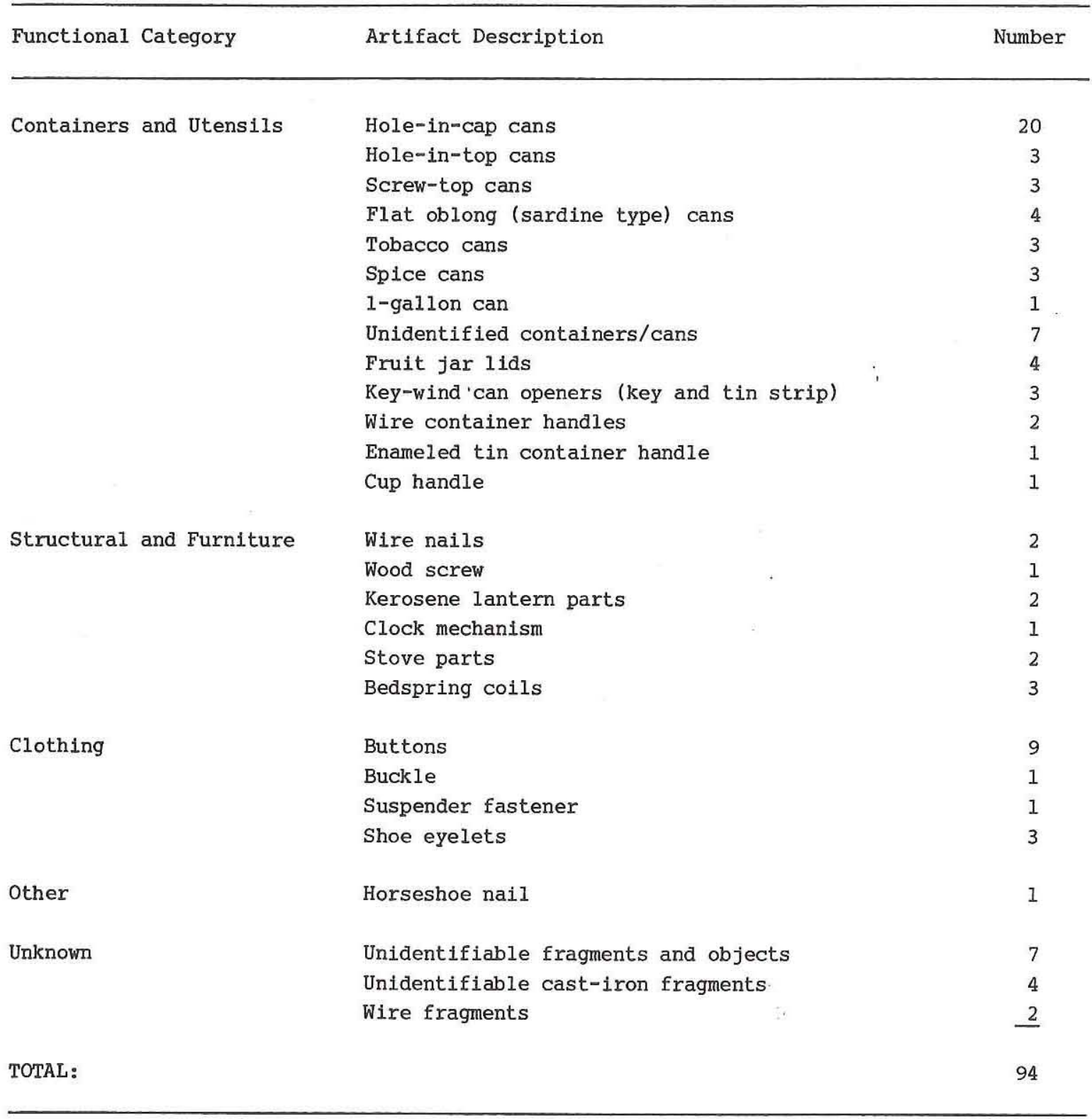

$30 \%$ of a 180-mm-tall and 140-mm-wide pitcher. It is green floral transfer-printed whiteware and has a scalloped rim and an ornate embossed handle with a gold design. The decorations were applied over glaze and are faded. One specimen, an undecorated whiteware base fragment, has a partial maker's mark identified as the John Maddock and Sons, Royal Vitreous crown symbol used in Burslem, England, after 1891 (Kovel and Kovel 1953:202). It is the same mark as that found on a whiteware fragment collected from the house complex. 


\begin{tabular}{|c|c|c|c|c|}
\hline Ware & Decoration & Vessel Forms & $\begin{array}{l}\text { No. of } \\
\text { Sherds }\end{array}$ & $\begin{array}{l}\text { Minimum } \\
\text { No. of } \\
\text { Vessels }\end{array}$ \\
\hline \multirow[t]{3}{*}{ Coarse earthenware } & $\begin{array}{l}\text { Blue glaze exterior/ } \\
\text { white glaze interior }\end{array}$ & Bow1 & 6 & 1 \\
\hline & Yellowish white salt glaze & Bowl, large jar & 21 & 7 \\
\hline & $\begin{array}{l}\text { White salt glaze/Albany } \\
\text { slip }\end{array}$ & Large jar & 1 & 1 \\
\hline \multirow[t]{4}{*}{ Whiteware } & $\begin{array}{l}\text { Green floral transfer } \\
\text { print/gold overglaze, } \\
\text { scalloped rim }\end{array}$ & Small pitcher ; & 1 & 1 \\
\hline & $\begin{array}{l}\text { Green floral transfer } \\
\text { print/embossed, } \\
\text { scalloped rim }\end{array}$ & Plate or bow 1 & 4 & 1 \\
\hline & $\begin{array}{l}\text { Embossed floral pattern/ } \\
\text { scalloped rim }\end{array}$ & se & 7 & 1 \\
\hline & Undecorated & Plate, bowl & 14 & 7 \\
\hline Semiporcelain & Undecorated & Unknown & 4 & 1 \\
\hline TOTALS: & & & 58 & 20 \\
\hline
\end{tabular}

Glass

The nine complete bottles collected from the surface around the house complex were machinemade after ca. 1903 and probably contained medicine, toiletries, liquor, and food products (Table 12). Each has an embossed maker's mark on its base, and some have embossed designations elsewhere on the bottle. Specimen 1 is a screw-top, round prescription shape (Herskovitz 1978:4-5) medicine bottle with the Owens Illinois Glass Company mark used from 1929 to 1954 (Toulouse 1971:403). Other designations include plant "7," year "5," and mold "8." It was most likely manufactured in 1935 or 1945 . Specimen 2 is a cork-seal, beershape, and brandy-finish (Herskovitz 1978:4-5) liquor bottle with the Owens Illinois Glass Company mark used from 1929 to 1954 (Toulouse 1971:403). Other designations include "D23," "G4-6," "ONE QUART," and "FEDERAL LAW FORBIDS SALE OR RE-USE OF THIS BOTTLE." Specimen 3 is a cork-seal, long-necked, crown-finish (Herskovitz 1978:4-5) bottle with the Owens Illinois Glass Company mark used from 1929 to 1954 (Toulouse 1971:403). Other designations include plant " 3 " and mold "9"; the year designation is obliterated by a suction mark. The cork is still in the mouth, and there is a dried, dark brown substance inside, possibly a liquor residue. Specimen 4 is a cork-seal, round prescription shape and finish (Herskovitz 
TABLE 12

ATTRIBUTES OF BOTTLES COLLECTED FROM THE SURFACE, 41 GR474

\begin{tabular}{lccccccc}
\hline & $\begin{array}{l}\text { Exterior } \\
\text { Base } \\
\text { Diameter } \\
(\mathrm{mm})\end{array}$ & $\begin{array}{c}\text { Container } \\
\text { Height } \\
(\mathrm{mm})\end{array}$ & $\begin{array}{c}\text { Neck } \\
\text { Finish } \\
\text { Height } \\
(\mathrm{mm})\end{array}$ & $\begin{array}{c}\text { Interior } \\
\text { Base } \\
\text { Diameter } \\
(\mathrm{mm})\end{array}$ & $\begin{array}{l}\text { Glass } \\
\text { Color }\end{array}$ & $\begin{array}{l}\text { Date of } \\
\text { Manufacture }\end{array}$ & $\begin{array}{l}\text { Probable } \\
\text { Contents }\end{array}$ \\
\hline & & & & & & & \\
1 & 44 & 104 & 21 & 13 & Brown & 1935 or 1945 & Medicine \\
2 & 90 & 272 & 90 & 20 & Clear & $1929-1954$ & Liquor \\
3 & 90 & 299 & 142 & 16 & Clear & $1929-1954$ & Unknown \\
4 & 39 & 92 & 15 & 11 & Brown & 1935 or 1945 & Medicine \\
5 & 28 & 59 & 12 & 11 & Brown & $?$ & Medicine \\
6 & 33 & 76 & 15 & $?$ & Brown & $?$ & Medicine \\
7 & 41 & 87 & 15 & 10 & Brown & 1933 or 1943 & Medicine \\
8 & 90 & 239 & 88 & 16 & Clear & 1943 & Toiletries \\
9 & 62 & 209 & 98 & 19 & Clear & 1945 & Food \\
\hline
\end{tabular}

1978: 4-5) medicine bottle with the Owens Illinois Glass Company mark used from 1929 to 1954 (Toulouse 1971:403). Other designations include plant " 1 ," year "5," mold "1845," and "50 MILS" and "60 MILS" level marks on the sides of the bottle. It was probably manufactured in 1935 or 1945. The cork is still inside the mouth, but the bottle is empty. Specimens 5 and 6 are round prescription shape and finish (Herskovitz 1978:4-5) medicine bottles with unidentified maker's marks: a 5-pointed star inside a circle, surrounded by "FRANKLIN PRODUCTS 1845." Specimen 5 is a cork-seal bottle with "6 cc," "10 cc," and "12 CC" level markings on its side. Specimen 6 has a metal syringe cap with a red rubber seal. Specimen 7 is a cork-seal, round prescription bottle with the Owens Illinois Glass Company mark used from 1929 to 1954 (Toulouse 1971:403). Other designations include plant "7," year "3," mold "1845," and "126." It was probably manufactured in 1933, 1943, or 1953. Specimen 8 is a round crown-finish (Herskovitz 1978:4-5) bottle with the Owens Illinois Glass Company mark used from 1929 to 1954 and the script "Duraglas" label used since 1940 embossed on both sides (Toulouse 1971:403). Other designations include plant "2," year "3," and mold "8." It was probably manufactured in 1943 or 1953 and contained a toiletry product (e.g., mouthwash). Specimen 9 is a round ketchup-type bottle with 16 flat panels and a snap-on cap, possibly a Kork-N-Seal closure (Bender 1986:90-95). It has the Owens Illinois Glass Company mark used from 1929 to 1954 and the script "Duraglas" label used since 1940 (Toulouse 1971:403) on its base. Other designations include plant "12," year "5," mold "5," and "E1635". It was probably manufactured in 1945.

Of the 148 glass artifacts recovered from the trash fill in the dugout, 95\% are containers and utensils (Table 13). Unidentifiable fragments consisted of brown, green, purple, and clear glass. One complete specimen is a clear flat panel bottle measuring $155 \mathrm{~mm}$ tall and $62 \times 37 \mathrm{~mm}$ at the base. It is a union oval shape with a prescription neck finish (Herskovitz 1978:4-5) and is embossed "Parker's," "DRUG STORE," and "FORT WORTH, TEX." The mark "CLG CO." embossed on the base was used by the Carr-Lowrey Glass Company from before 1900 to 1920 (Toulouse 1971:134). 
TABLE 13

GLASS ARTIFACTS RECOVERED FROM TRASH FILL IN THE DUGOUT, 41 GR474

\begin{tabular}{llr}
\hline Functional Category & Artifact Description & Number \\
\hline \multirow{3}{*}{ Containers and Utensils } & Unidentified container fragments & 76 \\
& Complete bottle & 1 \\
& Bottle base and body fragments & 27 \\
& Bottle neck and rim fragments & 16 \\
& Bottle stopper & 14 \\
& Pressed glass fragments & 6 \\
Structural and Furniture & Pressed glass tableware & 1 \\
& Lamp chimney & 4 \\
Clothing & Window glass & 2 \\
TOTAL: & Glass buttons & 148
\end{tabular}

Several base and body fragments have marker's marks or other identifying marks. One bottle has an embossed devil with "PLUTO" and " 3 " on one side; its size and shape suggest that it contained a soft drink. This logo is unidentified but might be a local beverage company trademark. Another bottle has an "A" inside a circle, which could be either the American Glass Works mark used from 1908 to 1935 or the Armstrong Cork Company Glass Division mark used from 1938 to 1969 (Toulouse 1971:22-24). Two bottle bases have the Diamond Glass Company mark used since 1924, which consists of a simple diamond (Toulouse 1971:550). The code numbers "616" and "989" inside the diamond probably designate the contents or bottle characteristics.

The bottle base and body fragments are from several different types of containers. Most are probably food or liquor bottles, but three are square snuff bottle bases, each with two embossed dots. Bottle neck fragments include three screw-top fruit jars, two snuff bottles, three prescription finish panel bottles, two wide-mouth milk bottles, three beer or brandy finish liquor bottles, one crown finish soda pop bottle, and two Kork-N-Seal bottles with closures attached (see Herskovitz 1978:5 for neck finishes). The Kork-N-Seal closure was manufactured from ca. 1911 until the 1960s (Bender 1986:90); the contents of these bottles is unknown.

A bottle stopper of brown glass with a 12-mm-diameter ground glass seal is probably from a medicine bottle or toiletry container. The pressed glass is purple or clear tableware; drinking glasses and pitchers are the only recognizable forms, and the designs are geometric or floral. The lamp chimney is clear glass and probably relates to the kerosene lantern parts (see metal artifacts). The clear window glass fragments are $2.5 \mathrm{~mm}$ thick. 
Rubber

One rubber artifact, a shoe heal and sole, was recovered from the trash fill in the dugout. It is a single-piece, machine-stitched heal and sole which postdates 1850 when rubber was first used in the shoe industry (Anderson 1968:59).

Leather

of the 54 leather artifacts recovered from the trash fill in the dugout, 21 are unidentifiable fragments, and 33 are shoe fragments. The shoe fragments consist of nailed boot or shoe heals, sole fragments, and upper fragments with brass eyelets or eyelet rows. A minimum of 10 shoes is represented. The most complete is a left, ladies high-top, laceup leather shoe with an estimated total length of $225 \mathrm{~mm}$. All of the shoe soles are machine stitched and postdate 1862 (Anderson 1968:64).

Bone and Shell

Seventy bones and bone fragments and a 2-hole shell button were recovered from the trash fill in the dugout. The identifiable elements consist of 19 pheasant, 14 bovid, and 9 rabbit, representing a minimum of 3 pheasants, 1 bovid, and 2 rabbits. No evidence of butchering was noted, but the remains are probably food related.

Other

Two unidentified graphite or carbon rods were recovered from the trash fill in the dugout. One of the rods is complete $(57 \mathrm{~mm}$ long) and has a flattened end with brass screw tighteners for attaching wires. The rods are most likely from batteries.

HISTORIC SITE 41 GR528

Of the 10 artifacts recovered from a general surface collection at 41GR528, 6 are metal, 1 is ceramic, and 3 are glass. Two are distorted lead lumps. A third specimen is a 6.5-mm-diameter expended brass Berdan primer, which measures closest to the .251-inchdiameter Berdan primer (Barnes 1980:318-323). Invented in 1866, the Berdan primer was widely used until after the turn of the century; it has not been manufactured by American companies since the 1920s. Two specimens are square nails, which were generally used until the late 1800s when wire nails became popular (Nelson 1968). The sixth specimen is a holein-cap tin can lid; these were common from the 1820s until the turn of the century (Rock 1984:100-101). The seventh artifact is a reddish brown, 2-mm-thick coarse earthenware fragment, most likely from a pipe bowl. The eighth specimen is a partial glass jar top consisting of six fragments. It is ca. $100 \mathrm{~mm}$ in diameter and is similar to the lightening-type closure patented in the U.S. for jars and bottles in 1882 (Lorrain 1968: 
44). Embossed dates around the edges refer to patent registrations, "FEB 4. 1. 56," "Nov. 4. 62," and "June. 9. 68." The last two artifacts are brown glass bottle fragments. They are 6-10 mm thick and are probably from beer or liquor bottles.

\section{HISTORIC SITE 41 KT 42}

Sixty items were recovered from four contiguous test units in the structure at $41 \mathrm{KT} 42$ (Table 14). The brass cartridge case is a .44- or .45-caliber center-fire and has no base stamp. The body diameter is $12 \mathrm{~mm}$, and the case length is $33 \mathrm{~mm}$. The coarse earthenware sherds may be from a single large jar. The bottle base fragment is from a small, clearglass oval container, possibly a toiletry product. The bottle mouth fragment is a purple glass, tooled lip with a double-bead finish (Herskovitz 1978:5). The hand-tooled lip indicates manufacture prior to 1903 (Lorrain 1968:44), but the function of this bottle is unknown. Machine-cut square nails are not particularly diagnostic; they came into use in the late 1800s and are still used today but were generally more common in the nineteenth century (Nelson 1968).

TABLE 14

HISTORIC ARTIFACTS, 41KT42

\begin{tabular}{|c|c|c|}
\hline Material Classification & Artifact Descriptions & Total \\
\hline \multirow[t]{5}{*}{ Metal } & Unidentifiable fragments & 2 \\
\hline & Wire staples & 18 \\
\hline & Machine-cut square nails & 9 \\
\hline & Container lid & 1 \\
\hline & Brass cartridge case & 1 \\
\hline Ceramic & $\begin{array}{l}\text { Coarse earthenware jar fragments } \\
\text { (Albany slip/salt glaze) }\end{array}$ & 7 \\
\hline \multirow[t]{4}{*}{ Glass } & Unidentifiable fragments, clear & 8 \\
\hline & Unidentifiable fragment, purple & 1 \\
\hline & Bottle base fragment, clear & 1 \\
\hline & Bottle mouth fragment, purple & 1 \\
\hline Hard Rubber & Comb handle fragment & 1 \\
\hline Leather & Unidentifiable fragment & 1 \\
\hline \multirow[t]{3}{*}{ Bone } & Unidentifiable fragment & 1 \\
\hline & Unidentifiable fragment, burned & 1 \\
\hline & Bovid rib fragments & 4 \\
\hline Wood & Unidentifiable fragments & 3 \\
\hline TOTAL: & & $\overline{60}$ \\
\hline
\end{tabular}




\section{DISCUSSION}

Four occupations are represented by the historic artifact assemblages recovered from three sites, 41GR474, 41GR528, and 41KT42. A functional classification of these artifacts is employed to illustrate differences between the artifact assemblages. Nine functional categories are used, and artifacts that cannot be functionally classified are excluded (South 1977:92-102). The Kitchen group consists of artifacts associated with the storage, preparation, and consumption of food, including all ceramics, glassware, and metal containers unless other specific functions could be inferred. Stove parts and liquor and pharmaceutical containers are also included. The Bone group consists of all faunal remains considered to be the by-products of food consumption. The Architectural group consists of artifacts related to structures, including nails, wood screws, wire staples, window glass, and wood fragments. The Furniture group consists of the kerosene lantern, clock, and bed parts. The Arms-related group consists of the cartridge case, primer, and lead lumps. The Clothing group consists of buttons and shoe parts. The Personal group consists of only one artifact, the comb fragment. The Tobacco group consists of snuff bottles, tobacco cans, and a pipe fragment. The Activities group consists of artifacts that, indicate specific special activities and consists of a horseshoe nail and probable battery carbon rods.

The functional classification indicates substantial differences between the artifact assemblages associated with different occupations, in spite of some sampling problems (Table 15). Only one of the samples is of an adequate size to be representative of the range of cultural materials, but some inferences can be made. The early occupation artifacts from the floor of the dugout at 41 GR474 are all in the Bone group except for an unidentified metal fragment. This is not likely the result of differential preservation, and one possible explanation is that small bone fragments might be easier to lose inside a structure than would other types of artifacts. The paucity of artifacts recovered suggests that the dugout occupation was a relatively short one or that the occupants periodically cleaned the floor of debris.

The late occupation artifact assemblage, dominantly from a trash dump located well away from the house at 41GR474, is somewhat skewed because not all of the tin cans were collected, and thus the Kitchen group is probably underrepresented. The recovered artifacts do, however, represent a wide range of functions and indicate a fairly lengthy occupation. The Kitchen and Bone groups dominate ( $82 \%$ ) the assemblage, as would be expected in a household trash dump. The Architecture and Furniture groups are poorly represented, probably due in part to the location of the dump. The Clothing group is well represented, but no Personal group artifacts were recovered. Tobacco-related artifacts were recovered but are not abundant. No Arms-group artifacts were found, and the Activities group is not well represented, perhaps reflecting a relatively unspecialized site function.

The artifact assemblage from 41 GR528 is very small and is undoubtedly skewed because of the amount of relic collecting. A key point, however, is that the Arms and Tobacco groups are well represented for such a small sample and are well represented in other collections from the site (Bryan et al. 1989:624-625). The relative abundance of Arms- and Tobacco-group artifacts indicate a specialized site function.

The assemblage from $41 \mathrm{KT} 42$ is dominated by Architectural-group artifacts, while the Kitchen group is less abundant. This pattern is similar to the frontier artifact pattern resulting from limited access to many types of products (South 1977:146). The Arms 
TABLE 15

FUNCTIONAL CLASSIFICATION OF HISTORIC ARTIFACTS

\begin{tabular}{|c|c|c|c|c|c|c|c|c|}
\hline \multirow{3}{*}{$\begin{array}{l}\text { Functional } \\
\text { Classification* }\end{array}$} & \multicolumn{4}{|c|}{ 41GR474** } & \multicolumn{2}{|c|}{ 41GR528 } & \multicolumn{2}{|c|}{$41 \mathrm{KT} 42$} \\
\hline & Early & Occupation & Late & Occupation & & & & \\
\hline & No. & $\%$ & No. & $\%$ & No. & $\%$ & No. & $\%$ \\
\hline Kitchen & - & - & 264 & 65.0 & 4 & 40.0 & 19 & 33.3 \\
\hline Bone & 11 & 100.0 & 70 & 17.2 & - & - & 6 & 10.5 \\
\hline Architecture & - & - & 8 & 2.0 & 2 & 20.0 & 30 & 52.6 \\
\hline Furniture & - & - & 7 & 1.7 & - & - & - & - \\
\hline Arms & - & - & - & - & 3 & 30.0 & 1 & 1.8 \\
\hline Clothing & - & - & 51 & 12.6 & - & - & - & - \\
\hline Personal & - & - & - & - & - & - & 1 & 1.8 \\
\hline Tobacco & - & - & 3 & 0.7 & 1 & 10.0 & - & - \\
\hline Activities & $=$ & - & 3 & 0.7 & $=$ & - & $=$ & - \\
\hline Totals: & $\overline{11}$ & $\overline{100.0}$ & $\overline{406}$ & $\overline{99.9}$ & $\overline{10}$ & $\overline{100.0}$ & $\overline{57}$ & $\overline{100.0}$ \\
\hline
\end{tabular}

*From South (1977:92-102); functionally unidentified specimens are not included.

**Excludes the mixed occupation assemblage.

category is also represented, and previous investigations recovered other artifacts in this group (Bryan et al. 1989:633-634). This assemblage is somewhat biased, however, in that it consists only of artifacts recovered from excavations at the structure.

Chronologically, the four assemblages reflect the late 1800 s to ca. 1950. No temporally sensitive artifacts are present in the early occupation assemblage at 41GR474. At 41GR528, a glass artifact with patent dates, the Berdan primer, and the tin cans indicate a probable late 1800 s assemblage. The assemblage at $41 \mathrm{KT} 42$ includes only one temporally sensitive artifact, a tooled-lip bottle fragment which indicates a pre-1900 manufacture date. Only the late occupation at 41GR474 contains a substantial number of temporally sensitive artifacts. Diagnostic artifacts collected from the house area range in manufacture date from 1891 to 1954, but the bottles (see Table 12) are particularly diagnostic of the 1929-1945 era. The trash fill in the dugout contained a range of tin cans which were in common use from the mid $1800 \mathrm{~s}$ to the present. Of the fruit jar lids recovered, two were manufactured between 1884 and 1900, and a ceramic maker's mark indicates a manufacture date of 1891 or later. Two Kork-N-Seal closures on bottle necks indicate manufacture between 1911 and the 1960s. While some artifacts were manufactured prior to the turn of the century, the majority of artifacts were made or were in common use after 1900. The late occupation artifact assemblage dates from before 1900 to ca. 1945. 


\section{REFERENCES CITED}

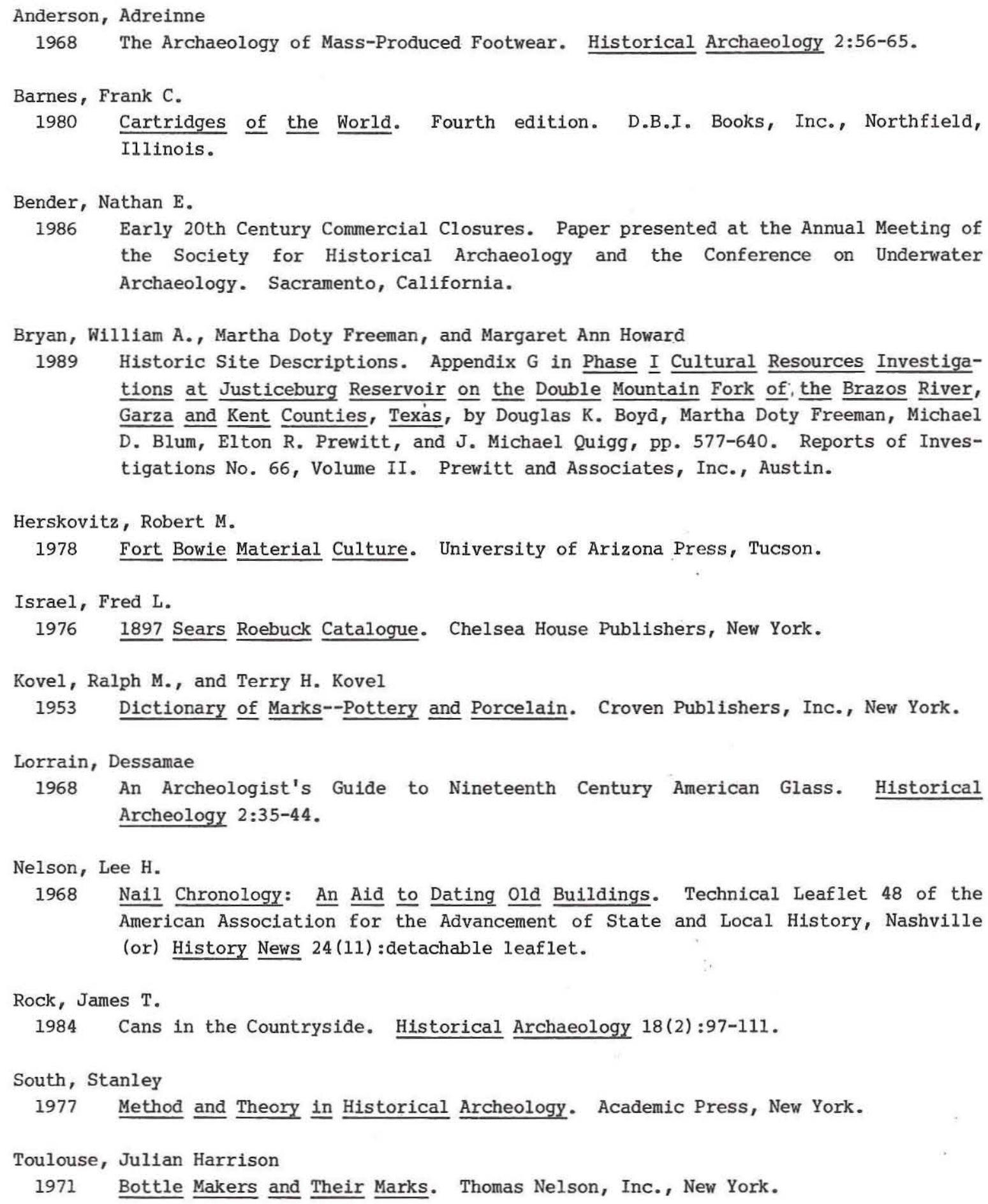
tions at Justiceburg Reservoir on the Double Mountain Fork of; the Brazos River, Garza and Kent Counties, Texás, by Douglas K. Boyd, Martha Doty Freeman, Michael D. Blum, Elton R. Prewitt, and J. Michael Quigg, pp. 577-640. Reports of Investigations No. 66, Volume II. Prewitt and Associates, Inc., Austin.

Herskovitz, Robert M.

1978 Fort Bowie Material Culture. University of Arizona Press, Tucson.

Israel, Fred L.

19761897 Sears Roebuck Catalogue. Chelsea House Publishers, New York.

Kovel, Ralph M., and Terry H. Kovel

1953 Dictionary of Marks--Pottery and Porcelain. Croven Publishers, Inc., New York.

Lorrain, Dessamae

1968 An Archeologist's Guide to Nineteenth Century American Glass. Historical Archeology 2:35-44.

Nelson, Lee $\mathrm{H}$.

1968 Nail Chronology: An Aid to Dating Old Buildings. Technical Leaflet 48 of the American Association for the Advancement of State and Local History, Nashville (or) History News 24 (11) :detachable leaflet.

Rock, James T.

1984 Cans in the Countryside. Historical Archaeology 18(2):97-111.

South, Stanley

1977 Method and Theory in Historical Archeology. Academic Press, New York.

Toulouse, Julian Harrison

1971 Bottle Makers and Their Marks. Thomas Nelson, Inc., New York. 


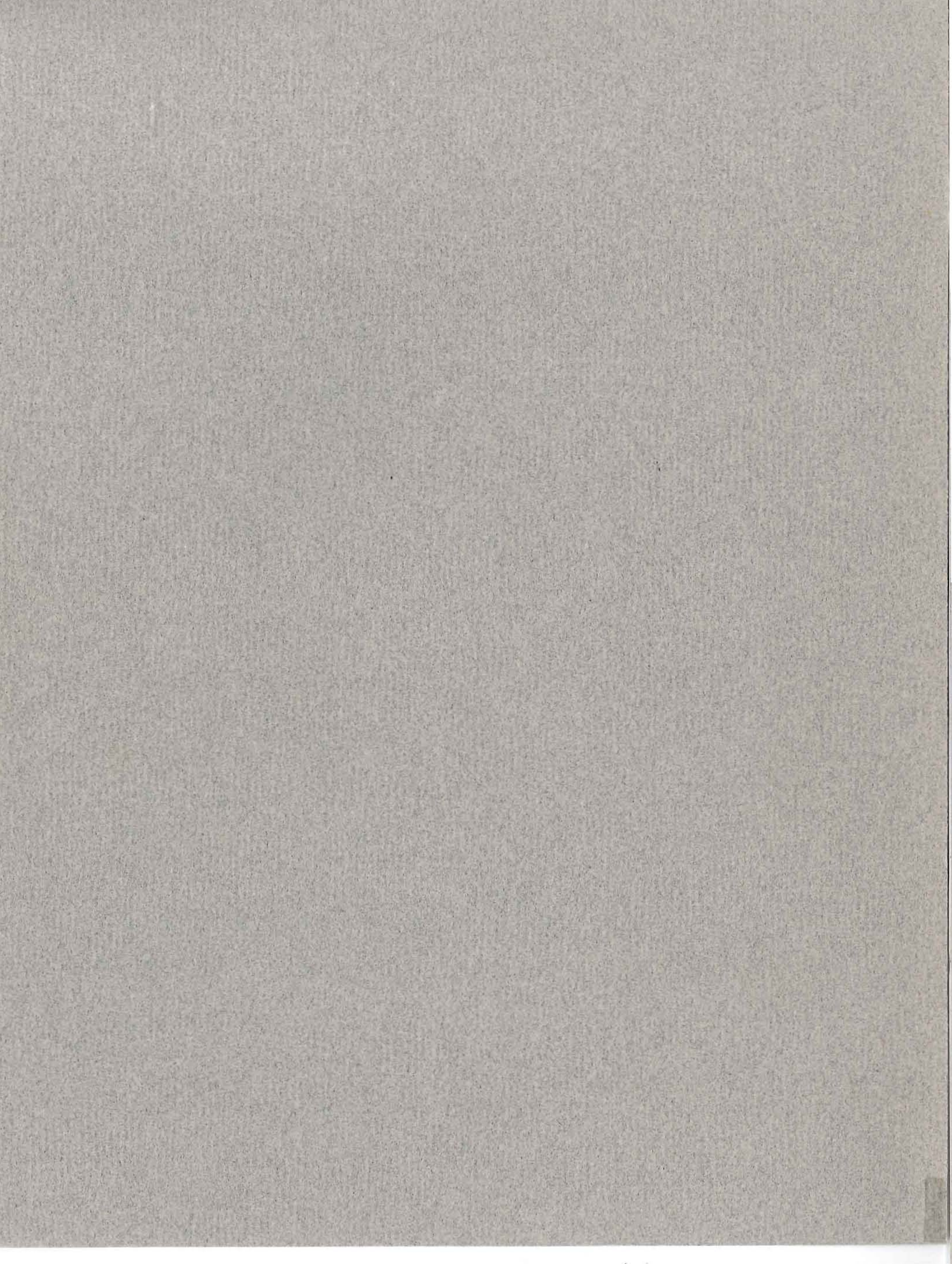

